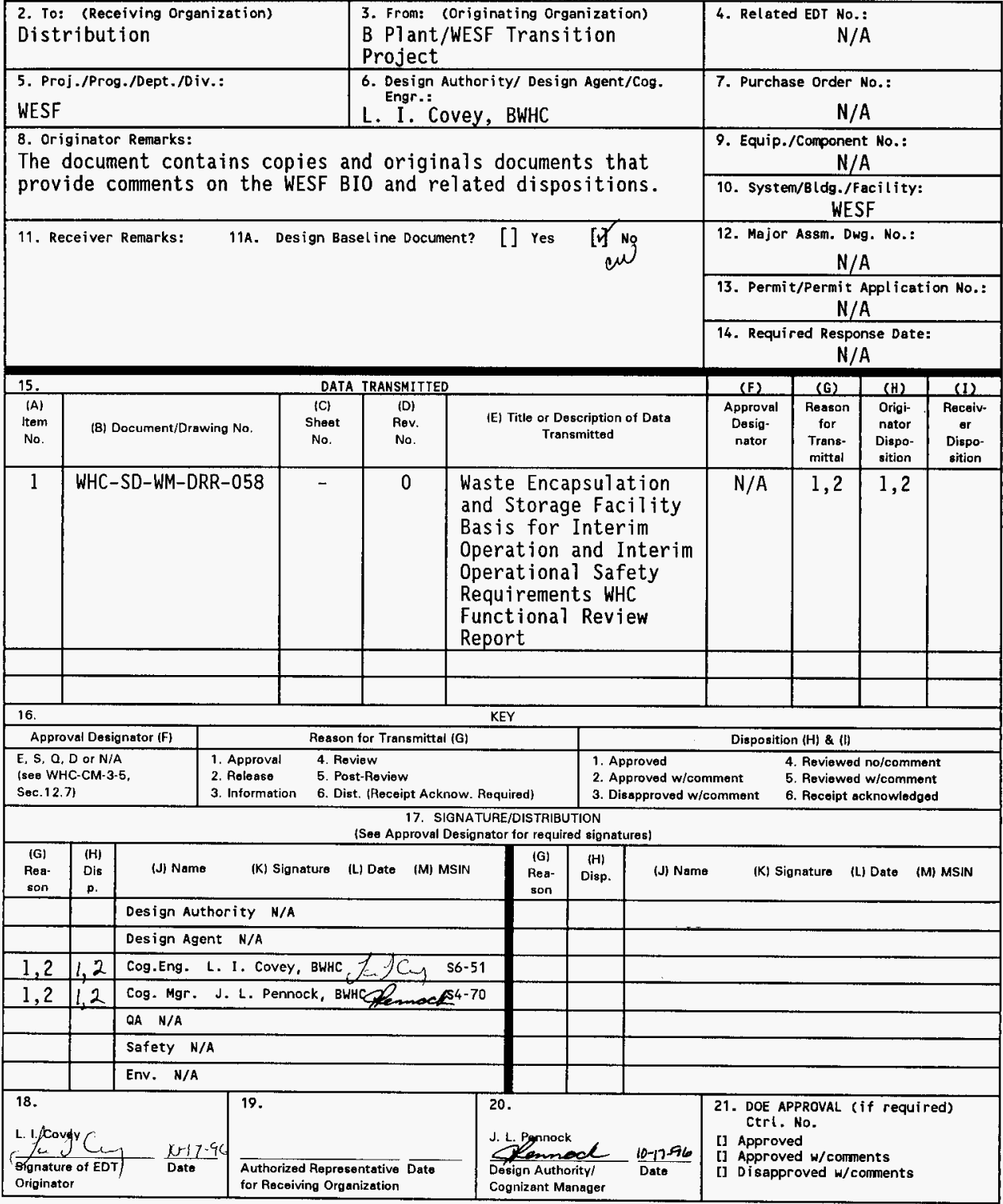

BD-7400-172-2(05/96) GEF097 


\title{
Waste Encapsulation and Storage Facility Basis for Interim Operation and Interim Operational Safety Requirements WHC Functional Review Report
}

\section{I. Covey}

BNW Hanford Company, Richland, WA 99352

U.S. Department of Energy Contract DE-AC06-87RL10930

\author{
EDT/ECN: $616276 \quad$ UC: 510 \\ Org Code: EJ4E3000 Charge Code: KW4C5 \\ B\&R Code: EW3135090 Total Pages: 207
}

Key Words: Review comment record, Basis for Interim Operation, Interim Operational Safety Requirements

Abstract: The document contains the comments provided by WHC reviewers on the WESF BIO and IOSRs.

IRADEMARK DISCLAIMER. Reference herein to any specific commercial product, process, or service by trade name, trademark, manufacturer, or otherwise, does not necessarily constitute or imply its endorsement, recommendation, or favoring by the United States Government or any agency thereof or its contractors or subcontractors.

Printed in the United States of America. To obtain copies of this document, contact: WMC/BCS Document Control Services, P.O. Box 1970, Mailstop H6-08, Richland WA 99352, Phone (509) 372-2420; Fax (509) 376-4989.
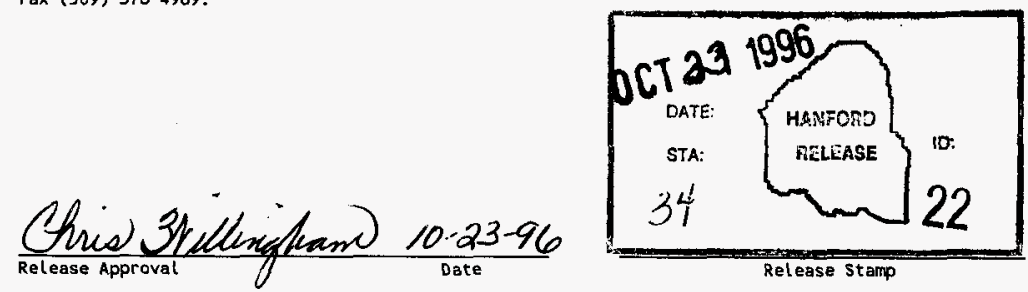

Approved for Public Release 
WHC-SD-WM-DRR-058 Rev. 0

WASTE ENCAPSULATION AND STORAGE FACILITY (WESF)

BASIS FOR INTERIM OPERATION (BIO) and

INTERIM OPERATIONAL SAFETY REQUIREMENTS (IOSR)

WHC FUNCTIONAL REVIEW REPORT

L. I. Covey

October 1996 
WHC-SD-WM-DRR-058 Rev. 0

This page intentionally left blank. 
WHC-SD-WM-DRR-058 Rev. 0

\section{CONTENTS}

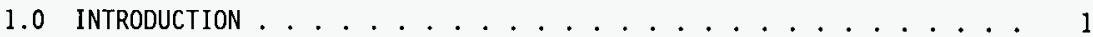

2.0 FUnCTIONAL REVIEW ...................... 1

2.1 REVIEWERS ......................... 1

2.2 REVIEW PROCESS . . . . . . . . . . . . . . . 3

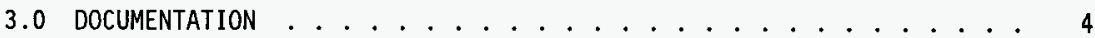

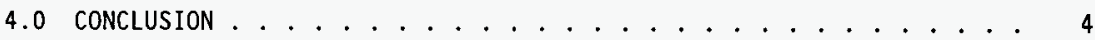

APPENDIX A Closed Functional Review RCRS ............. A-1

APPENDIX B Closed Senior Analyst Advisory Group (SAAG) Review RCRs . . . B-1

APPENDIX C Closed Pacific Northwest National Laboratories Review RCRs . . C-1

APPENDIX D Checklist and RCR for the Independent Technical Review . . . D-1

APPENDIX E Hanford Environmental Dose Overview Panel Review Checklist

for Radiological and Nonradiological Release Calculations . . E-1

APPENDIX F Safety and Environmental Advisory Council, Transition Facility

Subcouncil Review RCRs ............. F-1 
WHC-SD-WM-DRR-058 Rev. 0

This page intentionally left blank. 


\author{
WHC-SD-WM-DRR-058 Rev. 0 \\ WASTE ENCAPSULATION AND STORAGE FACILITY (WESF) \\ BASIS FOR INTERIM OPERATION (BIO) and \\ INTERIM OPERATIONAL SAFETY REQUIREMENTS (IOSR) \\ WHC FUNCTIONAL REVIEW REPORT
}

\title{
1.0 INTRODUCTION
}

This report documents the completion of the Westinghouse Hanford Company (WHC) functional review of the Waste Encapsulation Storage Facility Basis for Interim Operation, WHC-SD-WM-BIO-002, Rev. 0 (BIO) and the Interim Operational Safety Requirements, WHC-SD-WM-IOSR-001, Rev. 0 (IOSR). The WHC functional review of the $B I O$ and the IOSR was conducted during the period from July 23, 1996 to September 26, 1996. Other formal reviews were conducted during the development of the documents as indicated below.

The document was reviewed by WHC personnel in Nuclear Safety, Quality Assurance, Waste Encapsulation and Storage Facility (WESF) operations personnel and WESF technical support personnel. Formal comments on the BI0 and the IOSR were recorded on Review Comment Records (RCRs) in accordance with current WHC procedures. Following the review, comments were dispositioned, approved, and incorporated into the text of the document. Other comments were generated in check 1 ists and meeting minutes.

This report details the functional review process, the reviewers involved, and the disposition and incorporation of comments. Chapter 2.0 provides a description of the functional review process. Appendix $A$ through $F$ provide copies of the closed RCRs, checklists and meeting minutes. The first document listed in this report was originally sent out as an Interim Safety Basis (ISB) document but during the reviews, the document was changed to BIO. Therefore, any data referencing WHC-SD-WM-ISB-009 is actually referring to WHC-SD-WM-BIO-002.

\subsection{FUHCTIONAL REVIEW}

\subsection{IDENTIFICATION OF BIO AND IOSR REVIEWERS}

\subsubsection{Functional Reviewers}

The following is a list of the WHC reviewers that performed the functional review of the WESF BIO and the WESF IOSR.
Name
T. G. Beam
D. D. Beers
R. E. Broz
L. I. Covey
T. Gainey
M. A. Hill

\section{Function}

Waste Management, Technical Support Group Radiation Protection, Technical Support Group Emergency Preparedness WESF Basel ine Program Control Capsule Management Team Quality Assurance, Technical Support Group 
WHC-SD-WM-DRR-058 Rev. 0
D. W. Mertz
S. K. Meyer
K. A. Jennings-Mi11s
J. L. Pennock
G. L. Rensink
S. R. Stark
M. K. Ullah
K. J. Way
R. A. Wilson

Fire Protection

Emergency Preparedness
WESF Basel ine Program Control
WESF Management
Maintenance
Training, Technical Support Group
Nuclear Safety
Hazardous Material, Technical Support
Group
Hazardous Material, Technical Support
Group

\subsubsection{Senior Analyst Advisory Group (SAAG) Reviewers}

The SAAG is chartered by the WHC Safety Analysis and Nuclear Engineering group, reviewed the document during the development of the draft on three occasions. The list of reviewers is provided below.

$\begin{array}{ll}\text { Name } & \text { Function } \\ \text { Crowe, R. D. } & \text { Safety Analys is } \\ \text { Kummerer, M. } & \text { Safety Analys is } \\ \text { Leach, D. S. } & \text { Safety Analys is } \\ \text { Marusich. R. M. } & \text { Safety Analys is } \\ \text { Porten, D. R. } & \text { Safety Analys is } \\ \text { Ramble, A. L. } & \text { Safety Analys is } \\ \text { Smith, Dean } & \text { Safety Analysis }\end{array}$

\subsubsection{Pacific Northwest National Laboratory (PNNL) Reviewers}

PNNL provided an independent review of Chapter 3, Hazard and Accident Analysis of the BIO. The following is a list of names of the PNNL reviewers that provided comments.

Name

K. L. Bohl ander

P. M. Daling

R H Galluci

Y. Liu

\section{Function}

Risk and Safety Analysis

Risk and Safety Analysis

Risk and Safety Analysis

Thermal Analysis

\subsubsection{Safety and Environmental Advisory Committee, (SEAC), Facility Transition Subcouncil Reviewers.}

The BIO and IOSR documents were reviewed by members of the SEAC, Facility Transition Subcouncil. The names of the members that reviewed the BIO are listed below:

Name

Robert J. Cash

Donna M. Busche

Richard G. Cowan 
Ralph D. Crowe

Joseph P. Estrellado, Jr

Don J. Hart

Eugene J. Kosiancic

Patricia L. Lintho

Robert H. Meichle

Allen B. Webb

\subsubsection{Hanford Environmental Dose Overview Panel (HEDOP) Reviewer}

Dave Himes of Safety Analysis and Nuclear Engineering completed a HEDOP Review Checklist to confirm the adequacy of the radiological and nonradiological release calculations provided in Chapter 3 , Hazards and Accident Analysis.

\subsubsection{Independent Technical Reviewer}

H. J. Goldberg of Safety Analys is and Nuclear Engineering completed a Checklist for an Independent Technical Review to confirm the adequacy of the information provided in Chapter 3, Hazards and Accident Analys is.

\subsection{REVIEW PROCESS}

A Project Plan was developed at the beginning of the project which identified the scope, schedule and specific individual resources required for the development of and review of the draft B1O and draft IOSR. The scope of the review process included a WHC functional review, an independent PNNL review and a subsequent review by the SEAC, Facility Transition Subcouncil. other reviews included the HEDOP and the WHC Independent Review Checklist. Chapter authors were assigned to develop draft chapters and provide dispositions to reviewers with subsequent revisions to their assigned chapters.

A1l functional reviewers were requested to submit comments on the WHC Review Comment Record form to the assigned chapter author. Hard copies of the draft document were delivered to functional review participants on July 23, 1996. Electronic draft copies of the BIO and IOSRs were also distributed via the cc:mail. The electronic drafts provided a mechanism for timely transmission, between the RCR commentor and chapter author, of document revisions resulting from dispositions to RCR comments. The author obtained written concurrence and closure from the reviewers for the recommended RCR dispositions and chapter revisions. In order to expedite closure of the RCR document the concurrence was obtained via Cc:mail and then hardcopy RCRs were processed at a later date. The functional review process was completed September 26, 1996. The closed out RCRs from this functional review are included in this report as Appendix $A$.

The SAAG conducted three reviews of Chapter 3 and provided meeting minutes reflecting recommendations to the chapter author. The meeting minutes are included in Appendix $B$ of this report.

The PNNL review of Chapter 3, Hazards and Accident Analysis was completed September 17, 1996. The PNNL reviewers provided comments on the WHC 
Review Comment Record form to the assigned chapter author. The RCRs for the PNNL review are included in this report in Appendix $C$.

The Checklist for Independent Technical Review on Chapter 3 was completed August 20, 1996. This review is used to confirm the adequacy and completeness of the assumptions, input data and resource data used in the chapter. The check list is included in the report in Appendix $D$.

The HEDOP Review Check 1 ist was completed October 1,1996 . The checklist confirms that calculations, codes and input/output are adequate. The check list is included in this report in Appendix $E$.

The SEAC, Facility Transition Subcouncil is assigned to support the facility transition program division by reviewing major documentation and activities affecting safety or environmental policy and for advising program division management of the results of the reviews. The SEAC subcouncil review is a regular part of the process for transmission of the BIO to DOE-RL. The review occurred after completion of the functional review and sign off by applicable functional reviewers. The comments provided by the subcouncil and the related dispositions are in Appendix $F$ of this report.

Other informal reviews were conducted just prior to sending the document to RL to ensure consistency between chapters relative to system descriptions, assumptions and outcomes.

\subsection{DOCUMENTATION}

A11 formal review comments were recorded on RCR forms, meeting minutes or check lists. The functional reviewers, PNNL reviewers and the independent technical reviewer prepared an RCR form with comments. The SAAG committee documented comments in meeting minutes and the HEDOP review was documented on a check list. The RCR form is used to describe the reviewers comments and describe the disposition to the comment. This provided a logical and traceable path for revisions to the document as a result of reviewer comments.

\subsection{CONCLUSION}

This report documents the formal functional review of the WESF BIO. The inhouse review comments have been given dispositions and subsequent revisions have been incorporated into the document, as required. The completion of this review report officially documents and closes the WESF functional review. 
WHC-SD-WM-DRR-058 Rev. 0

APPENDIX A

Closed Functional Review RCRS

A- $\mathbf{i}$ 
WHC-SD-WM-DRR-058 Rev. 0

This page intentionally left blank. 


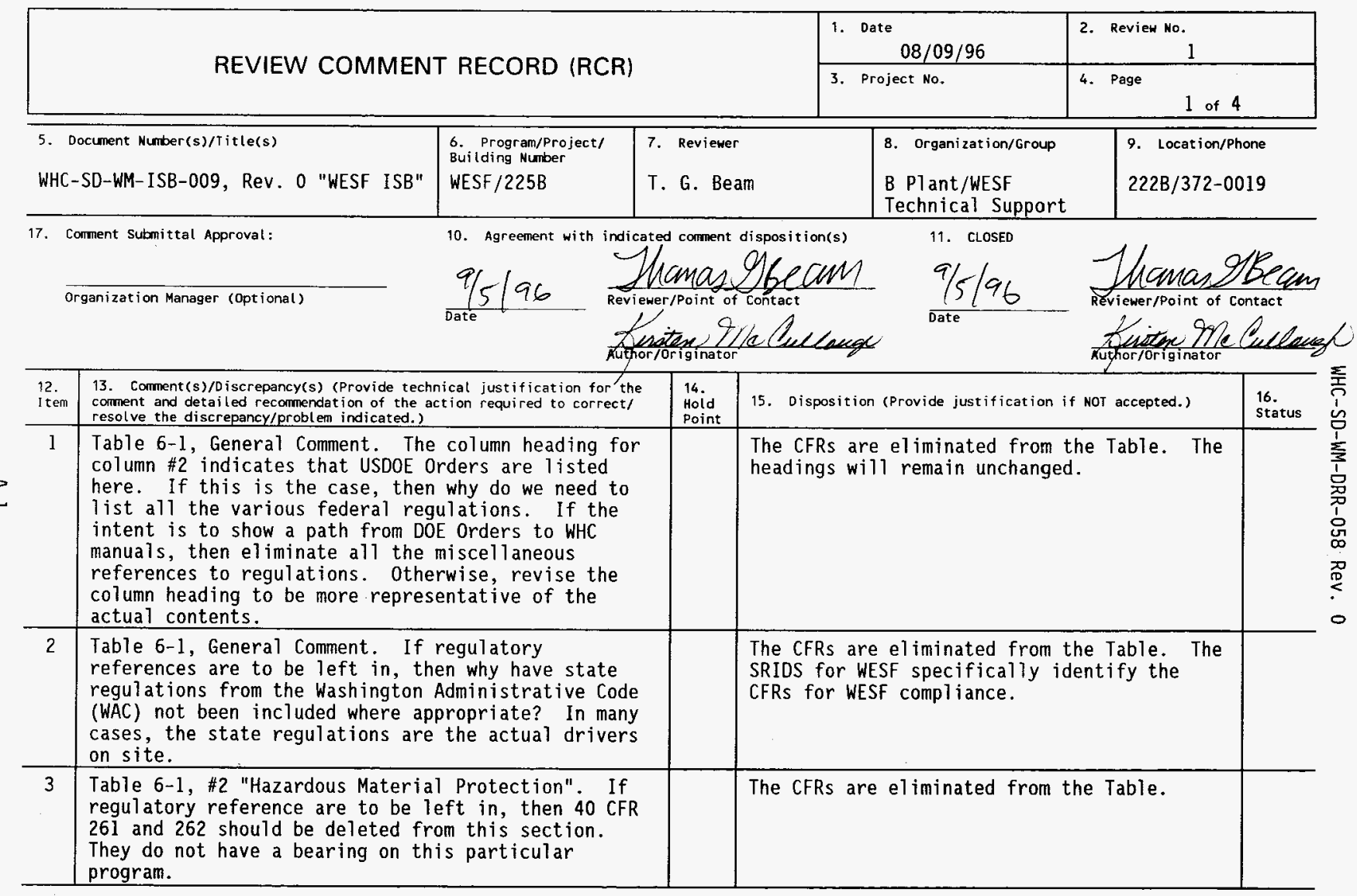




\begin{tabular}{|l|l|l|l|}
\hline \multirow{2}{*}{ REVIEW COMMENT RECORD (RCR) } & $\begin{array}{l}\text { 1. Date } \\
08 / 09 / 96\end{array}$ & Review No. \\
\cline { 2 - 3 } & 3. Project No. & 4. Page \\
\hline
\end{tabular}

\begin{tabular}{|c|c|c|c|c|}
\hline $\begin{array}{l}12 . \\
\text { item }\end{array}$ & $\begin{array}{l}\text { 13. Comment(s)/Discrepancy(s) (Provide technical justification for the } \\
\text { comment and detailed recommendat ion of the action required to correct/ } \\
\text { resolve the discrepancy/problem indicated.) }\end{array}$ & $\begin{array}{l}14 . \\
\text { Hoid } \\
\text { Point } \\
\end{array}$ & 15. Disposition (Provide justification if NOT accepted.) & $\begin{array}{l}16 . \\
\text { Status }\end{array}$ \\
\hline 4 & $\begin{array}{l}\text { Table 6-1, \#1 "Radiation Protection". Should WHC- } \\
\text { CM-4-9 "Radiological Design" be included in column } 3 \\
\text { with the other WHC manuals? }\end{array}$ & & $\begin{array}{l}\text { The Radiological Design Manual is } \\
\text { eliminated. }\end{array}$ & \\
\hline 5 & $\begin{array}{l}\text { Table 6-1, \#2 "HazMat Protection". Column } 3 \text { lists } \\
\text { both WHC-CM-1-11 and } 4-40 \text { as Industrial Hygiene } \\
\text { Manual. Check that these are the appropriate titles } \\
\text { and revise as appropriate. In addition, I am } \\
\text { confused as to how WHC-CM-1-4, 1-8, 3-5, and } 4-2 \text { fit } \\
\text { into this particular program. Confirm that they } \\
\text { indeed do belong here and revise as appropriate. }\end{array}$ & & Hlan shows the same title for both manuals. & \\
\hline 6 & $\begin{array}{l}\text { Table } 6-1 \text {, \#3 "Radioactive and Hazardous Waste } \\
\text { Management". If regulatory references are to be } \\
\text { left in, then } 40 \text { CFR } 260 \text { and } 40 \text { CFR } 262 \text { should be } \\
\text { added to the } 1 \text { ist. } 40 \text { CFR } 264 \text { should be deleted } \\
\text { since it is not applicable to WESF at this time. }\end{array}$ & & CFRs are eliminated from the table. & \\
\hline 7 & $\begin{array}{l}\text { Table 6-1, \#3. I believe that WHC-CM-5-16 "Solid } \\
\text { Waste Management" has been canceled. Confirm and } \\
\text { revise as appropriate. In addition, I don't think } \\
\text { that WHC-CM-4-9 "Rad Design" belongs in this } \\
\text { section. }\end{array}$ & & $\begin{array}{l}\text { WHC-CM- } 5-16 \text { is deleted from the H-Lan and is } \\
\text { deleted from the table. }\end{array}$ & \\
\hline 8 & $\begin{array}{l}\text { Section } 6.2 \text {, paragraph } 2 \text {. It is referenced that } \\
\text { hazardous materials at WESF are identified in Table } \\
3.3 .2 .1-1 \text {. Is it really necessary to specifically } \\
1 \text { ist all the hazardous materials? This would } \\
\text { require a revision to the ISB anytime these products } \\
\text { changed. Perhaps it would be more beneficial to } \\
\text { list types or categories of materials and their } \\
\text { associated hazardous. We could then reference the } \\
\text { appropriate MSDS or similar info as necessary. }\end{array}$ & & $\begin{array}{l}\text { Table } 3.3 .2 .1-1 \text { summarizes the locations, } \\
\text { quantities, and forms of the hazards } \\
\text { ident ified for WESF for the purposes of } \\
\text { identifying potential accidents and the } \\
\text { material that would be involved. Attached } \\
\text { to this RCR is the } 7 / 23 / 96 \text { version of the } \\
\text { table. } \\
\text { Changes to the ISB will be addressed through } \\
\text { the USQ screening process and document } \\
\text { changes made according to the outcome of the } \\
\text { screening. }\end{array}$ & \\
\hline
\end{tabular}




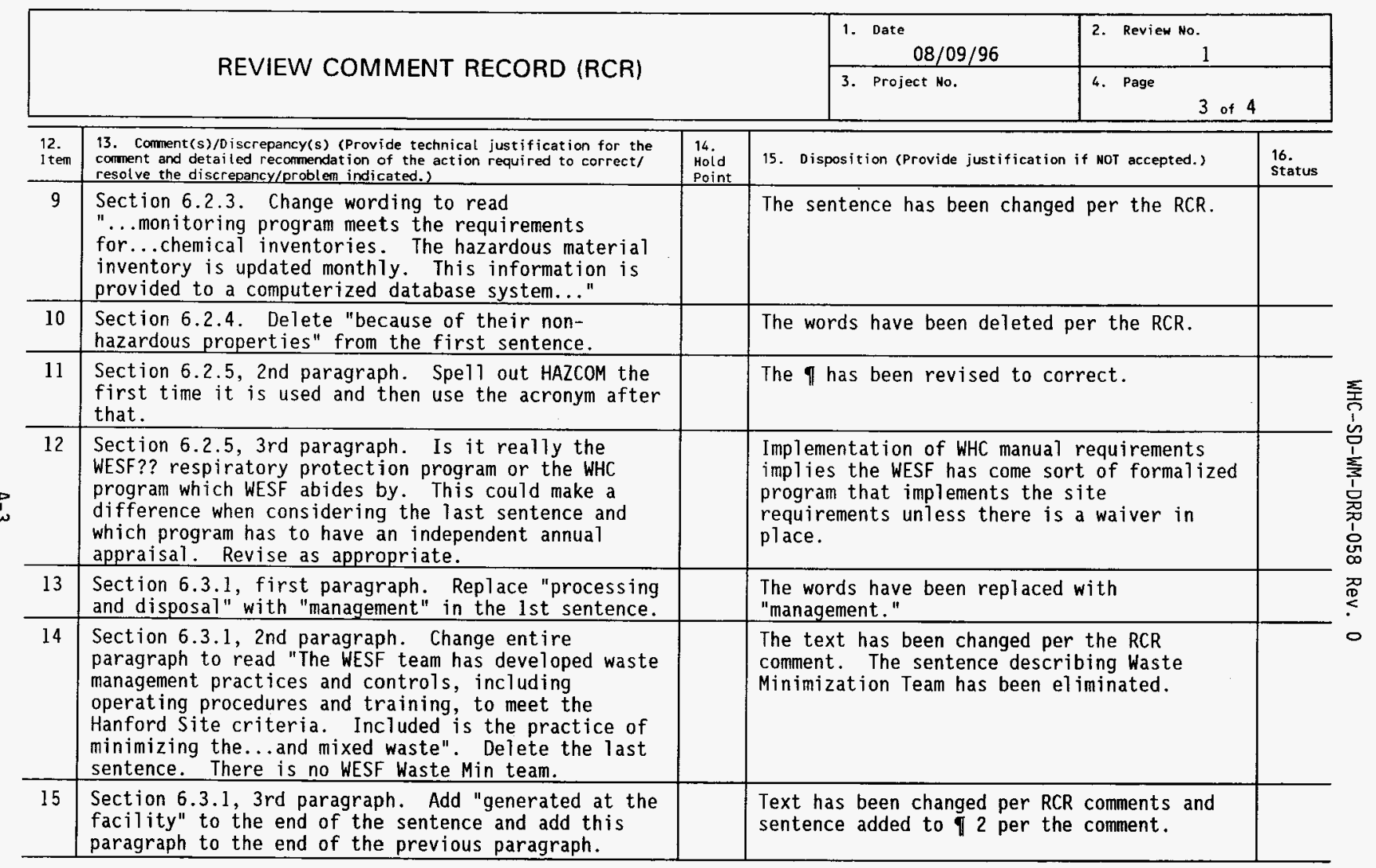




\begin{tabular}{|c|c|c|}
\hline \multirow{2}{*}{ REVIEW COMMENT RECORD (RCR) } & $\begin{array}{l}\text { 1. Date } \\
08 / 09 / 96 \\
\end{array}$ & $\begin{array}{r}\text { 2. Review No. } \\
1\end{array}$ \\
\hline & 3. Project No. & 4. Page \\
\hline
\end{tabular}

\begin{tabular}{|c|c|c|c|c|}
\hline $\begin{array}{l}12 . \\
\text { I tem }\end{array}$ & $\begin{array}{l}\text { 13. Corment(s)/Discrepancy(s) (Provide technical justification for the } \\
\text { comment and detailed recomnendation of the action required to correct/ } \\
\text { resolve the discrepancy/problem indicated.) }\end{array}$ & $\begin{array}{l}14 . \\
\text { Hoid } \\
\text { Point }\end{array}$ & 15. Disposition (Provide justification if NOT accepted.) & $\begin{array}{l}16 . \\
\text { status }\end{array}$ \\
\hline 16 & $\begin{array}{l}\text { Section } 6.3 .2 \text {, lst paragraph. Sections } 2.4 \text { and } 2.6 \\
\text { are referenced as having a description of the waste } \\
\text { sources at WESF. I cannot review these for } \\
\text { completeness and accuracy until I have a copy of } \\
\text { these sections. }\end{array}$ & & $\begin{array}{l}\text { Section } 2.4 \text { and } 2.6 \text { have been forwarded by } \\
\text { cc: amil for review. No change to the text. }\end{array}$ & \\
\hline 17 & $\begin{array}{l}\text { Section } 6.3 .2 \text {, 2nd paragraph. Delete the word } \\
\text { "Currently," from the 2nd sentence. Change "for } \\
\text { storage of" to "to package". Delete the words } \\
\text { "solid waste" inside the parentheses. }\end{array}$ & & Text has been changed per the RCR comment. & \\
\hline 18 & $\begin{array}{l}\text { Section } 6.3 .2 \text {, 2nd paragraph. Move the last } \\
\text { sentence and place at the beginning of the next } \\
\text { paragraph. }\end{array}$ & & Sentence has been moved per the RCR comment. & \\
\hline 19 & $\begin{array}{l}\text { Section } 6.3 .2 \text {, 3rd paragraph. The last sentence is } \\
\text { not correct. Radioactive } 1 \text { iquid does not drain to } \\
\text { the B Plant process sewer. It "discharges" into the } \\
\text { B Plant tank systems in the } 221-B \text { canyon. This } \\
\text { paragraph should probably be reviewed by someone at } \\
\text { WESF who is intimately familiar with the system and } \\
\text { can make sure the details are correct. }\end{array}$ & & $\begin{array}{l}\text { The last sentence in the } 1 \text { is deleted. A } \\
\text { comparison was made to the current version } \\
\text { of the Chapter 2, Facility Description and } \\
\text { it no longer describes the system. }\end{array}$ & \\
\hline & & & & \\
\hline & & & & \\
\hline
\end{tabular}




\section{REVIEW COMMENT RECORD (RCR)}

\begin{tabular}{|l|l|}
\hline 1. Date $08 / 09 / 96$ & 2. Review No. \\
\hline 3. Project No. & 4. Page 5 of 4 \\
\hline
\end{tabular}

Attachment to Tom Beam RCR, 8/09/96

Table 3.3.2.1-1. WESF Hazard Identification Results (3 Sheets)

\begin{tabular}{|c|c|c|c|c|c|}
\hline Hazard & Location & Quantity & form & Remarks & Ref. \\
\hline \multirow[t]{7}{*}{$\begin{array}{l}\text { Radioactiv } \\
\text { e material }\end{array}$} & $\begin{array}{l}\text { Pool } \\
\text { cells }\end{array}$ & $52.05 \mathrm{MCi}{ }^{137} \mathrm{Cs}$ & $\begin{array}{l}\text { cesium chloride, } \\
\text { doubly encapsulated }\end{array}$ & \multirow{2}{*}{$\begin{array}{l}\text { This is the total } \\
\text { uncut cesium and } \\
\text { stront ium capsule } \\
\text { inventory excluding } \\
\text { the } 12 \text { capsules } \\
\text { current ly held in the } \\
324 \text { building. }\end{array}$} & \multirow[t]{2}{*}{$\begin{array}{l}\text { Hey } \\
1996\end{array}$} \\
\hline & & $22.58 \mathrm{MCi}{ }^{90} \mathrm{Sr}$ & $\begin{array}{l}\text { stront ium fluor ide, } \\
\text { doubly encapsulated }\end{array}$ & & \\
\hline & A Cell & $137_{\mathrm{Cs}}^{000 \mathrm{ci}}{ }^{90} \mathrm{Sr}$ or & $\begin{array}{l}208-L(55-g a l) \text { steel } \\
\text { drums of contaminated } \\
\text { solid waste }\end{array}$ & & $\begin{array}{l}\text { Snith } \\
1995\end{array}$ \\
\hline & B Cell & ${ }^{60}{ }_{\mathrm{Sr}}^{\mathrm{kCi}}{ }^{137} \mathrm{Cs}$ and $20 \mathrm{kCi}$ & $\begin{array}{l}\text { stront ium fluoride, } \\
\text { contamination on } \\
\text { equipment, waste, and } \\
\text { surfaces }\end{array}$ & & $\begin{array}{l}\text { Brehm } \\
1996\end{array}$ \\
\hline & C Cell & ${ }_{90} \mathrm{kCi}{ }_{\mathrm{Sr}}^{137} \mathrm{Cs}$ and $20 \mathrm{kCi}$ & $\begin{array}{l}\text { strontium fluoride, } \\
\text { contamination on } \\
\text { equipment, waste, and } \\
\text { surfaces }\end{array}$ & & $\begin{array}{l}\text { 8rehm } \\
1996\end{array}$ \\
\hline & $\begin{array}{l}\text { D/E } \\
\text { Cells }\end{array}$ & $20 \mathrm{kCi}{ }^{137} \mathrm{Cs}$ & $\begin{array}{l}\text { cesium chloride, } \\
\text { contamination on } \\
\text { equipment, waste and } \\
\text { surfaces }\end{array}$ & & $\begin{array}{l}\text { Brehm } \\
1996\end{array}$ \\
\hline & F Cell & $435 \mathrm{~kW}$ (i.e. $940 \mathrm{kCi}$ & $\begin{array}{l}\text { encapsulated cesium } \\
\text { chloride in suspect or } \\
\text { single capsules }\end{array}$ & $\begin{array}{l}\text { Since the capsules in } \\
F \text { Cell are suspect, } \\
\text { the first conf inement } \\
\text { boundary is considered } \\
\text { to be F Cell. Minimum } \\
20 \mathrm{~cm}(7.9 \text { in.) } \\
\text { capsule to surface } \\
\text { distance. }\end{array}$ & $\begin{array}{l}\text { FAI } / 9 \\
6-25\end{array}$ \\
\hline
\end{tabular}




\section{REVIEW COMMENT RECORD (RCR)}

\begin{tabular}{|l|l|}
\hline $\begin{array}{l}\text { 1. Date } \\
08 / 09 / 96\end{array}$ & 2. Review No. \\
\hline 3. Project No. & 4. Page \\
& \\
\end{tabular}

Table 3.3.2.1-1. WESF Hazard Identification Results (3 Sheets)

\begin{tabular}{|c|c|c|c|c|c|}
\hline \multirow[t]{5}{*}{ Hazard } & Location & Quantity & Form & Remarks & Ref. \\
\hline & $\begin{array}{l}k-3 \\
\text { exhaust } \\
\text { duct }\end{array}$ & $\begin{array}{l}5.1 \\
\mathrm{kCi}\end{array}{ }^{58 i_{\mathrm{Sr}}^{137} \mathrm{Cs} \text { or } 200}$ & $\begin{array}{l}\text { Cesium chloride and } \\
\text { strontium fluoride } \\
\text { surface contamination }\end{array}$ & $\begin{array}{l}\text { The makeup of the } \\
\text { contamination in the } \\
\text { duct is unknown so two } \\
\text { possible isotopic } \\
\text { distributions are } \\
\text { given. }\end{array}$ & $\begin{array}{l}\text { Brehmm } \\
1996\end{array}$ \\
\hline & $\begin{array}{c}k-3 \\
\text { Filter }\end{array}$ & ${ }^{24} \mathrm{~g}_{0} \mathrm{Ci}{ }_{\mathrm{Sr}}{ }^{137} \mathrm{Cs}$ or each $18 \mathrm{kCi}$ & Particulates & $\begin{array}{l}\text { Based on } 20 \mathrm{R} / \mathrm{hr} \\
\text { changeout requirement }\end{array}$ & $\begin{array}{l}\text { WESF } \\
\text { ISB }\end{array}$ \\
\hline & \multirow[t]{2}{*}{$\begin{array}{l}\text { Truck- } \\
\text { port }\end{array}$} & $\begin{array}{c}15 \mathrm{KCi} \text { of } 137 \mathrm{Cs} \text { or } \\
\mathrm{Sr} \text { contained in } \\
\text { waste cask }\end{array}$ & $\begin{array}{l}\text { One 208-L ( } 55-\text { gai }) \\
\text { drum of contaminated } \\
\text { sot id waste. }\end{array}$ & & $\begin{array}{l}\text { Smith } \\
1995\end{array}$ \\
\hline & & $\begin{array}{l}9 \mathrm{Ci}_{\mathrm{Cr}}^{137} \mathrm{Cs} \text { and } 1 \mathrm{Ci} \\
\mathrm{Sr} \text { plastic bags }\end{array}$ & $\begin{array}{l}\text { Contaminated } \\
\text { combustibles }\end{array}$ & & $\begin{array}{l}\text { HESF } \\
\text { ISB }\end{array}$ \\
\hline $\begin{array}{l}\text { Direct } \\
\text { Radiation }\end{array}$ & $\begin{array}{l}\text { see } \\
\text { above }\end{array}$ & - - & $\cdots$ & -- & -- \\
\hline $\begin{array}{l}\text { Toxic } \\
\text { material }\end{array}$ & -- & none & -.. & $\cdots$ & $\cdots$ \\
\hline Carcinogen & $\cdots$ & none & -- & $\cdots$ & $\cdots$ \\
\hline B ichazard & $\cdots$ & none & $\cdots$ & $\cdots$ &.- \\
\hline Asphyxiant & -. & none & -.. & ... & $\ldots$ \\
\hline \multirow[t]{2}{*}{$\begin{array}{l}\text { Flammable } \\
\text { material }\end{array}$} & $\begin{array}{l}\text { Truck- } \\
\text { port }\end{array}$ & $\begin{array}{l}30 \text { (max) bags of lou } \\
\text { level sol id waste }\end{array}$ & $\begin{array}{l}\text { mixed cellulose } \\
\text { material and plastic }\end{array}$ & & \multirow{2}{*}{$\begin{array}{l}\text { Hughe } \\
\text { s } \\
\text { Assoc } \\
\text { iates } \\
1996\end{array}$} \\
\hline & $\begin{array}{l}\text { Hot } \\
\text { Cells }\end{array}$ & Several killograms & $\begin{array}{l}\text { mixed celulose } \\
\text { material and plastic }\end{array}$ & & \\
\hline $\begin{array}{l}\text { Reactive } \\
\text { material }\end{array}$ & $\cdots$ & none & $\cdots$ & $\cdots$ & $-\cdot$ \\
\hline $\begin{array}{l}\text { Explosive } \\
\text { material }\end{array}$ & $\begin{array}{l}\text { Pool } \\
\text { Cell } \\
\text { Area }\end{array}$ & $\cdots$ & Hydrogen & $\begin{array}{l}\text { Generated by } \\
\text { radiolytic } \\
\text { decomposition of water }\end{array}$ & $\begin{array}{l}\text { sieme } \\
\text { r } \\
1996\end{array}$ \\
\hline
\end{tabular}




\section{REVIEW COMMENT RECORD (RCR)}

\begin{tabular}{|l|l|}
\hline 1. Date & 2. Review No. \\
\hline 3. Project No. & 4. Page \\
& \multicolumn{2}{|c|}{7 of 4} \\
\hline
\end{tabular}

Table 3.3.2.1-1. WESF Hazard Identification Results (3 Sheets)

\begin{tabular}{|c|c|c|c|c|c|}
\hline \multirow[t]{3}{*}{ Hazard } & Location & Quantity & Form & Remarks & Ref. \\
\hline & $\begin{array}{l}\text { K-3 } \\
\text { Filter } \\
\text { Box }\end{array}$ & $\cdots$ & Hydrogen & $\begin{array}{l}\text { Generated by } \\
\text { radiolytic } \\
\text { decomposition of water } \\
\text { if the filter box is } \\
\text { flooded. }\end{array}$ & $\begin{array}{l}\text { Siene } \\
\mathrm{r} \\
1996\end{array}$ \\
\hline & $T K-100$ & $\cdots$ & Hydrogen & $\begin{array}{l}\text { Sane as } k-3 \text { filter } \\
\text { box. }\end{array}$ & $\begin{array}{l}\text { siene } \\
r \\
1996\end{array}$ \\
\hline $\begin{array}{l}\text { Incompatib } \\
\text { le } \\
\text { chemical } \\
\text { reaction } \\
\text { products }\end{array}$ & & none & $\cdots$ & $\cdots$ & -- \\
\hline $\begin{array}{l}\text { Electrical } \\
\text { energy }\end{array}$ & - & none & -- & $\cdots$ & $\cdots$ \\
\hline \multirow[t]{5}{*}{$\begin{array}{l}\text { Kinetic } \\
\text { energy }\end{array}$} & $\begin{array}{l}\text { Pool } \\
\text { Cel ts } \\
1 \& 8-11\end{array}$ & $\begin{array}{l}3 \text { coverblocks on each } \\
\text { cell (except Cell } 1 \\
\text { has only 1) }\end{array}$ & $\begin{array}{l}6.35 \text { t ( } 7 \text { tons) each, } \\
76-\mathrm{cm}(30-i n .) \text { thick, } \\
\text { high density concrete }\end{array}$ & $\cdots$ & $\begin{array}{l}\text { sieme } \\
r \\
1996\end{array}$ \\
\hline & $\begin{array}{l}\text { A, E, } C \text {, } \\
\text { and } \\
\text { Hot } \\
\text { Cel t:s }\end{array}$ & $\begin{array}{l}2 \text { coverblocks on each } \\
\text { cell }\end{array}$ & $\begin{array}{l}10-13 \text { t }(11-14 \text { tons), } \\
89-\mathrm{cm} \text { ( } 35-\mathrm{in} .) \text { thick } \\
\text { high density concrete }\end{array}$ & -- & $\begin{array}{l}\text { sieme } \\
\mathbf{r} \\
1996\end{array}$ \\
\hline & $\begin{array}{l}\text { D ard E } \\
\text { Hot } \\
\text { Cel ls } \\
\text { combined }\end{array}$ & $\begin{array}{l}5 \text { total on both hot } \\
\text { cells }\end{array}$ & $\begin{array}{l}9.5-13 \text { t }(10.5-14 \\
\text { tons }), 89-\mathrm{cm}(35-\mathrm{in} .) \\
\text { thick high density } \\
\text { concrete }\end{array}$ & & \\
\hline & $\begin{array}{l}\text { G Hdt } \\
\text { Cell }\end{array}$ & 4 coverblocks & $\begin{array}{l}8-11 \text { t }(9-12 \text { tons }) \\
89-\mathrm{cm}(35-i n .) \text { thick } \\
\text { high density concrete }\end{array}$ & & \\
\hline & $\begin{array}{l}\text { Truokpor } \\
\text { t }\end{array}$ & 2 coverblocks & $13.6 \div$ (15 tons) & & $\begin{array}{l}\text { siene } \\
r_{1996}\end{array}$ \\
\hline
\end{tabular}




\section{REVIEW COMMENT RECORD (RCR)}

\begin{tabular}{|l|l|}
\hline 1. Date & 2. Review No. \\
\hline $08 / 09 / 96$ & 4. Page \\
\hline 3. Project No. & \multicolumn{1}{|c|}{8 of 4} \\
\hline
\end{tabular}

Table 3.3.2.1-1. WESF Hazard Identification Results (3 Sheets)

\begin{tabular}{|c|c|c|c|c|c|}
\hline \multirow[t]{6}{*}{ Hazard } & Location & Quant ity & Form & Remarks & Ref. \\
\hline & & Buss $^{?}$ Cask & $\begin{array}{l}\text { cylindrical cask, } \\
-1.52 \mathrm{~m}(-5 \mathrm{ft}) \text { in } \\
\text { diameter and }-2.13 \mathrm{~m} \\
(-7 \mathrm{ft}) \text { high. } 16.8 \mathrm{t} \\
(18.5 \mathrm{tons})\end{array}$ & & \\
\hline & & WESF waste cask & $9+(10$ tons $)$ & & \\
\hline & $\begin{array}{l}\text { Pool } \\
\text { Cell } \\
\text { Area }\end{array}$ & 1 coverblock overhead & $6.8 t(7.5$ tons $)$ & & $\begin{array}{l}\text { sieme } \\
\Gamma \\
1996\end{array}$ \\
\hline & $\begin{array}{l}k-3 \\
\text { Filter } \\
\text { Pit }\end{array}$ & 9 coverblocks & $\begin{array}{l}3.6 \text { t ( } 4 \text { tons }) \text { each, } \\
51-\mathrm{cm}(20-\mathrm{in} .) \text { thick } \\
\text { structural concrete }\end{array}$ & & $\begin{array}{l}\text { Sieme } \\
r \\
1996\end{array}$ \\
\hline & $\begin{array}{l}\text { TK- } 100 \\
\text { Pit }\end{array}$ & 3 coverblocks & $\begin{array}{l}7.3 \mathrm{t} \text { ( } 8 \text { tons) each, } \\
61-\mathrm{cm}(24-\mathrm{in.}) \text { thick } \\
\text { structural concrete }\end{array}$ & & $\begin{array}{l}\text { sieme } \\
r \\
1996\end{array}$ \\
\hline $\begin{array}{l}\text { High } \\
\text { pressure }\end{array}$ & $\cdots$ & none & $\cdots$ & $\cdots$ &.- \\
\hline Lasers & -- & none & $\cdots$ & $\cdots$ & $\cdots$ \\
\hline $\begin{array}{l}\text { Potential } \\
\text { energy }\end{array}$ & $\cdots$ & none & $\cdots$ & $\cdots$ & $\cdots$ \\
\hline $\begin{array}{l}\text { Accelerato } \\
\text { rs }\end{array}$ & -- & none & $\cdots$ & $\cdots$ & $\cdots$ \\
\hline $\begin{array}{l}x-r a y \\
\text { machines }\end{array}$ & -- & none & $\cdots$ & $\cdots$ & $\cdots$ \\
\hline
\end{tabular}

\section{Beneficial Uses Shipping System}




\section{REVIEW COMMENT RECORD (RCR)}

\begin{tabular}{|l|l|}
\hline $\begin{array}{l}\text { 1. Date } 8 / 14 / 96 \\
\text { 3. Project Mo. }\end{array}$ & 2. Review Mo. \\
\hline & 4. Page 1 of 8 \\
\hline
\end{tabular}

\begin{tabular}{|c|c|c|c|c|}
\hline $\begin{array}{l}\text { 5. Document Number(s)/Title(s) } \\
\text { WHC-SD-WH-ISB-009, Rev } 0\end{array}$ & $\begin{array}{l}\text { 6. Program/Project/ } \\
\text { Building Number } \\
\text { WESF ISB } / 225 B\end{array}$ & $\begin{array}{l}\text { 7. Reviewer } \\
\text { D. D. Beers }\end{array}$ & $\begin{array}{l}\text { 8. Organization/Group } \\
\text { 16H00/Rad Control }\end{array}$ & $\begin{array}{l}\text { 9. Location/Phone } \\
\text { 222B/8B/373-0766 }\end{array}$ \\
\hline
\end{tabular}

17. Coment subrittal Approval:

Organization Menager (Optional)
11. CLOSED

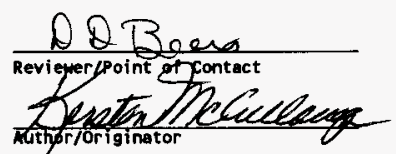

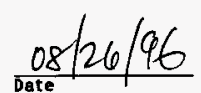

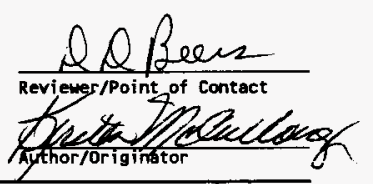

12. 13. Comment(s)/Discrepancy(s) (Provide technical justification for the coment and detailed recomandation of the
resolve the discrepancy/problem indicated.)

16.0 , "Safety Related Programs and Controls," Pg 6-1, Entire Section: Comment: Revise to reflect a scope limitation on occupational radiation protection. See attached file, with proposed revisions.

BASIS: The scope of my review, under the time constraints, must be limited to occupational radiation protection.

\begin{tabular}{|c|c|c|}
\hline $\begin{array}{l}14 . \\
\text { Pold } \\
\text { Point }\end{array}$ & 15. Disposition (Provide justification if NOT accepted.) & $\begin{array}{l}16 . \\
\text { Status }\end{array}$ \\
\hline & $\begin{array}{l}\text { See the mark up of the recommended text } \\
\text { below. This Chapter involved the total } \\
\text { radiation protection program with emphasis } \\
\text { on personnel in order to maintain } \\
\text { administrative control of the WESF facility } \\
\text { which is discussed in Chapters } 3,4 \text { and } 5 \text {. } \\
\text { This section is described in } 3009 \text { as } \\
\text { describing in summary the program with } \\
\text { reference to procedures. }\end{array}$ & $\begin{array}{l}O K \\
A Q B e c \\
0 \& / 210 / 9\end{array}$ \\
\hline
\end{tabular}

16.

$K$ Qbencis Plabi radiation protection program with emphasis

wich is discussed in Chapters 3,4 and 5 . reference to procedures. 


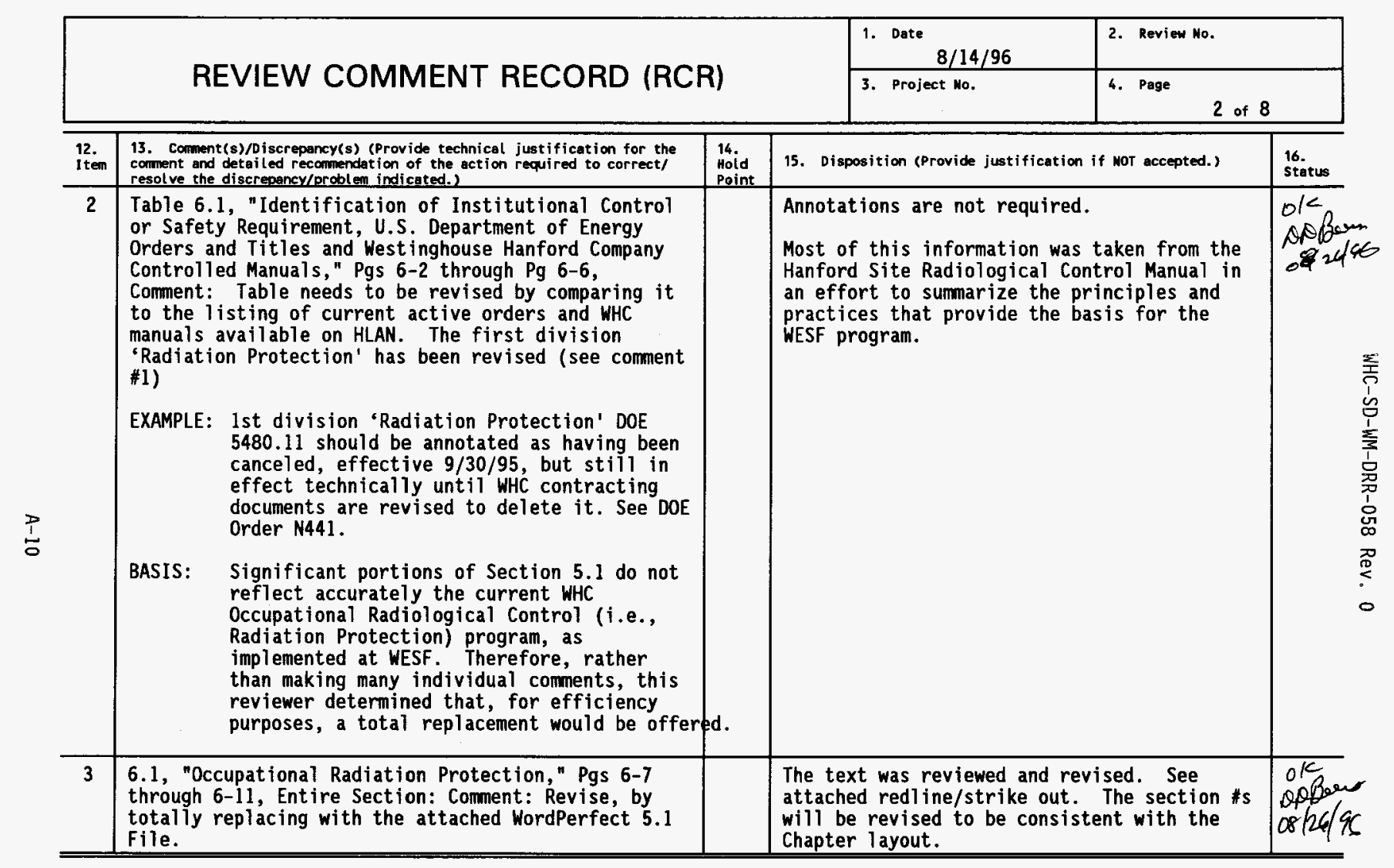




\section{REVIEW COMMENT RECORD (RCR)}

1. Date
$8 / 14 / 96$

2. Review Mo.

3. Project No.

4. Page

3 of 8

\section{A. ofCUPATIOHAL RADIATION PROTECTION}

Section 6.1 summarizes the essential features of the oceuptionat radiation protection program as it relates to worker radiological safety at WESF. The WESF radiation protection program is designed and implemented pimarily to provide a radiologically safe work place for occupational radiological workers, other facility personnel, and visitors. Sulation radion protion of potential accidents described in Chapter 3.0 .

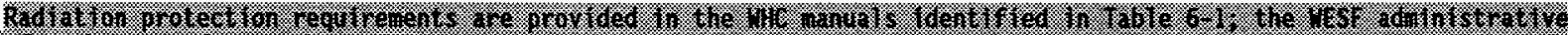

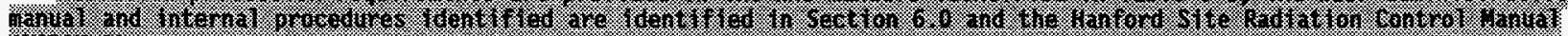
$\cos +6$

\section{Radiation Protection Program and Organization}

The radiation protection program within the Westinghouse Hanford Company (WHC) is administered and coordinated at the company level by the Safety, Quality and Radiation Control Services (SQRC) organization, in order to promote consistency in requirements management, implementation, and to maximize the usefulness in sharing developed applications between Hanford facilities. The SQRC organization provides for a centralized requirements management

$\rightarrow$ process, including interpretations and implementation leadership of regulatory and Department of Energy (DOE)

$\doteq$ contratual based

The-WESF ocempational padiation-protection program has two main requirements components, 11 i 7 egal aspect (HOCFA835), and 2) a contractual aspect (HSACH-1). These two main soures of programatic and implementation drivers are briefiy stmmapized below.

\footnotetext{
The pegulatory based ocetpational padiation protection program-and implementation-at-WESF-is documented in the WHC Radiation Protection Program (WHC SP 1145, Revision 1). This document responds to the recently issued codification of occupational padiation protection rutes (10CFR835) by the DOE, by describing the basis fop radiologically compliant operations as implemented at WESF.

The contractual-based occupational radiation protection-program-and implementation-at WESF is based-on the Hanford Site- Radiological Control Mantul (HSRCM1, Revision 2).
}

The-legal and-contractual requirements have-been combined into-a-single-resource-document (the-WESF-Standards-and

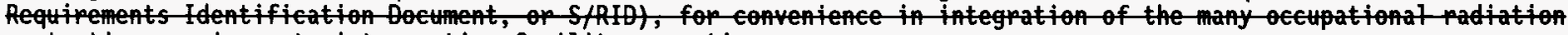
protection requirements into routine facility-operations. 


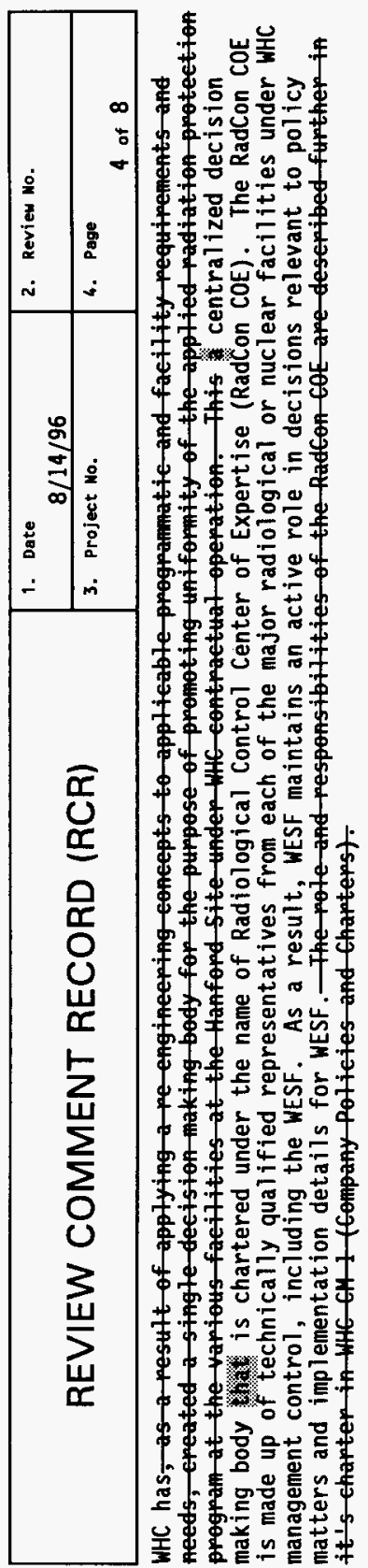




\section{REVIEW COMMENT RECORD (RCR)}

\begin{tabular}{|l|l|}
\hline $\begin{array}{l}\text { 1. Date } \\
8 / 14 / 96\end{array}$ & 2. Review No. \\
\hline 3. Project No. & 4. Page \\
\end{tabular}

WESf has recently undergone-re-engineering, and has changed from the classical matrixed-management approach to-a self

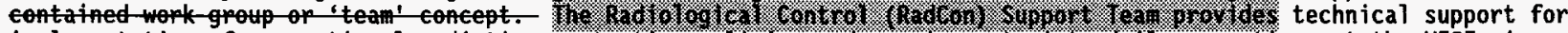
implementation of occupational radiation protection policies and requirements into daily operations at the WESF. is

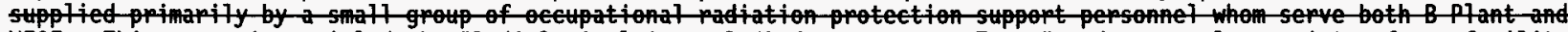
WESF. This group is entitled the "Radiological Control (RadCon) Suppont Tean," and curpently consists-of-one-facility Aadiologicul Control Hanagep (RCM), one person fulfillting the duties of the HSRCH I position desenibed as the Radiological Control organization first line supervisor, one padiological control analyst, one health physicist, and one Radiological control-Fechnician. The RadCon Stpport staff covers both WESF and B Plant. Qualifications of the RadCon Suppopt staff include-degrees (some-advaned) in appoppiate-technical fields related to oecupational radiation protection, certification by nationally recognized testing and accreditation bodies, and a combination-of several decades of applied octpational radiation protection in several different aspects of applied nutelear technology.

The-facility RCH has dipect acess to the WESF-Operations managen, on an equal basis, and also has dipect access to the B Plant/WESF Qirectors, as an independent line-of acess for matters potentially requiring resolution beyond normal methods. Additionally, the facility RCH is also pepresents WESF on the RadCon-COE, with full authority of the WESF Oinetors.

\section{$\stackrel{\omega}{\omega}$ 2. As Low As Reasonably Achievable Policy and Program}

The comprehensive WHC and WESF ALARA policy is to prevent human and environmental exposures to radiological or hazardous conditions adverse to ALARA. The program describes responsibilities for management, facility staff and facility support staff such as the radiation control specialists. Requirements are described for reporting, recording and implementing ALARA into the facility operational activities and training.

A more narrow focused ALARA policy for occupational radiation protection at WESF is for all exposures to radiological hazards and conditions to be maintained as low as reasonably achievable. Each person has specific responsibilities related to achieving and maintaining ALARA goals, appropriate for job categories and facility objectives.

The-WESF As Low as Reasonably-Achievable- (ALARA) policy and a mantlal (WHC CH 5-6), Section 5.4 (ALARA Program-at B Plant/HESF Complex). 


\section{REVIEW COMMENT RECORD (RCR)}

1. Date
$8 / 14 / 96$

3. Project No.
2. Review No.

4. Page

\section{Radiological Protection Training}

Standing or long term radiological protection training requirements for personnel working at or near WESF is provided through the Hanford Site training program. The program includes a multi-layered Radiation Protection Training Program that provides a level of training that corresponds to an individual's classification as well as the individual's specific work assignments. Additional radiological training on facility specific requirements (facility radiological

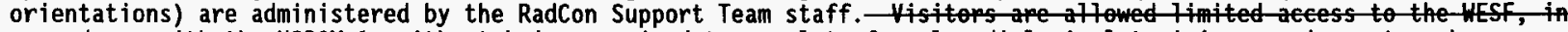
accordance with the HSRCH 1, without being required to complete-fomal radiological training requirements, when escorted by qualified facility-ectpational radiological workers.

Five-training categonies are provided, in order to implement the graded appoach-to oceupational radiation protection training requirements:

General employee radiological training:

fow hazard level oceupational padiological workep training:

General support pepsonnel oefpational radiologieal-workep training;

high hazard occupational radiological workep training:

i specialize oceupational padiological control technician training;

$\stackrel{1}{\circ}$

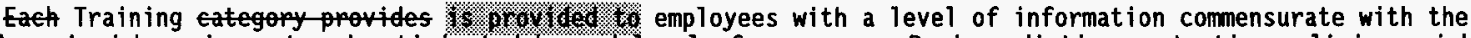
employee's job assignment and anticipated hazard level of exposure. Basic radiation protection policies, risks and radiation protection applications such as radiological postings, emergency procedures and use of dosimeters are addressed. Supervisors and managers are required to complete training commensurate with their responsibilities and work scope. More detailed training is provided to radiological workers and radiological control technicians and the related management. The training addresses applied radiological work situations typical for various hazard levels of radiological areas.

Continuing training requirements are tracked for each occupational radiological worker assigned to or visiting the WESF, at intervals that are assigned to specific training courses. Records are maintained, in particular for those individuals that are required to achieve and maintain occupational radiological worker qualifications. 


\section{REVIEW COMMENT RECORD (RCR)}

\begin{tabular}{|l|l|}
\hline $\begin{array}{l}\text { 1. Date } \\
8 / 14 / 96\end{array}$ & 2. Review No. \\
\hline 3. Project No. & 4. Page \\
& \\
\hline
\end{tabular}

\section{Radiation Exposure Control}

Overall radiation-expsure-at WESF is maintained in acodance-with the-Administrative-Control tevels (ACLs) that are established-in the HSRCH 1. These ACLs ape below the regulatory limits of 10 CFR835, in opder to administratively

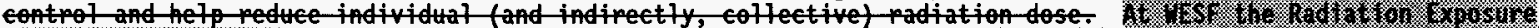

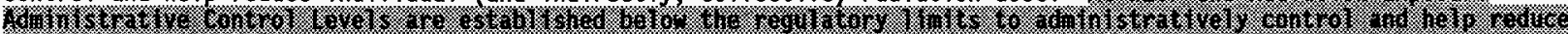

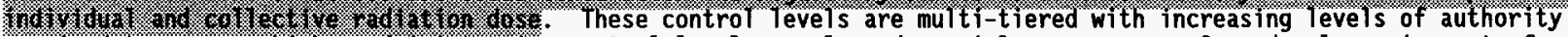
required to approve higher administrative control levels or planned special exposures. Procedural requirements for summing internal and external radiation exposures are implemented at WESF, by procurement of centralized dosimetry services, standards, and procedures.

Radiation exposure control at WESF is managed on a daily basis through the implementation of the radiological review process for technical work documents such as operational and maintenance procedures, and work packages for work to be completed in radiological areas. The reviews are conducted by the cognizant facility staff members and assigned radiation control staff who are responsible for supporting the completion of the work assignment.

Radiological areas at WESF are posted with radiological notifications as

$\stackrel{1}{\mathrm{c}}$ radiation work permits are issued at WESF according to the Hanford-site HSRCH 1. WESF radiation protection program.

Access control requirements at WESF is is implemented by the Access Entry Control System (ACES) computer based system, which allows verification of critical qualifications prior to radiological area entry authorization, in order to control access to radiological areas. training, personnel protective equipment including respiratory protection equipment, and other key control parameters critical for occupational radiation protection implementation are monitored and administered at WESF by the ACES station operator. 


\section{REVIEW COMMENT RECORD (RCR)}

1. Date
$8 / 14 / 96$

3. Project No.
2. Review No.

4. Page

\section{Radiological Monitoring, Instrumentation, and Record Keeping}

Radiological monitoring devices and radiological protection instrumentation are provided throughout WESF. Chapter 2.0 provides a description of the monitoring devices and radiological protection instrumentation. Chapters 3.0 , 4.0 and 5.0 discuss monitoring devices and protection instrumentation that is important for mitigating and/or preventing the analyzed accidents.

Occupational radiological monitoring devices at WESF are generally categorized as fixed (stationary) or portable. The fixed monitoring systems and devices are generally limited to applications within building confines of WESF. The portable monitoring devices are used to monitor both the internal occupational radiological conditions associated with WESF and external radiological conditions.

Fixed radiological monitoring devices at WESF that are used to support the occupational radiation protection program (or to support facility safety) include the following types: area monitoring systems (direct radiation monitor application) and personnel contamination self-survey stations (frisking booths). Portable radiological monitoring devices at WESF that are used to support the occupational radiation protection program include a variety of hand held instrumentation, such as ion chambers, contamination friskers, and air monitoring equipment.

Independent near-facility monitoring, external to the facility, is also conducted by others within whC, to verify $\rightarrow$ and confirm the impacts of WESF operations.

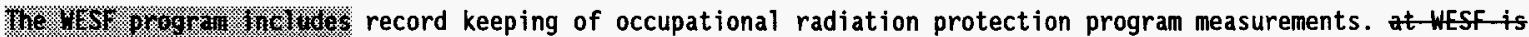
conduted with the requirements of 10 CFRB35 and the HSREM 1 - 


\section{REVIEW COMMENT RECORD (RCR)}

1. Date

2. Review No.

3. Project No.

1 of

\begin{tabular}{l|l|l|l|l}
\hline 5. Document Munber(s)/Title(s) & $\begin{array}{l}\text { 6. Program/Project/ } \\
\text { Building Humber } \\
\text { WESF }\end{array}$ & $\begin{array}{l}\text { 7. Reviewer } \\
\text { R. E. Broz }\end{array}$ & $\begin{array}{l}\text { 8. Organization/Grap } \\
\text { Emergency } \\
\text { Preparedness }\end{array}$ \\
\hline
\end{tabular}

17. Comment submittal Approval:

10. Agreement with indicated comment disposition(s)

Organization Manager (Optional)

$$
\frac{8-3 c-9 b}{\text { oate }}
$$

\section{Date}

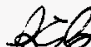

Reviewer/Point of Contac

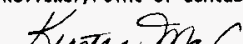

Tuaze 9720 author/originator
11. CLOSED

$8-30-96$ Date
A/372-1651

\begin{tabular}{|c|c|c|c|c|}
\hline $\begin{array}{l}12 . \\
1 \text { tem }\end{array}$ & $\begin{array}{l}\text { 13. Comment(s)/Discrepancy(s) (Provide technical justification for the } \\
\text { comment and detailed recommendation of the action required to correct/ } \\
\text { resolve the discrepancy/problem indicated.) }\end{array}$ & $\begin{array}{l}14 . \\
\text { Hoid } \\
\text { Point }\end{array}$ & 15. Disposition (Provide justification if NOT accepted.) & $\begin{array}{l}16 . \\
\text { status }\end{array}$ \\
\hline 1. & $\begin{array}{l}\text { Page 6-4, Table } 6-1,5 \text {; WHC-CM-4-44 has been } \\
\text { recalled. Delete reference to this manual. Suggest } \\
\text { that DOE/RL-94-02, Hanford Emergency Response Plan } \\
\text { be added in front of WHC-CM-4-43. }\end{array}$ & & $\begin{array}{l}\text { WHC-CM-4-44 is deleted. } \\
\text { DOE/RL-94-02, Emergency Preparedness Plan is } \\
\text { added to the } 1 \text { ist. }\end{array}$ & \\
\hline 2. & $\begin{array}{l}\text { Page } 6-4 \text {, Table } 6-1,6 . ; 5480.18 \text { A has been } \\
\text { cancelled and should be replaced by } 5480.18 \mathrm{~B}, \\
\text { Nuclear Facility Training Accreditation Program. }\end{array}$ & & $\begin{array}{l}5480.18 \mathrm{~A} \text { is deleted and replaced by } \\
5480.18 \mathrm{~B} \text {, Nuclear Facility Training } \\
\text { Accreditation Program unless the WESF } \\
\text { training person Steve Meyers objects. }\end{array}$ & \\
\hline & & & & \\
\hline & & & & \\
\hline & & & & \\
\hline & & & & \\
\hline & & & & \\
\hline & & & & \\
\hline & & & & \\
\hline & & & & \\
\hline & & & & \\
\hline & & & & \\
\hline & & & & \\
\hline
\end{tabular}


WHC-SD-WM-DRR-058 Rev. 0

This page intentionally left blank. 


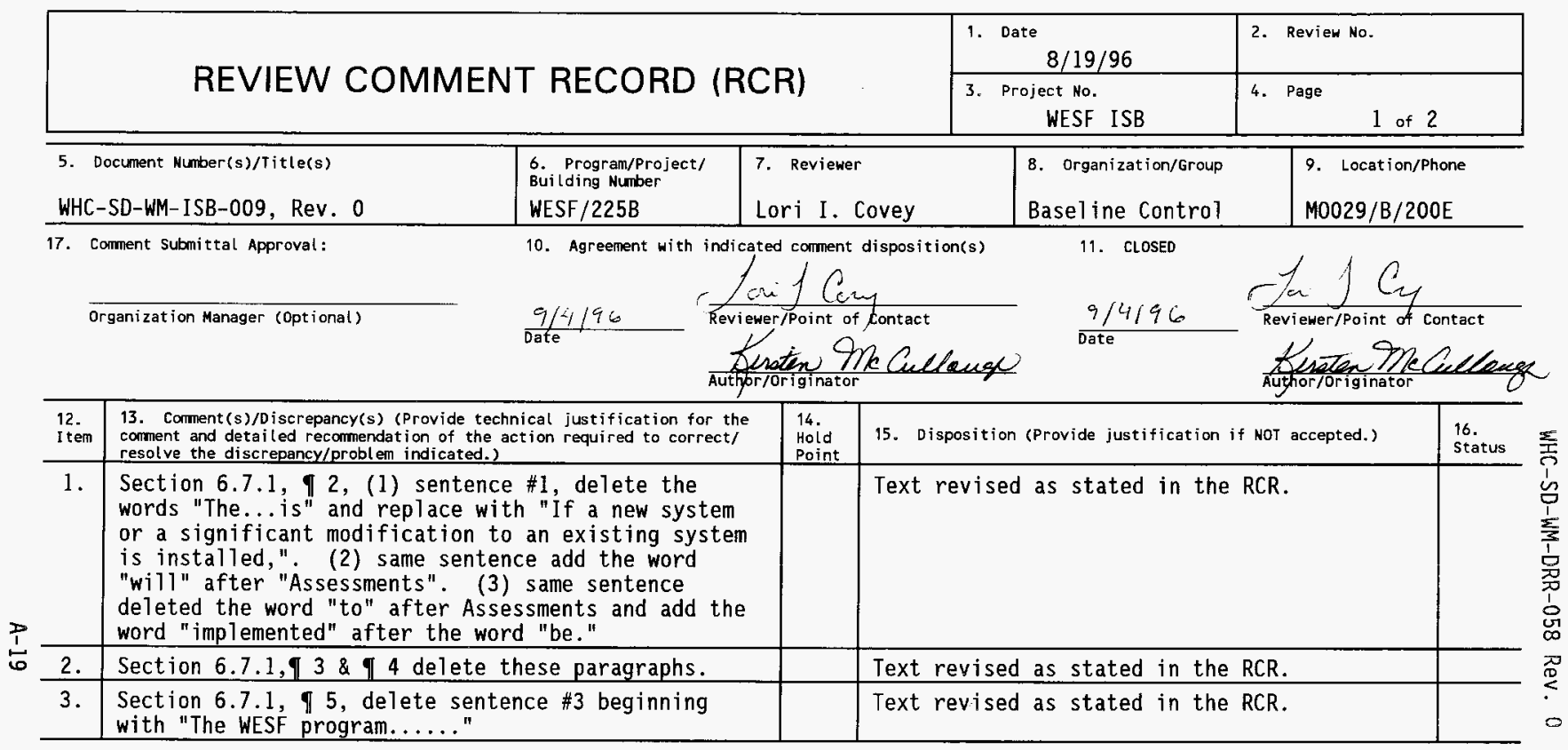




\begin{tabular}{|c|c|c|c|c|c|}
\hline \multirow{2}{*}{\multicolumn{3}{|c|}{ REVIEW COMMENT RECORD (RCR) }} & 1. Date $8 / 19 / 96$ & \multicolumn{2}{|l|}{ 2. Review No. } \\
\hline & & & $\begin{array}{l}\text { 3. Project No. } \\
\text { WESF ISB }\end{array}$ & \multicolumn{2}{|l|}{ (n) } \\
\hline $\begin{array}{l}12 . \\
\text { Item }\end{array}$ & $\begin{array}{l}\text { 13. Corment(s)/Discrepancy(s) (Provide technical justification for the } \\
\text { corment and detailed recommendation of the action required to correct/ } \\
\text { resolve the discrepancy/problem indicated.) }\end{array}$ & $\begin{array}{l}14 . \\
\text { Hold } \\
\text { Point }\end{array}$ & \multicolumn{2}{|c|}{ 15. Disposition (Provide justification if NOT accepted.) } & $\begin{array}{l}\text { 16. } \\
\text { Status }\end{array}$ \\
\hline 4. & $\begin{array}{l}\text { Section } 6.7 .2 \text {, \# \#1, (1) Sentence \#1, delete the } \\
\text { words "the Job Control System (JCS)" and insert "an } \\
\text { automated recal system" (2) Sentence \#2, delete } \\
\text { "JCS" and insert recall system. (3) Sentence \#3, } \\
\text { delete "JCS" and replace with "recall system" ; } \\
\text { delete the word "relative" and insert the word } \\
\text { "related"; add the letters WESF infront of Interim; } \\
\text { delete the wording in the rest of the sentence } \\
\text { beginning with "identified in Chapter } 5.0 \ldots \ldots . . . . . \\
\text { leave in (WhC 1996a). (4) Sentence \#4, Replace } \\
\text { "Interim Operational Safety Requirements" with I0SR; } \\
\text { insert "identified and after the words "requirements } \\
\text { are"; insert the words "recall system" after the } \\
\text { words "into the" and delete the remainder of the } \\
\text { sentence beginning with "JCS and are identified } \\
\text { as......." }\end{array}$ & & \multicolumn{2}{|c|}{ Text revised as stated in the RCR. } & \\
\hline 5. & $\begin{array}{l}\text { Section } 6.7 .2,02 \text { (1) Sentence \#1 delete "JcS" and } \\
\text { insert "recall system" (2) Sentence \#3 delete the } \\
\text { words "Work packages are generated and"; delete the } \\
\text { "JCS" and replace with recall system. (3) add the } \\
\text { word "activity" after the word "completed" and } \\
\text { delete the remainder of the sentence beginning with } \\
\text { "surveillance on......." }\end{array}$ & & \multicolumn{2}{|c|}{ Text revised as stated in the RCR. } & \\
\hline \multirow[t]{4}{*}{6.} & Section 6.7 .2 , delete 13 & & \multicolumn{2}{|c|}{ Text revised as stated in the RCR. } & \\
\hline & & & \multicolumn{2}{|c|}{$\begin{array}{l}\text { The above RCRs are based on attached text } \\
\text { submitted for revising text. }\end{array}$} & \\
\hline & & & & & \\
\hline & & & & & \\
\hline
\end{tabular}

\section{A. INITIAL TESTING, IN-SERVICE SURVEILLANCE, AND MAINTENANCE}




\section{REVIEW COMMENT RECORD (RCR)}

\begin{tabular}{|l|l|}
\hline $\begin{array}{l}\text { 1. Date } \\
8 / 19 / 96\end{array}$ & 2. Review No. \\
\hline $\begin{array}{c}\text { 3. Project No. } \\
\text { WESF ISB }\end{array}$ & $\begin{array}{l}\text { 4. Page } \\
3 \text { of } 2\end{array}$ \\
\hline
\end{tabular}

The testing, in-service surveillance, and maintenance programs and procedures are designed and implemented to support the mitigation of and/or prevention of the accidents analyzed in Chapter 3.0 .

\section{Initial Testing}

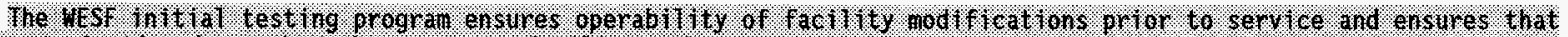

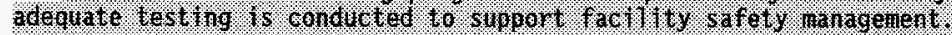

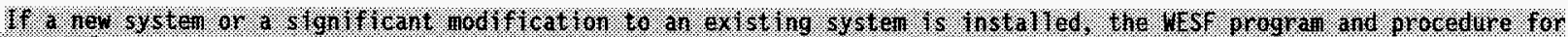

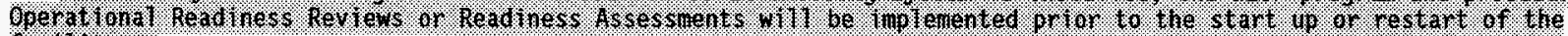
10.19:1\%:

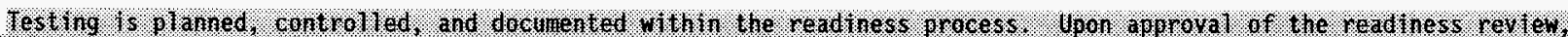

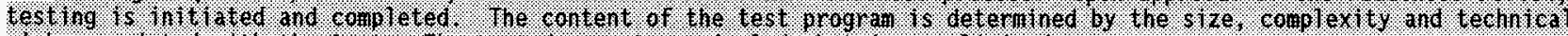

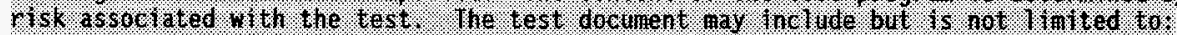

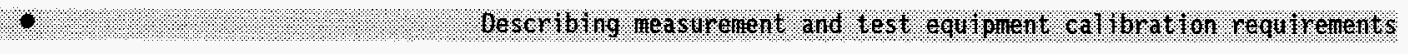

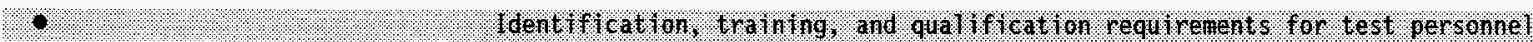

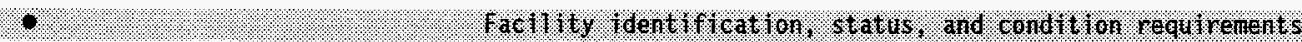

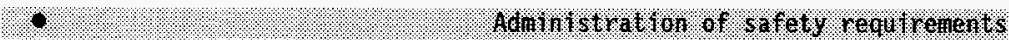

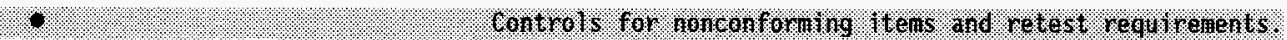

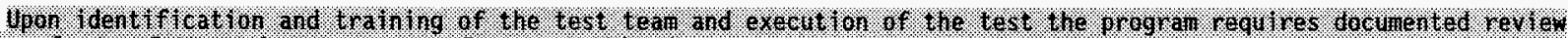

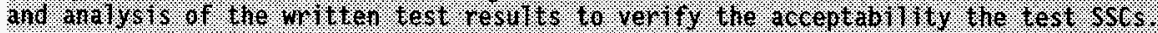

\section{In-Service Surveillance and Maintenance Program}

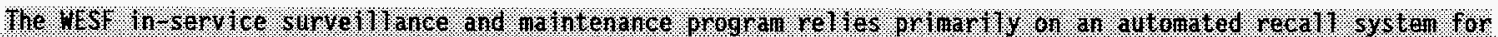

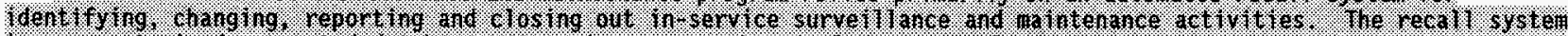

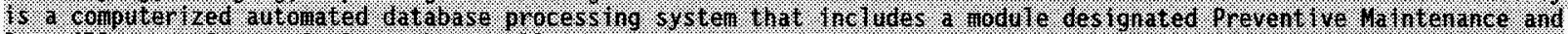

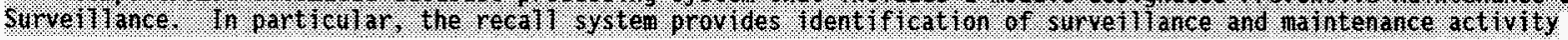




\section{REVIEW COMMENT RECORD (RCR)}

\begin{tabular}{|l|l|}
\hline $\begin{array}{l}\text { 1. Date } \\
8 / 19 / 96\end{array}$ & 2. Review No. \\
\hline $\begin{array}{c}\text { 3. Project No. } \\
\text { WESF ISB }\end{array}$ & 4. Page \\
\hline
\end{tabular}

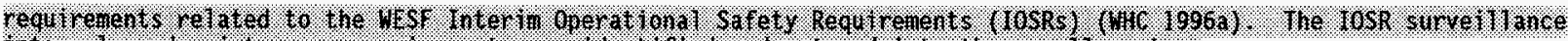

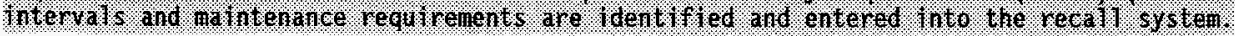

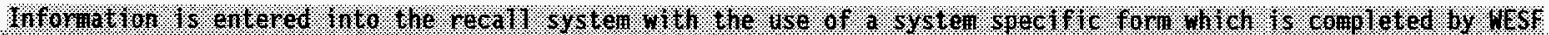

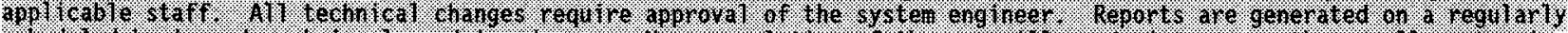

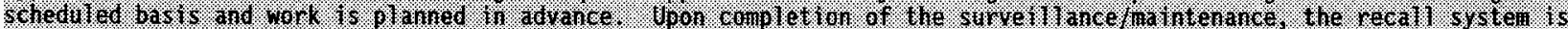

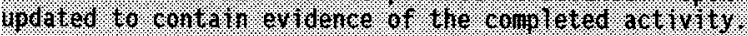




\begin{tabular}{|l|l|l|}
\hline \multirow{2}{*}{ REVIEW COMMENT RECORD (RCR) } & 1. Date $07 / 30 / 96$ & \multicolumn{2}{|c|}{ Review No. } \\
\cline { 2 - 3 } & 3. Project No. & $4 . \quad$ Page \\
\end{tabular}

\begin{tabular}{l|l|l|l|l}
\hline $\begin{array}{l}\text { 5. Document Munber(s)/Title(s) } \\
\text { WHC-SD-WM-ISB-009, Rev 0 }\end{array}$ & $\begin{array}{l}\text { 6. Program/Project/ } \\
\text { Building Munber } \\
\text { WESF/225B }\end{array}$ & $\begin{array}{l}\text { 7. Reviewer } \\
\text { T. Gainey }\end{array}$ & $\begin{array}{l}\text { 8. Organization/Group } \\
16 E 00 / \text { Capsule } \\
\text { Management Team }\end{array}$ & \begin{tabular}{l} 
M0-029/373-0964 \\
\hline
\end{tabular}
\end{tabular}

17. Comment Submittal Approval:

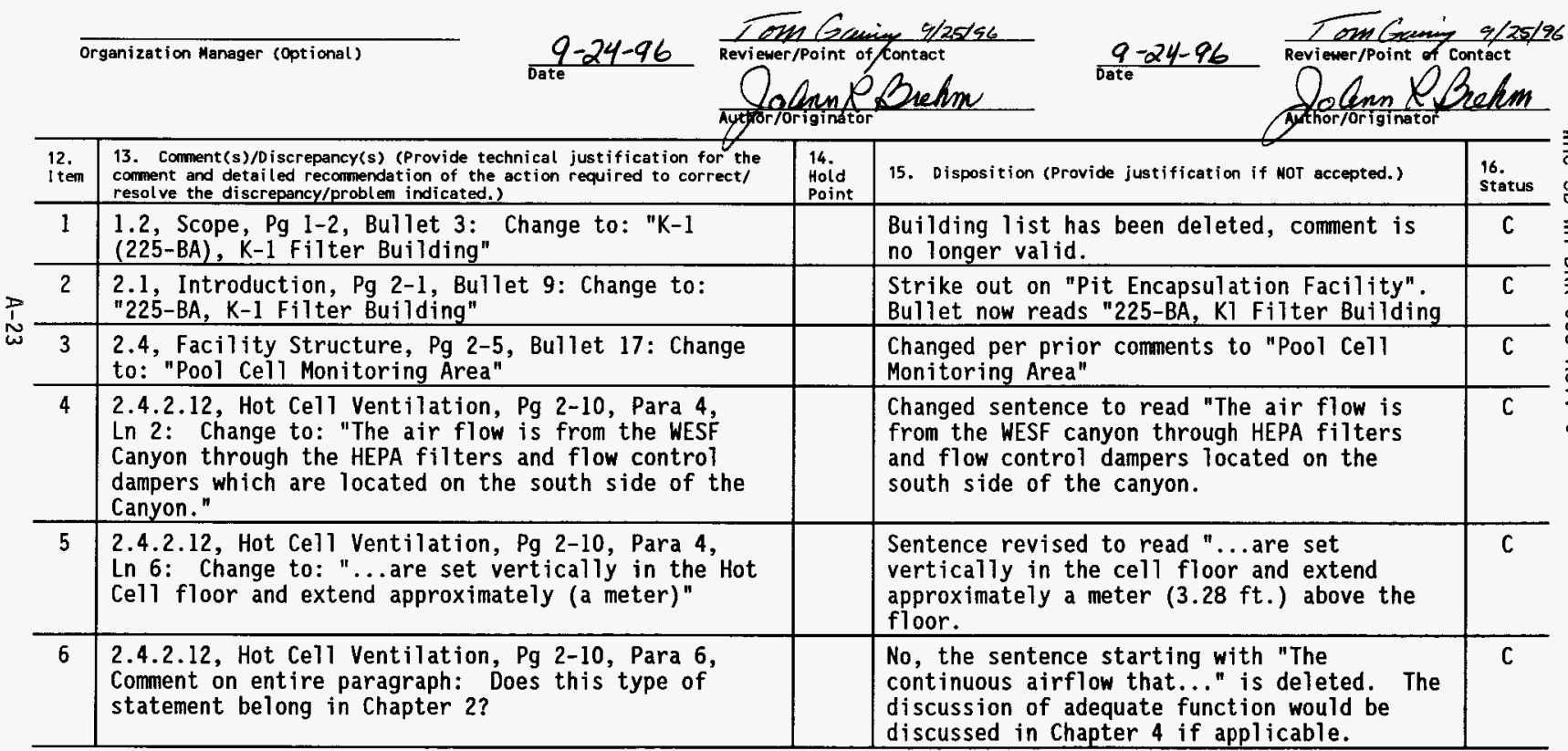




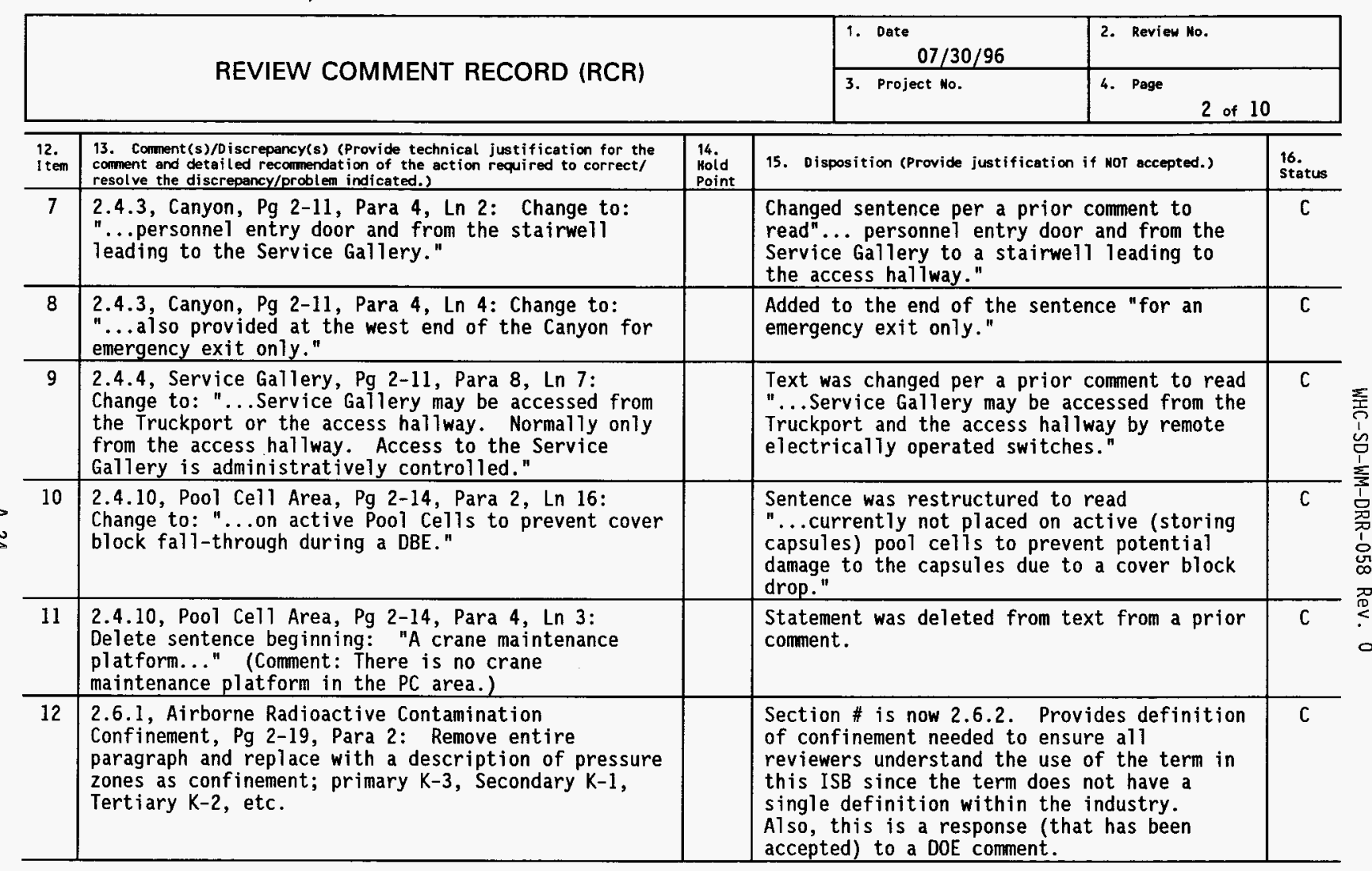




\begin{tabular}{|l|l|l|}
\hline \multirow{2}{*}{ REVIEW COMMENT RECORD (RCR) } & 1. Date & \multicolumn{2}{|c|}{$07 / 30 / 96$} & Review No. \\
\cline { 2 - 3 } & 3. Project No. & 4. Page \\
\hline
\end{tabular}

\begin{tabular}{|c|c|c|c|c|}
\hline $\begin{array}{l}12 . \\
\text { I tem }\end{array}$ & $\begin{array}{l}\text { 13. Corment }(s) / D \text { iscrepancy(s) (Provide technical justification for the } \\
\text { comment and detailed recommendation of the action required to correct/ } \\
\text { resolve the discrepancy/problem indicated.) }\end{array}$ & $\begin{array}{l}\text { Thi. } \\
\text { Hoid } \\
\text { Point }\end{array}$ & 15. Disposition (Provide justification if NOT accepted.) & $\begin{array}{l}16 . \\
\text { status }\end{array}$ \\
\hline 13 & $\begin{array}{l}2.6 .1 .1 \text {, K-1 HVAC Supply and Exhaust System, } \\
\text { Pg 2-19, Para 5, Ln } 1: \text { Change to: "The K-1 exhaust } \\
\text { system provides ventilation exhaust for the Pool } \\
\text { Ce11 area, Transmitter rooms, and manipulator repair } \\
\text { shop as well as for the areas supplied by the K-1 } \\
\text { supply system." }\end{array}$ & & $\begin{array}{l}\text { Section \# is now 2.6.2.1. Added the } \\
\text { "Transmitter rooms, and manipulator repair } \\
\text { shop." }\end{array}$ & C \\
\hline 14 & $\begin{array}{l}2.6 .1 .1, \text { K-1 HVAC Supply and Exhaust System, } \\
\text { Pg 2-19, Para 5, Ln 3: Change to: "...ventilation } \\
\text { flow to the exhaust system removes hydrogen from the } \\
\text { pool cell area..." }\end{array}$ & & $\begin{array}{l}\text { Section \# is now 2.6.2.1. Replaced "dilutes } \\
\text { hydrogen in the air", with "removes hydrogen } \\
\text { from the Pool Cell Area." }\end{array}$ & $\mathrm{C}$ \\
\hline 15 & $\begin{array}{l}\text { 2.6.1.1, K-1 HVAC Supply and Exhaust System, } \\
\text { Pg 2-19, Para 6, Ln 5: Change to: "...exhausts the } \\
\text { air from the filter banks." }\end{array}$ & & $\begin{array}{l}\text { Section is now 2.6.2.1. Changed the word } \\
\text { "through" to "from" the filter banks." }\end{array}$ & c \\
\hline 16 & $\begin{array}{l}\text { 2.6.1.1, K-1 HVAC Supply and Exhaust System, } \\
\text { Pg 2-20, Para 1, Ln } 1: \text { Change to: "... I loss of } \\
\text { K-3 negative duct pressure in the system..." }\end{array}$ & & $\begin{array}{l}\text { See section } 2.6 .2 .3, \mathrm{~K}-3 \text { HVAC supply and } \\
\text { exhaust system, paragraph } 6 \text {, sentence \#3. } \\
\text { Sentence revised to read "Failure of the } \\
\text { online.... (or loss of } \mathrm{K}-3 \text { negative duct } \\
\text { pressure...)..." }\end{array}$ & C \\
\hline 17 & $\begin{array}{l}\text { 2.6.1.2, K-2 HVAC Supply and Exhaust System, } \\
\text { Pg 2-20, Para } 4 \text {, Question on paragraph: What } \\
\text { happened to filtered, heated, or cooled? (See K-1) }\end{array}$ & & $\begin{array}{l}\text { The following sentence is added to paragraph } \\
1 \text { in section } 2.6 .2 .2 \text {, after the second } \\
\text { sentence "The supply air is filtered by } 8 \% \\
\text { and } 80 \% \text { efficiency NBS filters, heated or } \\
\text { cooled appropriately, and distributed } \\
\text { through a duct network to the areas shown on } \\
\text { the airflow diagram. Figure } 2-8 \text {. The } 3 \text { rd } \\
\text { sentence is deleted. }\end{array}$ & C \\
\hline
\end{tabular}




\begin{tabular}{|c|c|c|}
\hline & $\begin{array}{l}\text { 1. Date } \\
07 / 30 / 96\end{array}$ & 2. Review No. \\
\hline REVIEW COMIVIENI RECURD (RCR) & 3. Project No. & 4 of 10 \\
\hline
\end{tabular}

\begin{tabular}{|c|c|c|c|c|}
\hline $\begin{array}{l}12 . \\
\text { Item }\end{array}$ & $\begin{array}{l}\text { 13. Comment(s)/Discrepency(s) (Provide technical justification for the } \\
\text { comment and detailed recommendation of the action required to correct/ } \\
\text { resolve the discrepancy/problem indicated.) }\end{array}$ & $\begin{array}{l}\text { 14. } \\
\text { Hoid } \\
\text { Point }\end{array}$ & 15. Disposition (Provide justification if NOr accepted.) & $\begin{array}{l}16 . \\
\text { status }\end{array}$ \\
\hline 18 & $\begin{array}{l}\text { 2.6.1.2, K-2 HVAC Supply and Exhaust System, } \\
\text { Pg 2-20, Para 6, Comments on paragraph: } \\
\text { Comment 1: HEPA on inlet and outlet of Transmitter } \\
\text { rooms. } \\
\text { Comment 2: K-2 supplies air to the manipulator } \\
\text { repair shop which is exhausted by the K-1. }\end{array}$ & & $\begin{array}{l}\text { Section \# changed to } 2.6 .2 .2 \text {, Added the } \\
\text { following to paragraph } 3 \text { in section } 2.6 .2 .2 \text {, } \\
\text { sentence \# } 2 \text { "...contaminated the supply } \\
\text { and exhaust from..." sentence \#1, added } \\
\text { the following to the end "and Manipulation } \\
\text { Repair Shop." Added the following sentence } \\
\text { after sentence \#2, "The K-1 system also } \\
\text { exhausts air from the manipulator repair } \\
\text { shop." }\end{array}$ & C \\
\hline 19 & $\begin{array}{l}\text { 2.6.1.3, K-3 HVAC Supply and Exhaust System, } \\
\text { Pg 2-20, Para } 7 \text {, Question on entire paragraph: What } \\
\text { happened to filtered, heated, or cooled? (See K-1) }\end{array}$ & & $\begin{array}{l}\text { Section \# changed to } 2.6 .2 .3 \text {. The following } \\
\text { sentences added to paragraph 1, of section } \\
2.6 .2 .3 \text {. The supply air is filtered by } 8 \% \\
\text { and } 80 \% \text { efficiency NBS filters, heated or } \\
\text { cooled appropriately and distributed through } \\
\text { a duct network to the area shown on the } \\
\text { airflow diagram in Figure 2-9. }\end{array}$ & C \\
\hline 20 & $\begin{array}{l}\text { 2.6.1.3, K-3 HVAC Supply and Exhaust System, } \\
\text { Pg 2-20, Para 9, Ln } 3 \text { : Change to: "... the effluent } \\
\text { from the cells is combined with the Canyon..." An } \\
\text { additional comment is: In addition to the air being } \\
\text { drawn from the Canyon through the cells, a portion } \\
\text { of the air is exhausted through ducting in the } \\
\text { Canyon which is connected directly to the K-3 } \\
\text { exhaust duct. A damper in this duct automatically } \\
\text { controls the negative Canyon pressure. }\end{array}$ & & $\begin{array}{l}\text { Section \# is now } 2.6 .2 .3 \text {. } \\
\text { A) Changed "each cell" to "the cells." }\end{array}$ & C \\
\hline 21 & $\begin{array}{l}2.6 .1 .3, \mathrm{~K}-3 \text { HVAC Supply and Exhaust System, } \\
\text { Pg 2-21, Para 1, Ln } 4: \text { Change to: "...partitioned } \\
\text { from the bottom to near the top to direct air flow } \\
\text { upward through the separators and heaters." }\end{array}$ & & $\begin{array}{l}\text { Section \# is now 2.6.2.3. } \\
\text { Changed text to read "..partitioned from } \\
\text { the bottom to near the top to direct air } \\
\text { flow upward through the separators and } \\
\text { heaters and prevent water from flowing into } \\
\text { the HEPA section." }\end{array}$ & C \\
\hline
\end{tabular}




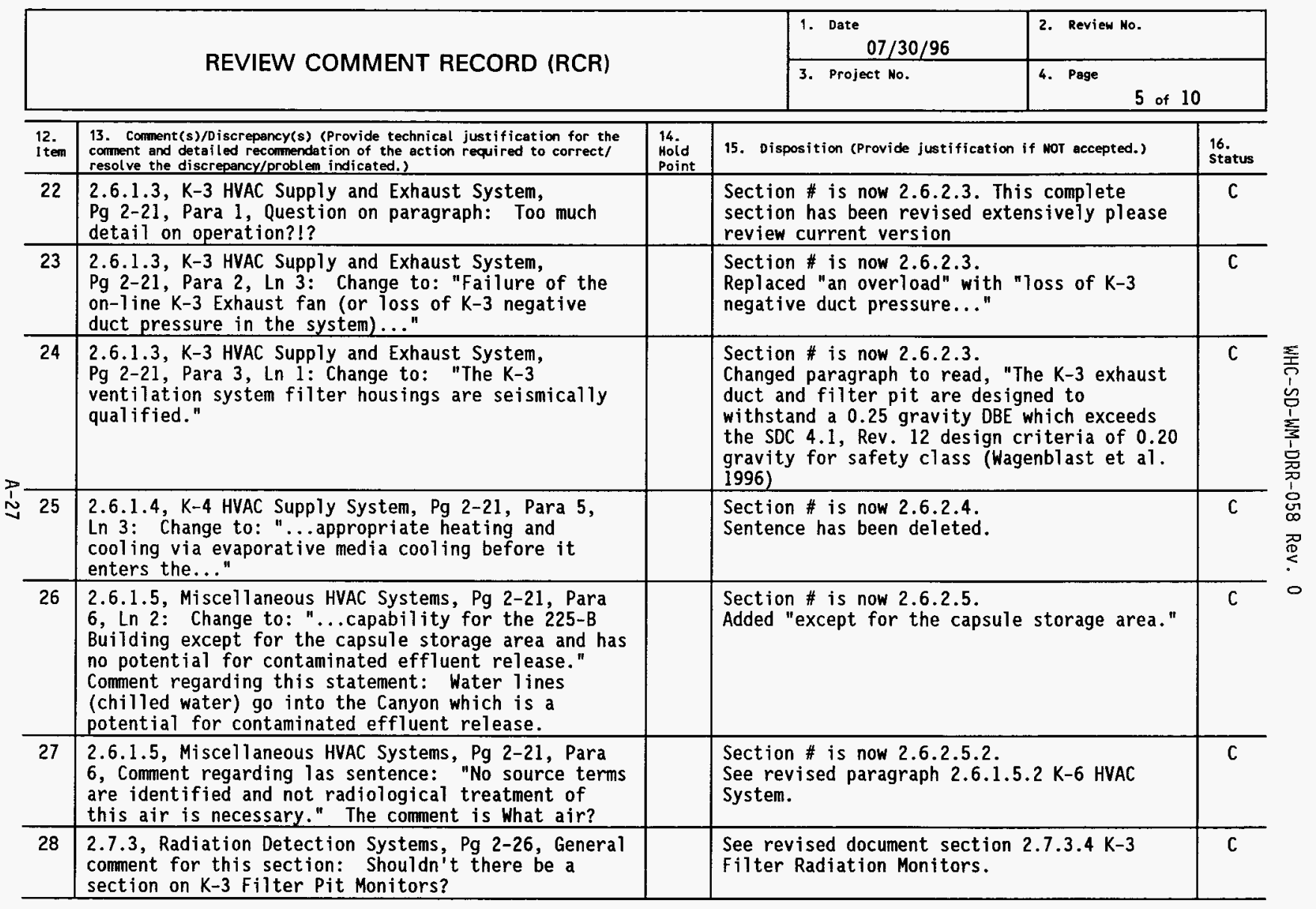




\begin{tabular}{|c|c|c|}
\hline & $\begin{array}{l}\text { 1. Date } \\
07 / 30 / 96\end{array}$ & 2. Review No. \\
\hline REVIEW COMMENT RECORD (RCR) & 3. Project No. & 4. Page \\
\hline
\end{tabular}

\begin{tabular}{|c|c|c|c|c|}
\hline $\begin{array}{l}12 . \\
\text { Item }\end{array}$ & $\begin{array}{l}\text { 13. Comment( }(s) / 0 \text { iscrepancy(s) (Provide technical justification for the } \\
\text { comment and detailed recommendation of the action required to correct/ } \\
\text { resolve the discrepancy/problem indicated.) }\end{array}$ & $\begin{array}{l}14 . \\
\text { Hold } \\
\text { Point }\end{array}$ & 15. Disposition (Provide justification if NOT accepted.) & $\begin{array}{l}16 . \\
\text { Status }\end{array}$ \\
\hline 29 & $\begin{array}{l}\text { 2.8.2, Compressed Air System, } \mathrm{Pg} 2-28 \text {, Para } 3 \text {, } \\
\text { Comment on first sentence: "Compressed air for the } \\
225-\mathrm{B} \text { Building is supplied by two compressors..." } \\
\text { This is almost obsolete. One is deactivated as of } \\
7 / 30 / 96 \text {. }\end{array}$ & & $\begin{array}{l}\text { See complete revision to this section. Two } \\
\text { leased compressors are identified. }\end{array}$ & C \\
\hline 30 & $\begin{array}{l}\text { 2.8.2, Compressed Air System, } \mathrm{Pg} 2-28 \text {, Para } 3 \text {, } \\
\text { Comment on entire paragraph: } 100 \mathrm{psi} \text { air is reduced } \\
\text { to } 25 \text { psi "instrument" air locally as needed in most } \\
\text { cases. }\end{array}$ & & $\begin{array}{l}\text { See complete revision to this section. Last } \\
\text { sentence addresses distribution at } 25 \text { psi. }\end{array}$ & C \\
\hline 31 & $\begin{array}{l}\text { 2.8.2, Compressed Air System, } \mathrm{Pg} 2-28, \text { Para } 4, \operatorname{Ln} 2: \\
\text { Change to: ".. level detectors and the K-3 Filter } \\
\text { housing sump level monitors (air bubblers), and } \\
\text { other control instruments." }\end{array}$ & & $\begin{array}{l}\text { See complete revision to this section. } \\
\text { Discussion on level monitors has been } \\
\text { eliminated. }\end{array}$ & C \\
\hline 32 & $\begin{array}{l}\text { 2.8.4.3.2, Deionized Water System, Pg 2-30, Para } 4 \text {, } \\
\text { Ln 5: Change to: "...during B Plant deionized water } \\
\text { outage system outages and fire fog in F Cel1." }\end{array}$ & & $\begin{array}{l}\text { See revised section, fire fog term not } \\
\text { needed. Section does address use for fire } \\
\text { suppression in } F \text { Cell. }\end{array}$ & $\mathrm{C}$ \\
\hline 33 & 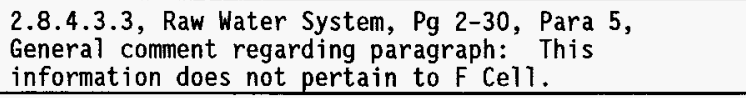 & & $\begin{array}{l}\text { There is no mention of } F \text { Cell in the current } \\
\text { revision of this section. }\end{array}$ & $\mathrm{C}$ \\
\hline 34 & $\begin{array}{l}\text { 2.9, Auxiliary Systems and Support Buildings, } \\
\text { Pg 2-31, Bullet 2: Change to: "225-BA, K-1 Filter } \\
\text { Building" }\end{array}$ & & $\begin{array}{l}\text { Deleted "Pit Encapsulation Facility" from } \\
\text { bullet. Bullet now reads, "225-BA, K-1 } \\
\text { Filter Building." }\end{array}$ & C \\
\hline 35 & $\begin{array}{l}\text { 2.9.1, TK-100, Low-Level Waste Tank/Pit, Pg 2-31, } \\
\text { Para } 2 \text {, Ln } 4: \text { Change to: " } \ldots \text { and accumulated 1iquid } \\
\text { in the sump of the K-3 Filter unit." }\end{array}$ & & $\begin{array}{l}\text { Change had been made in a previous comment } \\
\text { disposition. }\end{array}$ & C \\
\hline 36 & 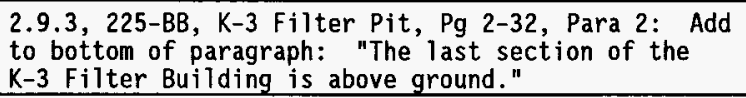 & & $\begin{array}{l}\text { Added sentence to end of paragraph, "The } \\
\text { last section of the K-3 Filter Building is } \\
\text { above ground." }\end{array}$ & C \\
\hline 37 & $\begin{array}{l}\text { 2.9.4, 226-BC, WESF Compressor Building, Pg 2-32, } \\
\text { Para 3, Ln 8: Change to: "... Which houses the } \\
\text { Compressed Air System Receiver Tank and the air } \\
\text { dryer." }\end{array}$ & & $\begin{array}{l}\text { Previously addressed in another comment. } \\
\text { Last sentence in paragraph reads "... Which } \\
\text { houses the compressed air system receiver } \\
\text { tank and the primary dryer," }\end{array}$ & C \\
\hline
\end{tabular}

A-6400-090.1 (03/92) WeF011 


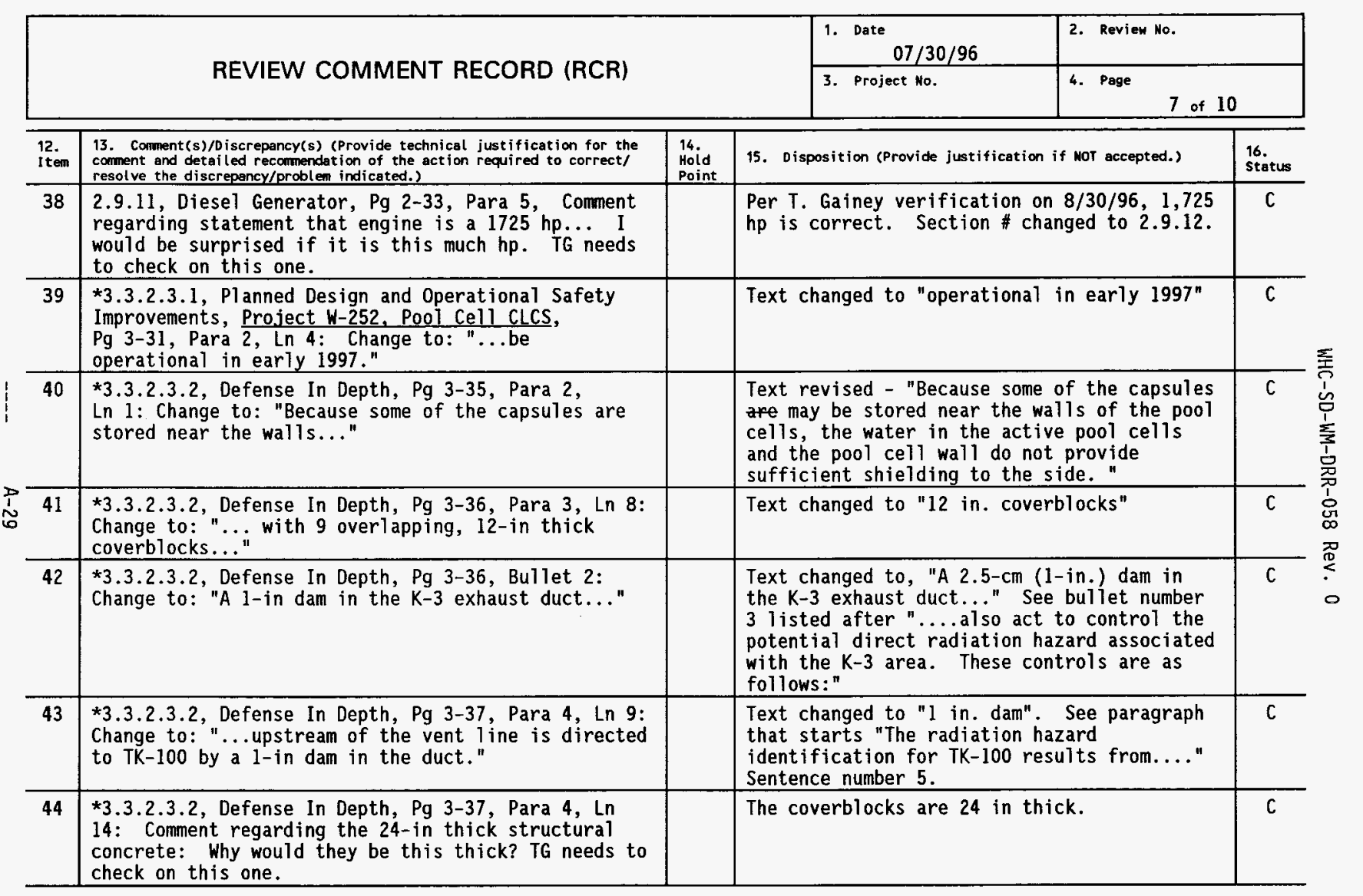




\begin{tabular}{|l|l|l|}
\hline \multirow{2}{*}{ REVIEW COMMENT RECORD (RCR) } & $\begin{array}{l}\text { Date Review No. } \\
07 / 30 / 96\end{array}$ \\
\cline { 2 - 3 } & 3. Project No. & 4. Page \\
\end{tabular}

\begin{tabular}{|c|c|c|c|c|}
\hline $\begin{array}{l}12 . \\
\text { I ten }\end{array}$ & $\begin{array}{l}\text { 13. Comment(s)/Discrepency(s) (Provide technical justification for the } \\
\text { comment and detailed reconmendation of the action required to correct/ } \\
\text { resolve the discrepancy/problem indicated.) }\end{array}$ & $\begin{array}{l}14 . \\
\text { Hold } \\
\text { Point } \\
\end{array}$ & 15. Disposition (Provide justification if NOT accepted.) & $\begin{array}{l}\text { 16. } \\
\text { Status }\end{array}$ \\
\hline 45 & $\begin{array}{l}\text { *3.3.2.3.2, Defense In Depth, Pg } 3-42 \text {, Para } 3 \text {, Ln } \\
11: \text { Change to: "...the smal1 but significant amount } \\
\text { of ventilation provided by the TK- } 100 \text { bubbler..." }\end{array}$ & & Text changed to TK-100 bubbler & C \\
\hline 46 & $\begin{array}{l}\text { *3.3.2.3.2, Defense In Depth, Pg 3-48, Table, Cell } \\
3 \text {, Column 1: Change to: "Alternate ventilation of } \\
\text { pool cell area..." }\end{array}$ & & $\begin{array}{l}\text { Spelling of ventilation corrected. See } \\
\text { Table 3-1. }\end{array}$ & C \\
\hline 47 & $\begin{array}{l}\text { *3.4.2.1.2.1, Scenario Development, Pg } 3-76 \text {, Bullet } \\
15: \text { Change to: "K-3 Filter housing is seismically } \\
\text { qualified;" }\end{array}$ & & $\begin{array}{l}\text { Under SSCs not designed for DBE, Bullet } 8 \\
\text { reads : K-3 HEPA filter housing to duct } \\
\text { connection }\end{array}$ & C \\
\hline 48 & $\begin{array}{l}\text { *3.4.2.1.2.1, Scenario Development, Pg 3-78, Para 1, } \\
\text { Ln 1: Spelling error: arise }\end{array}$ & & Text changed to "arise" & C \\
\hline 49 & $\begin{array}{l}\text { *3.4.2.1.2.1, Scenario Development, Pg } 3-78 \text {, Para } 1 \text {, } \\
\text { Ln } 2 \text { : Comment regarding awkward sentence: } \\
\text { "...filter box itself, with a subsequent? of the } \\
\text { inlet and outlet ducting." }\end{array}$ & & $\begin{array}{l}\text { Text changed to make sentence clearer } \\
\text { "...displacement of the filter housing } \\
\text { itself with a subsequent breach of the inlet } \\
\text { and outlet ducting. This breach could } \\
\text { result in a bypass of the of the filter } \\
\text { box..." }\end{array}$ & C \\
\hline 50 & $\begin{array}{l}\text { *3.4.2.3.1.1, Scenario Development, B Through E } \\
\text { Cells, Pg 3-89, Para } 3 \text {, Ln 5: Question regarding } \\
\text { (neoprene manipulator boots. Is this vinyl? }\end{array}$ & & Manipulator boots are neoprene. & C \\
\hline 51 & $\begin{array}{l}\text { *3.4.2.3.1.1, Scenario Development, K-3 Ventilation } \\
\text { System Response to a Hot Cel] Fire, Pg } 3-90 \text {, Bullet } \\
4: \text { Change to: "the K-1 exhaust fans would be } \\
\text { deactivated, leading to deactivation of the K-1 } \\
\text { supply and K-4 fan (as the pressure in the K-1 } \\
\text { exhaust duct approaches atmospheric)," }\end{array}$ & & $\begin{array}{l}\text { Text changed to "the K-1 exhaust fans would } \\
\text { be deactivated, leading to deactivation of } \\
\text { the K-1 supply and } K-4 \text { fan (as the pressure } \\
\text { in the K-1 exhaust duct approaches } \\
\text { atmospheric)" }\end{array}$ & $\mathrm{C}$ \\
\hline 52 & 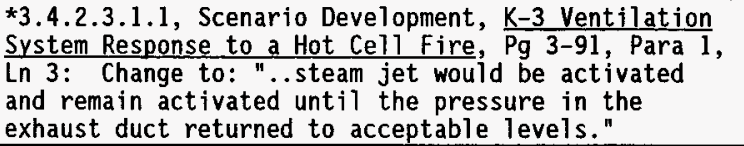 & & $\begin{array}{l}\text { Text changed from supply duct to exhaust } \\
\text { duct }\end{array}$ & C \\
\hline
\end{tabular}

A-6400-090.1 (03/92) WEF011 


\begin{tabular}{|l|l|l|}
\hline \multirow{2}{*}{ REVIEW COMMENT RECORD (RCR) } & $\begin{array}{l}\text { 1. Date } \\
07 / 30 / 96\end{array}$ \\
\cline { 2 - 3 } & 3. Project No. & 4. Page \\
\end{tabular}

12. 13. Corment(s)/Discrepancy(s) (Provide technical justification for the

Item comment and detailed reconmendation of the action required to correct/ resolve the discrepancy/problem indicated.)

53 *3.4.2.3.1.1, Scenario Development, K-3 Ventilation System Response to a Hot Cell Fire, Pg 3-91, Para 2, Ln 4: Troubled sentence: "...condition can be determined by estimating by comparing known filter failure..."

$54 \quad \star 3.4 .2 .3 .1 .3$, Consequence Analysis, Mitigated Condition, Pg 3-100, Para 5, Ln 5: Change to: "...the service gallery and operating gallery via manipulator ports while a fire in any of the hot cells..."

\begin{tabular}{|c|c|c|}
\hline $\begin{array}{l}14 . \\
\text { Hoid } \\
\text { Point }\end{array}$ & 15. Disposition (Provide justification if wot accepted.) & $\begin{array}{l}16 . \\
\text { status }\end{array}$ \\
\hline & Text change : "by estimating" was removed & C \\
\hline & $\begin{array}{l}\text { The sentence currently says that all hot } \\
\text { cells (including A Cell) can release } \\
\text { contamination to the Operating Gallery. F } \\
\text { and G Cells do not release contamination } \\
\text { because a fire is prevented in those cells } \\
\text { through administrative controls. }\end{array}$ & $\mathrm{C}$ \\
\hline & 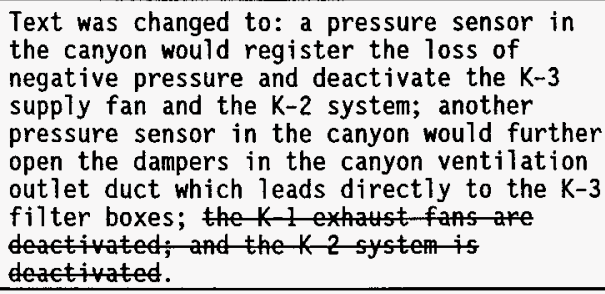 & C \\
\hline & $\begin{array}{l}\text { Text was changed to : High airflow through } \\
\text { the K-3 ventilation system could be caused } \\
\text { by instrumentation failure, allowing } \\
\text { multiple fans and the steam jet to run } \\
\text { simultaneously, or could be a result of } \\
\text { opening a flow path, such as the removal of } \\
\text { the Truckport cover block (leading to the } \\
\text { canyon) while the Truckport door is open to } \\
\text { environment. }\end{array}$ & C \\
\hline
\end{tabular}
1, Ln 6: Change to: "...filter boxes; and the K-2 


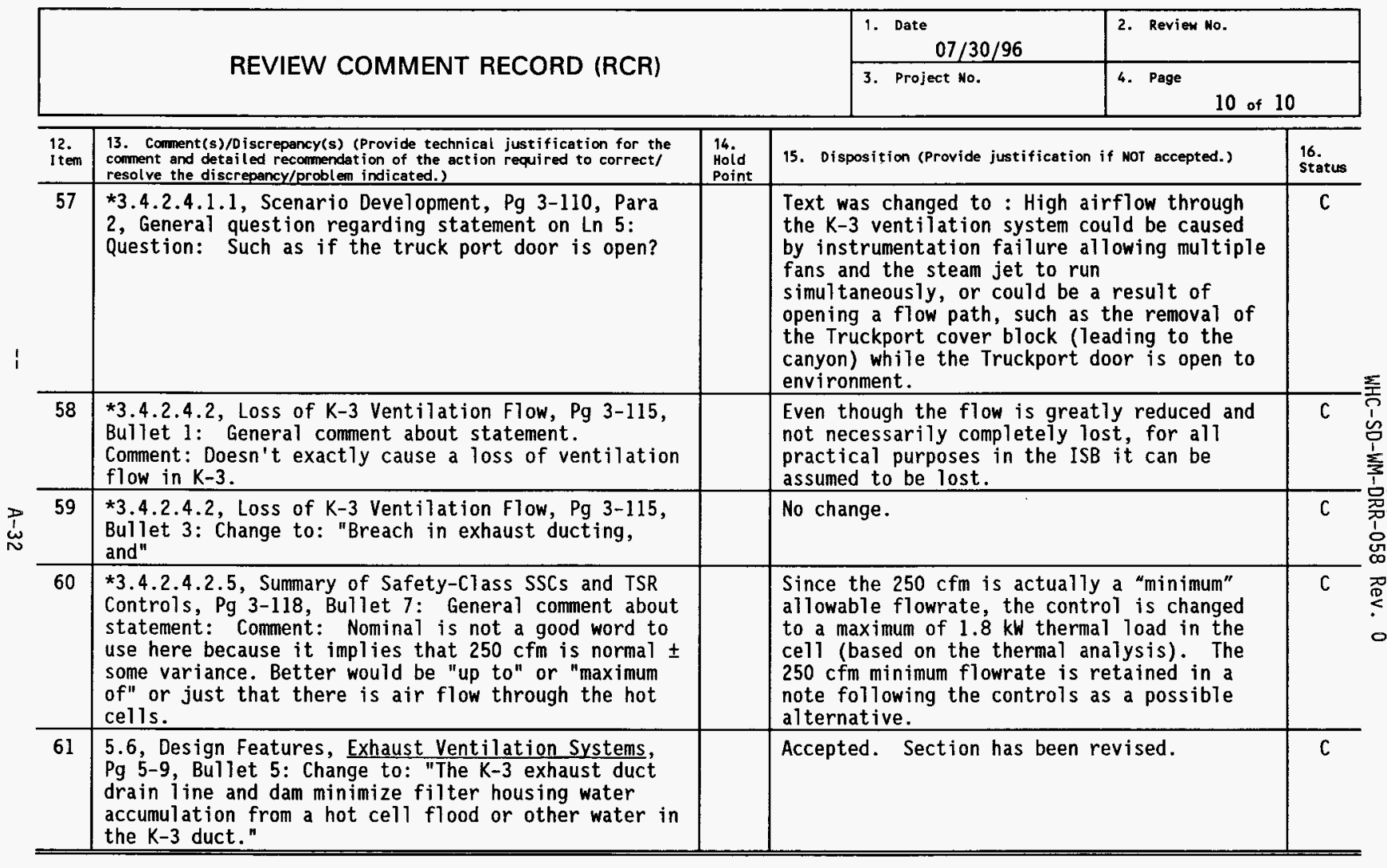

* Comments on this RCR for Chapter 3 were made from an older version of the ISB, dated July 15, 1996. 


\begin{tabular}{|l|l|l|}
\hline \multirow{2}{*}{ REVIEW COMMENT RECORD (RCR) } & $\begin{array}{l}\text { 1. Date } 07 / 29 / 96 \\
0 . \text { Review No. } \\
01\end{array}$ \\
\cline { 2 - 4 } & $\begin{array}{c}\text { 3. Project No. } \\
\text { WESF_ISB }\end{array}$ & $\begin{array}{l}\text { 4. Page } \\
1 \text { of } 4\end{array}$ \\
\hline
\end{tabular}

\begin{tabular}{l|l|l|l|l}
\hline 5. Document Mumber(s)/Title(s) & $\begin{array}{l}\text { 6. Program/Project/ } \\
\text { Building Number } \\
\text { WESF/ISB }\end{array}$ & $\begin{array}{l}\text { 7. Reviewer } \\
\text { M.A. HILL }\end{array}$ & $\begin{array}{l}\text { 8. Organization/Group } \\
\text { Tech Support Grp/QA }\end{array}$ & $\begin{array}{l}\text { Location/Phone } \\
\text { M0-206/6-5077 }\end{array}$ \\
\hline
\end{tabular}

17. Cominent Submittal Approval:

Organization Manager (Optional)
10. Agreenent with indicated compent Alsposition(s)
11. CLOSED

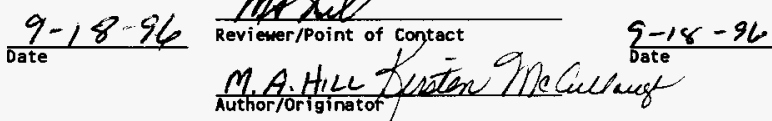

\begin{tabular}{|c|c|c|c|c|}
\hline $\begin{array}{l}12 . \\
1 \text { tem }\end{array}$ & $\begin{array}{l}\text { 13. Comment(s)/Discrepancy(s) (Provide technical justification for the } \\
\text { comment and detailed reconmendation of the action required to correct/ } \\
\text { resolve the discrepancy/problem indicated.) }\end{array}$ & $\begin{array}{l}14 . \\
\text { Hold } \\
\text { Point }\end{array}$ & 15. Disposition (Provide justification if NOT accepted.) & $\begin{array}{l}16 . \\
\text { status }\end{array}$ \\
\hline 1 & $\begin{array}{l}\text { In chapter } 6 \text {, neither Table 6-1 nor the text } \\
\text { references WHC-SP-1131, WHC QA Program and } \\
\text { Implementation PTan. SP-1131 is the QA Rule (10 CFR } \\
830.120 \text { ) implementation document for a11 WHC } \\
\text { facilities. }\end{array}$ & MAH & $\begin{array}{l}\text { TEXT WILL BE CHANGED Table 6-1 provides a } \\
1 \text { ist of requirements for QA under item \#8. } \\
\text { The QA document "WHC-SP-1131, West inghouse } \\
\text { Hanford Company Qual ity Assurance Program } \\
\text { and Implementation Plan, Rev. 1, S. S. } \\
\text { Moss, } 7 / 01 / 96 \text {, wi } 11 \text { be added to the } 1 \text { ist } \\
\text { under Applicable Westinghouse Hanford } \\
\text { Company Control Manuals. } \\
\text { The CFRs have been eliminated and a } \\
\text { reference to the WESF SRIDS has ben entered } \\
\text { since the SRID document identifies the } \\
\text { required CFRS. }\end{array}$ & \\
\hline
\end{tabular}




\begin{tabular}{|c|c|c|}
\hline & $\begin{array}{l}\text { 1. Date } \\
07 / 29 / 96 \\
\end{array}$ & $\begin{array}{r}\text { 2. Review No. } \\
01 \\
\end{array}$ \\
\hline REVIEW COMMENT RECORD (RCR) & $\begin{array}{l}\text { 3. Project No. } \\
\text { WESF_ISB }\end{array}$ & 4. Page 2 of 4 \\
\hline
\end{tabular}

\begin{tabular}{|c|c|c|c|c|}
\hline $\begin{array}{l}12 . \\
\text { It ten }\end{array}$ & $\begin{array}{l}\text { 13. Conment(s)/Discrepancy(s) (Provide technical justification for the } \\
\text { comment and detailed recommendat ion of the act ion required to correct/ } \\
\text { resolve the discrepancy/problem indicated.) }\end{array}$ & $\begin{array}{l}14 . \\
\text { Hold } \\
\text { Point }\end{array}$ & 15. Disposition (Provide justification if NOT accepted.) & $\begin{array}{l}16 . \\
\text { status }\end{array}$ \\
\hline 2 & $\begin{array}{l}\text { In chapter } 6 \text {, neither Table } 6-1 \text { nor the text } \\
\text { references the facility specific document, } \\
\text { WHC-CM-5-6, Section 10, which contains the Quality } \\
\text { Policies (QAPP) for our facility. This document } \\
\text { along with the S/RIDS for our facility are the basis } \\
\text { for our compliance with QA Rule programmatic and } \\
\text { compliance requirements. }\end{array}$ & MAH & $\begin{array}{l}\text { Facility specific documentation was not } \\
\text { identified because of the statements that } \\
\text { have been written in the } 3009 \text { standard. For } \\
\text { instance in } 1 \text {, QA, Chapter } 14,3009 \text { states } \\
\text { "This chapter is not intended to be the } \\
\text { vehicle for review and approval of the } \\
\text { quality assurance program. It is intended } \\
\text { to describe the essential features of the } \\
\text { program as it relates to facility safety." } \\
\text { Additiona1ly, I } 3 \text {, Chapter } 14 \text {, } 3009 \text { states } \\
\text { "Discussions can be brief and are limited to } \\
\text { summaries of the major features of the } \\
\text { programmatic commitment to the safety } \\
\text { basis." Consequently, since this is an ISB } \\
\text { and not an FSAR it was decided that the } \\
\text { upper tier control manuals would be used to } \\
\text { "briefly describe" the "essential features," } \\
\text { and provide "summaries of the major } \\
\text { features," Audits would ident ify the } \\
\text { specific procedures/programs and whether or } \\
\text { not the site quality assurance requirements } \\
\text { have been met. } \\
\text { TEXT WILL BE CHANGED, The SRIDS document is } \\
\text { referenced at the beginning of Chapter } 6 \text {. } \\
\text { The reference will be changed to reflect } \\
\text { complete reference information as follows: } \\
\text { Waste Encapsulation and Storage Facility } \\
\text { Standards/Requirements Identification } \\
\text { Document, WHC-SD-MP-SRID-007, Rev. } 0 \text {, May } 9 \text {, } \\
\text { l996, K. A. Jennings-Mills. }\end{array}$ & \\
\hline
\end{tabular}




\begin{tabular}{|l|l|l|}
\hline \multirow{2}{*}{ REVIEW COMMENT RECORD (RCR) } & $\begin{array}{l}\text { 1. Date Review No. } \\
01\end{array}$ \\
\cline { 2 - 4 } & $\begin{array}{c}\text { 3. Project No. } \\
\text { WESF_ISB }\end{array}$ & $\begin{array}{c}\text { 4. Page } \\
3 \text { of } 4\end{array}$ \\
\hline
\end{tabular}

\begin{tabular}{|c|c|c|c|c|}
\hline Item & $\begin{array}{l}\text { 13. Comment( }(s) / 0 \text { iscrepancy(s) (Provide technical justification for the } \\
\text { comment and detailed recomnendation of the action required to correct/ } \\
\text { resolve the discrepancy/problem indicated.) }\end{array}$ & $\begin{array}{l}\text { 16. } \\
\text { Hoid } \\
\text { Point }\end{array}$ & 15. Disposition (Provide justification if MOT accepted.) & $\begin{array}{l}\text { 16. } \\
\text { status }\end{array}$ \\
\hline 3 & $\begin{array}{l}\text { Section } 6.8 \text { of Chapter } 6 \text { of the ISB contains general } \\
\text { statements concerning compliance with various } \\
\text { aspects of a quality program, but no WESF specifics } \\
\text { are included. In review of requirements, it seems } \\
\text { that we are not constructing a QA section that } \\
\text { follows the suggested format of DOE-STD-3009-94, nor } \\
\text { do we seem to follow the direction indicated by } \\
\text { WHC-CM-4-46, Section } 9 \text {. I could not identify what } \\
\text { source requirements we are applying to the } \\
\text { development and documentation of the required } \\
\text { Quality Assurance section of this ISB. The } \\
\text { information provided in } 6.8 \text { is generic and provides } \\
\text { not specifics. Help me understand the fundamental } \\
\text { requirements concerning what we include in our ISB. }\end{array}$ & MAH & 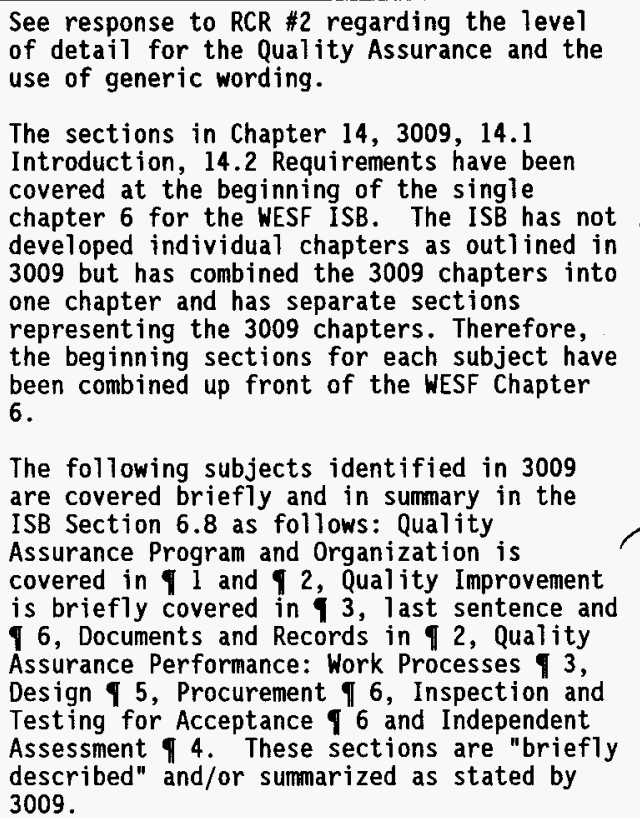 & \\
\hline
\end{tabular}




\begin{tabular}{|l|l|l|}
\hline \multirow{2}{*}{ REVIEW COMMENT RECORD (RCR) } & $\begin{array}{l}\text { 1. Date } 07 / 29 / 96 \\
0 . \text { Review No. } \\
01\end{array}$ \\
\cline { 2 - 4 } & $\begin{array}{c}\text { 3. Project No. } \\
\text { WESF_ISB }\end{array}$ & $\begin{array}{l}\text { 4. Page } \\
4 \text { of } 4\end{array}$ \\
\hline
\end{tabular}

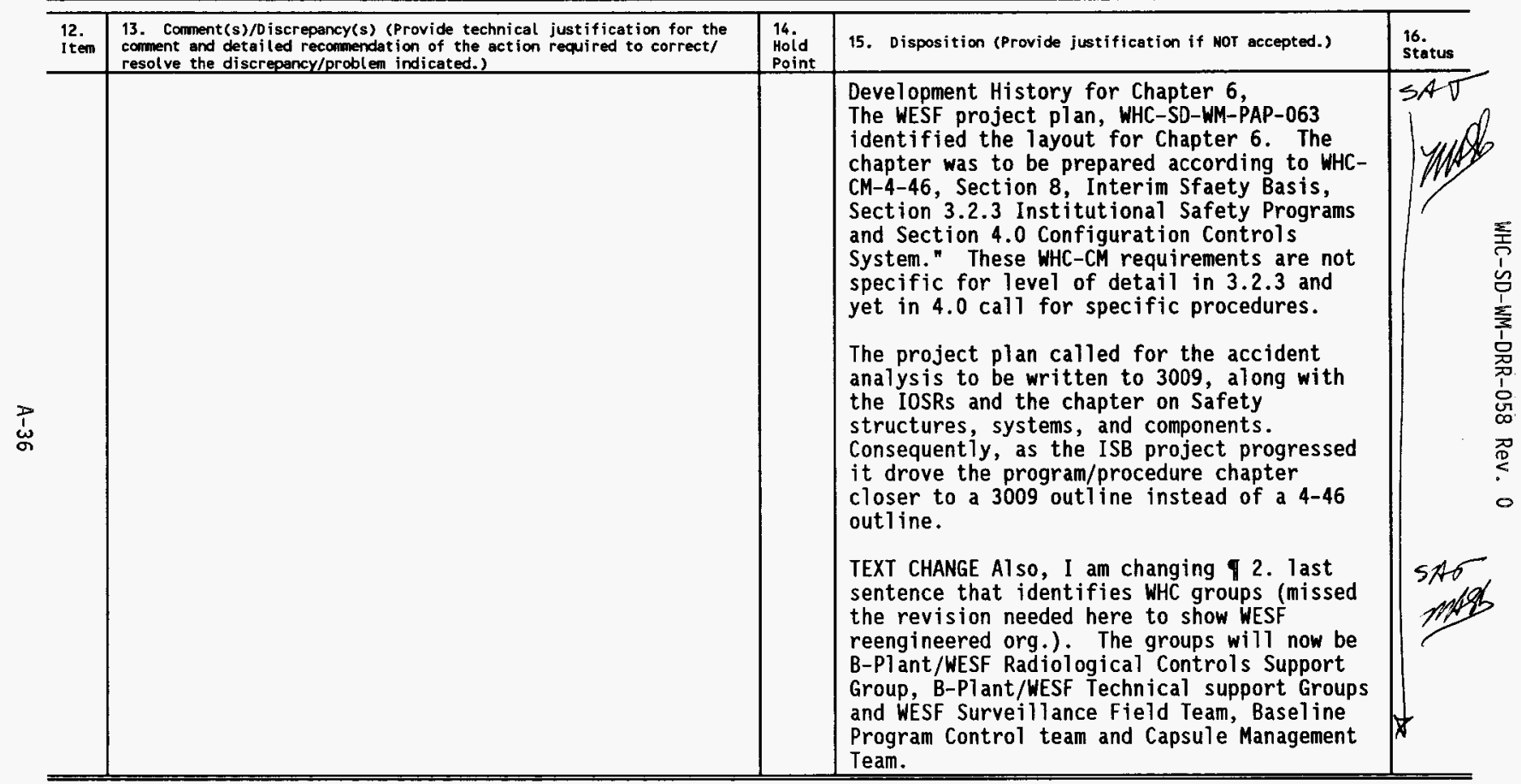




\begin{tabular}{|l|l|l|}
\hline \multirow{2}{*}{ REVIEW COMMENT RECORD (RCR) } & 1. Date & 2. Review No. \\
\cline { 2 - 3 } & 3. Project No. & 4. Page 1 of $\not 2 z$ \\
\hline
\end{tabular}

\begin{tabular}{l|l|l|l|l}
\hline 5. Document Number(s)/Title(s) & $\begin{array}{l}\text { 6. Program/Project/ } \\
\text { Building Number } \\
\text { WESF/225B }\end{array}$ & $\begin{array}{l}\text { 7. Reviewer } \\
\text { David W. Mertz }\end{array}$ & $\begin{array}{l}\text { 8. Organization/Group } \\
\text { Deactivation Support }\end{array}$ & $\begin{array}{l}\text { M0400/8/200E } \\
372-0359\end{array}$ \\
\hline
\end{tabular}

17. Comment Submittal Approval:

Organization Manager (optional)
10. Agreement with indicated comment disposition(s)

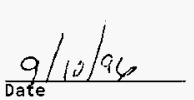

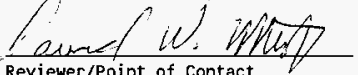

Reviewer/Point of contact

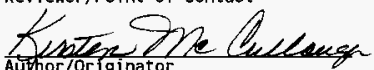

11. CLOSED

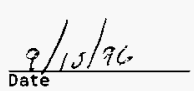

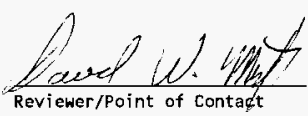

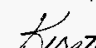

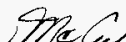

Aythorforiginator

12. 13. Corment(s)/Discrepancy(s) (Provide technical justification for the

Item coment and detailed recomendation of the action required to correct/ resolve the discrepancy/problem indicated.)

\begin{tabular}{|l|l|}
14. \\
Hold \\
Point
\end{tabular}
$\underset{\vec{⿱}}{\stackrel{v}{v}} \quad$ accident analyses.

1. Section 6.4.2, I 1, sentence \#2, (1) Delete the word "results" after "The FHA ..... (2) add " $s$ " to the word "describe." (3) replace; with a comma. (4) in sentence \#3 delete the word "results" after The

2. Section 6.4.2.1 I 1 , sentence \#1, delete the word "respond" after The WHC fire protection program is designed to protect against and/or... and add "provide direction for responding..."

3. Section 6.4.2.2, Item 1. after I 1 , End the first sentence at "and interpretations." Begin a second sentence by inserting the following words in front of the word providing. "They are also responsible for"

4. Section 6.4.2.2, Item 3, sentence \#l, delete the words fire suppression and insert "of fire suppression systems" after the words repair activities.

5. Section 6.4.2.2, I \#5, Sentence \#1, begins with "The HFD....." delete the word routinely.

(1) Revisions have been made as stated in the RCR. (2) Revisions have been made as stated in the RCR. (3) No change, Tech. Editing usage of semi colon is per WHC manua1. (4) Revisions have been made as stated.

Revisions have been made as stated in the RCR.

Revisions have been made as stated in the RCR.

Revisions have been made as stated in the RCR.

Revisions have been made as stated in the RCR. 


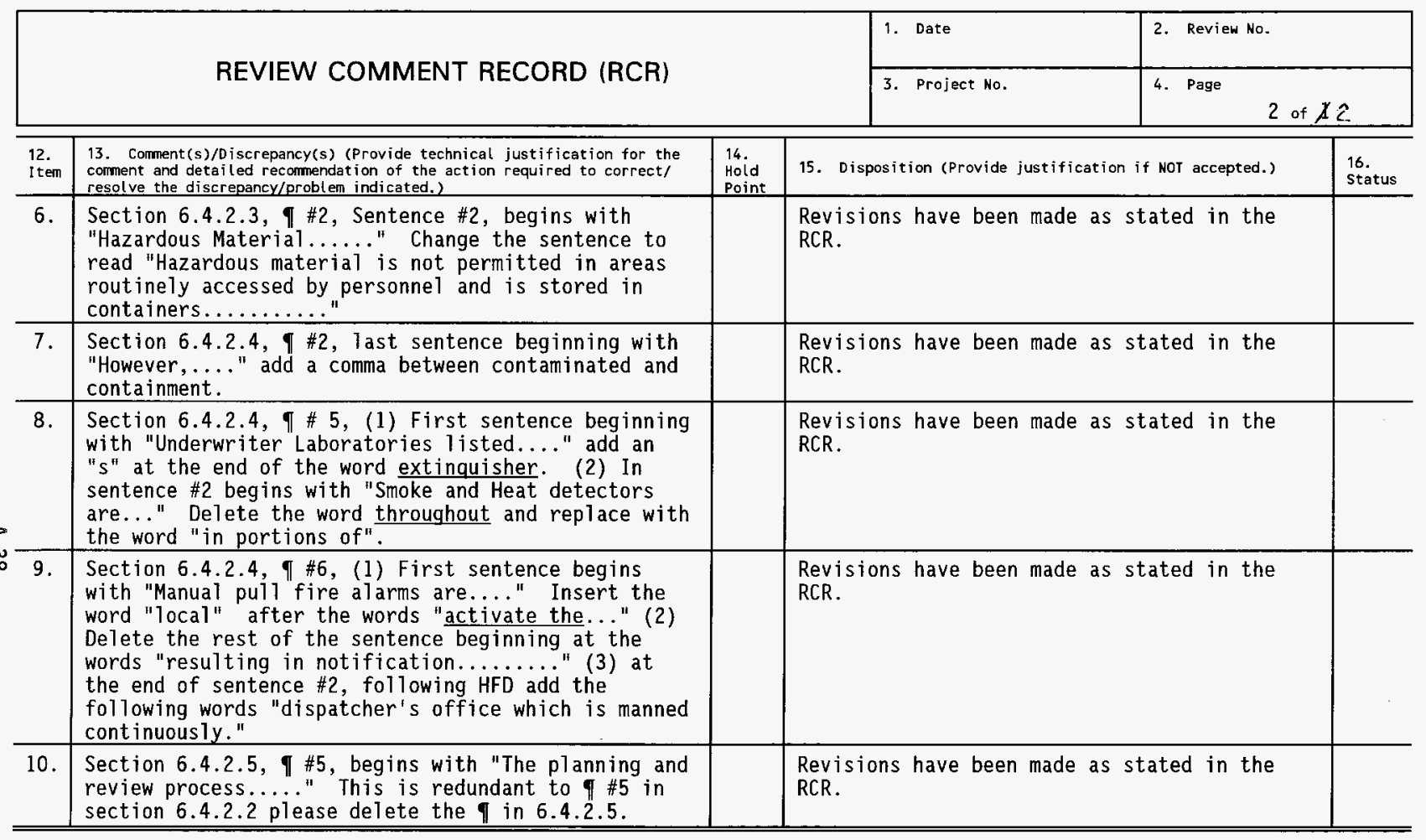




\section{REVIEW COMMENT RECORD (RCR)}

\begin{tabular}{|l|l|}
\hline $\begin{array}{l}\text { 1. Date } 8 / 07 / 96 \\
\text { 3. Project No. } \\
\text { WESF ISB }\end{array}$ & 2. Review No. \\
\hline
\end{tabular}

\begin{tabular}{l|l|l|l|l}
\hline 5. Document Nunber(s)/Title(s) & $\begin{array}{l}\text { 6. Program/Project/ } \\
\text { Building Mumber } \\
\text { WESF/225B }\end{array}$ & $\begin{array}{l}\text { 7. Reviewer } \\
\text { Steven K. Meyer }\end{array}$ & $\begin{array}{l}\text { 8. Organization/Group } \\
\text { Emergency } \\
\text { Preparedness }\end{array}$ \\
\begin{tabular}{l} 
WHC-SD-WM-ISB-009 \\
\hline
\end{tabular}
\end{tabular}

17. Comment Submittal Approval:

Organization Manager (Optional)
10. Agreement with indicated coment disposition(s)

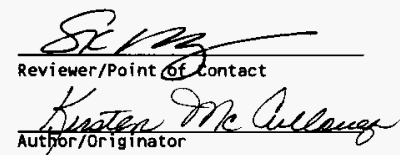

11. CLOSED

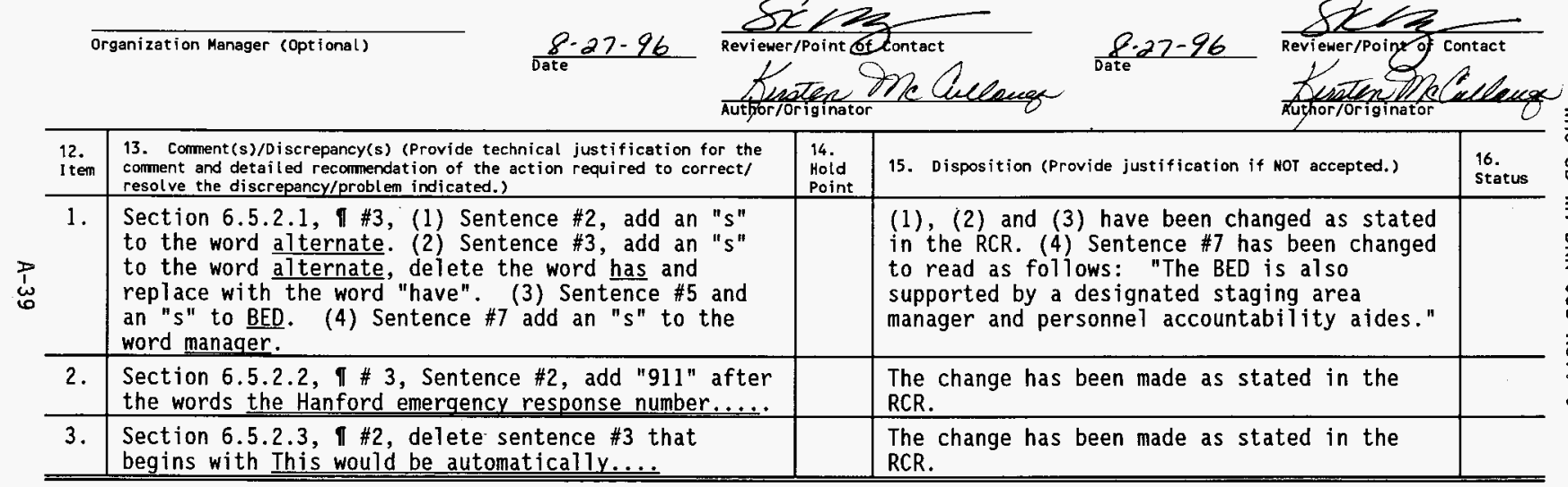


WHC-SD-WM-DRR-058 Rev. 0

This page intentionally left blank. 


\begin{tabular}{|l|l|l|}
\hline \multirow{2}{*}{ REVIEW COMMENT RECORD (RCR) } & 1. Date & Review No. \\
\cline { 2 - 3 } & 3. Project No. & 4. Page \\
\end{tabular}

\begin{tabular}{|c|c|c|c|c|}
\hline 5. Document Number(s)/title(s) & $\begin{array}{l}\text { 6. Program/Project/ } \\
\text { Bui lding Number }\end{array}$ & 7. Reviewer & 8. Organization/Group & 9. Location/Phone \\
\hline WHC-SD-WM-ISB-009, Rev 0 & WESF / 225B & $\begin{array}{l}\text { K. A. Jennings- } \\
\text { Mills }\end{array}$ & $\begin{array}{l}\text { 16E00/WESF Baseline } \\
\text { Control }\end{array}$ & M0-863/372-0101 \\
\hline
\end{tabular}

17. Comment Submittal Approval:

Organization Manager (optional) $\frac{9-25-96}{\text { Date }}$

K. A. Jennings-Mills

Reviewer/Point of Contact

11. CLOSED

\section{Bgthor/originator}

\begin{tabular}{|c|c|c|c|c|}
\hline $\begin{array}{l}12 . \\
\text { I tem }\end{array}$ & $\begin{array}{l}\text { 13. Comment(s)/D iscrepancy(s) (Provide technical justification for the } \\
\text { comment and detailed recommendation of the act ion required to correct/ } \\
\text { resolve the discrepancy/problem indicated.) }\end{array}$ & $\begin{array}{l}14 . \\
\text { Hoid } \\
\text { Point }\end{array}$ & 15. Disposition (Provide justification if NOT accepted.) & $\begin{array}{l}16 . \\
\text { status }\end{array}$ \\
\hline 1 & $\begin{array}{l}\text { 1.0, Introduction and Summary, Pg } 1-1 \text {, para } 3 \text {, } \\
\text { Ln 1: Change to: "Since the disposition for } \\
\text { cesium..." }\end{array}$ & & $\begin{array}{l}\text { Text changed to read "Since the disposition } \\
\text { for cesium..." }\end{array}$ & C \\
\hline 2 & $\begin{array}{l}\text { 1.1, Purpose, Pg 1-1, para 1, Ln 2: Change to: } \\
\text { "WHC-CM-4-46, Safety Analysis Manual, Section } \\
8.0 \ldots \text { ". }\end{array}$ & & $\begin{array}{l}\text { Text changed to read "WHC-CM-4-46, Safety } \\
\text { Analysis Manual, Section } 8.0 . . . "\end{array}$ & C \\
\hline 3 & $\begin{array}{l}\text { 1.1, Purpose, Pg 1-1, para 2, Ln 4: Change to: } \\
\text { "WHC-CM-1-5, Standard Operating Procedures, Section } \\
\text { 7.3..." }\end{array}$ & & $\begin{array}{l}\text { Text changed to read "WHC-CM-1-5, Standard } \\
\text { Operating Procedures, Section 7.3..." }\end{array}$ & C \\
\hline 4 & $\begin{array}{l}\text { 1.3.1, Current Mission, Pg } 1-3 \text {, para } 3, \operatorname{Ln} 1: \\
\text { Change to: "The current WESF mission is to safety } \\
\text { and compliantly receive and store..." }\end{array}$ & & $\begin{array}{l}\text { Text changed to read "The current WESF } \\
\text { mission is to receive and store the cesium } \\
\text { and strontium capsules that were } \\
\text { manufactured at WESF in a safe manner and in } \\
\text { compliance with all applicable rules and } \\
\text { regulations." }\end{array}$ & C \\
\hline 5 & $\begin{array}{l}\text { 1.3.1, Current Mission, Pg 1-3, bullet } 4 \text {, Ln 2: } \\
\text {...capitalize HAZOP... }\end{array}$ & & $\begin{array}{l}\text { Text changed to read "evaluated in the WESF } \\
\text { HAZOP..." }\end{array}$ & C \\
\hline 6 & $\begin{array}{l}\text { 1.3.2, Status, } \mathrm{Pg} 1-4 \text {, para } 2, \ln 6: \text { Change to: } \\
\text { "..refurbishment of most of the ceils' cerium. } \\
\text { windows." }\end{array}$ & & $\begin{array}{l}\text { Text has been changed, comment no longer } \\
\text { valid. }\end{array}$ & C \\
\hline
\end{tabular}




\begin{tabular}{|l|l|l|}
\hline \multirow{2}{*}{ REVIEW COMMENT RECORD (RCR) } & 1. Date & Review No. \\
\cline { 2 - 3 } & 3. Project No. & 4. Page 3 of 37 \\
\hline
\end{tabular}

\begin{tabular}{|c|c|c|c|c|}
\hline $\begin{array}{l}\text { 12. } \\
\text { Item }\end{array}$ & $\begin{array}{l}\text { 13. Corment(s)/Discrepancy(s) (Provide technical justification for the } \\
\text { comment and detailed recommendation of the action required to correct/ } \\
\text { resolve the discrepancy/problen indicated.) }\end{array}$ & $\begin{array}{l}\text { 14.id } \\
\text { Kold } \\
\text { Point }\end{array}$ & 15. Disposition (Provide justification if NOT accepted.) & $\begin{array}{l}16 . \\
\text { Status }\end{array}$ \\
\hline 7 & $\begin{array}{l}\text { 1.3.2, Scope, Pg } 1-4 \text {, para } 3 \text {, Ln 2: Change to: } \\
\text { "..decoupling of B Plant which after deactivation } \\
\text { wil no longer support WESF operations." }\end{array}$ & & $\begin{array}{l}\text { Text has been changed, comment no longer } \\
\text { valid. }\end{array}$ & C \\
\hline 8 & $\begin{array}{l}\text { 1.3.3, Major Modifications, Pg 1-4, para 5, Ln 2: } \\
\text { Change to: "...Pool Cell water cooling system and } \\
\text { reduce..." }\end{array}$ & & $\begin{array}{l}\text { Text has been changed, comment no longer } \\
\text { valid. }\end{array}$ & C \\
\hline 9 & $\begin{array}{l}\text { 1.3.3, Major Modifications, } \mathrm{Pg} 1-4, \text { para } 6, \operatorname{Ln} 3: \\
\text { Change to: "The pipe has a standard fire hose..." }\end{array}$ & & $\begin{array}{l}\text { Text has been changed, comment no longer } \\
\text { valid. }\end{array}$ & C \\
\hline 10 & 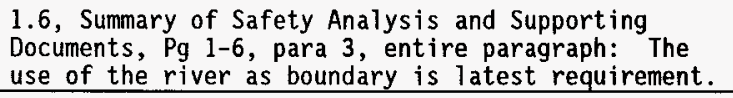 & & $\begin{array}{l}\text { Paragraph wording has changed to reflect } \\
\text { this. }\end{array}$ & C \\
\hline 11 & Table 1-1, Page 1-8, Last empty cell: Needs text. & & $\begin{array}{l}\text { Table has been deleted, comment no longer } \\
\text { valid. }\end{array}$ & C \\
\hline 12 & $\begin{array}{l}1.7 \text {, Conclusions, } \mathrm{Pg} 1-8 \text {, para } 2 \text {, Line } 2: \\
\text { Radiological dose consequences for a range... } \\
\text { (Entire sentence): EG not shown in Table } 1-1 \text {. }\end{array}$ & & $\begin{array}{l}\text { Table has been deleted along with associated } \\
\text { text, comment no longer valid. }\end{array}$ & C \\
\hline 13 & $\begin{array}{l}\text { 2.0, Facility Description, } P g \text { 2-1, para } 3, \operatorname{Ln} 3 \text { : } \\
\text { Change to: "...with their impact on safety." }\end{array}$ & & $\begin{array}{l}\text { Text changed to read "...with their impact } \\
\text { on safety." }\end{array}$ & $\mathrm{C}$ \\
\hline 14 & $\begin{array}{l}\text { 2.2, Requirements, } \mathrm{Pg} \mathrm{2-2,} \mathrm{para} \mathrm{2,} \mathrm{Bulleted} \mathrm{items:} \\
\text { Question. How do we know this is all? No DOE } \\
\text { Standards or Electrical. }\end{array}$ & & $\begin{array}{l}\text { The } 3009 \text { Standard calls out design codes and } \\
\text { standards etc. However, "not a } \\
\text { comprehensive listing of industry standards, } \\
\text { codes or criteria. SRIDs may be } \\
\text { referenced..." The major requirements have } \\
\text { been provided and SRIDs have been } \\
\text { referenced. }\end{array}$ & C \\
\hline
\end{tabular}




\begin{tabular}{|l|l|l|}
\hline \multirow{2}{*}{ REVIEW COMMENT RECORD (RCR) } & 2. Date Review No. \\
\cline { 2 - 3 } & 3. Project No. & 4 . Page 3 of 37 \\
\hline
\end{tabular}

\begin{tabular}{|c|c|c|c|c|}
\hline $\begin{array}{l}12 . \\
\text { Item }\end{array}$ & $\begin{array}{l}\text { 13. Comment(s)/Discrepancy(s) (Provide technical justification for the } \\
\text { corment and detailed recommendation of the action required to correct/ } \\
\text { resolve the discrepancy/problem indicated.) }\end{array}$ & $\begin{array}{l}\text { 14. } \\
\text { Hold } \\
\text { Point }\end{array}$ & 15. Disposition (Provide justification if NOT accepted.) & $\begin{array}{l}16 . \\
\text { Status }\end{array}$ \\
\hline 15 & $\begin{array}{l}\text { Figure 2-4, 225-B, First Floor Plan, Pg F-4, Small } \\
\text { room next to Pool Cell Monitoring Room should be } \\
\text { labeled Pool Cell Entry Airlock; Area to the right } \\
\text { of the elevator and below the office should be } \\
\text { labeled Supervisor's Control Area; Area right of the } \\
\text { up stairs and below the change room should be } \\
\text { labeled SWP Lobby/Laundry; There should be no door } \\
\text { on the B-C pass through in the hot cells; There } \\
\text { should be lines designating a furnace and rack } \\
\text { between B-C. }\end{array}$ & & $\begin{array}{l}\text { Change to Figure 2-4, 225-B, First Floor } \\
\text { Plan, Pg F-4, the figure was changed as } \\
\text { follows. The small room next to Pool Cell } \\
\text { Monitoring Room is labeled "Airlock"; the } \\
\text { area to the right of the elevator and below } \\
\text { the office is labeled "Supervisory Control } \\
\text { Area"; the area right of the up stairs and } \\
\text { below the change room is labeled "SWP } \\
\text { Lobby/Laundry"; the door on the B-C pass } \\
\text { through in the hot cells has been } \\
\text { eliminated; Lines are not added designating } \\
\text { a furnace and rack between B-C. The added } \\
\text { detail is not needed to support the } \\
\text { analysis. }\end{array}$ & C \\
\hline 16 & $\begin{array}{l}\text { 2.3.1.4, WESF Standby, } \mathrm{Pg} 2-4 \text {, para } 3, \operatorname{Ln} 7: \text { Change } \\
\text { to: "Cleanup efforts included refurbishment of..." }\end{array}$ & & $\begin{array}{l}\text { Text changed to read "Cleanup efforts } \\
\text { included refurbishment of..." }\end{array}$ & C \\
\hline 17 & $\begin{array}{l}2.3 .1 .5 \text {, Beneficial Capsule Use, } \mathrm{Pg} 2-4 \text {, para } 4 \text {, } \\
\text { Ln 2: Change to: "...for use as radiation sources." }\end{array}$ & & $\begin{array}{l}\text { Text changed to read "...for use as } \\
\text { radiation sources." }\end{array}$ & C \\
\hline 18 & $\begin{array}{l}\text { 2.3.1.5, Beneficial Capsule Use, } \mathrm{Pg} 2-4 \text {, para } 4, \mathrm{Ln} \\
\text { 6: Change to: "Consequently, disposition is being } \\
\text { determined." }\end{array}$ & & The sentence has been deleted. & C \\
\hline 19 & $\begin{array}{l}\text { 2.3.2, Current Mission, } \mathrm{Pg} 2-4 \text {, para } 5, \operatorname{Ln} 1 \text { : Change } \\
\text { to: "The current WESF mission is to safely and } \\
\text { compliantly receive..." }\end{array}$ & & $\begin{array}{l}\text { Text changed to read "The current WESF } \\
\text { mission is to receive and store the cesium } \\
\text { and strontium capsules that were } \\
\text { manufactured at WESF in a safe manner and in } \\
\text { compliance with all applicable rules and } \\
\text { regulations." }\end{array}$ & C \\
\hline 20 & $\begin{array}{l}\text { 2.3.2, Current Mission, Pg 2-5, Third bullet, Ln 2: } \\
\text { Capitalize HAZOP }\end{array}$ & & $\begin{array}{l}\text { Text changed to read "evaluated in the WESF } \\
\text { HAZOP (Siemer 1995) }\end{array}$ & C \\
\hline
\end{tabular}




\section{REVIEW COMMENT RECORD (RCR)}

\begin{tabular}{|l|l|}
\hline 1. Date & 2. Review No. \\
\hline 3. Project No. & 4. Page 4 of 37 \\
\hline
\end{tabular}

\begin{tabular}{|c|c|c|c|c|}
\hline $\begin{array}{l}12 . \\
\text { I tem }\end{array}$ & $\begin{array}{l}\text { 13. Comment(s)/Discrepancy(s) (Provide technical justification for the } \\
\text { corment and detailed recommendation of the action required to correct/ } \\
\text { resolve the discrepancy/problem indicated.) }\end{array}$ & $\begin{array}{l}14 . \\
\text { Hoid } \\
\text { Point }\end{array}$ & 15. Disposition (Provide justification if NOT accepted.) & $\begin{array}{l}16 . \\
\text { status }\end{array}$ \\
\hline 21 & $\begin{array}{l}\text { 2.4, Facility Structure, Pg 2-5, End of Bulleted } \\
\text { List: Add the following bullets: - Pool Cell } \\
\text { Monitoring Room Pool Cell Entry Airlock } \\
\text { - Supervisory Control Area }\end{array}$ & & $\begin{array}{l}\text { These have not been added to this list per } \\
L \text {. Covey. They have been added to the list } \\
\text { is section } 2.4 \text {. }\end{array}$ & C \\
\hline 22 & $\begin{array}{l}2.4 .2 .13 \text {, Hot Ce11 Water Detection and Removal, } \\
\text { Pg 2-10, para } 7 \text {, Ln 6: Change to: "...gallery panel } \\
\text { and the supervisory panel." }\end{array}$ & & $\begin{array}{l}\text { Text changed to read "...gallery panel and } \\
\text { the supervisory panel." }\end{array}$ & C \\
\hline 23 & $\begin{array}{l}\text { 2.4.6, Aqueous Makeup Area, } \mathrm{Pg} 2-12 \text {, para } 6, \operatorname{Ln} 1: \\
\text { Change to: "... and contains several no longer used } \\
\text { tanks..." }\end{array}$ & & $\begin{array}{l}\text { Text changed to read "... and contains } \\
\text { several tanks that are no longer used, and } \\
\text { a.... }\end{array}$ & C \\
\hline 24 & $\begin{array}{l}\text { 2.4.10, Pool Cel1 Area, Pg 2-14, para 2, } \operatorname{Ln} 8: \\
\text { Change to: "...Pool Cel1 } 12 \text { by transfer ports." }\end{array}$ & & $\begin{array}{l}\text { Text changed to read "...Pool Ce11 } 12 \text { by } \\
\text { transfer ports." }\end{array}$ & C \\
\hline 25 & $\begin{array}{l}\text { 2.4.10, Pool Cell Area, Pg 2-14, para 2, } \operatorname{Ln} 8: \\
\text { Change to: "...A transfer port is a ball valve which } \\
\text { can be opened and closed..." }\end{array}$ & & $\begin{array}{l}\text { Text changed to read "...A transfer port is } \\
\text { a ball valve which can be opened and } \\
\text { closed..." }\end{array}$ & C \\
\hline 26 & $\begin{array}{l}\text { 2.4.10, Pool Cell Area, Pg 2-14, para 2, Ln 11: } \\
\text { Change to: "All Pool Cells have 1 iners constructed } \\
\text { of..." }\end{array}$ & & $\begin{array}{l}\text { Text changed to read "All Pool Cells have } \\
\text { liners constructed of..." }\end{array}$ & C \\
\hline 27 & $\begin{array}{l}\text { 2.4.10, Pool Cell Area, Pg 2-14, para 2, Ln 15: } \\
\text { Change to: "..currentiy not placed on any active } \\
\text { Pool Cel1 to prevent cover block drop." }\end{array}$ & & $\begin{array}{l}\text { Text changed to read "...currently not } \\
\text { placed on active (storing capsules) pool } \\
\text { cells to prevent potential damage to the } \\
\text { capsules due to a cover block drop." }\end{array}$ & C \\
\hline 28 & $\begin{array}{l}\text { 2.4.10, Pool Cell Area, Pg 2-14, para 4, Ln 4: Drop } \\
\text { the entire last sentence that begins, "A crane } \\
\text { maintenance platform is..." }\end{array}$ & & $\begin{array}{l}\text { Text deleted "A crane maintenance platform } \\
\text { is..." }\end{array}$ & C \\
\hline 29 & $\begin{array}{l}\text { 2.4.10.1, Pool Cell Leak Detection System, Pg 2-14, } \\
\text { para 7, Ln 1: Change to: "Each Pool Cel1 has sloped } \\
\text { leak collection troughs..." }\end{array}$ & & $\begin{array}{l}\text { Text changed to read "Each pool cell has a } \\
\text { sloped leak collection system...." }\end{array}$ & C \\
\hline 30 & $\begin{array}{l}\text { 2.4.10.1, Pool Cell Leak Detection System, Pg 2-14, } \\
\text { para 7, Ln 2: Change to: "The sump system for each } \\
\text { cell is located west of each cell." }\end{array}$ & & $\begin{array}{l}\text { Text changed to read "Each system drains to } \\
\text { a collection sump located in the pipe tunnel } \\
\text { to the west of each pool cel1" }\end{array}$ & C \\
\hline
\end{tabular}

A-6400-090. \& (03/92) WEF011 


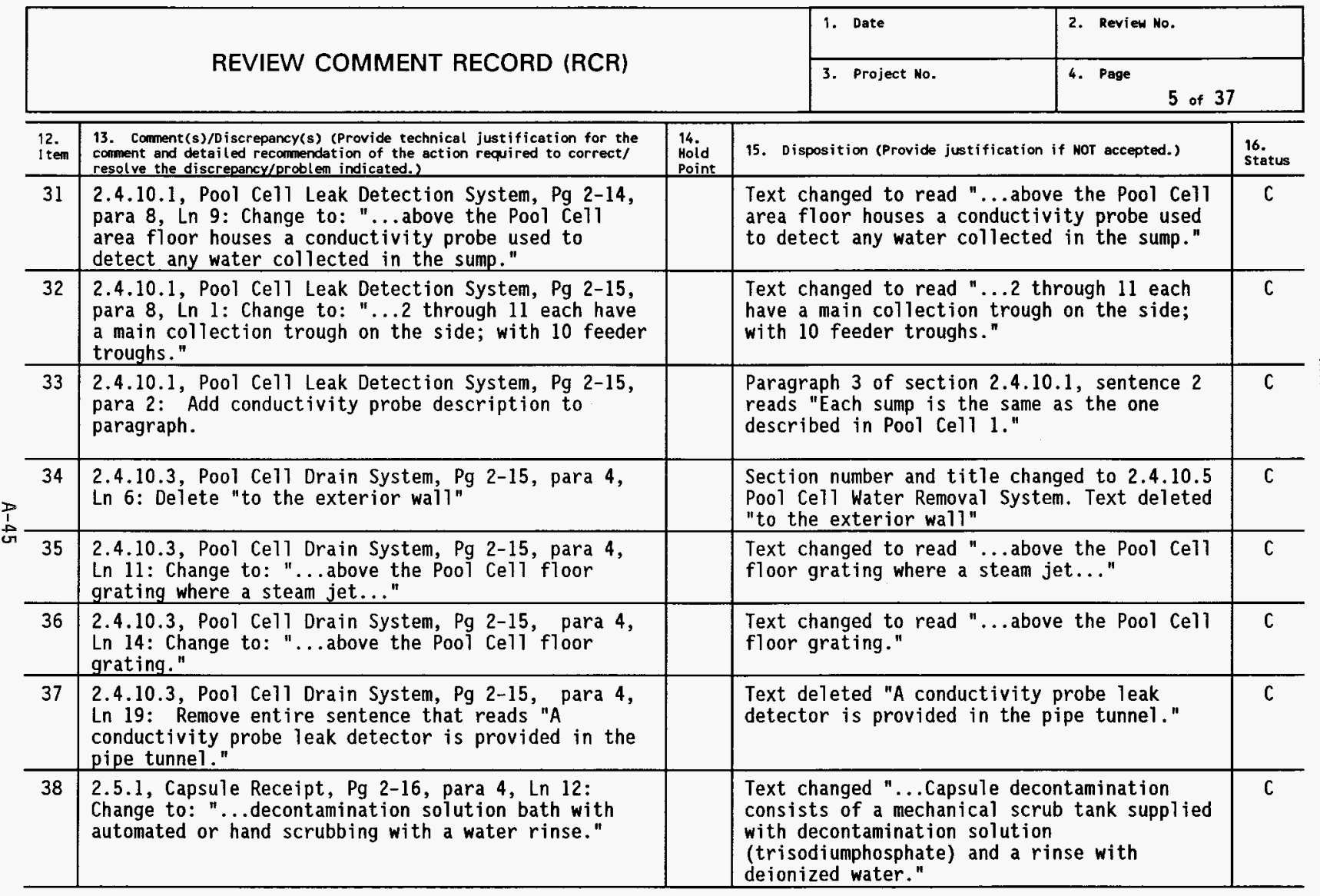

A-6400-090.1 (03/92) WEF011 


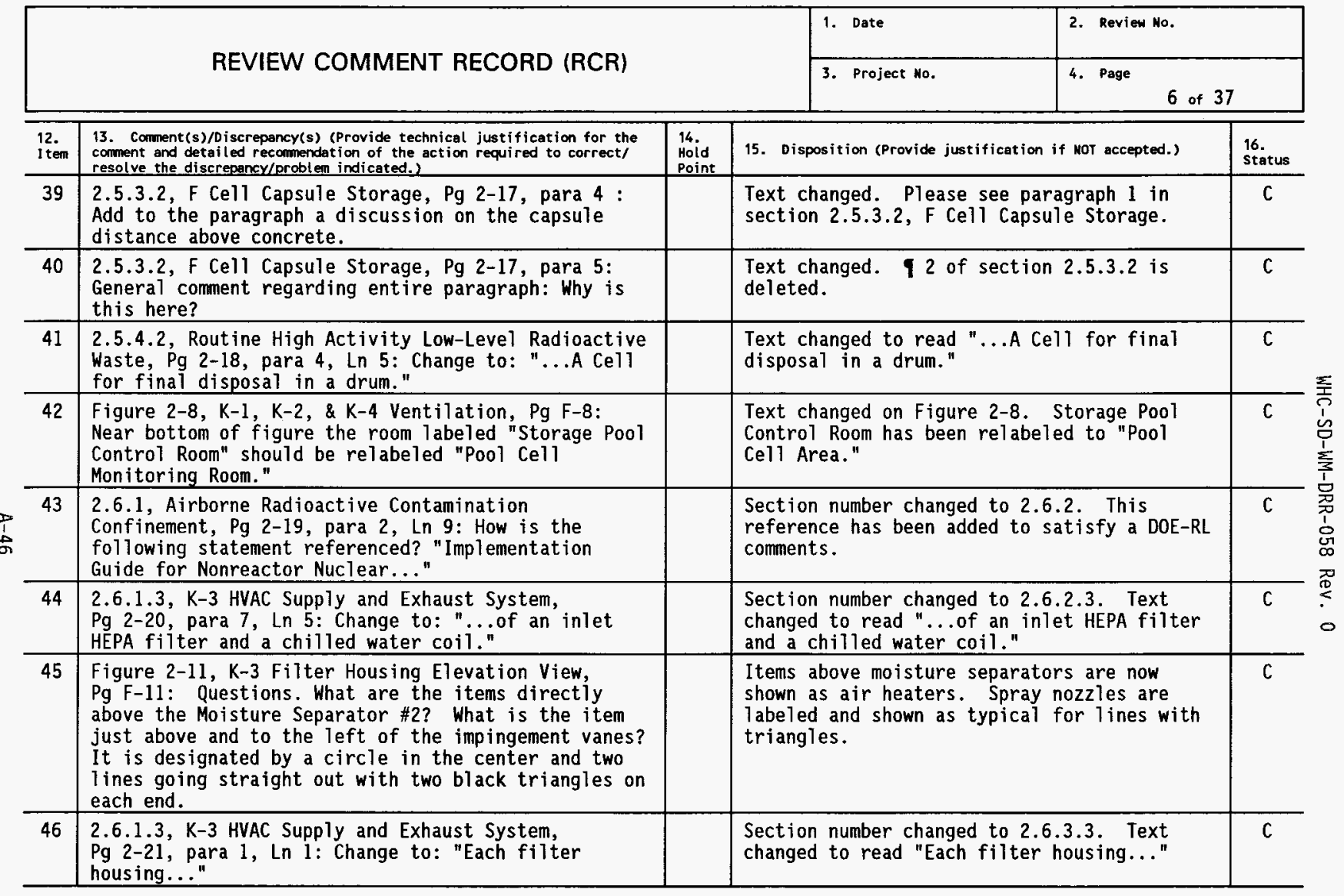




\begin{tabular}{|l|l|l|}
\hline \multirow{2}{*}{ REVIEW COMMENT RECORD (RCR) } & 1. Date & 2. Review No. \\
\cline { 2 - 3 } & 3. Project No. & 4. Page \\
\hline
\end{tabular}

\begin{tabular}{|c|c|c|c|c|}
\hline $\begin{array}{l}12 . \\
\text { Iten }\end{array}$ & $\begin{array}{l}\text { 13. Conment(s)/Discrepancy(s) (Provide technical justification for the } \\
\text { comment and detailed recommendation of the action required to correct/ } \\
\text { resolve the discrepancy/problem indicated.) }\end{array}$ & $\begin{array}{l}\text { 14. } \\
\text { Hoid } \\
\text { Point }\end{array}$ & 15. Disposition (Provide justification if NOT accepted.) & $\begin{array}{l}16 . \\
\text { Status }\end{array}$ \\
\hline 47 & $\begin{array}{l}\text { 2.6.2.3, Pool Cell Heat-Exchanger Cooling Water } \\
\text { Discharge Line, Pg 2-23, para 1, Ln 2: Change to: } \\
\text { "...discharge line is a potentially radiologically } \\
\text { contaminated effluent drain..." }\end{array}$ & & $\begin{array}{l}\text { Section number changed to } 2.6 .3 .3 \text {. Text } \\
\text { changed to read "...discharge line is a } \\
\text { potentially radiologically contaminated } \\
\text { effluent drain..." }\end{array}$ & C \\
\hline 48 & $\begin{array}{l}\text { 2.6.3, Radiation Confinement Provided by the } \\
\text { Facility Structure, Pg 2-23, para 2, Ln } 3: \text { Change } \\
\text { to: "...high-density } 3770 \mathrm{~kg} / \mathrm{m}^{3} . . . "\end{array}$ & & $\begin{array}{l}\text { Text } \text { changed to read "...high-density } 3770 \\
\mathrm{~kg} / \mathrm{m}^{3}\left(235 \mathrm{lb} / \mathrm{ft}^{3}\right) \text { reinforced concrete for } \\
\text { personnel shielding." }\end{array}$ & C \\
\hline 49 & $\begin{array}{l}2.7 .2 \text {, Fire Protection System, Pg 2-24, para } 4 \text {, } \\
\text { Ln } 4: \text { Delete entire last sentence that starts, "The } \\
\text { design of the fire protection equipment and systems } \\
\text { meets the NFPA..." }\end{array}$ & & $\begin{array}{l}\text { Text deleted "The design of the fire } \\
\text { protection equipment and systems meets the } \\
\text { NFPA... Hot Cells." }\end{array}$ & C \\
\hline 50 & $\begin{array}{l}\text { 2.7.2.1, Building Construction, Pg } 2-24 \text {, para } 5 \text {, } \\
\text { Change entire paragraph to: "The building exterior } \\
\text { and interior solid concrete walls and roof have an } \\
\text { estimated fire resistance rating of at least four } \\
\text { hours [UBC, 1991, Section } 43 \text { ] Concrete } \\
\text { construction of this type is classified as Type I } \\
\text { (443) Fire-Resistive construction in accordance with } \\
\text { NFPA } 220 \text { [1992 ed., paragraph 3-1]. However, } \\
\text { because portions of the structure consist of } \\
\text { unprotected steel (e.g., truck port) the overall } \\
\text { construction classification of the structure is Type } \\
\text { II (000), unprotected, noncombustible." }\end{array}$ & & $\begin{array}{l}\text { Text changed to read "The building exterior } \\
\text { and interior solid concrete walls and roof } \\
\text { have an estimated fire resistance rating of } \\
\text { at least } 4 \text { hours [UBC, 1991, Section 43]. } \\
\text { Concrete construction of this type is } \\
\text { classified as Type I (443) Fire-Resistive } \\
\text { construction in accordance with NFPA } 220 \\
\text { [1992 ed., paragraph } 3-1] \text {. However, because } \\
\text { portions of the structure consist of } \\
\text { unprotected steel (e.g., truck port) the } \\
\text { overall construction classification of the } \\
\text { structure is Type II (000), unprotected, } \\
\text { noncombustible." }\end{array}$ & C \\
\hline 51 & $\begin{array}{l}\text { 2.7.2.3, Fire Sprinkler Systems, Pg 2-25, Para } 4 \text {, } \\
\text { Ln 2: Change to: "...requirements contained in DOE } \\
\text { Order 5480.7A and NFPA } 13 \text { (NFPA 1991)..." }\end{array}$ & & This paragraph has been deleted. & C \\
\hline 52 & $\begin{array}{l}2.7 .2 .3 \text {, Fire Sprinkler Systems, Pg 2-25, Para } 4 \text {, } \\
\text { Ln 5: Change to: "...spacing and redundancy do } \\
\text { comply with DOE and NFPA criteria for existing } \\
\text { buildings." }\end{array}$ & & This paragraph has been deleted. & $\mathrm{C}$ \\
\hline
\end{tabular}




\begin{tabular}{|l|l|l|}
\hline \multirow{2}{*}{ REVIEW COMMENT RECORD (RCR) } & 1. Date & $2 . \quad$ Review No. \\
\cline { 2 - 3 } & 3. Project No. & 4. Page \\
\hline
\end{tabular}

\begin{tabular}{|c|c|c|c|c|}
\hline $\begin{array}{l}12 . \\
\text { I tem }\end{array}$ & $\begin{array}{l}\text { 13. Comment(s)/Discrepancy(s) (Provide technical justification for the } \\
\text { comment and detailed recommendation of the action required to correct/ } \\
\text { resolve the discrepancy/problem indicated.) }\end{array}$ & $\begin{array}{l}\text { 14. } \\
\text { Hoid } \\
\text { Point }\end{array}$ & 15. Disposition (Provide justification if NOT accepted.) & $\begin{array}{l}16 . \\
\text { Status }\end{array}$ \\
\hline 53 & $\begin{array}{l}2.7 .2 .4 \text {, Hot Cell Fire Protection Systems, Pg 2-25, } \\
\text { Para 6, Ln 5: State where in FHA this is stated, } \\
\text { "In addition, this area complies with NFPA } 101 \\
\text { (1194) criteria for a building without sprinkler } \\
\text { protection." }\end{array}$ & & $\begin{array}{l}\text { The statement is quoted from Section } 4.2 .1 \\
\text { of the Fire Hazard analysis. The reference } \\
\text { as provided is sufficient. To provide the } \\
\text { section number puts the reference in } \\
\text { jeopardy of a misnamed section due to future } \\
\text { revisions. }\end{array}$ & C \\
\hline 54 & $\begin{array}{l}\text { 2.7.2.5, Truckport Fire Protection Systems, Pg 2-26, } \\
\text { Para 1, Ln 12: Change to: "Canyon area." }\end{array}$ & & Text changed to read "Canyon area." & C \\
\hline 55 & $\begin{array}{l}\text { 2.8.1, Electrical Systems, Pg 2-27, Para 1, Ln 6: In } \\
\text { section of this sentence that starts "the load } \\
\text { transfers that occur between these two..." The two } \\
\text { is not shown on figure. }\end{array}$ & & $\begin{array}{l}\text { Moved the sentence so that it follows } \\
\text { sentences } \# 3 \text { in } 1 \text { of section } 2.8 .1 \text { which } \\
\text { ends "...... overhead } 1 \text { ine } C 8-L 7 . "\end{array}$ & C \\
\hline 56 & $\begin{array}{l}\text { 2.8.1.1, Primary Power Source, Pg 2-27, Para 2, } \\
\text { Ln 4: ". . facility via unit substation } \underline{\mathrm{C} 8-526 .} . \\
\text { Should the } \underline{\mathrm{C} 8-S 26} \text { be on the figure? }\end{array}$ & & $\begin{array}{l}\text { C8-S26 is provided on the figure near the } \\
\text { top and to the center within the dotted } \\
\text { lines. The lettering on the figure } \\
\text { indicating } C 8-526 \text { will be enlarged. }\end{array}$ & c \\
\hline 57 & $\begin{array}{l}\text { 2.8.1.2, Auxiliary Power Source, Pg } 2-27 \text {, Para } 4 \text {, } \\
\text { Ln 2: ". diesel driven generator and two } 480-V \\
\text { AC..." The } 480-V \text { AC is different on the drawing. }\end{array}$ & & $A C$ is removed from drawing and the text. & C \\
\hline 58 & $\begin{array}{l}\text { 2.8.4, Water Supply System, } \mathrm{Pg} 2-28, \text { Para } 6, \operatorname{Ln} 2: \\
\text { Change to: " } .100 \text { Area through underground export } \\
\text { water piping to the } 200 \text { East..." }\end{array}$ & & $\begin{array}{l}\text { Text changed to read "...100 Area through } \\
\text { underground export water piping to the } 200 \\
\text { East..." }\end{array}$ & C \\
\hline 59 & $\begin{array}{l}\text { 2.8.4.1, Water Supply to the } 200 \text { Areas, Pg } 2-29 \text {, } \\
\text { Para } 1 \text {, Ln } 4: \text { Change to: "... The } 182-B \text { pumphouse } \\
\text { contains five pumps each..." }\end{array}$ & & $\begin{array}{l}\text { Text changed to read "... The 182-B pumphouse } \\
\text { contains five pumps each..." }\end{array}$ & C \\
\hline 60 & $\begin{array}{l}\text { 2.8.4.1, Water Supply to the } 200 \text { Areas, Pg } 2-29 \text {, } \\
\text { Para } 2 \text {, Ln } 4: \text { Change to: "The } 182-0 \text { pumphouse } \\
\text { contains two pumps..." }\end{array}$ & & $\begin{array}{l}\text { Text changed to read "The 182-D pumphouse } \\
\text { contains two pumps..." }\end{array}$ & C \\
\hline 61 & $\begin{array}{l}\text { 2.8.4.1, Water Supply to the } 200 \text { Areas, Pg } 2-29 \text {, } \\
\text { Para } 2 \text {, Ln 6: Change to: "...water pipeline from the } \\
57,000 \mathrm{M}^{3} \text { (15 million gal) reservoir." }\end{array}$ & & $\begin{array}{l}\text { Text changed to read "...water pipeline from } \\
\text { the } 57,000 \mathrm{M}^{3} \text { ( } 15 \mathrm{mi} 11 \text { ion gal) reservoir." }\end{array}$ & C \\
\hline
\end{tabular}




\begin{tabular}{|l|l|l|}
\hline \multirow{2}{*}{ REVIEW COMMENT RECORD (RCR) } & 1. Date & 2. Review No. \\
\cline { 2 - 3 } & 3. Project No. & 4. Page \\
\hline
\end{tabular}

\begin{tabular}{|c|c|c|c|c|}
\hline $\begin{array}{l}12 . \\
1 \text { tem }\end{array}$ & $\begin{array}{l}\text { 13. Comment(s)/Discrepancy(s) (Provide technical justification for the } \\
\text { comment and detailed recommendation of the action required to correct/ } \\
\text { resolve the discrepancy/problem indicated.) }\end{array}$ & $\begin{array}{l}14 . \\
\text { Hoid } \\
\text { Point }\end{array}$ & 15. Disposition (Provide justification if NOT accepted.) & $\begin{array}{l}16 . \\
\text { status }\end{array}$ \\
\hline 62 & $\begin{array}{l}\text { 2.8.4.3.3, Raw Water System, Pg 2-30, Para } 5, \operatorname{Ln} 5: \\
\text { Change to: "...225-B enters the Low Level Waste } \\
\text { system via..." }\end{array}$ & & $\begin{array}{l}\text { The sentence is revised to read "Raw } \\
\text { water... enters the Low Level Waste System } \\
\text { through the } 61 \mathrm{~cm}(24 \text { inch }) \text { drain header." }\end{array}$ & C \\
\hline 63 & $\begin{array}{l}\text { 2.9.1, TK-100, Low-Leve1 Waste Tank/Pit, Pg } 2-31 \text {, } \\
\text { Para 2, Ln } 4: \text { Change to: "water in the sump of the K- } \\
3 \text { Filter unit." }\end{array}$ & & $\begin{array}{l}\text { The sentence is changed to " } \ldots \text { accumulated } \\
\text { liquids in the sump of the } k-3 \text { filter } \\
\text { housing and pit." }\end{array}$ & C \\
\hline 64 & $\begin{array}{l}\text { 2.9.12, TK-50, Cooling Water Tank/Pit, Pg 2-33, } \\
\text { Para 5, Ln 3: Change to: "... deionized water through } \\
\text { in-cell process tank coils..." }\end{array}$ & & $\begin{array}{l}\text { Sentence changed to "... deionized water } \\
\text { through in-cell process tank coils...." }\end{array}$ & C \\
\hline 65 & $\begin{array}{l}\text { 3.1, Introduction and Summary, Pg } 3-1 \text {, Para } 1, \ln 3: \\
\text { Question: Should the titles of the DOE Standards and } \\
\text { the WHC-CM-4-46 be included? }\end{array}$ & & $\begin{array}{l}\text { Rather than include the titles, the document } \\
\text { year was added to make the appropriate } \\
\text { reference call. }\end{array}$ & C \\
\hline 66 & $\begin{array}{l}\text { 3.1, Introduction and Summary, } \mathrm{Pg} 3-1 \text { Para } 2, \operatorname{Ln} 4: \\
\text { Change to: "The capsules were produced in WESF from } \\
1974 \text { to } 1985 \text { to reduce the quantity...." }\end{array}$ & & Change made. & C \\
\hline 67 & $\begin{array}{l}3.1 \text {, Introduction and Summary, } \mathrm{Pg} 3-1, \text { Para } 2, \operatorname{Ln} 9: \\
\text { Change to: "...private enterprises for use as } \\
\text { radiation sources..." }\end{array}$ & & Change made. & C \\
\hline 68 & $\begin{array}{l}3.3 .2 .1 \text {, Hazard Identification Results, Pg 3-9, Para } \\
1 \text {, Ln 2: Change to: "..the pool cells are } \\
\text { estimates of the radioactive material which is } \\
\text { actually..." }\end{array}$ & & Change made. & C \\
\hline 69 & $\begin{array}{l}\text { 3.3.2.1, Hazard Identification Results, Summary of } \\
\text { Hazardous Events at WESF, Pg } 3-12 \text {, Para } 1, \text { Ln } 3: \\
\text { Sentence that begins, "However, many operational } \\
\text { events and off-norma } 1 \text { occurrences..." is not a } \\
\text { complete sentence. }\end{array}$ & & Sentence fixed. & c \\
\hline 70 & $\begin{array}{l}\text { 3.3.2.1, Hazard Identification Results, Summary of } \\
\text { Hazardous Events at WESF, Pg } 3-12 \text {, Para } 2, \operatorname{Ln} 2: \\
\text { Change to: "... where cesium capsules were used as } \\
\text { radiation sources." }\end{array}$ & & Change made. & C \\
\hline
\end{tabular}




\begin{tabular}{|l|l|l|}
\hline \multirow{2}{*}{ REVIEW COMMENT RECORD (RCR) } & 1. Date & 2. Review No. \\
\cline { 2 - 3 } & 3. Project No. & 4. Page \\
\hline
\end{tabular}

\begin{tabular}{|c|c|c|c|c|}
\hline $\begin{array}{l}12 . \\
\text { Item }\end{array}$ & $\begin{array}{l}\text { 13. Comment(s)/Discrepancy(s) (Provide technical justification for the } \\
\text { comment and detailed recomnendation of the action required to correct/ } \\
\text { resolve the discrepancy/problem indicated.) }\end{array}$ & $\begin{array}{l}14 . \\
\text { Hold } \\
\text { Point }\end{array}$ & 15. Disposition (Provide justification if MOT accepted.) & $\begin{array}{l}16 . \\
\text { Status }\end{array}$ \\
\hline 71 & $\begin{array}{l}\text { 3.3.2.1, Hazard Identification Results, Summary of } \\
\text { Hazardous Events at WESF, Pg } 3-13 \text {, Bullet } 2 \text {, Ln } 4: \\
\text { Delete from sentence, "...by the manipulator to the } \\
\text { cell." }\end{array}$ & & Change made. & C \\
\hline 72 & $\begin{array}{l}\text { 3.3.2.2, Hazard Classification, } \mathrm{Pg} 3-13 \text {, Para } 4, \mathrm{Ln} \\
\text { 4: Change to: "...to complete decoupling by } \mathrm{CY} \\
\text { 1998." }\end{array}$ & & Change made. & C \\
\hline 73 & $\begin{array}{l}3.3 .2 .2 \text {, Hazard Classification, Alternate Release } \\
\text { Fractions, Pg } 3-14 \text {, Para } 7 \text {, Ln } 1: \text { Change to: "The } \\
\text { release fractions used in deriving the radioactive } \\
\text { material threshold criteria..." }\end{array}$ & & Changed to radioisotopic. & C \\
\hline 74 & $\begin{array}{l}3.3 .2 .2, \text { Hazard Classification, Alternate Release } \\
\text { Fractions, Pg 3-15, Para } 1 \text {, In } 3: \text { Change to: } \\
\text { "..the detailed analysis of Section } 3.4 .2 .7 \\
\text { provides a basis for decreasing..." }\end{array}$ & & Change made. & C \\
\hline 75 & $\begin{array}{l}\text { 3.3.2.2, Hazard Classification, Alternate Release } \\
\text { Fractions, Pg 3-15, Para 2: Define TQ in the } \\
\text { divisor of this equation. }\end{array}$ & & Definition made. & C \\
\hline 76 & $\begin{array}{l}\text { Table } 3.3 .2 .3-1, \text { HAZOP Results Summary, Pg 3-19: } \\
\text { Number } 24: \quad \mathrm{K}-3^{(5)} \text { is not referenced correctiy. }\end{array}$ & & Fixed. & C \\
\hline 77 & $\begin{array}{l}\text { 3.3.2.3.1, Planned Design and Operational Safety } \\
\text { Improvements, Pg 3-22, Para 2, Ln 1 (Title): Spe11 } \\
\text { out CLCS in title line, "Project W-252. Pool Cell } \\
\text { CLCS." }\end{array}$ & & Change made. & C \\
\hline 78 & $\begin{array}{l}\text { 3.3.2.3.1, Planned Design and Operational Safety } \\
\text { Improvements, Emergency Ion Exchange System, } \\
\text { Pg 3-23, Para 3, Ln 9: Change to: "in the Control } \\
\text { Area." }\end{array}$ & & Change made. & C \\
\hline
\end{tabular}




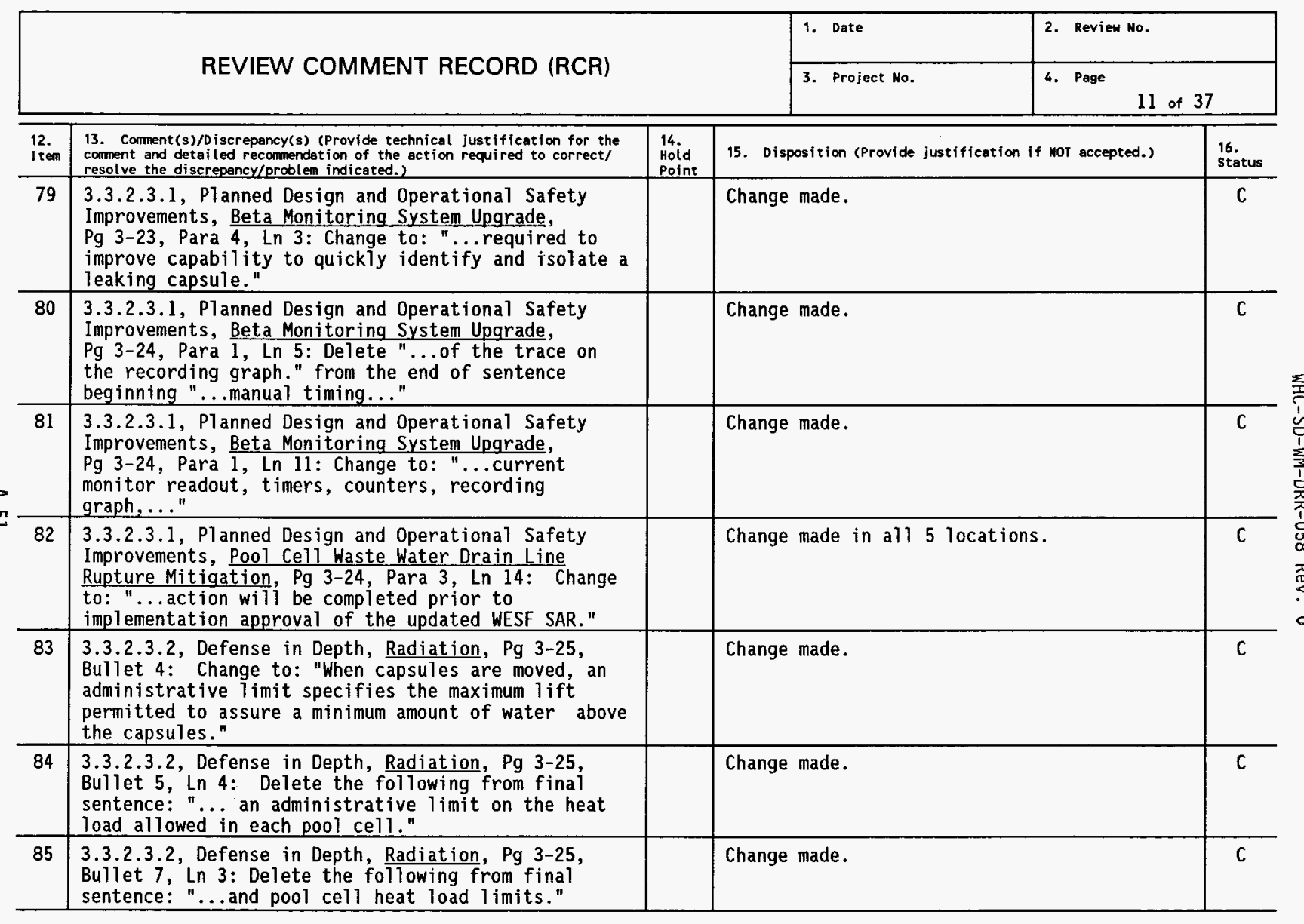




\begin{tabular}{|l|l|l|l|}
\hline \multirow{2}{*}{ REVIEW COMMENT RECORD (RCR) } & 1. Date & Review No. \\
\cline { 2 - 3 } & 3. Project No. & 4. Page \\
\hline
\end{tabular}

\begin{tabular}{|c|c|c|c|c|}
\hline $\begin{array}{l}12 . \\
\text { I tem }\end{array}$ & $\begin{array}{l}\text { 13. Corment(s)/Discrepancy(s) (Provide technical justification for the } \\
\text { corment and detailed recomnendation of the action required to correct/ } \\
\text { resolve the discrepancy/problem indicated.) }\end{array}$ & $\begin{array}{l}14 . \\
\text { Hoid } \\
\text { Point }\end{array}$ & 15. Disposition (Provide justification if NOT accepted.) & $\begin{array}{l}16 . \\
\text { Status }\end{array}$ \\
\hline 86 & $\begin{array}{l}3.3 .2 .3 .2 \text {, Defense in Depth, Radiation, Pg } 3-26 \text {, } \\
\text { Bullet } 3 \text { : Change to: "Water transfer from cel1 to } \\
\text { cell can be performed to provide a short-term water } \\
\text { supply and cooling." }\end{array}$ & & Change made. & C \\
\hline 87 & $\begin{array}{l}3.3 .2 .3 .2 \text {, Defense in Depth, Radiation, } \mathrm{Pg} 3-26, \\
\text { Para 4, Ln 2: Change to: "The recirculation } \\
\text { monitors are..." }\end{array}$ & & Change made. & C \\
\hline 88 & $\begin{array}{l}3.3 .2 .3 .2 \text {, Defense in Depth, Radiation, Pg } 3-27 \text {, } \\
\text { Para 2, Ln 9: Change to: "Also, the filters are } \\
\text { replaced if the radiation field at the filter box } \\
\text { area..." }\end{array}$ & & Change made. & C \\
\hline 89 & $\begin{array}{l}3.3 .2 .3 .2 \text {, Defense in Depth, Radiation, Pg } 3-27 \text {, } \\
\text { Para 2, In 10: Change to: "In addition, filter } \\
\text { radiation monitors would detect the presence of..." }\end{array}$ & & Change made. & $\mathrm{C}$ \\
\hline 90 & $\begin{array}{l}3.3 .2 .3 .2 \text {, Defense in Depth, Radiation, } \mathrm{Pg} 3-27 \text {, } \\
\text { Bullet } 1: \text { Question regarding "5-cm }(2-\text { in. }) " \text { Do we } \\
\text { need this detail? }\end{array}$ & & $\begin{array}{l}\text { This is used as part of the designator for } \\
\text { that line so that it is easy to tell which } \\
\text { drain line. Also, given the location of the } \\
\text { line it is unlikely that its diameter will } \\
\text { change. }\end{array}$ & C \\
\hline 91 & $\begin{array}{l}\text { 3.3.2.3.2, Defense in Depth, Radiation, } \mathrm{Pg} 3-27 \text {, } \\
\text { Para 2, Ln 2: Change to: "...cask is relied upon to } \\
\text { provide radiation shielding and additional } \\
\text { confinement for..." }\end{array}$ & & Change made. & C \\
\hline 92 & $\begin{array}{l}\text { 3.3.2.3.2, Defense in Depth, Radioactive Material, } \\
\text { Pg 3-30, Para 2, Ln 11: "The capsules themselves, } \\
\text { although suspect leakers, also act to prevent..." }\end{array}$ & & Change made. & C \\
\hline 93 & $\begin{array}{l}\text { 3.3.2.3.2, Defense in Depth, Flammable Materials, Pg } \\
3-31 \text {, Bullet } 1 \text {, Ln } 3: \text { "... solid combustibles in } A \\
\text { Ce11 must be packaged..." Is packaged defined } \\
\text { anywhere? }\end{array}$ & & $\begin{array}{l}\text { Packaging definition added to state that } \\
\text { package must preclude airflow up through } \\
\text { waste: a steel container, for example a 55- } \\
\text { gal drum or steel pail. The package does } \\
\text { not have to be closed. }\end{array}$ & C \\
\hline
\end{tabular}




\begin{tabular}{|l|l|}
\hline 1. Date & 2. Review Mo. \\
\hline 3. Project No. & 4. Page 13 of 37 \\
\hline
\end{tabular}

\begin{tabular}{|c|c|c|c|c|}
\hline $\begin{array}{l}12 . \\
\text { Item }\end{array}$ & $\begin{array}{l}\text { 13. Comment(s)/Discrepancy(s) (Provide technical justification for the } \\
\text { comment and detailed recomnendation of the action requi red to correct/ } \\
\text { resolve the discrepancy/problem indicated.) }\end{array}$ & $\begin{array}{l}14 . \\
\text { Hoid } \\
\text { Point }\end{array}$ & 15. Disposition (Provide justification if NOT accepted.) & $\begin{array}{l}\text { 16. } \\
\text { Status }\end{array}$ \\
\hline 94 & $\begin{array}{l}\text { 3.3.2.3.2, Defense in Depth, Flammable Materials, Pg } \\
3-31 \text {, Bullet } 3: \text { Why isn't this information in table } \\
3.3 .2 .3-5 \text { ? }\end{array}$ & & $\begin{array}{l}\text { Accepted. The controls for the hot cell } \\
\text { fire scenarios have been } 1 \text { isted in the } \\
\text { table. }\end{array}$ & C \\
\hline 95 & $\begin{array}{l}\text { 3.3.2.3.2, Defense in Depth, Flammable Materials, Pg } \\
3-32 \text {, Para } 1 \text {, Ln } 6: \text { Why isn't "operating procedures, } \\
\text { which require spotters" listed in table } 3.3 .2 .3 .5 \text { ? }\end{array}$ & & $\begin{array}{l}\text { Accepted. These items have been added to } \\
\text { the table. }\end{array}$ & C \\
\hline 96 & $\begin{array}{l}\text { Table 3.3.2.3-5, Summary of Defense in Depth } \\
\text { Barriers, Pg } 3-35: \text { Need a specific review to assure } \\
\text { all items in Table } 3.3 .2 .3-5 \text { are discussed in text } \\
\text { and all text items are in table. }\end{array}$ & & $\begin{array}{l}\text { Accepted. To date, } 4 \text { independent reviews } \\
\text { have been made. }\end{array}$ & C \\
\hline 97 & $\begin{array}{l}\text { Table } 3.3 .2 .3-5 \text {, Summary of Defense in Depth } \\
\text { Barriers, Pg } 3-35 \text {, Row } 8 \text {, Column } 4: \text { Question about } \\
\text { SC in column } 4 \text {. Does the pool liner meet seismic } \\
\text { criteria? }\end{array}$ & & $\begin{array}{l}\text { Since this version of the chapter, the liner } \\
\text { has been changed to a defense in depth item. }\end{array}$ & C \\
\hline 98 & $\begin{array}{l}\text { Table } 3.3 .2 .3-5 \text {, Summary of Defense in Depth } \\
\text { Barriers, Pg } 3-35 \text {, Row } 18 \text {, Column } 1: \text { Question about } \\
\text { Radiation monitoring in the pool cell area. What } \\
\text { about radiation monitors in recirculation Iines? } \\
\text { Should this be in this chart? Also the Ion Exchange } \\
\text { rad monitor for worker safety? }\end{array}$ & & Additions made. & C \\
\hline 99 & $\begin{array}{l}\text { Table } 3.3 .2 .3-5 \text {, Summary of Defense in Depth } \\
\text { Barriers, Pg } 3-36 \text {, Row } 5 \text {, Column 1: Change "K-3 } \\
\text { contamination limits" to "K-3 radiation limits" }\end{array}$ & & Change made. & C \\
\hline 100 & $\begin{array}{l}\text { Table } 3.3 .2 .3-5 \text {, Summary of Defense in Depth } \\
\text { Barriers, Pg } 3-36 \text {, Row } 22 \text {, Column 1: Change "K-3 } \\
\text { Filters" to "K-3 HEPA Filters" }\end{array}$ & & Change made in all locations. & C \\
\hline 101 & $\begin{array}{l}\text { Table } 3.3 .2 .3-5 \text {, Summary of Defense in Depth } \\
\text { Barriers, Pg 3-37, Rows } 14 \text { \& } 15: \text { Could not find } \\
\text { reference to these in the text. }\end{array}$ & & $\begin{array}{l}\text { Accepted. Normal water makeup was mentioned } \\
\text { but recirculation and drain line piping had } \\
\text { to be added. }\end{array}$ & C \\
\hline 102 & $\begin{array}{l}3.3 .2 .3 .3 \text {, Worker Safety, } \mathrm{Pg} 3-40 \text {, Para } 1, \operatorname{Ln} 1: \\
\text { Change to "Migration of the radioactive material out } \\
\text { of the K-3 exhaust duct is..." }\end{array}$ & & Change made. & C \\
\hline
\end{tabular}




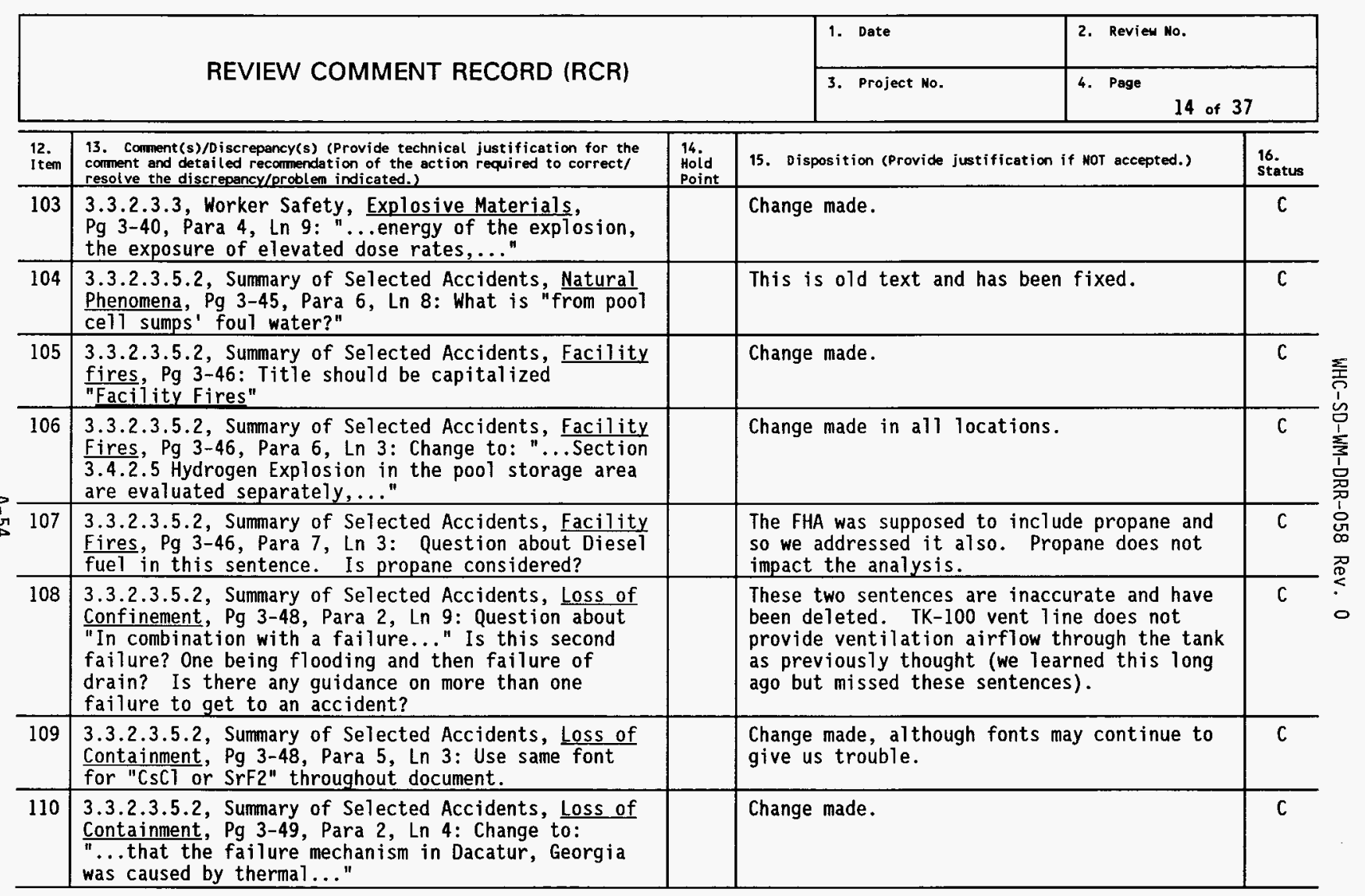




\begin{tabular}{|l|l|l|}
\hline \multirow{2}{*}{ REVIEW COMMENT RECORD (RCR) } & 1. Date & Review No. \\
\cline { 2 - 3 } & 3. Project No. & 4. Page \\
\hline
\end{tabular}

\begin{tabular}{|c|c|c|c|c|}
\hline $\begin{array}{l}12 . \\
\text { I tem }\end{array}$ & $\begin{array}{l}\text { 13. Comment(s)/Discrepancy(s) (Provide technical justification for the } \\
\text { comment and detailed recomnendation of the action required to correct/ } \\
\text { resolve the discrepancy/problem indicated.) }\end{array}$ & $\begin{array}{l}14.0 \\
\text { Hoid } \\
\text { Point }\end{array}$ & 15. Disposition (Provide justification if NOT accepted.) & $\begin{array}{l}16 . \\
\text { status }\end{array}$ \\
\hline 111 & $\begin{array}{l}\text { 3.3.2.3.5.2, Summary of Selected Accidents, Loss of } \\
\text { Containment, Pg } 3-49 \text {, Para 2, Ln 5: "...cycling } \\
\text { (i.e., thermal racheting)" Reference PNNL report } \\
\text { here. }\end{array}$ & & Change made. & C \\
\hline 112 & $\begin{array}{l}\text { 3.3.2.3.5.2, Summary of Selected Accidents, Loss of } \\
\text { Containment, Pg } 3-49 \text {, Para } 3, \text { Ln } 4: \text { Change to: } \\
\text { "...building as discussed in Section } 3.4 .2 .5 \\
\text { Hydrogen Explosions in the pool storage area." }\end{array}$ & & Change made (Pool Cell Area...) & C \\
\hline 113 & $\begin{array}{l}3.3 .2 .3 .5 .2 \text {, Summary of Selected Accidents, Loss of } \\
\text { Containment, Pg } 3-49 \text {, Para } 3 \text {, In } 8: \text { Quest ion about } \\
\text { "contaminated water leakage." Where would the } \\
\text { leaking water go? }\end{array}$ & & $\begin{array}{l}\text { Discussion expanded to indicate that water } \\
\text { would drain into pool cell sump system. }\end{array}$ & C \\
\hline 114 & $\begin{array}{l}\text { 3.3.2.3.5.2, Summary of Selected Accidents, Loss of } \\
\text { Containment, Pg } 3-49 \text {, Para } 5 \text {, Ln } 1: \text { Change to "A } \\
\text { leak from the pool cel1 waste water sump due to a } \\
\text { break in the pipe between..." }\end{array}$ & & $\begin{array}{l}\text { Wording changed, but sump is not called } \\
\text { "waste water sump". }\end{array}$ & C \\
\hline 115 & $\begin{array}{l}\text { 3.3.2.3.5.2, Summary of Selected Accidents, Loss of } \\
\text { Containment, Pg } 3-49 \text {, Para 5, Ln 2: Change to: "The } \\
\text { waste water collection sump drains from..." }\end{array}$ & & See above response. & C \\
\hline 116 & $\begin{array}{l}3.3 .2 .3 .5 .2 \text {, Summary of Selected Accidents, Loss of } \\
\text { Pool Cell Water, Pg 3-50, Para 2, Ln 8: Change to: } \\
\text { "Phenomena, 3.4.2.2 External Events, Section } 3.4 .2 .5 \\
\text { Hydrogen Explosions in the pool storage area, and } \\
\text { Section } 3.4 .3 . \ldots .\end{array}$ & & Change made. & C \\
\hline 117 & $\begin{array}{l}\text { 3.4.1.2, Source Term Modeling Methodology, Pg } 3-51 \text {, } \\
\text { Para 6, Ln 4: Put AED in the List of Terms. }\end{array}$ & & Accepted. & C \\
\hline 118 & $\begin{array}{l}\text { 3.4.1.3, Consequence Analysis Methodology, Pg } 3-52 \text {, } \\
\text { Para } 5, \text { Ln 12: Question about WHC (1996). The plume } \\
\text { meander... How can it be determined which reference } \\
\text { this is? }\end{array}$ & & Appropriate reference made. & $\mathrm{C}$ \\
\hline
\end{tabular}




\section{REVIEW COMMENT RECORD (RCR)}

\begin{tabular}{|l|l|}
\hline 1. Date & 2. Review No. \\
\hline 3. Project No. & 4. Page 16 of 37 \\
\hline
\end{tabular}

\begin{tabular}{|c|c|c|c|c|}
\hline Item & $\begin{array}{l}\text { 13. Comment(s)/Discrepancy(s) (Provide technical justification for the } \\
\text { comment and detailed recommendation of the action required to correct/ } \\
\text { resolve the discrepancy/problem indicated.) }\end{array}$ & $\begin{array}{l}14 . \\
\text { Hoid } \\
\text { Point }\end{array}$ & 15. Disposition (Provide justification if NOT accepted.) & $\begin{array}{l}16 . \\
\text { status }\end{array}$ \\
\hline 119 & $\begin{array}{l}3.4 .1 .3 \text {, Consequence Analys is Methodology, } \mathrm{Pg} 3-52 \text {, } \\
\text { Para } 5 \text {, Ln } 14: \text { Question/statement about the final } \\
\text { part of the last sentence, "the more significant } \\
\text { correction is used." Meander and Wake are not used } \\
\text { simultaneously? "...the more significant correction } \\
\text { is used." is confusing. }\end{array}$ & & Sentence removed. & C \\
\hline 120 & $\begin{array}{l}\text { 3.4.1.3, Consequence Analysis Methodology, Pg 3-53, } \\
\text { Para } 1 \text {, Ln } 1 \text { : Change to: "For offsite calculations, } \\
\text { the Hanford Site Boundary (i.e., Columbia River)..." }\end{array}$ & & Change made. & C \\
\hline 121 & $\begin{array}{l}\text { 3.4.1.3, Consequence Analysis Methodology, Pg 3-54, } \\
\text { Para } 1 \text {, Ln } 1: \text { Boundary stated in this first } \\
\text { sentence is incorrect. }\end{array}$ & & Corrected. & C \\
\hline 122 & $\begin{array}{l}3.4 .1 .3 \text {, Consequence Analys is Methodology, Pg 3-56, } \\
\text { Para } 1 \text {, Ln } 3: \text { Question about "The plume submersion } \\
\text { dose..." What does this mean? }\end{array}$ & & Elaboration added to text. & $\mathrm{C}$ \\
\hline 123 & $\begin{array}{l}\text { 3.4.1.4, Application of Evaluation Guidelines, } \\
\text { Pg 3-56, Para 2, Ln 2: Question about "WHC (1996)." } \\
\text { How determine which reference? }\end{array}$ & & Appropriate reference made. & C \\
\hline 124 & $\begin{array}{l}\text { 3.4.1.4, Application of Evaluation Guidelines, } \\
\text { Pg 3-56, Para 4, Ln 2: Question about "WHC (1996)." } \\
\text { How determine which reference? }\end{array}$ & & Appropriate reference made. & C \\
\hline 125 & $\begin{array}{l}\text { 3.4.2.1.1, Survey Results, Pg } 3-59 \text {, Para } 4 \text {, Under } \\
\text { Structures: K-1-1 Filter building has been omitted. }\end{array}$ & & Added. & C \\
\hline 126 & $\begin{array}{l}3.4 .2 .1 .1 \text {, Survey Results, Pg } 3-59 \text {, Para } 4 \text {, Under } \\
\text { Systems: (1) Bridge Cranes and Support Systems and } \\
\text { (2) Pool Cell Powered Catwalk has been omitted. }\end{array}$ & & Added. & C \\
\hline 127 & $\begin{array}{l}\text { 3.4.2.1.1, Survey Results, } \mathrm{Pg} 3-60 \text {, Number } 1, \operatorname{Ln} 5: \\
\text { Change Rev. } 11 \text { to Rev. } 12 \text {, and (DOE-RL 1989) is } \\
\text { different than the Natural Phenomena Hazards Survey. }\end{array}$ & & $\begin{array}{l}\text { Accepted. Rev. changed. The way the } \\
\text { sentence is structured, two references are } \\
\text { necessary, the first for the NPHS and the } \\
\text { second for SDC } 4.1 \text {. }\end{array}$ & C \\
\hline
\end{tabular}




\begin{tabular}{|l|l|l|}
\hline \multirow{2}{*}{ REVIEW COMMENT RECORD (RCR) } & 1. Date & 2. Review Mo. \\
\cline { 2 - 3 } & 3. Project No. & 4. Page \\
\end{tabular}

\begin{tabular}{|c|c|c|c|c|}
\hline $\begin{array}{l}12 . \\
\text { I tem }\end{array}$ & $\begin{array}{l}\text { 13. Comment(s)/Discrepancy(s) (Provide technical justification for the } \\
\text { comment and detailed recommendation of the action required to correct/ } \\
\text { resolve the discrepancy/problem indicated.) }\end{array}$ & $\begin{array}{l}14 . \\
\text { Hoid } \\
\text { Point }\end{array}$ & 15. Disposition (Provide justification if NOt accepted.) & $\begin{array}{l}16 . \\
\text { Status }\end{array}$ \\
\hline 128 & $\begin{array}{l}\text { 3.4.2.1.2, Design Basis Earthquake, } \mathrm{Pg} 3-61 \text {, Para } 3 \text {, } \\
\text { Ln 5: Change "WESF Earthquake Analysis" to } \\
\text { "Earthquake Analysis of the Waste Encapsulation } \\
\text { Storage Facility" }\end{array}$ & & Change made. & C \\
\hline 129 & $\begin{array}{l}3.4 .2 .1 .2 .1 \text {, Scenario Development, Pg 3-62, Under } \\
\text { first section of bullets, add • Alternating Current } \\
\text { Power Backup and - Pool Cell Instrumentation and } \\
\text { HVAC Area }\end{array}$ & & $\begin{array}{l}\text { NPHS says that if these were to be evaluated } \\
\text { it is highly likely that they would be shown } \\
\text { to survive the DBE loads, however, the fact } \\
\text { remains that no such evaluation was } \\
\text { performed and they were not designed to } \\
\text { resist DBE loads and are therefore assumed } \\
\text { to fail. }\end{array}$ & C \\
\hline 130 & $\begin{array}{l}3.4 .2 .1 .2 .1 \text {, Scenario Development, } \mathrm{Pg} 3-62 \text {, Second } \\
\text { section of bullets, Bullet } \mathrm{l} \text { and Bullet } 3 \text { are } \\
\text { incorrect per G. Wagenblast and definition in above } \\
\text { paragraph. }\end{array}$ & & Same as 129 & C \\
\hline 131 & $\begin{array}{l}\text { 3.4.2.1.2.1, Scenario Development, } \mathrm{Pg} 3-63 \text {, Para } 1 \text {, } \\
\text { Ln 2: Statement " ...diesel generator is not } \\
\text { designed for DBE loads, electric power is" is } \\
\text { inconsistent with G. Wagenblast, 1994. }\end{array}$ & & Same as 129 . & C \\
\hline 132 & $\begin{array}{l}3.4 .2 .1 .2 .1 \text {, Scenario Development, } \mathrm{Pg} 3-64 \text {, Para } 2 \text {, } \\
\text { Ln } 7 \text { : Need to clarify what you are trying to say, } \\
\text { "... with a subsequent of the inlet and..." }\end{array}$ & & Text deleted. & C \\
\hline 133 & $\begin{array}{l}\text { 3.4.2.1.2.1, Scenario Development, Pg 3-64, Para } 3 \text {, } \\
\text { Ln 5: Basis for the numbers in } 5 \text { days and } 18 \text { days } \\
\text { should be referenced or calculated here. }\end{array}$ & & $\begin{array}{l}\text { Will provide this basis in Hey (1996). } \\
\text { Reference added. }\end{array}$ & C \\
\hline 134 & $\begin{array}{l}\text { 3.4.2.1.2.2, Source Term Analysis, Pg } 3-65 \text {, Para } 3 \text {, } \\
\text { Ln 4: "Table 3.4.1-1 says .1 and text says } 1.0 \text { from } \\
\text { Mishima (1994),..." Please make consistent. }\end{array}$ & & Change made. & $\mathrm{C}$ \\
\hline 135 & $\begin{array}{l}\text { 3.4.2.1.2.2, Source Term Analysis, Pg } 3-65 \text {, Para } 3 \text {, } \\
\text { Ln 9: Change to: " } \ldots \text { and } \mathrm{K}-3 \text { exhaust duct } \\
\text { contamination, which has been flooded previously." }\end{array}$ & & Change made. & C \\
\hline
\end{tabular}




\begin{tabular}{|l|l|}
\hline 1. Date & 2. Review No. \\
\hline 3. Project ko. & 4. Page 18 of 37 \\
\hline
\end{tabular}

\begin{tabular}{|c|c|c|c|c|}
\hline $\begin{array}{l}12 . \\
\text { item }\end{array}$ & $\begin{array}{l}\text { 13. Corment(s)/Discrepancy(s) (Provide technical justification for the } \\
\text { comment and detailed recommendation of the action required to correct/ } \\
\text { resolve the discrepancy/problem indicated.) }\end{array}$ & $\begin{array}{l}14 . \\
\text { Hold } \\
\text { Point }\end{array}$ & 15. Disposition (Provide justification if wOT accepted.) & $\begin{array}{l}16 . \\
\text { Status }\end{array}$ \\
\hline 136 & $\begin{array}{l}3.4 .2 .1 .2 .2 \text {, Source Term Analysis, Pg 3-65: General } \\
\text { Comment: Is it ever stated that for inhalation } \\
\text { accidents, strontium is conservatively used because } \\
\text { of greater inhalation unit dose and for water } \\
\text { accidents cesium is conservatively used because of } \\
\text { its greater solubility? }\end{array}$ & & $\begin{array}{l}\text { Yes, this is mentioned in individual } \\
\text { analyses as appropriate. }\end{array}$ & C \\
\hline 137 & $\begin{array}{l}\text { 3.4.2.1.2.5, Summary of Safety SSCs and IOSR } \\
\text { Controls, Pg } 3-67 \text {, Para } 1 \text {, Ln } 1 \text { : Confirm that } \\
3.4 .3 .1 \text { in this sentence is correct reference. }\end{array}$ & & $\begin{array}{l}\text { Correct reference is } 3.4 .3 .2 \text {, BDBE. A11 } \\
\text { occurrences for this type of reference have } \\
\text { been corrected. }\end{array}$ & C \\
\hline 138 & $\begin{array}{l}\text { 3.4.2.1.2.5, Summary of Safety SSCs and IOSR } \\
\text { Controls, Pg 3-67, Bullet 4, Ln 3: Confirm that } \\
\text { following statement is correct, "(see Section } \\
\text { 3.4.2.1)." }\end{array}$ & & Confirmed. & C \\
\hline 139 & $\begin{array}{l}\text { 3.4.2.1.2.5, Summary of Safety SSCS and IOSR } \\
\text { Controls, Pg 3-68, Para 1, Ln 9: "This action wi1l } \\
\text { be completed prior to WESF SAR Implementation } \\
\text { approval." }\end{array}$ & & Change made. & C \\
\hline 140 & $\begin{array}{l}\text { 3.4.2.2.1.5, Summary of Safety SSCs and IOSR } \\
\text { Contro1s, Pg } 3-70 \text {, Para } 6 \text {, Ln } 2: \text { Check to assure if } \\
3.4 .2 .5 .3 \text { is correct reference. }\end{array}$ & & $\begin{array}{l}\text { Correct reference is } 3 \cdot 4 \cdot 2 \cdot 5.5 \text {. Change } \\
\text { made. }\end{array}$ & C \\
\hline 141 & $\begin{array}{l}\text { 3.4.2.2.2.1, Adjacent Facility Release from Seismic } \\
\text { Event, Pg 3-71, Para 3, Ln 5: "WHC (1996)" needs to } \\
\text { be clear as to which reference this is. }\end{array}$ & & $\begin{array}{l}\text { WHC, } 1996 \mathrm{~b} \text { is correct reference (B Plant } \\
\text { ISB) }\end{array}$ & $\mathrm{C}$ \\
\hline 142 & $\begin{array}{l}\text { 3.4.2.2.2.1, Adjacent Facility Release from Seismic } \\
\text { Event, Pg 3-71, Para 4, Ln 5: Regarding the } \\
\text { statement that WESF will not longer be dependent } \\
\text { upon B Plant for demineralized water. NOTE: the new } \\
\text { demineralized water system is going along the } \\
\text { B Plant/WESF wall. }\end{array}$ & & $\begin{array}{l}\text { Understood. No credit is given for the } \\
\text { survival of normal water makeup so this does } \\
\text { not change the analysis. }\end{array}$ & C \\
\hline
\end{tabular}




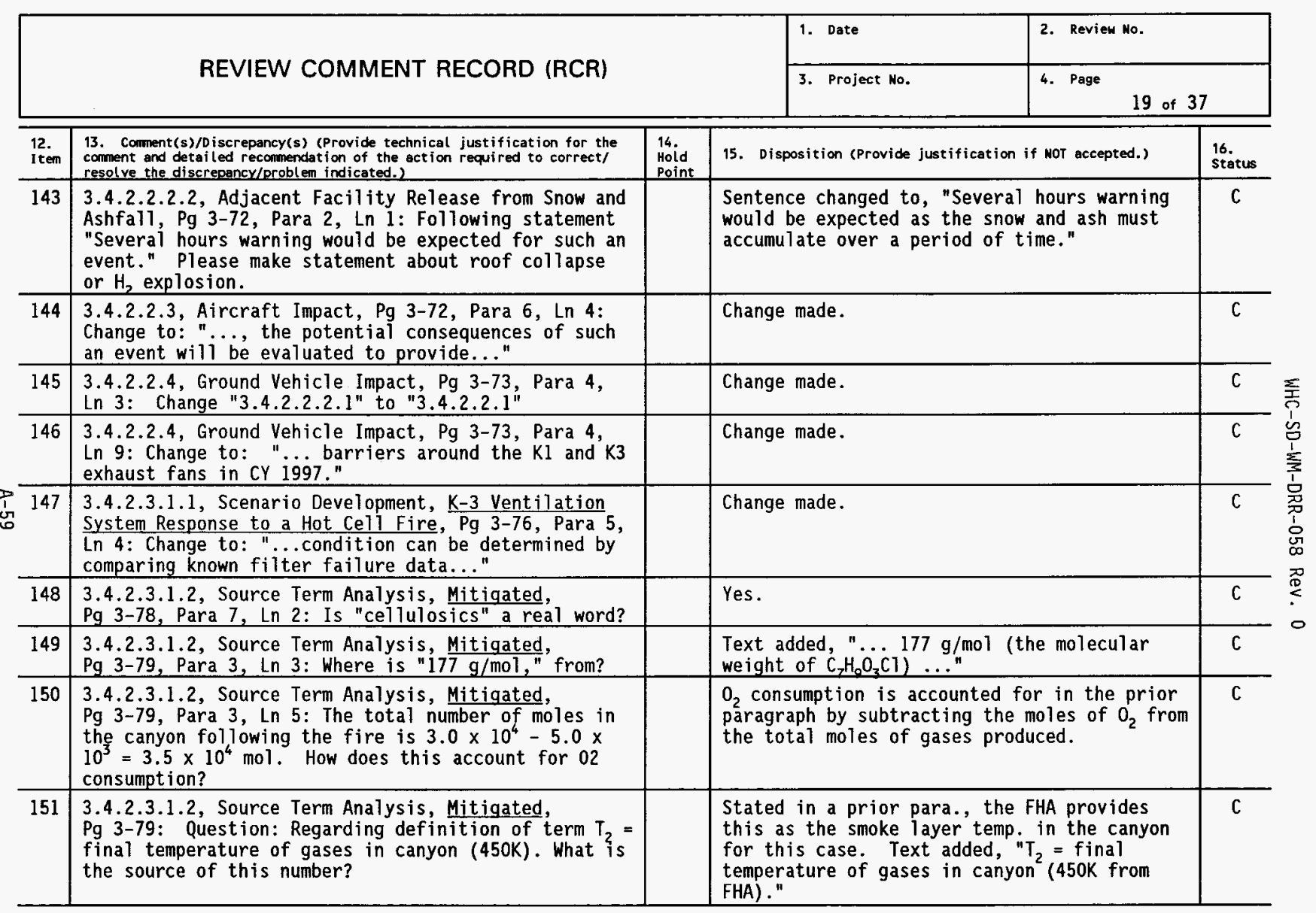




\begin{tabular}{|l|l|}
\hline 1. Date & 2. Review No. \\
\hline 3. Project No. & 4. Page 20 of 37 \\
\hline
\end{tabular}

\begin{tabular}{|c|c|c|c|c|}
\hline $\begin{array}{l}\text { 12. } \\
\text { Item }\end{array}$ & $\begin{array}{l}\text { 13. Comment(s)/Discrepancy(s) (Provide technical justification for the } \\
\text { comment and detailed recommendation of the action required to correct/ } \\
\text { resolve the discrepancy/problem indicated.) }\end{array}$ & $\begin{array}{l}\text { 14. } \\
\text { Hold } \\
\text { Point }\end{array}$ & 15. Disposition (Provide justification if NOT accepted.) & $\begin{array}{l}16 . \\
\text { status }\end{array}$ \\
\hline 152 & 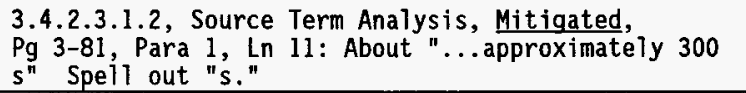 & & Change made. & C \\
\hline 153 & $\begin{array}{l}\text { 3.4.2.3.1.2, Source Term Analysis, Mitigated, } \\
\text { Pg 3-82, Equation near bottom of page. Question. } \\
\text { Where are all these calculation documented and } \\
\text { checked? Second equation group, top line of } \\
\text { equation, "(673K)" Question. Why is this different } \\
\text { from A cel1 and where is it documented? }\end{array}$ & & $\begin{array}{l}\text { 1) } 2 \text { eqns. are the ideal gas law. The other } \\
\text { eqn. is basic text book thermodynamics. } \\
\text { 2) the } 673 \mathrm{~K} \text { is the smoke layer temp. in the } \\
\text { hot cel1 while the } 450 \mathrm{~K} \text { is the smoke layer } \\
\text { temp. in the canyon. In any event, the } \mathrm{A} \\
\text { Cel1 and B-E Cell fire models are based on } \\
\text { different cases analyzed in the FHA and } \\
\text { therefore, have different fire } \\
\text { characteristics. }\end{array}$ & C \\
\hline 154 & $\begin{array}{l}\text { 3.4.2.3.1.3, Consequence Analysis, A Cell, } \\
\text { Unmitigated Condition, Pg } 3-84 \text {, Para } 3 \text {, Ln } 1: \\
\text { Reference } 3.4 .1 .2 \text { is wrong reference. Should be } \\
\text { 3.4.1.3. }\end{array}$ & & Change made for all occurrences. & C \\
\hline 155 & $\begin{array}{l}\text { 3.4.2.3.1.3, Consequence Analysis, } \frac{A C e l l}{\text { Check reference }} \\
\text { Condition, Pg } 3-84, \text { Para } 4, \operatorname{Ln} 1: \\
3.4 .1 \text { to make sure it is correct. }\end{array}$ & & $\begin{array}{l}\text { Correct reference is to } 3.4 .1 .3 \text {. All } \\
\text { occurrences changed. }\end{array}$ & C \\
\hline 156 & $\begin{array}{l}\text { 3.4.2.3.1.3, Consequence Analysis, A Cell, } \frac{\text { Mitigated }}{3.4 .1 .2} \\
\text { Condition, Pg 3-85, Para 1, Ln 1: Reference } \\
\text { should b 3.4.13. }\end{array}$ & & See 154 . & C \\
\hline 157 & $\begin{array}{l}3.4 .2 .3 .1 .3 \text {, Consequence Analysis, } \mathrm{B} / \mathrm{C} \text { and } \mathrm{D} / \mathrm{E} \\
\text { Cel1s, Unmitigated Condition, } \mathrm{Pg} 3-85 \text {, Para } 2 \text {, Ln } 1: \\
\text { Please check Reference } 3.4 .1 \text { to make sure it is } \\
\text { correct. }\end{array}$ & & See 155 . & C \\
\hline 158 & $\begin{array}{l}\text { 3.4.2.3.1.3, Consequence Analysis, Mitigated } \\
\text { Condition, Pg 3-85, Para 4, Ln } 1 \text { : Please check } \\
\text { Reference 3.4.1 to make sure it is correct. }\end{array}$ & & See 155 & C \\
\hline
\end{tabular}




\begin{tabular}{|l|l|l|l|}
\hline \multirow{2}{*}{ REVIEW COMMENT RECORD (RCR) } & 1. Date & Review Mo. \\
\cline { 2 - 3 } & 3. Project Mo. & 4. Page 21 of 37 \\
\hline
\end{tabular}

\begin{tabular}{|c|c|c|c|c|}
\hline $\begin{array}{l}12 . \\
\text { Item }\end{array}$ & $\begin{array}{l}\text { 13. Comment(s)/Discrepancy(s) (Provide technical justification for the } \\
\text { corment and detailed recommendation of the action required to correct/ } \\
\text { resolve the discrepancy/problem indicated.) }\end{array}$ & $\begin{array}{l}14 . \\
\text { Hoid } \\
\text { Point }\end{array}$ & 15. Disposition (Provide justification if NOT accepted.) & $\begin{array}{l}16 . \\
\text { Status }\end{array}$ \\
\hline 159 & $\begin{array}{l}3.4 .2 .3 .1 .4 \text {, Comparison to Guidel ines, } \mathrm{B} / \mathrm{C} \text { and } \mathrm{D} / \mathrm{E} \\
\text { Cells, Pg } 3-86 \text {, Para } 4 \text {, Ln } 12: \text { Change to: "..this } \\
\text { paint has been removed over the years by acid } \\
\text { washing." }\end{array}$ & & Change made. & C \\
\hline 160 & $\begin{array}{l}\text { 3.4.2.3.1.5, Summary of Safety SSCs and IOSR } \\
\text { Controls, Future Commitments, Pg 3-87, Para 2, Ln 5: } \\
\text { "SAR Implementation." }\end{array}$ & & Change made. & C \\
\hline 161 & $\begin{array}{l}\text { 3.4.2.3.2.1, Scenario Development, } \mathrm{Pg} 3-88 \text {, Para } 5 \text {, } \\
\text { Ln 6: Change "four possible operating configurations } \\
\text { to "three possible operating configurations." }\end{array}$ & & $\begin{array}{l}\text { There are four cases analyzed in the FHA. } \\
\text { The case with the roll-up door closed and } \\
\text { the coverblocks in-place was inadvertently } \\
\text { left out of the ISB. It is now added. }\end{array}$ & C \\
\hline 162 & $\begin{array}{l}3.4 .2 .3 .2 .1 \text {, Scenario Development, } \mathrm{Pg} 3-89 \text {, Bullet } \\
4 \text {, Ln 2: The statement "any smoke which is drawn } \\
\text { into the K-1 exhaust system either before or after } \\
\text { the door was opened would cause the K-1 HEPA filters } \\
\text { to plug" seems very conservative and unnecessary. }\end{array}$ & & $\begin{array}{l}\text { During preparation of the analysis, another } \\
\text { reviewer specifically indicated that we } \\
\text { should address impacts to the K-1 system. } \\
\text { The rest of the subject paragraph explains } \\
\text { that smoke loading of the K-l filters plays } \\
\text { no role in the analysis because of the open rol } \\
\text { up door. }\end{array}$ & c \\
\hline 163 & $\begin{array}{l}3.4 .2 .3 .2 .1 \text {, Scenario Development, Pg } 3-90 \text {, Para } 3 \text {, } \\
\text { Question regarding entire paragraph: Is there any } \\
\text { reduction in particulate possible because of the } \\
\text { water being placed by sprinklers? }\end{array}$ & & $\begin{array}{l}\text { Activation of the sprinklers could reduce } \\
\text { the release in the mitigated case, However, } \\
\text { this would be difficult to take credit for } \\
\text { and is not needed because of the minimal } \\
\text { doses in the mitigated case. }\end{array}$ & C \\
\hline 164 & $\begin{array}{l}\text { 3.4.2.3.2.2, Source Term Analysis, Pg 3-90, Para 6, } \\
\text { Lines } 6 \text { \& 13: Brehm (1996) is the wrong reference. }\end{array}$ & & $\begin{array}{l}\text { Reference removed. Text modified to } \\
\text { indicate the } 30 \text { bags o } 50 \mathrm{mR} / \mathrm{hr} \text { is assumed } \\
\text { as a starting point for the analysis. }\end{array}$ & C \\
\hline 165 & $\begin{array}{l}3.4 .2 .3 .2 .3 \text {, Consequence Analysis, Unmitigated } \\
\text { Condition, Pg } 3-92 \text {, Para } 6, \operatorname{Ln} 1: \text { Confirm Reference } \\
3.4 .1 \text { in first sentence. }\end{array}$ & & See 155 & C \\
\hline 166 & $\begin{array}{l}\text { 3.4.2.3.2.3, Consequence Analysis, Mitigated } \\
\text { Condition, Pg 3-93, Para } 3, \operatorname{Ln} 1: \text { Reference } 3.4 .1 .2 \\
\text { in first sentence should be } 3.4 .13 \text {. }\end{array}$ & & See 154 & C \\
\hline
\end{tabular}




\begin{tabular}{|l|l|}
\hline 1. Date & 2. Review No. \\
\hline 3. Project No. & 4. Page 22 of 37 \\
\hline
\end{tabular}

\begin{tabular}{|c|c|c|c|c|}
\hline $\begin{array}{l}12 . \\
\text { It tem }\end{array}$ & $\begin{array}{l}\text { 13. Comment(s)/Discrepancy(s) (Provide technical justification for the } \\
\text { comment and detailed recommendation of the action required to correct/ } \\
\text { resolve the discrepancy/problem indicated,) }\end{array}$ & $\begin{array}{l}14 . \\
\text { Hoid } \\
\text { Point }\end{array}$ & 15. Disposition (Provide justification if mot accepted.) & $\begin{array}{l}\text { 16. } \\
\text { Status }\end{array}$ \\
\hline 167 & $\begin{array}{l}3.4 .2 .4 \text {, Loss of Confinement, } \mathrm{Pg} 3-94 \text {, Para } 3 \text {, } \\
\text { Entire Paragraph: What is the purpose of this } \\
\text { paragraph? }\end{array}$ & & $\begin{array}{l}\text { This paragraph is left over from a change in } \\
\text { organization of the analysis. It is } \\
\text { removed. }\end{array}$ & C \\
\hline 168 & $\begin{array}{l}\text { 3.4.2.4.1.2, Source Term Analysis, Pg 3-96, Para } 7 \text {, } \\
\text { Ln 3: Change to: "...as an upper bound considering } \\
\text { time to detect the high flow condition..." }\end{array}$ & & Change made. & C \\
\hline 169 & $\begin{array}{l}\text { 3.4.2.4.1.2, Source Term Analysis, Mitigated } \\
\text { Condition, Pg 3-97, Para 3, Ln 2: How did you } \\
\text { determine "1.0 } 1.010^{-3} ?\end{array}$ & & $\begin{array}{l}1 \text { - } 03 \text { was taken for } 99.9 \% \text { overall efficiency } \\
\text { - low enough to reduce consequences below } \\
\text { EGs, but large enough to leave the plant } \\
\text { room to operate. }\end{array}$ & C \\
\hline 170 & $\begin{array}{l}3.4 .2 .4 .1 .2 \text {, Source Term Analysis, Mitigated } \\
\text { Condition, Pg 3-97, Bullet } 6 \text {, Ln } 2: \frac{\text { Change to: }}{\text { "...duration is chosen as an upper bound considering }} \\
\text { time..." }\end{array}$ & & Change made. & C \\
\hline 171 & $\begin{array}{l}\text { 3.4.2.4.1.4, Comparison to Guidelines, Unmitigated } \\
\text { Condition, Pg 3-98, Para 3, Ln 1: Change 414 to } 390 .\end{array}$ & & Change made. & C \\
\hline 172 & $\begin{array}{l}3.4 .2 .4 .1 .5 \text {, Summary of Safety-Class and Safety- } \\
\text { Significant SSCs and IOSR Controls, Pg } 3-99 \text {, Bullet } \\
3: \text { Need to add a radiation number in addition to } \\
\text { curie values to this statement. }\end{array}$ & & $\begin{array}{l}\text { The accident analysis establishes the } \\
\text { inventory limit, but does not specify how } \\
\text { the plant will control it. i.e., the dose } \\
\text { rate is how the plant implements the } \\
\text { inventory limit (not germane to the accident } \\
\text { analysis). }\end{array}$ & C \\
\hline 173 & $\begin{array}{l}3.4 .2 .4 .2 \text {, Loss of } \mathrm{K}-3 \text { Ventilation } \mathrm{Flow} \text {, Storage of } \\
\text { Capsules in } \mathrm{F}-\mathrm{Cell} \text {, Pg } 3-101 \text {, Para } 3 \text {, Ln } 2 \text { : Replace } \\
\text { "The intent is to find the maximum number of } \\
\text { capsules that can be stored in the } \mathrm{F} \text { Cell without } \\
\text { exceeding a set of thermal limits" with "The intent } \\
\text { is to determine if the predesignated capsule spacing } \\
\text { can be used to store capsules in } \mathrm{F} \text { cell without } \\
\text { exceeding a set of thermal limits." }\end{array}$ & & Change made. & C \\
\hline
\end{tabular}




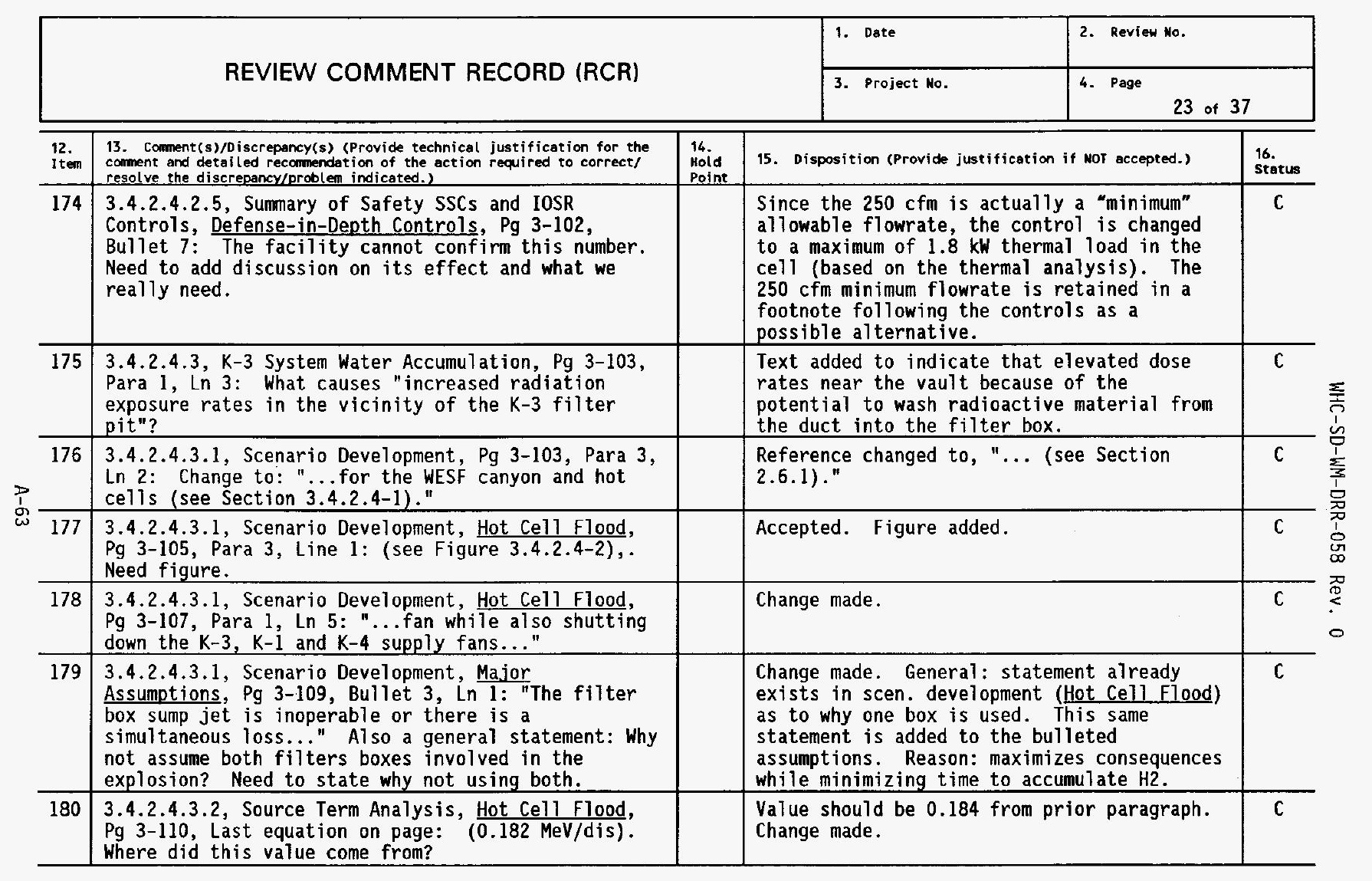




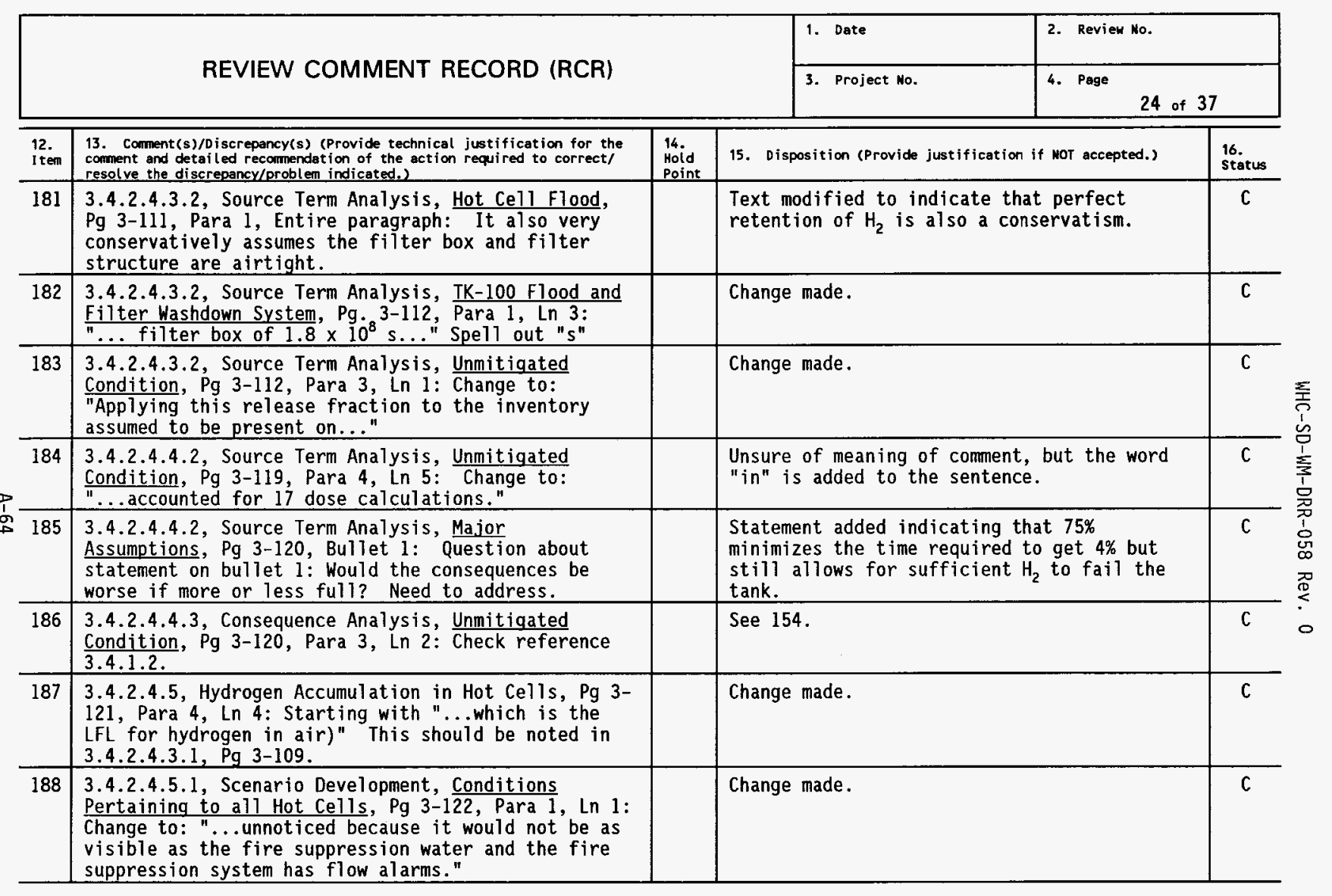




\begin{tabular}{|l|l|}
\hline 1. Date & 2. Review No. \\
\hline 3. Project No. & 4. Page 25 of 37 \\
\hline
\end{tabular}

\begin{tabular}{|c|c|c|c|c|}
\hline $\begin{array}{l}12 . \\
\text { Item }\end{array}$ & $\begin{array}{l}\text { 13. Comment(s)/Discrepancy(s) (Provide technical justification for the } \\
\text { comment and detailed recomendation of the action required to correct/ } \\
\text { resolve the discrepancy/problem indicated.) }\end{array}$ & $\begin{array}{l}14 . \\
\text { Hold } \\
\text { Point }\end{array}$ & 15. Disposition (Provide justification if NOT accepted.) & $\begin{array}{l}\text { 16. } \\
\text { Status }\end{array}$ \\
\hline 189 & 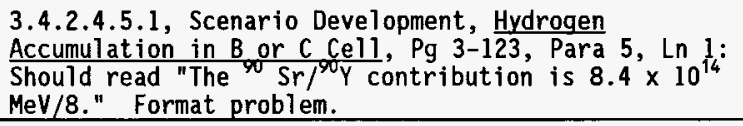 & & Could not find format problem. & C \\
\hline 190 & $\begin{array}{l}\text { 3.4.2.4.5.1, Scenario Development, Hydrogen } \\
\text { Accumulation in } \mathrm{D} / \mathrm{E} \text { Cell, } \mathrm{Pg} 3-125: \text { Question } \\
\text { regarding calculations at bottom of page: Are the } \\
\text { detailed calculations documented? They should be. }\end{array}$ & & $\begin{array}{l}\text { Detailed calcs. not shown because they were } \\
\text { shown once for } B / C \text { Cell. They are } \\
\text { reproducible so showing them again was } \\
\text { considered redundant. }\end{array}$ & C \\
\hline 191 & $\begin{array}{l}\text { 3.4.2.4.5.2, Source Term Analysis, Unmitigated } \\
\text { Condition, Pg 3-127, Para } 1 \text {, Ln 2: Change to: "F } \\
\text { Cell has been analyzed to store as many as } 24 \\
\text { capsules..." }\end{array}$ & & $\begin{array}{l}\text { Text changed to read " } F \text { Cell has been } \\
\text { analyzed to store as many as } 24 \text { capsules..." }\end{array}$ & C \\
\hline 192 & $\begin{array}{l}\text { 3.4.2.4.5.5, Summary of Safety SSCs and IOSR } \\
\text { Controls, Credited Controls, Pg } 3-128 \text {, Bullet } 4: \\
\text { Question about statement: (2) references what? }\end{array}$ & & $\begin{array}{l}\text { Text changed to read "Alternately to } \\
\text { reestablishing ventilation airflow," }\end{array}$ & C \\
\hline 193 & $\begin{array}{l}\text { 3.4.2.5.1, Scenario Development, } \mathrm{Pg} 3-129 \text {, Para } 1 \text {, } \\
\text { Ln 4: Comment regarding "frequency F". F needs a } \\
\text { numerical value. }\end{array}$ & & Text changed to read "..frequency F2.." & C \\
\hline 194 & $\begin{array}{l}\text { 3.4.2.5.1, Scenario Development, Pg } 3-129 \text {, Para } 1 \text {, } \\
\text { Ln } 7: \text { Comment for end of paragraph. Need to add a } \\
\text { sentence on risk value. }\end{array}$ & & $\begin{array}{l}\text { Text changed to read "The resulting risk } \\
\text { rank for this accident is R3 (items of major } \\
\text { concern)." }\end{array}$ & C \\
\hline 195 & $\begin{array}{l}\text { 3.4.2.5.1, Scenario Development, Unmitigated } \\
\text { Condition, Pg } 3-129, \text { Para } 3, \text { Ln } 6 \text { : Change to: "... a } \\
\text { result of wind or infiltration. }\end{array}$ & & $\begin{array}{l}\text { Text changed to read "...a result of wind or } \\
\text { infiltration." }\end{array}$ & C \\
\hline 196 & $\begin{array}{l}\text { 3.4.2.5.1, Scenario Development, Unmitigated } \\
\text { Condition, Pg 3-129, Para 2, Ln 16: Change to: } \\
\text { "...section 3.4.2.6.2." }\end{array}$ & & Text changed to read "...section 3.4.2.6.2." & $\mathrm{C}$ \\
\hline 197 & $\begin{array}{l}\text { 3.4.2.5.1, Scenario Development, Unmitigated } \\
\text { Condition, Pg } 3-130 \text {, Para } 3, \text { Ln } 2 \text { : Comment about } \\
\text { "pool cell liner" If pool cell liner is damaged, } \\
\text { the loss of water is } 1 \text { " or } 60 \text { gallons. I think this } \\
\text { implies worse consequences, which are what? }\end{array}$ & & $\begin{array}{l}\text { Section } 3.4 .2 .5 .1 \text {, Unmitigated Condition } \\
\text { says "If the building does collapse, large } \\
\text { structural members could fall into the pool } \\
\text { cells damaging capsules and possibly the } \\
\text { pool cell liner and underlying structure." }\end{array}$ & C \\
\hline
\end{tabular}




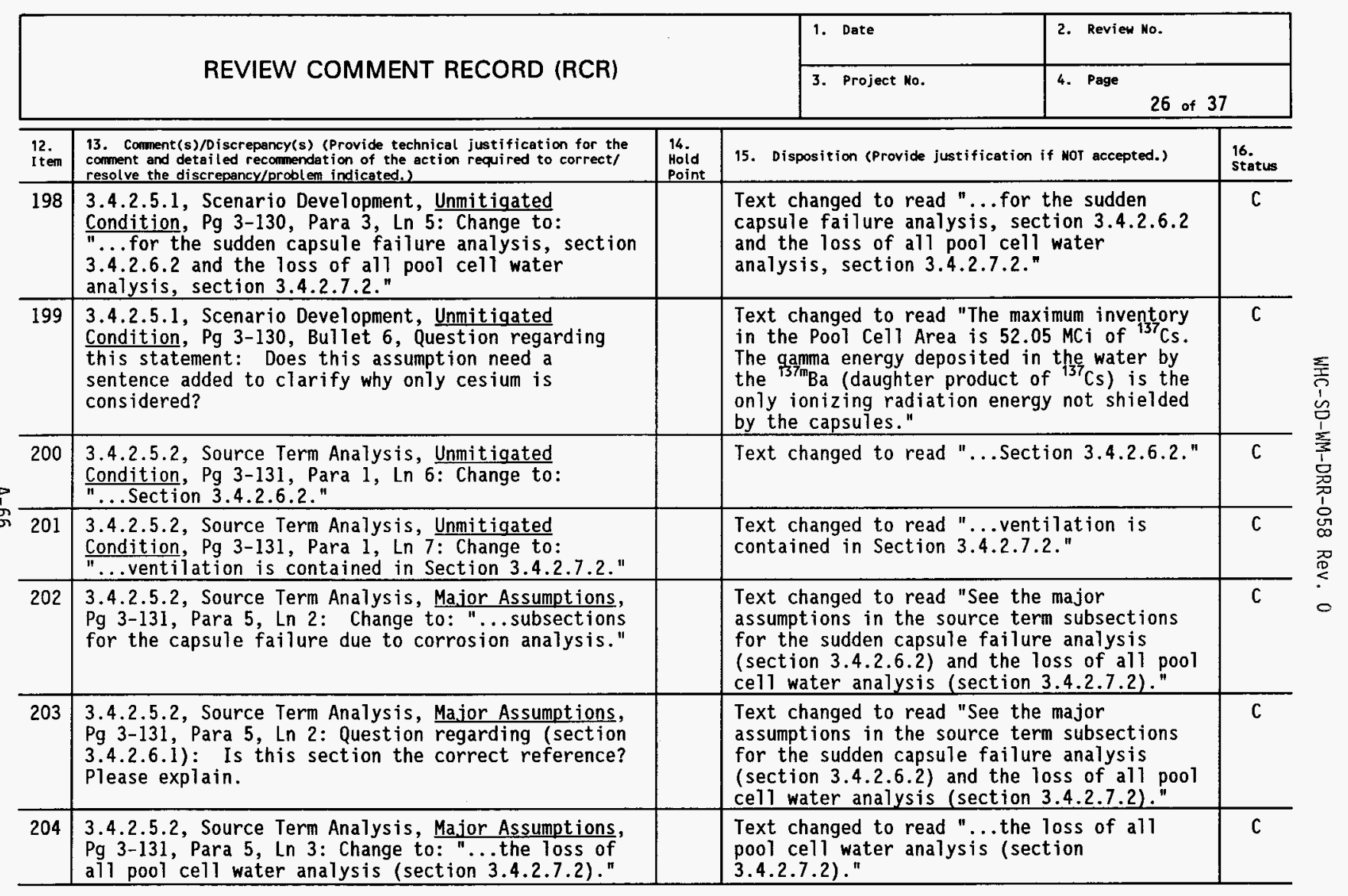




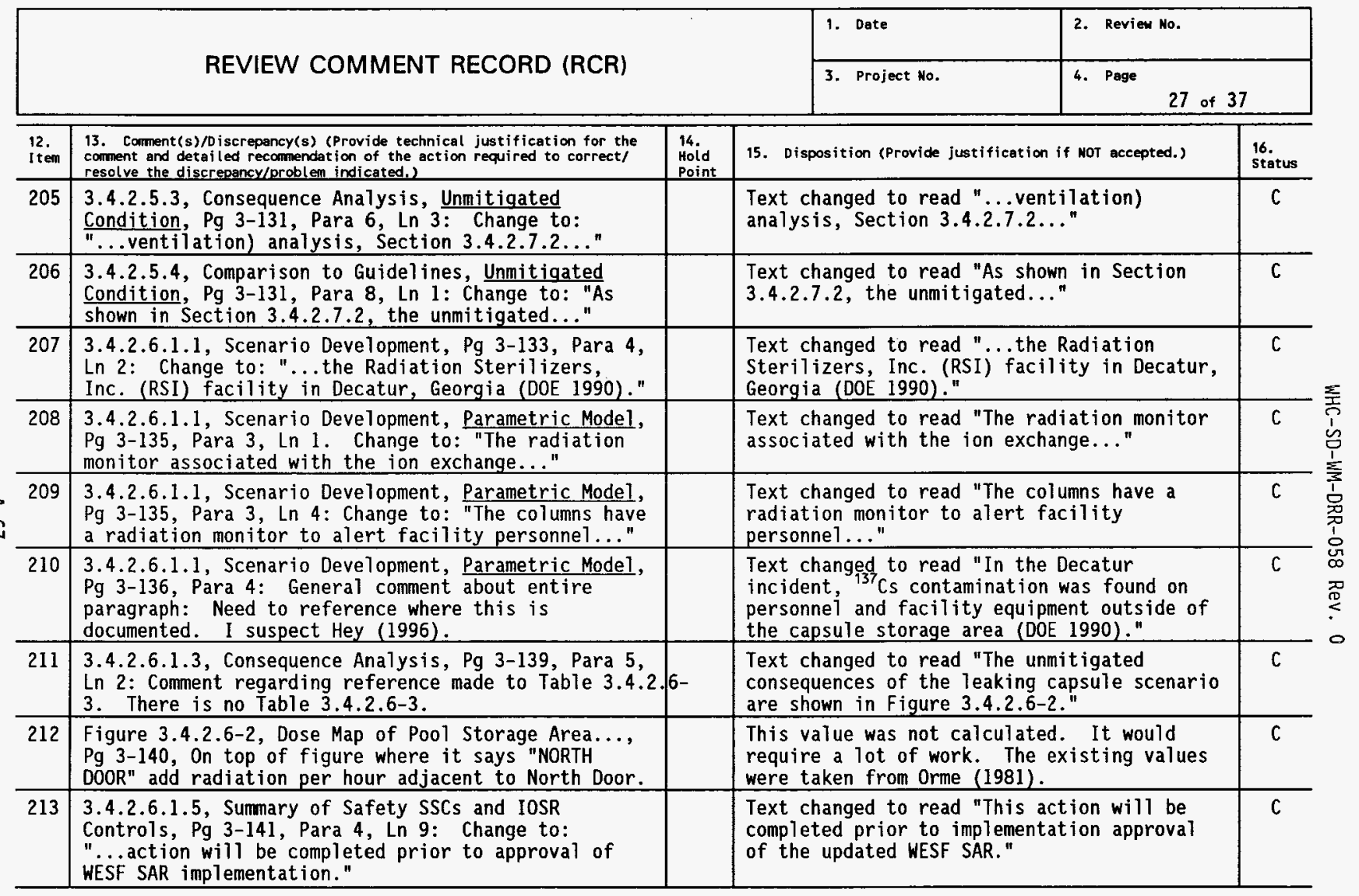




\begin{tabular}{|l|l|l|}
\hline \multirow{2}{*}{ REVIEW COMMENT RECORD (RCR) } & 1. Date & Review No. \\
\cline { 2 - 3 } & 3. Project No. & 4. Page 28 of 37 \\
\hline
\end{tabular}

\begin{tabular}{|c|c|c|c|c|}
\hline $\begin{array}{l}12 . \\
\text { Item }\end{array}$ & $\begin{array}{l}\text { 13. Comment(s)/Discrepancy(s) (Provide technical justification for the } \\
\text { comment and detailed recommencation of the action required to correct/ } \\
\text { resolve the discrepancy/problem indicated.) }\end{array}$ & $\begin{array}{l}14 . \\
\text { Mold } \\
\text { Point }\end{array}$ & 15. Disposition (Provide justification if NOT accepted.) & $\begin{array}{l}\text { 16. } \\
\text { Status }\end{array}$ \\
\hline 214 & $\begin{array}{l}3.4 .2 .6 .2 .1 \text {, Scenario Development, Pg } 3-142 \text {, Para } 6 \text {, } \\
\text { Item } 1 \text { : Change to: "1. a breach of the pool cell } \\
\text { liner and structure" }\end{array}$ & & $\begin{array}{l}\text { Text changed to read "• a breach of the } \\
\text { pool cell liner and structure," }\end{array}$ & C \\
\hline 215 & $\begin{array}{l}\text { 3.4.2.6.2.1, Scenario Development, Pg } 3-142 \text {, Para } 7 \text {, } \\
\text { Ln 4: Statement starting with "Additionally, the } \\
\text { integrity of" is in direct conflict with statement } \\
\text { on Pg 3-147, 'Pool Cel1 Liner Leak Due to Corrosion, ' } \\
\text { Para 2, last sentence. }\end{array}$ & & Text was fixed. & C \\
\hline 216 & $\begin{array}{l}3.4 .2 .6 .2 .3 \text {, Consequence Analysis, } \mathrm{Pg} 3-145 \text {, Para } 6 \text {, } \\
\text { Ln 2: Comment regarding Table referenced in this } \\
\text { sentence (Table } 3.4 .2 .6-3 \text { ). Couldn't find this } \\
\text { table. }\end{array}$ & & $\begin{array}{l}\text { Text changed to read "... the dissolution of } \\
\text { the maximum cesium capsule is provided in } \\
\text { Figure } 3.4 .2 .6-2 \text {." }\end{array}$ & C \\
\hline 217 & $\begin{array}{l}\text { 3.4.2.7.1.1, Scenario Development, } \mathrm{Pg} 3-146 \text {, Para } 4 \text {, } \\
\text { Ln } 11 \text { : Change to: "The more severe consequences from } \\
\text { this event are discussed in..." }\end{array}$ & & $\begin{array}{l}\text { Text changed to read "The more severe } \\
\text { consequences from this event are discussed } \\
\text { in..." }\end{array}$ & C \\
\hline 218 & $\begin{array}{l}3.4 .2 .7 .1 .1 \text {, Scenario Development, Pool Cell Liner } \\
\text { Leak Due to object Drop/Impact, Pg } \frac{148, \text { Para } 1,}{3-148} \\
\text { Ln 6: Change to: "... Teak and structural failure } \\
\text { caused by a cover biock drop..." }\end{array}$ & & $\begin{array}{l}\text { Text changed to read "... leak and structural } \\
\text { failure caused by a cover block drop..." }\end{array}$ & C \\
\hline 219 & $\begin{array}{l}3.4 .2 .7 .1 .1 \text {, Scenario Development, Pool Cell Liner } \\
\text { Leak Due to Object Drop/Impact, Pg } \frac{\text { Old8, Para } 2,}{3-148} \\
\text { Ln } 7: \text { Change to: "...connected through valves to a } \\
\text { header pipe located above the pool cell floor } \\
\text { grating..." }\end{array}$ & & $\begin{array}{l}\text { Text changed to read "... connected through } \\
\text { valves to a header pipe located above the } \\
\text { pool cell floor grating..." }\end{array}$ & $\mathrm{C}$ \\
\hline 220 & $\begin{array}{l}3.4 .2 .7 .1 .1 \text {, Scenario Development, Pool Cell Liner } \\
\text { Leak Due to Object Drop/Impact, Pg } \frac{\text { Oble }}{3-148 \text {, Para 4, }} \\
\text { Ln 1: Delete entire first sentence that begins "A } \\
\text { conductivity probe leak detector" }\end{array}$ & & $\begin{array}{l}\text { All references to a leak detector in the } \\
\text { pipe tunnel have been removed. }\end{array}$ & C \\
\hline 221 & $\begin{array}{l}\text { 3.4.2.7.1.1, Scenario Development, Pool Cell Liner } \\
\text { Leak Due to Object Drop/Impact, Pg } \frac{3-148, \text { Para } 4,}{\text { Ln 6: Delete entire sentence that begins, "The }} \\
\text { failure probability of a probe type leak..." }\end{array}$ & & See 220 . & C \\
\hline
\end{tabular}




\begin{tabular}{|l|l|l|l|}
\hline \multirow{2}{*}{ REVIEW COMMENT RECORD (RCR) } & 1. Date & Review Ho. \\
\cline { 2 - 4 } & 3. Project No. & $4 . \quad$ Page \\
\hline
\end{tabular}

\begin{tabular}{|c|c|c|c|c|}
\hline $\begin{array}{l}12 . \\
\text { Item }\end{array}$ & $\begin{array}{l}\text { 13. Comment(s)/Discrepancy(s) (Provide technical justification for the } \\
\text { comment and detailed recommendation of the action required to correct/ } \\
\text { resolve the discrepancy/problem indicated.) }\end{array}$ & $\begin{array}{l}14 . \\
\text { Hold } \\
\text { Point }\end{array}$ & 15. Disposition (Provide justification if NOT accepted.) & $\begin{array}{l}16 . \\
\text { Status }\end{array}$ \\
\hline 222 & $\begin{array}{l}3.4 .2 .7 .1 .1 \text {, Scenario Development, Pool Cell Liner } \\
\text { Leak Due to Object Drop/Impact, Pg } \frac{149 \text {, Para } 1 \text {, }}{3-149} \\
\text { Entire Paragraph: Question on paragraph: Where are } \\
\text { these numbers documented? }\end{array}$ & & $\begin{array}{l}\text { The dose rate is stated to come from Section } \\
3.4 .2 .6 .2 .3 \text { where it is referenced there. } \\
\text { Cover block weights come from WESF essential } \\
\text { drawings as does the pool cell foundation } \\
\text { thickness. WESF essential drawings were not } \\
\text { referenced per request of the WESF Cognizant } \\
\text { engineers. }\end{array}$ & C \\
\hline 223 & 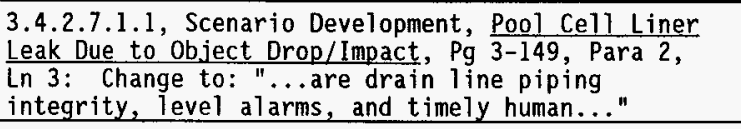 & & $\begin{array}{l}\text { Text changed to read "...are drain line } \\
\text { piping integrity, level alarms, and timely } \\
\text { human..." }\end{array}$ & C \\
\hline 224 & $\begin{array}{l}\text { 3.4.2.7.1.1, Scenario Development, Inadvertent } \\
\text { Draining, Pg 3-149, Para 4, Ln } 11: \text { Comment on } \\
\text { sentence which begins, "The water } 1 \text { eve } 1 \\
\text { surveillance..." The new SR is once every } 8 \text { hours. }\end{array}$ & & $\begin{array}{l}\text { Reference to specific surveillance } \\
\text { frequencies have been removed. }\end{array}$ & C \\
\hline 225 & $\begin{array}{l}3.4 .2 .7 .1 .2 \text {, Source Term Analysis, Thermal Analysis, } \\
\text { Pg } 3-150 \text {, Para } 5 \text {, Ln } 5: \text { Change to: "...of liner } \\
\text { corrosion and structural failure, drop, pipe } \\
\text { failure,..." }\end{array}$ & & $\begin{array}{l}\text { Text changed to read "... of } 1 \text { iner corrosion } \\
\text { and structural failure, drop, pipe } \\
\text { failure,..." }\end{array}$ & c \\
\hline 226 & 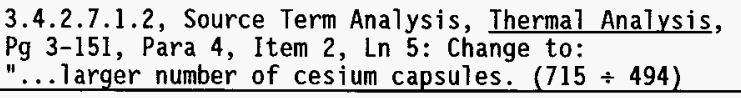 & & $\begin{array}{l}\text { Text changed to read ".. } 7 \text { arger number of } \\
\text { cesium capsules (i.e., } 715 \text { vs. 494)." }\end{array}$ & C \\
\hline 227 & $\begin{array}{l}\text { Table } 3.4 .2 .7-1 \text {, Single Pool Water Loss Event Source } \\
\text { Terms, Pg } 3-153 \text {, Column } 3 \text {, Rows } 3,4,5: \text { General } \\
\text { comment on data in these } 3 \text { rows: "13 days, } 28 \text { days, } \\
13 \text { days" Need to discuss where release period } \\
\text { figures come from. }\end{array}$ & & $\begin{array}{l}\text { Footnote was added to the table to discuss } \\
\text { where release period figures come from. }\end{array}$ & C \\
\hline 228 & $\begin{array}{l}\text { Table 3.4.2.7-1, Single Pool Water Loss Event Source } \\
\text { Terms, Pg 3-153, Column 1, Row 5: "stuck on } \\
\text { filter". Comment: what is this? }\end{array}$ & & $\begin{array}{l}\text { Text changed to read "...Captured on } \\
\text { Fi1ter)". }\end{array}$ & C \\
\hline
\end{tabular}




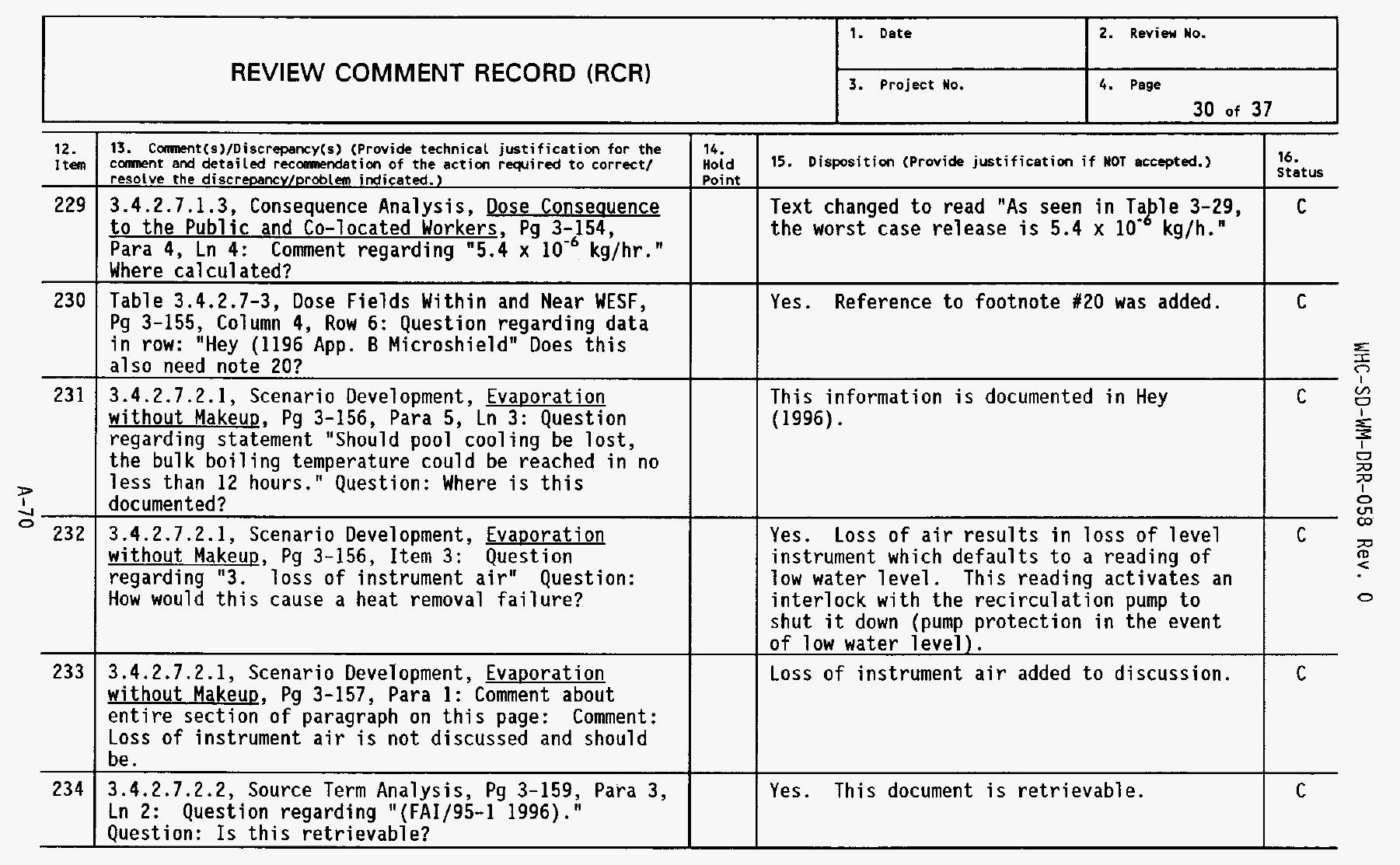




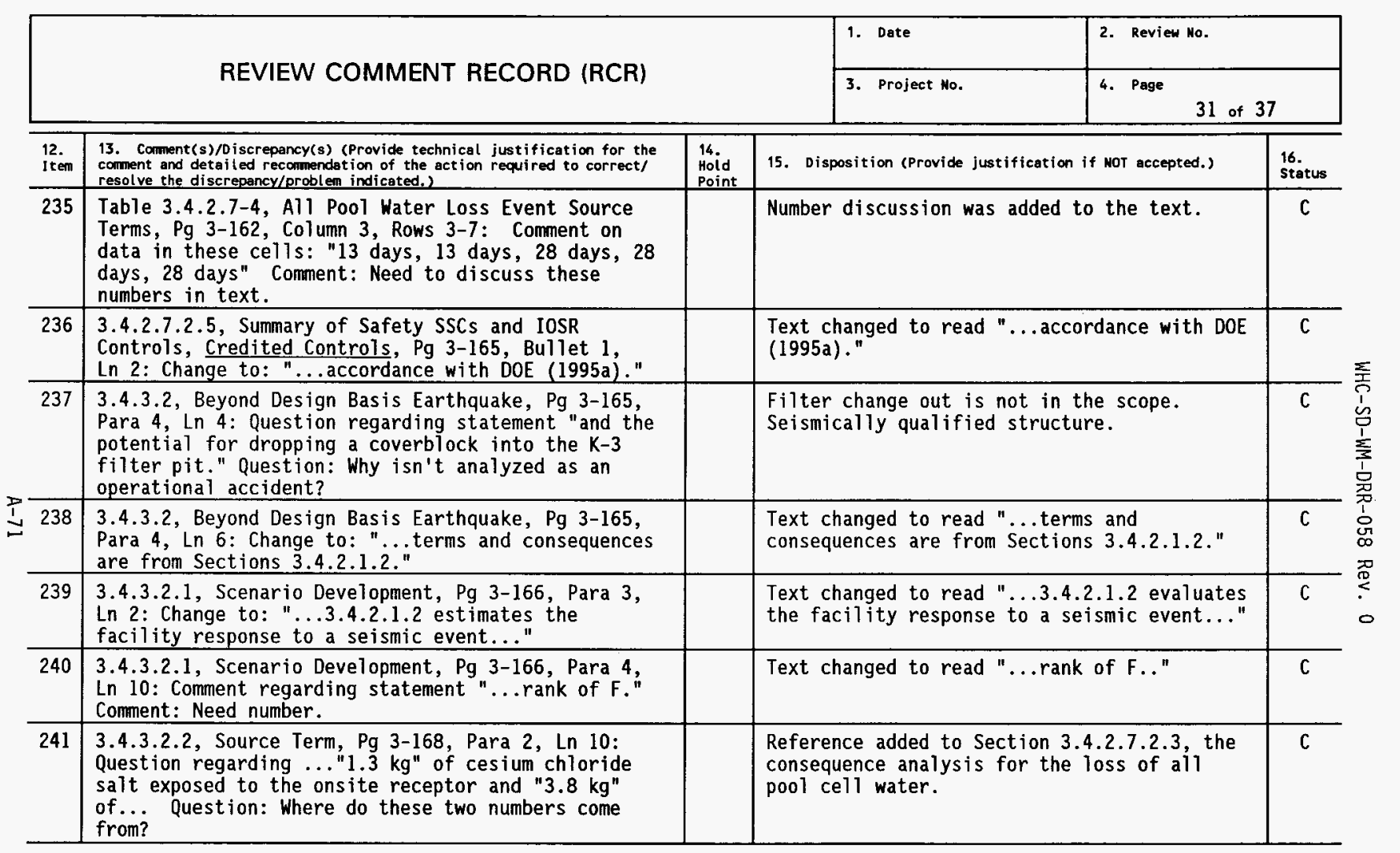




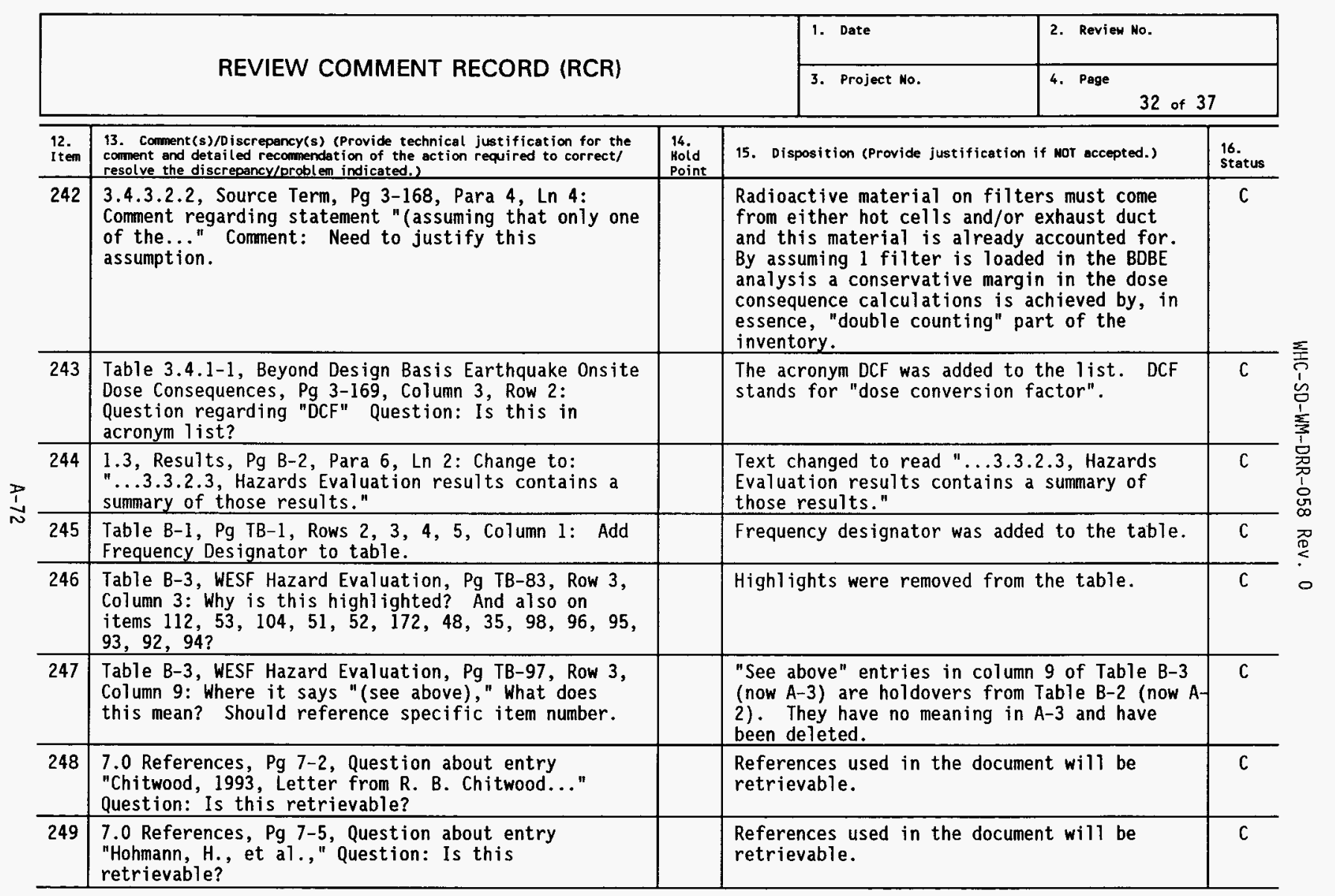


REVIEW COMMENT RECORD (RCR)

1. Date
3. Project No.

3. Project No.
2. Review No.

4. Page

33 of 37

\begin{tabular}{|c|c|c|c|c|}
\hline $\begin{array}{l}12 . \\
\text { I tem }\end{array}$ & $\begin{array}{l}\text { 13. Comment(s)/Discrepancy(s) (Provide technical justification for the } \\
\text { comment and detailed recommendation of the action required to correct/ } \\
\text { resolve the discrepancy/problem indicated.) }\end{array}$ & $\begin{array}{l}14 . \\
\text { Hoid } \\
\text { Point }\end{array}$ & 15. Disposition (Provide justification if NOT accepted.) & $\begin{array}{l}16 . \\
\text { Status }\end{array}$ \\
\hline 250 & $\begin{array}{l}7.0 \text { References, } \mathrm{Pg} 7-5 \text {, Question about entry } \\
\text { "Holten, R. A. 1994," Question: Is this retrievable? }\end{array}$ & & $\begin{array}{l}\text { References used in the document will be } \\
\text { retrievable. }\end{array}$ & C \\
\hline 251 & $\begin{array}{l}7.0 \text { References, pg 7-7, Question about entry } \\
\text { "Schreckhise, R. G.," Question: Is this retrievable? }\end{array}$ & & $\begin{array}{l}\text { References used in the document will be } \\
\text { retrievable. }\end{array}$ & C \\
\hline 252 & $\begin{array}{l}\text { 7.0 References, } \mathrm{Pg} 7-7 \text {, Question about entry } \\
\text { "Terrones, 6., 1995, " Question: Is this retrievable? }\end{array}$ & & $\begin{array}{l}\text { References used in the document will be } \\
\text { retrievable. }\end{array}$ & C \\
\hline 253 & $\begin{array}{l}\text { 7.0 References, } \mathrm{Pg} 7-10 \text {, Question about entry } \\
\text { "WHC-SP-1164, WHC Safety Analysis Reports and } \\
\text { Technical..." Question: Does this entry need date? }\end{array}$ & & $\begin{array}{l}\text { No. Revisions will be indicated by a } \\
\text { revision number which would indicate a date. }\end{array}$ & C \\
\hline 254 & $\begin{array}{l}7.0 \text { References, } \mathrm{Pg} 7-10 \text {, Question about entry } \\
\text { "Compliance Assessment and Implementation Plan for } \\
\text { DOE Order } 5480.24 \ldots \text { "Question: Is this } \\
\text { retrievable? }\end{array}$ & & $\begin{array}{l}\text { References used in the document will be } \\
\text { retrievable. }\end{array}$ & C \\
\hline 255 & $\begin{array}{l}\text { 7.0 References, } \mathrm{Pg} 7-10 \text {, Comment about entry "WESF } \\
\text { Standards and Requirements Ident ification } \\
\text { Document..." Comment: This needs SD number. }\end{array}$ & & $\begin{array}{l}\text { The document has been assigned a number, } \\
\text { WHC-SD-MP-SRID-007. }\end{array}$ & C \\
\hline
\end{tabular}




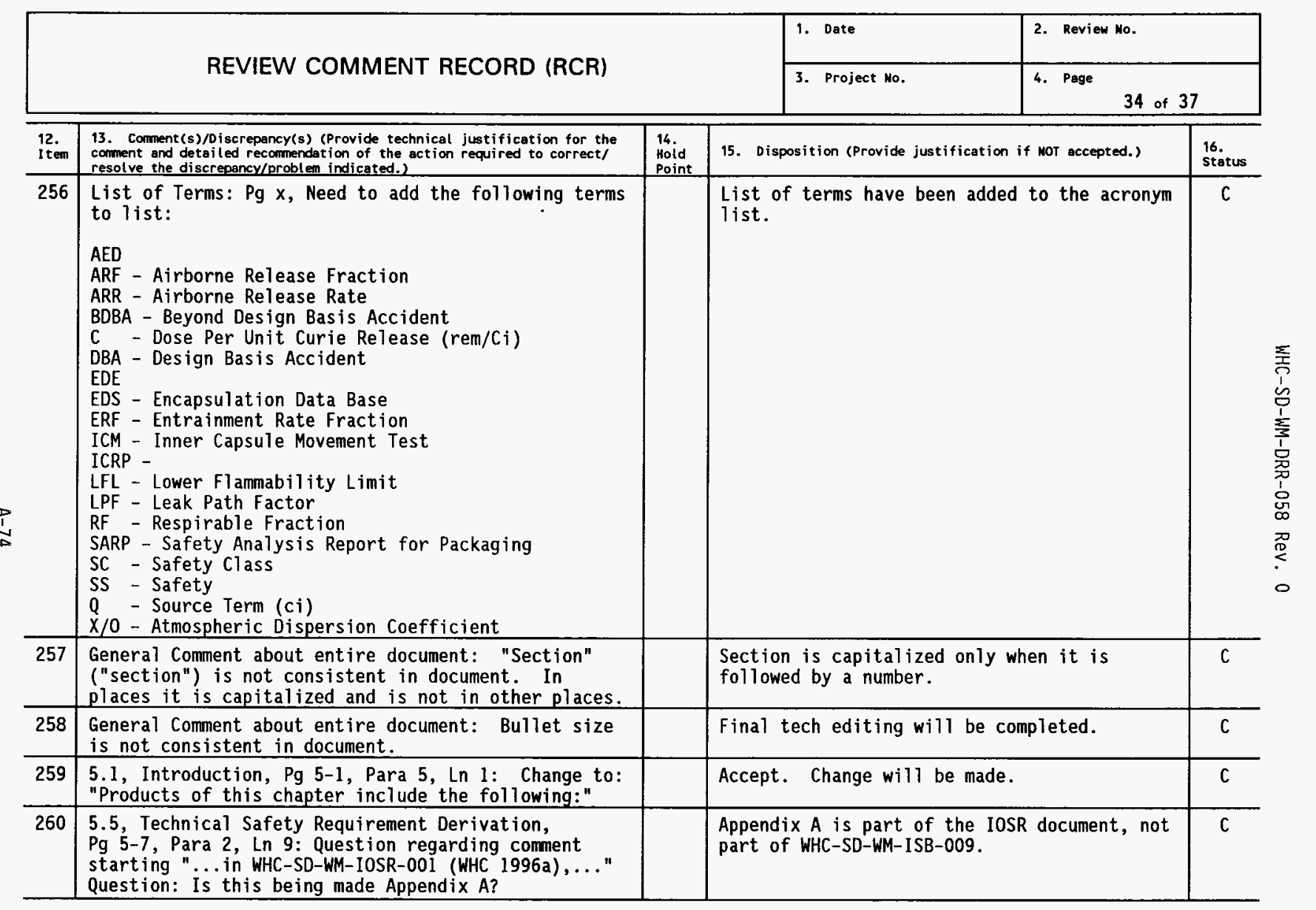




\section{REVIEW COMMENT RECORD (RCR)}

\begin{tabular}{|l|l|}
\hline 1. Date & 2. Review No. \\
\hline 3. Project No. & 4. Page 35 of 37 \\
\hline
\end{tabular}

\begin{tabular}{l|l|l|}
\hline 12. & 13. & Comment (s)/Discrepancy(s) (Provide technical justification for the \\
I tem & comment and detafled recommendation of the action required to correct)
\end{tabular} comment and detailed recommendation of the action required to correct/ Hold resolve the discrepancy/problem indicated.)

261 5.6, Design Features, 225-B Building, Pg 5-8, Bullet 7, Ln 2: Change to: "...at several locations in the hot cells to provide shielding from radioactive material."

262 5.7.2, Facilities Affected by the WESF Safety Basis, Pg 5-10, Para 1, Ln 1: Question regarding "5.7.2.1 B Plant." Question: Is this correct?

263 6.4.1, Conduct of Operations, Pg 6-11, Para 6, Comment regarding entire section: Comment: Need to state the plant specific Conduct of Operations requirements are in WHC-IP-1182, B Plant/WESF Conduct of Operations.

264 6.7.1, Initial Testing, Pg 6-21, Para 7 \& 8, Comment regarding this section. Comment: Should reference WHd-CM-61, Standard Engineering Practices, E.P-4.2, "Testing Requirements." Another comment regarding this section: Comment: Rewrite entire section based on $E . P$ 4.2.

2656.7 .2 , In-Service Surveillance and Maintenance Program, Pg 6-22, Para 3, Comment regarding entire paragraph: Comment: Rewrite Maintenance Program, discuss with Gail Rensink on 372-0092.

266 6.7.2, In-Service Surveillance and Maintenance Program, Pg 6-22, Para 3, Comment on entire paragraph: Comment: Rewrite Surveillance Program based on John Townley's input.

267 6.9.1, Organizational Structure, Responsibilities and Interfaces, Pg 6-23, Para 7, Ln 2: Change to: "Each member of the WESF teams is accountable for..."

15. Disposition (Provide justification if NOT accepted.)

Accept. Change will be made as modified: "... at several locations in the Hot Cell Area and Canyon Area to provide...."

Yes. This information is taken from the $B$ Plant ISB.

A reference to WHC-CM-5-6 and WHC-IP-1182 has been provided at the end of 12 in Section 6.0 .

WHC-CM-6-1 has been added to Table 6-1, Row $\# 7$.

J. Townley unavailable, L. Covey provided review and revisions.

J. Townley unavailable, L. Covey provided review and revisions. Gail Rensink reviewed has had no comments.

J. Townley unavailable, L. Covey provided review and revisions.

16. Status

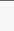




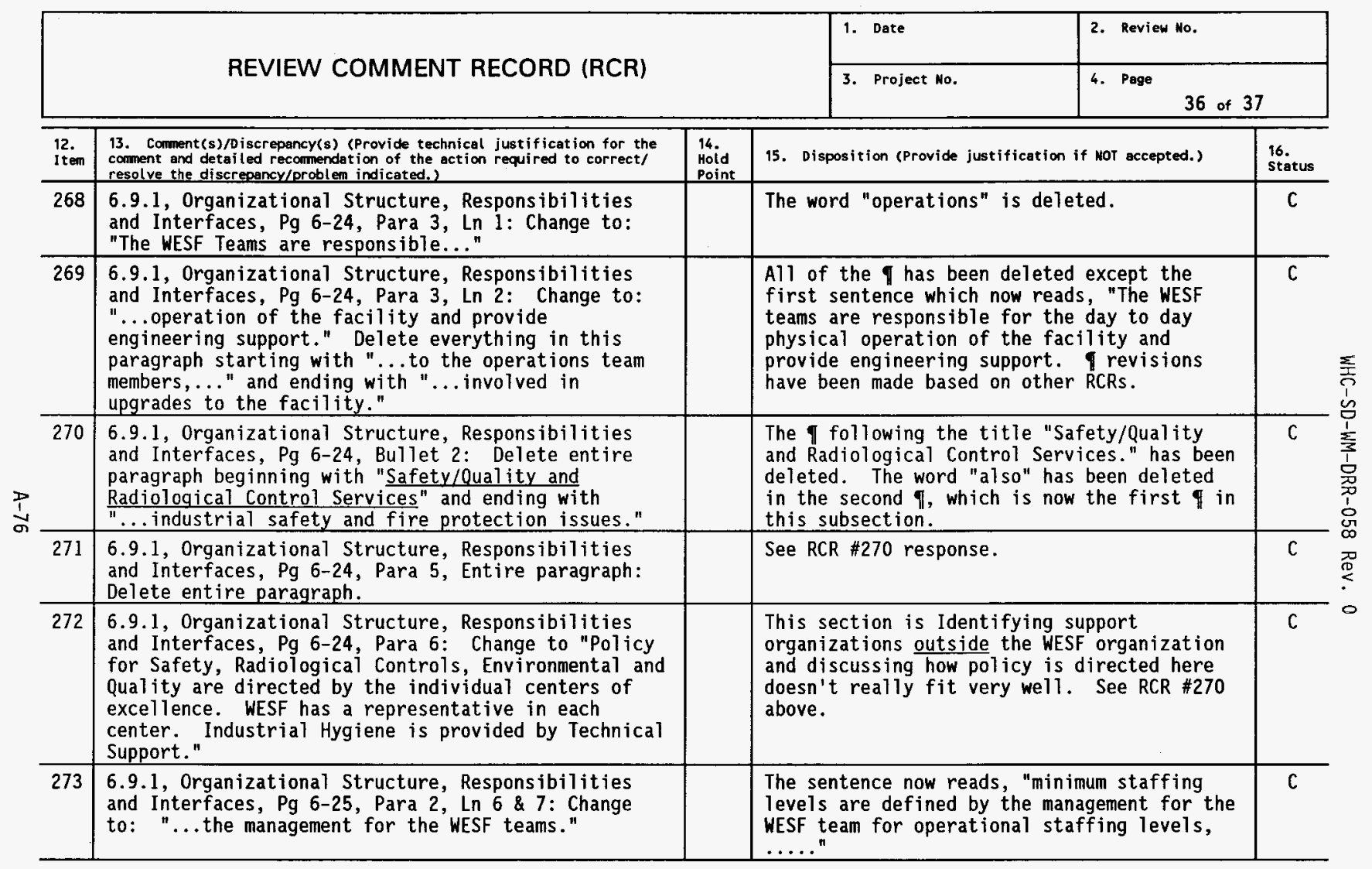




\begin{tabular}{|l|l|}
\hline 1. Date & 2. Review Mo. \\
\hline 3. Project No. & 4. Page 37 of 37 \\
\hline
\end{tabular}

12. 13. Comment(s)/0 iscrepancy(s) (Provide technical justification for the

\begin{tabular}{|l|l|l|l}
\hline 14. & 15. Disposition (Provide justification if not accepted.) &
\end{tabular}
Item comment and detailed recommendation of the action required to correct/ resolve the discrepancy/problem indicated.)

274 6.9.2, Safety Management Policies and Programs, Pg 625, Para 4, Ln 5: Delete "Regular safety inspections conducted by all levels of management identify safety and housekeeping deficiencies. Deficiencies are tracked and status reports are completed and reviewed on a monthly basis."

275 6.9.2, Safety Management Policies and Programs, Pg 625, Para 5, Ln 6: Comment on last sentence: "The WESF operations program also practices safety record management and control which is the documented process used to provide facility specific management and control of safety documentation for the WESF facility and operations." Comment: What is this?

6.9.2, Safety Management Policies and Programs, Pg 626, Para 1, Comment on entire paragraph: Comment: Reference WHC-CM-5-6, Section 5.43.

277 6.9.2, Safety Management Policies and Programs, Pg 626, Para 2, Comment on entire paragraph: Comment: Rewrite paragraph based on 6.7.2.

278 6.9.2, Safety Management Policies and Programs, Pg 626, Para 5, Entire paragraph: Comment: Reference WHC-CM-56, Section 5.4. Rewrite based on synopsis of 5.4. Hold Point

Lines 6,7 , and 8 beginning with "Regular safety inspections......" through the end of the $\mathbb{T}$ have been deleted.

$+$

\begin{tabular}{|l} 
\\
\hline \\
$-C M-5-$
\end{tabular}

The sentence has been deleted.

WHC-CM-5-6 is referenced in 6.0 .

No change, G. Rensink had no "issues."

WHC-CM-5-6 is referenced in 6.0. This section was designed to follow as closely as possible in summary the Chapter 17 of Standard 3009 . Section 5.4 of the CM-5-6 is ALARA only. Alara is discussed in section 6.1.2 and 6.2.1.

279 6.9.2, Safety Management Policies and Programs, Pg 627, Para 1, Entire paragraph: Comment: Rewrite based on input from Gail Rensink.
16. C
G. Rensink reviewed the chapter and had no comments. 
WHC-SD-WM-DRR-058 Rev. 0

This page intentionally left blank. 


\section{REVIEW COMMENT RECORD (RCR)}

\begin{tabular}{|l|l|}
\hline \begin{tabular}{|l|} 
1. Date $09 / 04 / 96$ \\
3. Project No.
\end{tabular} & 2. Review No. \\
\hline & 4. Page 1 of 4 \\
\hline
\end{tabular}

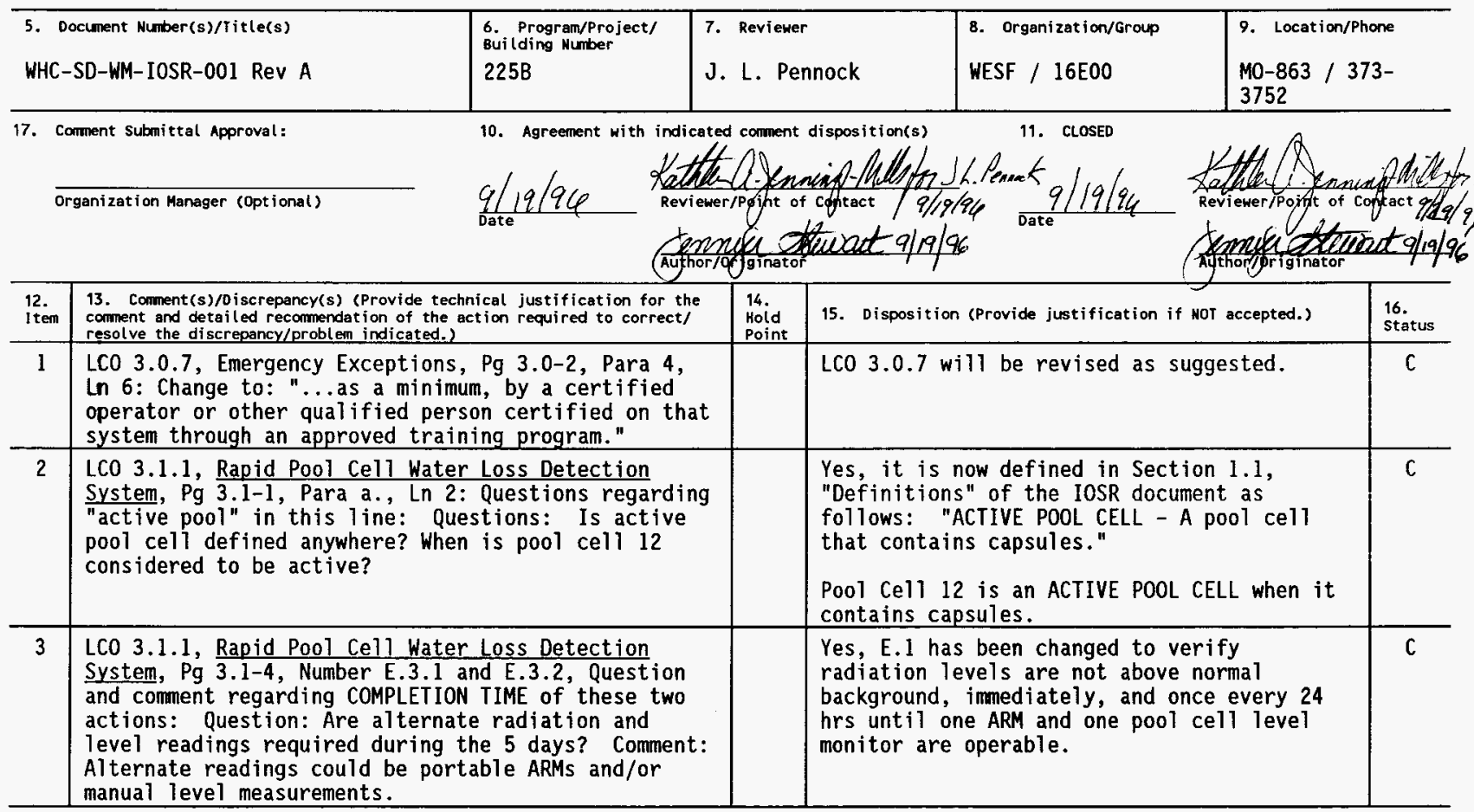




\begin{tabular}{|l|l|l|}
\hline \multirow{2}{*}{ REVIEW COMMENT RECORD (RCR) } & $\begin{array}{l}\text { 1. Date } 09 / 04 / 96 \\
\text { 2. Review No. }\end{array}$ \\
\cline { 2 - 3 } & 3. Project No. & 4. Page 2 of 4 \\
\hline
\end{tabular}

\begin{tabular}{|c|c|c|c|c|}
\hline $\begin{array}{l}12 . \\
\text { Item }\end{array}$ & $\begin{array}{l}\text { 13. Comment(s)/Discrepancy(s) (Provide technical justification for the } \\
\text { comment and detailed recommendation of the action required to correct/ } \\
\text { resolve the discrepancy/problem indicated.) }\end{array}$ & $\begin{array}{l}14 . \\
\text { Hold } \\
\text { Point }\end{array}$ & 15. Disposition (Provide justification if NOT accepted.) & $\begin{array}{l}16 . \\
\text { Status }\end{array}$ \\
\hline 4 & $\begin{array}{l}\text { 5.3.1, Pg. 5.3-1, Para a., Ln 1: Change to: } \\
\text { "Operating within the Limiting Conditions for } \\
\text { Operation (LCOS) and the associated Surveillance } \\
\text { Requirements (SRs) during their Applicability." } \\
\text { Comment regarding this paragraph: Recommend deleting } \\
\text { references to SLS \& LCSs since there are none. }\end{array}$ & & 5.3.1 will be revised as suggested. & C \\
\hline 5 & $\begin{array}{l}\text { 5.4.1, VIOLATION Criteria, Pg 5.4-1, Para a. Entire } \\
\text { Line: DeTete following comment: "Exceeding an SL." } \\
\text { Comment: Recommend deleting since there are no SLs. }\end{array}$ & & $\begin{array}{l}\text { No changes made in this section. References } \\
\text { to SLs/LCSs will be deleted in more } \\
\text { appropriate places. It is best to keep the } \\
\text { SL/LCS criteria intact for IOSR/TSR } \\
\text { selection for any new analyses in the } \\
\text { future. This section is also verbatim from } \\
\text { DOE } 5480.22 \text {. }\end{array}$ & C \\
\hline 6 & $\begin{array}{l}\text { 5.4.1, VIOLATION Criteria, Pg 5.4-1, Para 1., Entire } \\
\text { Line: Delete following comment: "Exceeding an LCS." } \\
\text { Comment: Recommend deleting since there are no LCSs. }\end{array}$ & & See disposition to comment $\# 5$. & C \\
\hline 7 & $\begin{array}{l}5.4 .2 \text {, Response to a Safety Limit VIOLATION, } \\
\text { Pg } 5.4-2 \text {, Entire Page: Delete entire page. } \\
\text { Comment: Recommend deleting section since there are } \\
\text { no SLs. }\end{array}$ & & $\begin{array}{l}\text { Section } 5.4 .2 \text { items a through e will be } \\
\text { deleted and a paragraph will be added to } \\
\text { this section that states: "No SLs are } \\
\text { identified for WESF based on the selection } \\
\text { criteria in Section } 1.7 \text {, Safety Limits, and } \\
\text { the conclusions found in WHC-SD-WM-BIO-002, } \\
\text { Chapter } 3.0 . "\end{array}$ & C \\
\hline 8 & $\begin{array}{l}5.4 .3 \text {, Response to a Limiting Condition for } \\
\text { Operation and Limiting Control Setting VIOLATION, } \\
\text { Pg 5.4-3, Change Title to: "Response to a Limiting } \\
\text { Condition for Operation and VIOLATION." Comment: } \\
\text { Recommend deletion of reference to Limiting Control } \\
\text { Setting as there are no LCSs. }\end{array}$ & & $\begin{array}{l}\text { The title will remain the same for } \\
\text { consistency with Section } 5.4 .2 \text { and a } \\
\text { paragraph will be added to this section that } \\
\text { states: "Since no SLs are identified for } \\
\text { WESF, there are no LCSs based on the } \\
\text { selection criteria in Section } 1.8 \text {, Limiting } \\
\text { Control Settings." }\end{array}$ & C \\
\hline
\end{tabular}




\begin{tabular}{|c|c|c|c|c|c|}
\hline \multirow{2}{*}{\multicolumn{2}{|c|}{ REVIEW COMMENT RECORD (RCR) }} & & \multirow{2}{*}{$\begin{array}{l}\text { 1. Date } 09 / 04 / 96 \\
\text { 3. Project No. }\end{array}$} & \multicolumn{2}{|l|}{ 2. Review No. } \\
\hline & & & & \multicolumn{2}{|l|}{ 4. Page } \\
\hline $\begin{array}{l}\text { 12. } \\
\text { Item }\end{array}$ & $\begin{array}{l}\text { 13. Corment(s)/Discrepancy(s) (Provide technical justification for the } \\
\text { compent and detail led recompendation of the action required to correct/ } \\
\text { resolve the discrepancy/problem indicated.) }\end{array}$ & $\begin{array}{l}14 . \\
\text { Hoid } \\
\text { Point }\end{array}$ & \multicolumn{2}{|c|}{ 15. Disposition (Provide justification if NOT accepted.) } & $\begin{array}{l}\text { 16. } \\
\text { status }\end{array}$ \\
\hline 9 & $\begin{array}{l}5.4 .3 \text {, Response to a Limiting Condition for } \\
\text { Operation and Limiting Control Setting VIOLATION, Pg } \\
5.4-3 \text {, First sentence, Line 1: Change to: "If a } \\
\text { VIOLATION of an LCO occurs, proceed as follows: " }\end{array}$ & & \multicolumn{2}{|c|}{ Section 5.4 .3 will be revised as suggested. } & c \\
\hline 10 & $\begin{array}{l}\text { 5.8.2, Program Key Elements, Pg 5.8-1, Para a., } \\
\text { Under A Ce11: Question regarding this comment: } \\
\text { "- Maximum } 15,000 \mathrm{Ci} 1{ }^{17} \mathrm{Cs} \text { and }{ }^{90} \mathrm{Sr} \text { (contained in } \\
\text { steel drums) with } 200 \mathrm{~kg} \text { total combustible waste." } \\
\text { Question: Is this limit per drum? }\end{array}$ & & \multicolumn{2}{|c|}{$\begin{array}{l}\text { This is the limit per drum based on the } \\
\text { Safety Analysis Report for Packaging and } \\
\text { Shipping (SARP) but it is still the total } \\
\text { limit for the cell. No changes made. }\end{array}$} & c \\
\hline 11 & $\begin{array}{l}5.8 .2, \frac{K-3 \text { high efficiency particulate air (HEPA) }}{\text { filter system, Pg 5.8-2, Para b., Under Hot Cells }} \\
\text { Questions regarding G Cel1: Questions: How is } \\
\text { "storage" in G Cel1 defined? What if the capsules } \\
\text { are in a cask? }\end{array}$ & & \multicolumn{2}{|c|}{$\begin{array}{l}\text { Storage means either in or out of a cask in } \\
\text { G Cel1. No changes made. }\end{array}$} & c \\
\hline 12 & $\begin{array}{l}5.10 .2 \text {, Program Key Elements, } \mathrm{Pg} 5.10-1 \text {, Para b., } \\
\text { Under builleted items. Lined comments. Comment: } \\
\text { Specify valve numbers. }\end{array}$ & & \multicolumn{2}{|c|}{$\begin{array}{l}\text { Valve numbers will be included in Section } \\
\text { 5.10.2.b. }\end{array}$} & c \\
\hline 13 & $\begin{array}{l}5.10 .2 \text {, Program Key Elements, } \mathrm{Pg} 5.10-2 \text {, First lined } \\
\text { item on page. Comment: Specify valve numbers. }\end{array}$ & & \multicolumn{2}{|c|}{$\begin{array}{l}\text { Valve numbers will be included in Section } \\
5.10 .2 . \text { b. }\end{array}$} & c \\
\hline 14 & $\begin{array}{l}5.11 .2 \text {, Program Key Elements, Pg } 5.11-1 \text {, Following } \\
\text { para b.: Question regarding a section c.: } \\
\text { Question: Should there be a section } 5.11 \text {.2.c which } \\
\text { defines the program elements to control heavy loads } \\
\text { other than coverblocks? }\end{array}$ & & \multicolumn{2}{|c|}{$\begin{array}{l}\text { No, since } 5.11 .2 . b \text { has been reworded to say } \\
\text { "Movement of heavy loads over ACTIVE POOL } \\
\text { CELLS..." }\end{array}$} & c \\
\hline
\end{tabular}




\begin{tabular}{|l|l|l|}
\hline \multirow{2}{*}{ REVIEW COMMENT RECORD (RCR) } & 1. Date & $09 / 04 / 96$ \\
\cline { 2 - 3 } & 3. Project No. & 4. Page \\
\hline
\end{tabular}

\begin{tabular}{|c|c|c|c|c|}
\hline $\begin{array}{l}12 . \\
\text { Item }\end{array}$ & $\begin{array}{l}\text { 13. Comment( }(s) / D \text { iscrepancy(s) (Provide technical justification for the } \\
\text { comment and detailed recommendation of the action required to correct/ } \\
\text { resolve the discrepancy/problem indicated.) }\end{array}$ & $\begin{array}{l}\text { 14. } \\
\text { Hold } \\
\text { Point }\end{array}$ & 15. Disposition (Provide justification if NOT accepted.) & $\begin{array}{l}16 . \\
\text { status }\end{array}$ \\
\hline 15 & $\begin{array}{l}5.13 .2 \text {, Program Key Elements, Pg } 5.13-1 \text {, Para a., } \\
\text { Bullet 2, B-E Cells: Comment regarding following } \\
\text { comment: Plug ports and cover blocks shall remain in } \\
\text { place at all times. Fire suppression capability } \\
\text { shall be provided. Comment: Cell cover blocks need } \\
\text { to be removed for window change-outs. }\end{array}$ & & $\begin{array}{l}\text { Bullet } 2 \text { will be revised to state: "Plug } \\
\text { ports and cover blocks shall remain in place } \\
\text { at all times when stored combustibles are } \\
\text { present. Fire suppression capability shall } \\
\text { be provided." } \\
\text { This is consistent with the analysis per the } \\
\text { analyst. If window change-outs are needed, } \\
\text { just remove the stored combustibles. }\end{array}$ & C \\
\hline 16 & $\begin{array}{l}\text { 5.14.2, Program Key Elements, Pg 5.14-1, Para a., } \\
\text { Line 4: Change entire line to: "WESF Project } \\
\text { Activity Manager." }\end{array}$ & & 5.14.2.a will be revised as suggested. & C \\
\hline 17 & $\begin{array}{l}\text { Appendix A, BASES, Pg A-2, Para } 1 \text {, Ln } 1 \text { : Change to: } \\
\text { "This appendix provides summary statements of the } \\
\text { reasons for the Limiting Conditions for Operation } \\
\text { and the associated Surveillance Requirements." } \\
\text { Comment: Recommend changes since there are no SLs or } \\
\text { LCSs. }\end{array}$ & & This section will be revised as suggested. & C \\
\hline 18 & $\begin{array}{l}\text { BASES LCO, Pg A } 3.1-14 \text {, Para } 1, \text { Ln } 8: \text { Question } \\
\text { regarding "36 inches." Question: Should this read } \\
130 " \text { ? Comment: The first part of this paragraph } \\
\text { states that } 36 " \text { can be reached in } 1 \text { hour. A few } \\
\text { lines later it states that it will take } 7-8 \text { hrs to } \\
\text { drain a pool. This seems contradictory. }\end{array}$ & & $\begin{array}{l}\text { The pool cell water level could gravity } \\
\text { drain to } 36 \text { inches in approximately an hour } \\
\text { upon failure of the drain line if no } \\
\text { mitigating actions are initiated. At a } \\
\text { water level of } 36 \text { inches, it would take } \\
\text { several ( } 7 \text { to } 8 \text { ) hours to evaporate the } \\
\text { water to the top of the capsules } \\
\text { ( } 29 \text { inches). This wording has been included } \\
\text { in the LCO Bases. }\end{array}$ & C \\
\hline
\end{tabular}




\begin{tabular}{|l|l|l|l|}
\hline \multirow{2}{*}{ REVIEW COMMENT RECORD (RCR) } & 1. Date & 2. Review No. \\
\cline { 2 - 4 } & 3. Project No. & 4. Page \\
\hline
\end{tabular}

\begin{tabular}{|c|c|c|}
\hline $\begin{array}{l}\text { 5. Document Number(s)/Title(s) } \\
\text { WHC-Sח-WM-ISB-009 Rev }\end{array}$ & $\begin{array}{l}\text { 6. Program/Project/ } \\
\text { Building Number } \\
\text { WFSF } / 225 R\end{array}$ & 7. Reviewer \\
\hline$W H L-S D-W M-I S B-009$, Rev. 0 & WESF $/ 225 B$ & Gail L. Rensink \\
\hline
\end{tabular}

17. Comment Submittal Approval:

10. Agreement with indicated corment disposition(s)

8. Organization/Group

B Plant/WESF

Transition Project

9. Location/Phone

$271 B / 208 / 200 E$

Organization Manager (Optional)

\section{Date}

Reviewer/Point of Contact

Author/originator

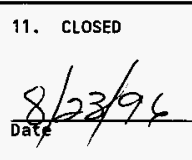

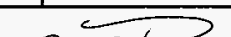

21

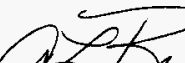
Beviewer/Point of contact L Autkor/originator

\begin{tabular}{|c|c|c|c|c|}
\hline $\begin{array}{l}12 . \\
\text { Item }\end{array}$ & $\begin{array}{l}\text { 13. Comment(s)/Discrepancy(s) (Provide technical justification for the } \\
\text { comment and detailed recomendation of the action required to correct/ } \\
\text { resolve the discrepancy/problem indicated.) }\end{array}$ & $\begin{array}{l}14 . \\
\text { Hoid } \\
\text { Point }\end{array}$ & 15. Disposition (Provide justification if NOT accepted.) & $\begin{array}{l}16 . \\
\text { status }\end{array}$ \\
\hline 1. & I have reviewed Chapter 6 and do not see any issues. & & & \\
\hline & & & & \\
\hline & & & & \\
\hline & & & & \\
\hline & & & & \\
\hline & & & & \\
\hline & & & & \\
\hline & & & & \\
\hline & = & & 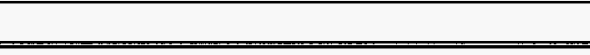 & \\
\hline
\end{tabular}


WHC-SD-WM-DRR-058 Rev. 0

This page intentionally left blank. 


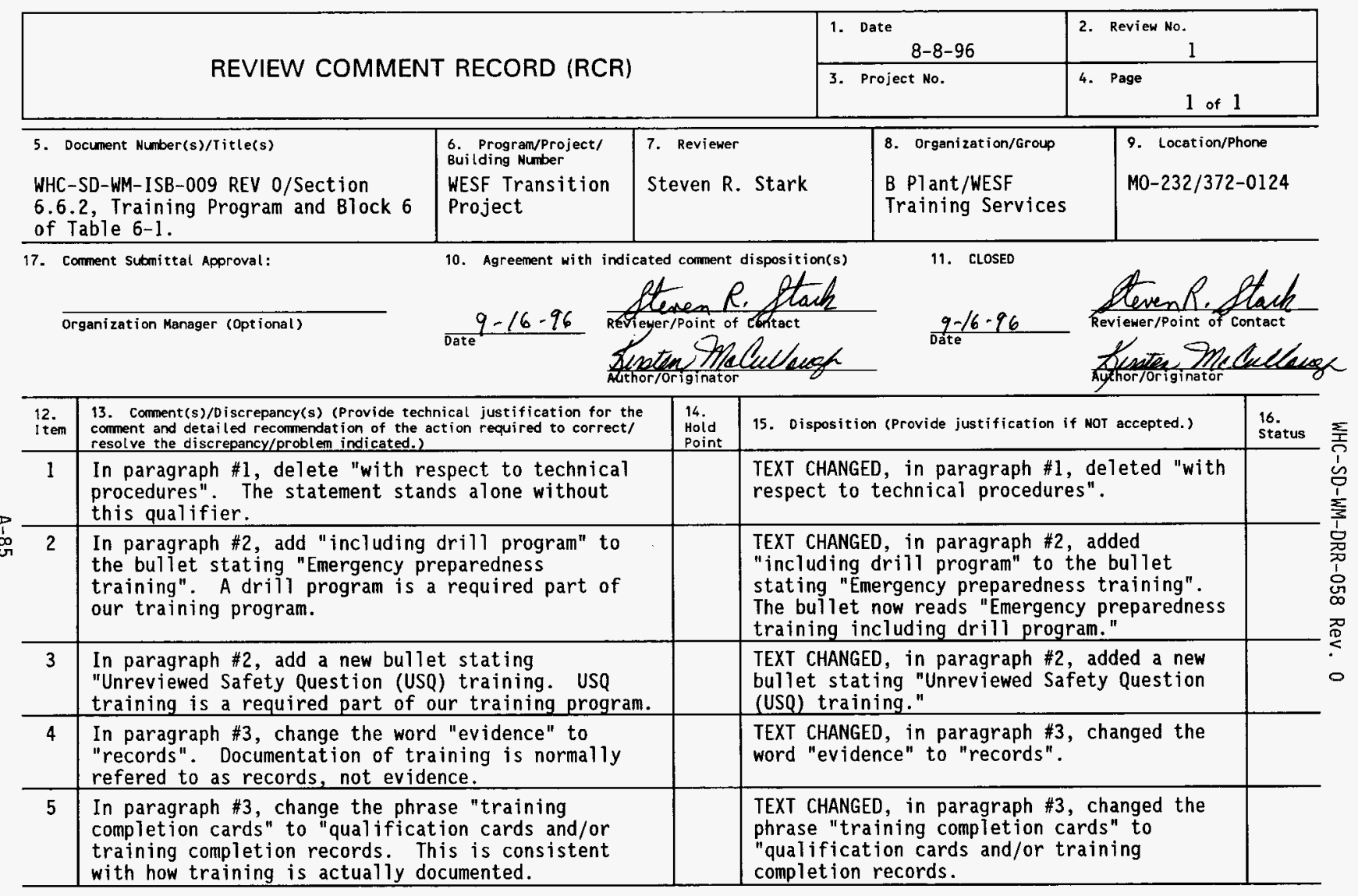




\begin{tabular}{|c|c|c|}
\hline & $\begin{array}{l}\text { 1. Date } \\
\\
\end{array}$ & $\begin{array}{r}\text { 2. Review No. } \\
1\end{array}$ \\
\hline REVIEW COMMENI RECORD (RCR) & 3. Project No. & 4. Page \\
\hline
\end{tabular}

\begin{tabular}{|c|c|c|c|c|}
\hline $\begin{array}{l}12 . \\
\text { item }\end{array}$ & $\begin{array}{l}\text { 13. Comment(s)/Discrepancy(s) (Provide technical justification for the } \\
\text { comment and detailed recommendation of the action required to correct/ } \\
\text { resolve the discrepancy/problem indicated.) }\end{array}$ & $\begin{array}{l}14 . \\
\text { Hold } \\
\text { Point }\end{array}$ & 15. Disposition (Provide justification if Nor accepted.) & $\begin{array}{l}16 . \\
\text { Status }\end{array}$ \\
\hline 6 & $\begin{array}{l}\text { In paragraph } \# 3 \text {, delete the last sentence in this } \\
\text { paragraph. There is no reason to have this } \\
\text { statement and it isn't always true. }\end{array}$ & & $\begin{array}{l}\text { TEXT CHANGED, in paragraph \#3, deleted the } \\
\text { last sentence in the paragraph. }\end{array}$ & \\
\hline 7 & $\begin{array}{l}\text { In Block } 6 \text { of Table } 6-1 \text {, Column } 2: \text { 1) Delete } \\
5480.18 \text { A and } 2 \text { ) Add } 5480.19 \text {. WESF does not fall } \\
\text { into Category A Reactors but Conduct of Operations } \\
\text { does apply to WESF Operations. }\end{array}$ & & $\begin{array}{l}\text { TEXT CHANGED, in Block } 6 \text { of Table } 6-1 \text {, } \\
\text { Column } 2: 1 \text { ) Deleted } 5480.18 \mathrm{~A} \text {. DOE } 5480.19 \text {, } \\
\text { Conduct of Operations is identified as a } \\
\text { WHC/WESF requirement in Item } \# 4 \text {. }\end{array}$ & \\
\hline 8 & $\begin{array}{l}\text { In Block } 6 \text { of Table } 6-1 \text {, Column } 3: 1 \text { ) Delete WHC-CM- } \\
2-18 \text {, 2) Add WHC-CM-5-6, Section } 8 \text {, and } 3 \text { ) Add } \\
\text { WHC-IP-1182. WHC-CM-2-18 in a TRS procedure and } \\
\text { does not apply to WESF. WHC-CM-5-6, Section } 8 \\
\text { defines the Training Program for WESF and } \\
\text { WHC-IP-1182 gives facility Specific information on } \\
\text { Conduct of Operations for WESF. }\end{array}$ & & $\begin{array}{l}\text { TEXT CHANGED, Table } 6-1 \text {, Column } 3: 1 \text { ) } \\
\text { Deleted WHC-CM-2-18, } 2 \text { ) Added WHC-CM-5-6 to } \\
\text { the second I in section } 6.0 \text { and } 3 \text { ) Added } \\
\text { WHC-IP- } 1182 \text { to the second I in section } 6.0 \text {. }\end{array}$ & \\
\hline
\end{tabular}




\section{REVIEW COMMENT RECORD (RCR)}

\begin{tabular}{|c|l|}
\hline \begin{tabular}{|l|} 
1. Date \\
$07 / 31 / 96$
\end{tabular} & 2. Review No. \\
\hline $\begin{array}{c}\text { 3. Project No. } \\
\text { ISB }\end{array}$ & 4. Page \\
\hline
\end{tabular}

5. Document Number(s)/Title(s)

WHC-SD-WM-ISB-009 REV 0 WESF Interim Safety Basis

6. Program/Project/
Building Number

10. Agreement with indicated comment disposition(s)

17. Comment Submittal Approval:

Organization Manager (Optional)

\section{$8 / 28 / 96$ \\ Date}

\begin{tabular}{|l|l}
\hline 7. Reviewer & 8. Organization/Group \\
M. Kaleem Ullah & B Plant/WESF Safety
\end{tabular}

11. CLOSED

$M$ Kaleem U1l ah Reviewer/Point of Contact

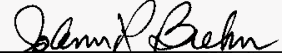

12. 13. Comment(s)/Discrepancy(s) (Provide technical justification for the Item comment and detailed recommendation of the action required to correct/ resolve the discrepancy/problem indicated.)

1. General Comment:

$\sum_{1}^{\infty}$

a) This document especially the Sections $1,2,3,5$, and 6 needs a Technical Writer's review for coherence and flow of the subject matter. As an example for this comment, see paragraphs: $1.0,1.1$, $1.7,3.3 .2 .2,3.4 .2$, page $3-36$, page $3-148$, etc.

b) Section 1.0 "Introduction and Summary" first paragraph last sentence "Interim Controlled storage of the encapsulated cesium and strontium at WESF will be necessary for a minimum of five years." Is this the current long term policy of the DOE for the WESF storage facility? If so, then why we are spending this much money to perform ISB, and not recommending cost effective measures of continued operation with the current safety documentation which have faithfully served the facility operation well in the past?
15. Disposition (Provide justification if NOT accepted.)

a) The entire document has been reviewed by a technical editor during the functional review. Changes have been made, another technical editing will take place after comments have been incorporated from the functional review.

b) The implementation plan does not quantify a time for WESF to remain operational. There have been different lengths of time suggested by many people, including DOE-RL. He do know that it will be a minimum of five years, which means an ISB needs to be prepared now per the implementation plan and a SAR needs to be prepared after the ISB per the implementation plan. The new ISB and SAR will be more cost effective and efficient for WESF use (ie. USQ determination, less OSRs etc.) There are many problems in the current SAR - mission change etc. 


\begin{tabular}{|c|l|l|}
\hline \multirow{2}{*}{ REVIEW COMMENT RECORD (RCR) } & $\begin{array}{l}\text { Date } \\
07 / 31 / 96\end{array}$ & $\begin{array}{c}\text { Review No. } \\
100\end{array}$ \\
\cline { 2 - 3 } & $\begin{array}{c}3 . \text { Project Ho. } \\
\text { ISB }\end{array}$ \\
\hline
\end{tabular}

\begin{tabular}{|c|c|c|c|c|}
\hline $\begin{array}{l}12 . \\
\text { 1 tem }\end{array}$ & $\begin{array}{l}\text { 13. Comment(s)/Discrepancy(s) (Provide technical justification for the } \\
\text { comment and detailed recommendat ion of the action required to correct/ } \\
\text { resolve the discrepancy/problem indicated.) }\end{array}$ & $\begin{array}{l}14 . \\
\text { Hoid } \\
\text { Point }\end{array}$ & 15. Disposition (Provide justification if NOT accepted.) & $\begin{array}{l}16 . \\
\text { Status }\end{array}$ \\
\hline 1. & $\begin{array}{l}\text { (Comment } 1 \text { Continued) } \\
\text { Second para starts with the statement: } \\
\text { "Existing safety documentation for WESF operation } \\
\text { is no longer in compliance with recently mandated } \\
\text { U.S. Department of Energy (DOE) safety orders." } \\
\text { Are we talking about paper compliance here or } \\
\text { hardware system compliance? If system compliance is } \\
\text { the issue, we should clarify our position in this } \\
\text { para. }\end{array}$ & & $\begin{array}{l}\text { We are probably talking both paper and } \\
\text { hardware compliance; for instance, more } \\
\text { guidance in the form of DOE standards } \\
\text { provides for detail instruction on accident } \\
\text { analysis, TSR, etc. The guidance for TSRs } \\
\text { today alieviates a lot of control details } \\
\text { now seen in the present OSRs, yet worker } \\
\text { safety is emphasized and by the new rules } \\
\text { may require a TSR not currently seen. }\end{array}$ & C \\
\hline 2. & $\begin{array}{l}\text { Section } 1.1 \text { Purpose } \\
\text { Generally under the purpose of the ISB, I am used to } \\
\text { finding such statement as, to identify the hazard, } \\
\text { and risks to workers, environment, and public, and } \\
\text { perform risk and design basis accident analysis, and } \\
\text { then recommend controls. None of these familiar } \\
\text { statements appear in the section. What I read in } \\
\text { this paragraph is a paper compliance to new mandated } \\
\text { orders etc. }\end{array}$ & & $\begin{array}{l}\text { TEXT CHANGE - The following paragraph has } \\
\text { been added to Section } 1.0 \text {, "The new safety } \\
\text { documentation identifies hazards associated } \\
\text { with the current capsule storage mission and } \\
\text { quantitatively analyzed those hazards with } \\
\text { the potential for exceeding predetermined } \\
\text { dose consequences for the non-WESF facility } \\
\text { worker and the public. In addition, } \\
\text { accident consequences to the environment and } \\
\text { the WESF facility worker are identified. } \\
\text { Administrative and engineered controls are } \\
\text { used to prevent or mitigate the risk } \\
\text { associated with the hazards to the facility } \\
\text { and non-WESF worker, the public, and the } \\
\text { environment." }\end{array}$ & C \\
\hline
\end{tabular}




\begin{tabular}{|l|l|l|}
\hline \multirow{2}{*}{ REVIEW COMMENT RECORD (RCR) } & $\begin{array}{l}\text { 1. Date } 07 / 31 / 96 \\
\text { 2. Review No. } \\
100\end{array}$ \\
\cline { 2 - 3 } & $\begin{array}{l}\text { 3. Project No. } \\
\text { ISB }\end{array}$ & $\begin{array}{l}\text { 4. Page } \\
3 \text { of } 9\end{array}$ \\
\hline
\end{tabular}

12. 13. Comment(s)/Discrepancy(s) (Provide technical justification for the 12. 13. Comment(s)/D iscrepancy(s) (Provide technical justification for the
Item comment and detailed recommendation of the action required to correct/ resolve the discrepancy/problem indicated,)

3. Table 1-1, Page 1-6, third column vs Natural Phen. a) How does the item 7 , which is nothing but study to evaluate $\mathrm{K}-3$ filter box will mitigate the consequences for which credit is being taken? I suggest that items for which credit is taken for mitigation should be isolated from the future commitment.

Same Table Page 1-7

b) regarding the Truckport Fire, an IOSR is recommended for inventory controls. Truckport area does have some combustibles plastic bags in boxes. If we remove those boxes, we will reduce the inventory; hence this IOSR could be completely taken out this ISB. Please look into this if this is possible to remove these bags and have no ISOR item.

4. Section 1.7 Conclusion

Please see the last two sentences which can be rephrased.

I suggest to delete the words "based on ............ in Table 1-1." These words are a repeat in this section. Deletion will not distort the meaning we want to convey. The two exceptions which exceed the risk EGs should provide a reference to the relevant sections of the chapter 3 or chapter 6 .

TEXT CHANGE - Deleted "based on.... in Table 1-1." Revised to, "These two exceptions (see Sections 3.4.2.1 and 3.4.2.3), ..."
16. 14.
Hold Hold
Point

15. Disposition (Provide justification if NOT accepted.) Status

a) Item 7 deleted.

b) If the combustibles are removed, the consequences will be lower. WESF will pursue this activity. Upon completion, a USQ determination can be processed with a resulting change in the ISB and IOSR. 


\begin{tabular}{|l|l|l|}
\hline \multirow{2}{*}{ REVIEW COMMENT RECORD (RCR) } & $\begin{array}{l}\text { 1. Date } \\
07 / 31 / 96\end{array}$ & $\begin{array}{c}2 . \quad \text { Review Ho. } \\
100\end{array}$ \\
\cline { 2 - 4 } & $\begin{array}{c}3 . \text { Project No. } \\
\text { ISB }\end{array}$ & $\begin{array}{c}4 . \text { Page } \\
4 \text { of } 9\end{array}$ \\
\hline
\end{tabular}

12. 13. Comment(s)/0 iscrepancy(s) (Provide technical justification for the

I ter coment and detailed recontendation of the action required to correct/ resolve the discrepancy/problem indicated.)

\section{4.}

Page 1-9, last paragraph.

"It is concluded that WESF can continue to operate, ......" Additionally, ......Table 1-1, that will enhance the safety Jayers.... and administrative controls that have resulted from the ISB process."

Several questions: Is safety enhancement mandatory with additional administrative controls? What are the consequences if we do not adopt these additional administrative controls? If your answer is no, then it contradicts with what the first sentence says. I suggest that if the first sentence is modified to include that, "With the controls recommended in the Section 6.0 , it is concluded that WESF can continue to operate........". I hope I made my point clear, that connotations and the meaning conveyed from the word "Additionally", after the first sentence, are entirely wrong to the reader of this document. Please rephrase.

\begin{tabular}{l|l|l}
\hline 6. & $\begin{array}{l}\text { Section } 2.0 \\
\text { I have no comment on this section. }\end{array}$ & No response required. \\
\hline 7. & $\begin{array}{l}\text { Section } 3.1, \text { Page 3-2 } \\
\text { First para at the top of page. } \\
\text { I suggest that activities not allowable should be } \\
\text { reiterated in Section } 6 \text { as we11. }\end{array}$ & $\begin{array}{l}\text { Chapter } 6 \text { has been drafted to follow the } \\
\text { outline provided in D0E-STD-3009-94. This } \\
\text { DoE standard does not require that Chapter } 6 \\
\text { discuss activities not allowed to be } \\
\text { conducted in the facility. Chapters } 1 \text { and } 2 \\
\text { list activities not allowed within the scope } \\
\text { of this ISB. }\end{array}$ \\
\hline
\end{tabular}

TEXT CHANGE - The first sentence to the last paragraph has been revised to, "With the controls identified in Chapters 3.0 and 6.0 of this BIO, and the IOSRs, it is concluded that WESF...." The remainder of the paragraph has been deleted.
16. Status 


\begin{tabular}{|c|c|c|}
\hline & $\begin{array}{l}\text { 1. Date } \\
\qquad 07 / 31 / 96\end{array}$ & $\begin{array}{r}\text { 2. Review No. } \\
100\end{array}$ \\
\hline REVIEW COMMENT RECORD (RCR) & $\begin{array}{l}\text { 3. Project No. } \\
\text { ISB }\end{array}$ & $\begin{array}{l}\text { 4. Page } 5 \text { of } 9 \\
\end{array}$ \\
\hline
\end{tabular}

\begin{tabular}{|c|c|c|c|c|}
\hline $\begin{array}{l}12 . \\
\text { I tem }\end{array}$ & $\begin{array}{l}\text { 13. Comment(s)/Discrepancy(s) (Provide technical justification for the } \\
\text { comment and detai led recommendation of the action required to correct/ } \\
\text { resolve the discrepancy/problem indicated.) }\end{array}$ & $\begin{array}{l}14 . \mathrm{id} \\
\text { Hoid } \\
\text { Point }\end{array}$ & 15. Disposition (Provide justification if nor accepted.) & $\begin{array}{l}16 . \\
\text { status }\end{array}$ \\
\hline 8. & $\begin{array}{l}\text { Page 3-12, below the Table middle para. } \\
\text { We have no analysis to base our judgement on the } \\
\text { events that happened in Decatur Facility. Any } \\
\text { conclusions are inferences and are not applicable to } \\
\text { WESF facility. I suggest that it should be rephrased } \\
\text { to separate the upset experience at WESF and the } \\
\text { experience at Decatur Facility. }\end{array}$ & & $\begin{array}{l}\text { TEXT CHANGE - This paragraph has been split } \\
\text { into two paragraphs and each one totally } \\
\text { rewritten based on your comments. }\end{array}$ & C \\
\hline 9. & $\begin{array}{l}\text { Page } 3-13 \text {, Section } 3.3 .2 .2 \text {, Hazard Classification } \\
\text { Second sentence states " the prel iminary hazard } \\
\text { category assigned to WESF is Hazard Category } 2 \ldots " \\
\text { In the middle statements like "DOE reserves the } \\
\text { right to designate ...Category 1." Then you talk } \\
\text { about "unmitigated Hazard Category". In closing this } \\
\text { paragraph, "If, as ......... then the facility is } \\
\text { designated a category I hazard." I am not clear what } \\
\text { message is being conveyed here. DOE should know } \\
\text { whether to assign this facility a Hazard Category } 2 \\
\text { or l. DOE is informed of our analysis in 1994. I } \\
\text { suggest deletion statements from line } 28 \text { to line } 38 \text {. }\end{array}$ & & $\begin{array}{l}\text { The hazard categorization being presented to } \\
\text { DOE in the ISB is the final categorization, } \\
\text { as opposed to the preliminary categorization } \\
\text { presented in } 1994 \text {. The ISB categorization } \\
\text { contains much more information than the } 1994 \\
\text { categorization by analyzing the worst-case } \\
\text { consequences. This provides the DOE with } \\
\text { all of the information they may need to } \\
\text { decide if WESF needs to be a category } 1 \text {. } \\
\text { Therefore, it is desired to make it very } \\
\text { clear that DOE must make their decision now, } \\
\text { because no new information will be added in } \\
\text { the future. }\end{array}$ & C \\
\hline 10 . & $\begin{array}{l}\text { Page 3-14, Third para from top of page. } \\
\text { "The WESF facility consists of three seismically } \\
\text { independent structures." No mention of those areas } \\
\text { is made in the following sentences in this } \\
\text { paragraph. I suggest those three areas should be } \\
\text { identified in this para. }\end{array}$ & & $\begin{array}{l}\text { TEXT CHANGE - Text added "Area } 1 \text { is the } \\
\text { office and Support Area, Area } 2 \text { is the Hot } \\
\text { Cel1 Area, and Area } 3 \text { is the Pool Cell } \\
\text { Area." }\end{array}$ & $\mathrm{C}$ \\
\hline
\end{tabular}




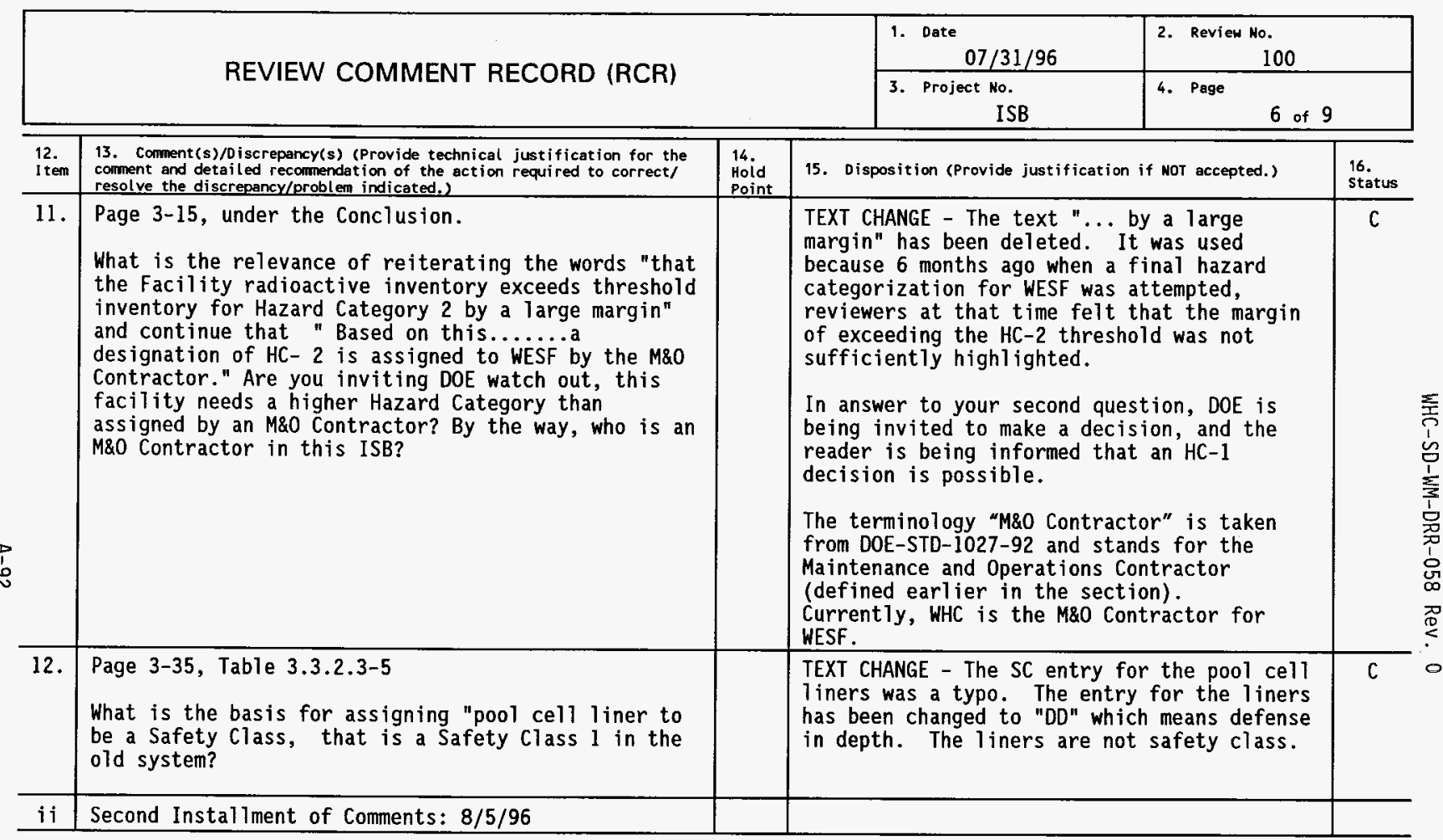




\begin{tabular}{|c|l|l|}
\hline \multirow{2}{*}{ REVIEW COMMENT RECORD (RCR) } & $\begin{array}{c}\text { 1. Date } \\
07 / 31 / 96\end{array}$ & $\begin{array}{c}\text { Review No. } \\
100\end{array}$ \\
\cline { 2 - 3 } & $\begin{array}{c}3 . \text { Project Ho. } \\
\text { ISB }\end{array}$ & $\begin{array}{c}4 . \text { Page } \\
7 \text { of } 9\end{array}$ \\
\hline
\end{tabular}

\begin{tabular}{|c|c|c|c|c|}
\hline $\begin{array}{l}12 . \\
\text { It }\end{array}$ & $\begin{array}{l}\text { 13. Comment(s)/D iscrepancy(s) (Provide technical justification for the } \\
\text { comment and detai led recomnendation of the action requi red to correct/ } \\
\text { resolve the discrepancy/problem indicated.) }\end{array}$ & $\begin{array}{l}14 . \\
\text { Hoid } \\
\text { Point }\end{array}$ & 15. Disposition (Provide justification if NOT accepted.) & $\begin{array}{l}16 . \\
\text { Status }\end{array}$ \\
\hline 13. & $\begin{array}{l}\text { Page 3-95, top two paragraphs } \\
\text { Use of Steam Jets, both the basis and justification } \\
\text { for obtaining additional exhaust during the failure } \\
\text { of } k-3 \text { exhaust redundant fans should be presented. I } \\
\text { used to think that a study was performed and it } \\
\text { recommended that Steam Jets be eliminated. I hope } \\
\text { this study is available to the ISB writers. }\end{array}$ & & $\begin{array}{l}\text { The K-3 steam jets are credited for the } \\
\text { following: as a defense in depth feature to } \\
\text { provide ventilation flow. The K-3 jet is } \\
\text { not credited for anything else. }\end{array}$ & C \\
\hline 14. & $\begin{array}{l}\text { Page 3-95, Major Assumptions: } \\
\text { Continued to Page } 3-99: \\
\text { What mitigating credits are being taken for the use } \\
\text { of Steam Jets? and What DBA requirements are to be } \\
\text { satisfied by the Steam Jets? } \\
\text { Considering the Loss of K-3 Ventilation (3.4.2.4.2), } \\
\text { no release to outside is to occur. Also migration } \\
\text { consequences within the facility were found to be } \\
\text { very low. I presume that Loss of K-3 was considered } \\
\text { with no availability of Steam Jets, this means Steam } \\
\text { Jets are not credited as mitigating factors? }\end{array}$ & & $\begin{array}{l}\text { The K-3 steam jets are credited for the } \\
\text { following: as a defense in depth feature to } \\
\text { provide ventilation flow. The } \mathrm{K}-3 \text { jet is } \\
\text { not credited for anything else. }\end{array}$ & C \\
\hline 15. & $\begin{array}{l}\text { Page 3-148 Pool Cell Drain Line Failure? } \\
\text { Are we taking credit for Steam Jets for the Drain } \\
\text { Line Failure consequences analysis? }\end{array}$ & & $\begin{array}{l}\text { The drain line jet pump is not credited in } \\
\text { the accident analysis. This jet is } \\
\text { mentioned as part of the description of the } \\
\text { system and could not prevent or mitigate the } \\
\text { consequences of the accident. }\end{array}$ & C \\
\hline 16. & $\begin{array}{l}\text { Page 3-152, 3rd Para from the top of page: } \\
\text { Assumption that } 0.1 \mathrm{Kg} \text { of } \mathrm{CsCl} \text { salt is released from } \\
\text { the failed capsule is not clear to me. Please } \\
\text { clarify? }\end{array}$ & & $\begin{array}{l}\text { This is not an assumed value, but one } \\
\text { determined from the thermal and capsule } \\
\text { failure models in the referenced document } \\
\text { (Hey 1996). It is the average salt mass } \\
\text { which must be released to relieve capsule } \\
\text { stresses. It is conservative in that } \\
\text { capsule yield is not credited. }\end{array}$ & $\mathrm{C}$ \\
\hline
\end{tabular}




\begin{tabular}{|c|l|l|}
\hline \multirow{2}{*}{ REVIEW COMMENT RECORD (RCR) } & $\begin{array}{c}\text { Date } \\
07 / 31 / 96\end{array}$ & $\begin{array}{c}2 . \quad \text { Review No. } \\
100\end{array}$ \\
\cline { 2 - 4 } & $\begin{array}{c}3 . \text { Project No. } \\
\text { ISB }\end{array}$ & $\begin{array}{c}4 . \text { Page } \\
8 \text { of } 9\end{array}$ \\
\hline
\end{tabular}

\begin{tabular}{|c|c|c|c|c|}
\hline $\begin{array}{l}12 . \\
\text { item }\end{array}$ & $\begin{array}{l}\text { 13. Comment(s)/Discrepancy(s) (Provide technical justificat ion for the } \\
\text { comment and detailed recommendation of the action requi red to correct/ } \\
\text { resolve the discrepancy/problem indicated.) }\end{array}$ & $\begin{array}{l}14 . \\
\text { Hold } \\
\text { Point }\end{array}$ & 15. Disposition (Provide justification if NOT accepted.) & $\begin{array}{l}16 . \\
\text { status }\end{array}$ \\
\hline 17. & $\begin{array}{l}\text { Page } 3-154, \text { Paragraph just above the last para on } \\
\text { this page. } \\
\text { "The Dose at the alternate site boundary described } \\
\text { in Section } 3.4 .1 .2 \text {, would be .....3.1x10 to }-4 \text { rem } \\
\ldots \text { ". cannot be found as referenced? }\end{array}$ & & $\begin{array}{l}\text { Wrong section is referenced. The correct } \\
\text { section is } 3.4 .1 .3 \text { which does describe the } \\
\text { alternate site boundary considered, as well } \\
\text { as the ramifications to the dose } \\
\text { calculations. }\end{array}$ & C \\
\hline 18. & $\begin{array}{l}\text { Page 3-156, Section 3.4.2.7.2.1, Describes three } \\
\text { potential causes for the loss of water from all pool } \\
\text { cells, and one of the causes is a "loss of water in } \\
\text { a single capsule storage pool". How this could be a } \\
\text { cause of loss of water from all pool cells? }\end{array}$ & & $\begin{array}{l}\text { TEXT CHANGE - Unfortunately, the link } \\
\text { between a loss of water from a single pool } \\
\text { and all pools required some evolution to } \\
\text { develop. Documentation has not kept up. A } \\
\text { discussion has now been incorporated to } \\
\text { explain this connection. It goes something } \\
\text { like this: } \\
\text { The loss of water from a single pool cell } \\
\text { creates fatal dose fields within the pool } \\
\text { cell area and a field of approximately } 120 \\
\text { R/hr immediately outside the 225-B } \\
\text { structure. Dose fields in the operating } \\
\text { gallery have not been calculated, but are } \\
\text { presumed to prevent continued habitation. } \\
\text { Currently there is no control which could be } \\
\text { relied upon to terminate this event. The } \\
\text { event progression leads to gradual } \\
\text { evaporative loss of water in the remaining } \\
\text { pool cells and thermally induced failure of } \\
\text { uncovered capsules. The event is bounded by } \\
\text { the consequences estimated for a loss of } \\
\text { water in all pool cells. }\end{array}$ & C \\
\hline
\end{tabular}




\begin{tabular}{|c|l|l|}
\hline \multirow{2}{*}{ REVIEW COMMENT RECORD (RCR) } & $\begin{array}{c}\text { 1. Date } \\
07 / 31 / 96\end{array}$ & $\begin{array}{c}2 . \text { Review No. } \\
100\end{array}$ \\
\cline { 2 - 4 } & $\begin{array}{c}\text { 3. Project No. } \\
\text { ISB }\end{array}$ & $\begin{array}{l}4 . \text { Page } \\
9\end{array}$ \\
\hline
\end{tabular}

\begin{tabular}{|c|c|c|c|c|}
\hline $\begin{array}{l}12 . \\
1 \text { tem }\end{array}$ & $\begin{array}{l}\text { 13. Comment(s)/Discrepancy(s) (Provide technical justification for the } \\
\text { corment and detailed recommendation of the action required to correct/ } \\
\text { resolve the discrepancy/problem indicated.) }\end{array}$ & $\begin{array}{l}14 . \\
\text { Hold } \\
\text { Point }\end{array}$ & 15. Disposition (Provide justification if NOT accepted.) & $\begin{array}{l}16 . \\
\text { Status }\end{array}$ \\
\hline 19. & $\begin{array}{l}\text { Page 6-1, } \\
\text { I would recommend the following to be included in } \\
\text { the list of Safety programs: } \\
\text { Industrial Hygiene, WHC-CM-1-11 } \\
\text { Industrial Safety, WHC-CM-1-10 }\end{array}$ & & $\begin{array}{l}\text { Please see Table } 6-1 \text {, beginning page } 6-2 \text {. } \\
\text { The Table identifies requirements that WESF } \\
\text { must meet. } \\
\text { (1) No text change. Industrial Hygiene, } \\
\text { WHC-CM-1-11 is identified in Table 6-1, } \\
\text { under item 2. Hazardous Material } \\
\text { Protection. } \\
\text { (2) No text change. Industrial Safety, WHC- } \\
\text { CM-1-10, Safety Manual is identified in } \\
\text { Table 6-1 under item 4. Operational Safety }\end{array}$ & C. \\
\hline 20. & $\begin{array}{l}\text { Page } 6-3 \text {, refers to WHC-CM-4-9, Radiological Design } \\
\text { which was deleted sometime ago. }\end{array}$ & & $\begin{array}{l}\text { TEXT CHANGE - WHC-CM-4-9, Radiological } \\
\text { Design is deleted from Table } 6-1 \text {, item } 3 \text {. } \\
\text { Radiological and Hazardous Waste Management }\end{array}$ & C \\
\hline 21. & $\begin{array}{l}\text { Page } 6-5 \text {, refers to WHC-CM-4-6, Compliance } \\
\text { Assurance, which was deleted? }\end{array}$ & & $\begin{array}{l}\text { TEXT CHANGE - WHC-CM-4-6, Compliance } \\
\text { Assurance is deleted from Table } 6-1 \text {, item } 9 . \\
\text { Management Organization and Institutional } \\
\text { Safety Provisions. }\end{array}$ & C \\
\hline 22. & $\begin{array}{l}\text { Section } 4.0 \\
\text { No comments. }\end{array}$ & & No response required. & C \\
\hline 23. & $\begin{array}{l}\text { Section } 5.0 \\
\text { No comments. }\end{array}$ & & No response required. & C \\
\hline
\end{tabular}


WHC-SD-WM-DRR-058 Rev. 0

This page intentionally left blank. 


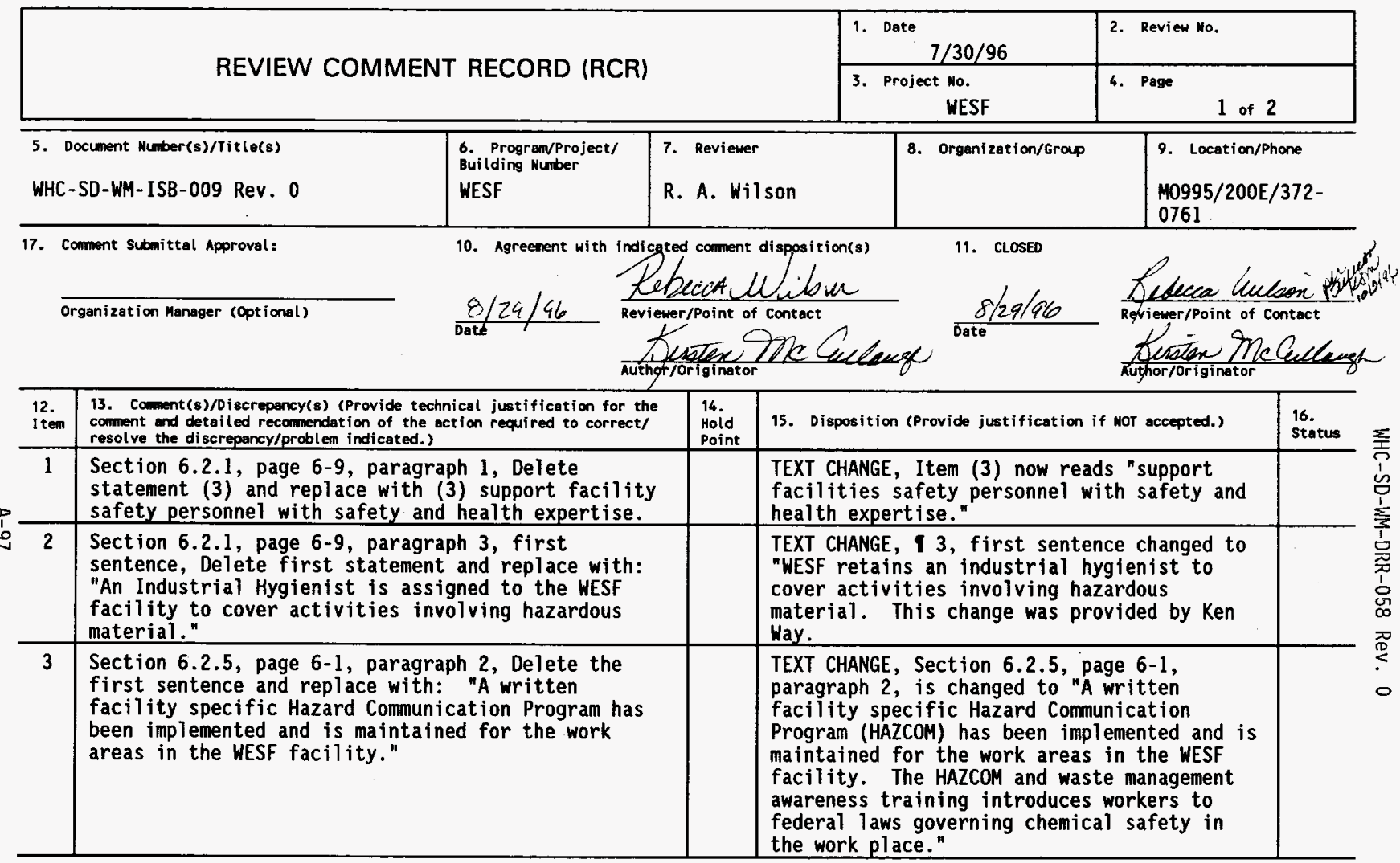




\begin{tabular}{|c|c|c|}
\hline & $\begin{array}{r}\text { 1. Date } \\
\\
7 / 30 / 96 \\
\end{array}$ & 2. Review No. \\
\hline REVIEVV CUIVIVIEIVI RELURD (RCK) & $\begin{array}{l}\text { 3. Project No. } \\
\text { WESF }\end{array}$ & $\begin{array}{l}\text { 4. Page } 2 \text { of } 2 \\
\text { L } 2\end{array}$ \\
\hline
\end{tabular}

\begin{tabular}{|c|c|c|c|c|}
\hline $\begin{array}{l}12 . \\
\text { I tem }\end{array}$ & $\begin{array}{l}\text { 13. Conment(s)/Discrepancy(s) (Provide technical justification for the } \\
\text { comment and detailed recommendation of the action required to correct/ } \\
\text { resolve the discrepancy/probtem indicated.) }\end{array}$ & $\begin{array}{l}14 . \\
\text { Hold } \\
\text { Point }\end{array}$ & 15. Disposition (Provide justification if NOT accepted.) & $\begin{array}{l}16 . \\
\text { Status }\end{array}$ \\
\hline 4 & $\begin{array}{l}\text { Section } 6.2 .6 \text {, page } 6-10 \text {, This section does not } \\
\text { apply to the WESF facility. WESF has no chemicals } \\
\text { which fall under 29CFR1910.119, "Process Safety } \\
\text { Management of Highly Hazardous Chemicals." A HASP } \\
\text { has not been developed for WESF. This section can } \\
\text { be deleted or revised to indicate that 29CFR1910.119 } \\
\text { is not applicable to WESF. }\end{array}$ & & $\begin{array}{l}\text { The WESF organization has committed to } \\
\text { completing a HASP in the future. The } \\
\text { paragraph will be changed based on a redl ine } \\
\text { from Ken Way. The I. sentence } 1 \text { TEXT will } \\
\text { be CHANGED to "Requirements pertaining to } \\
\text { occupational exposure to chemicals are } \\
\text { addressed in the WHC controlled manuals (see } \\
\text { Table } 6-1 \text { ) and the American Conference of } \\
\text { Governmental Industrial Hygienists Threshold } \\
\text { Limit Values (ACGIH-TLVs). "The CFR call } \\
\text { outs have been deleted and a call out of the } \\
\text { WESF SRIDS is provided in } 6.0 \text {. The SRIDs } \\
\text { document identifies all the required CFRs to } \\
\text { be met by the WESF. }\end{array}$ & \\
\hline 5 & $\begin{array}{l}\text { Section 6.9.1, page 6-22, paragraph, "Safety/Quality } \\
\text { and Radiological Control Services", last sentence in } \\
\text { first paragraph - Change the last sentence to: "The } \\
\text { Industrial Safety and Fire Protection department } \\
\text { provides assistance with industrial safety and fire } \\
\text { protection issues. }\end{array}$ & & $\begin{array}{l}\text { TEXT CHANGE This paragraph has been deleted } \\
\text { per KAJ Mills RCR. }\end{array}$ & \\
\hline 6 & $\begin{array}{l}\text { Section 6.9.1, page 6-22, 3rd paragraph in "Safety } \\
\text { /Quality and Radiological Control Services" - Change } \\
\text { the sentence to: "Industrial Hygiene support is } \\
\text { provided by a facility "aligned" Industrial } \\
\text { Hygienist. }\end{array}$ & & $\begin{array}{l}\text { TEXT CHANGE Section } 6.9 .1 \text {, page } 6-22,3 \text { rd } \\
\text { paragraph in "Safety /Quality and } \\
\text { Radiological Control Services" - sentence is } \\
\text { changed to: "Industrial hygiene support is } \\
\text { provided by a facility aligned Industrial } \\
\text { Hygienist." }\end{array}$ & \\
\hline
\end{tabular}




\begin{tabular}{|c|l|l|}
\hline \multirow{2}{*}{ REVIEW COMMENT RECORD (RCR) } & \begin{tabular}{l} 
1. Date Review No. \\
\cline { 2 - 4 }
\end{tabular} & $\begin{array}{c}7 / 30 / 96 \\
\text { 3. Project No. } \\
\text { WESF }\end{array}$ \\
\hline
\end{tabular}

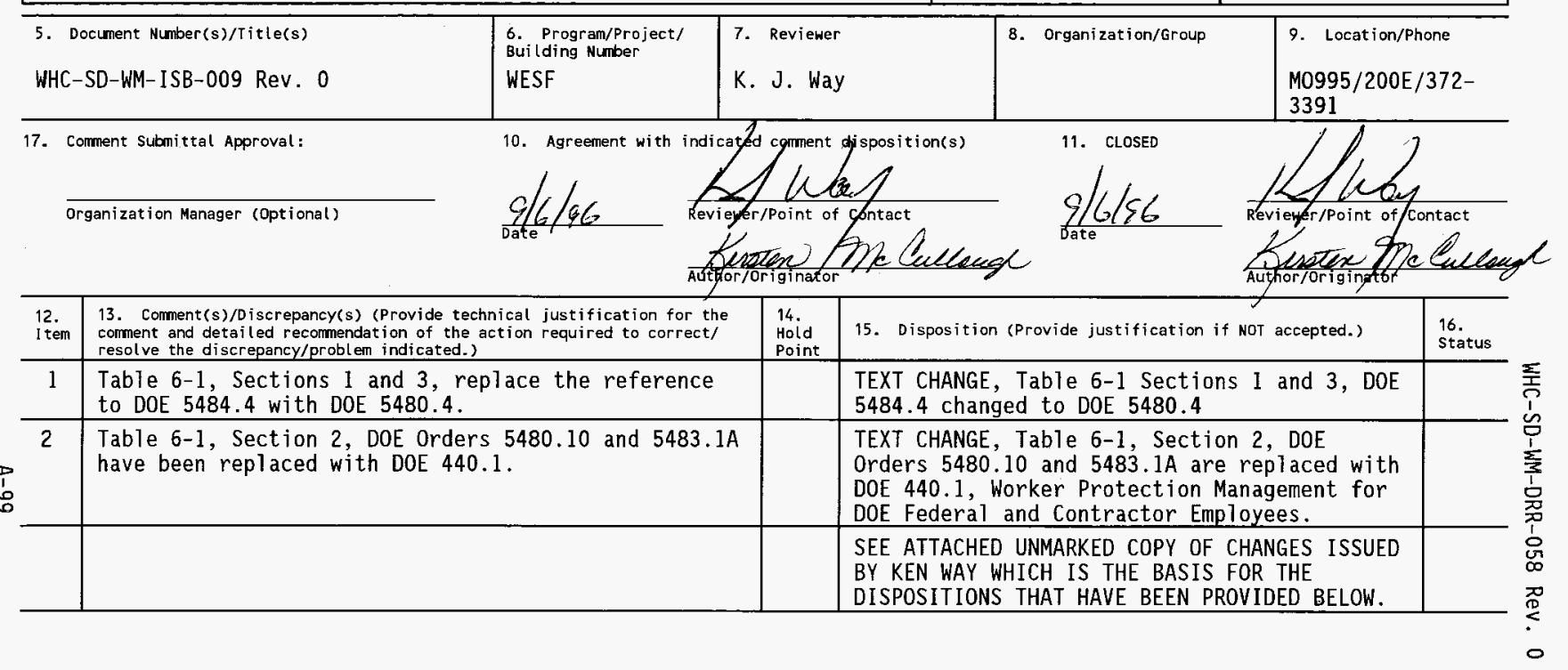




\begin{tabular}{|l|l|l|}
\hline \multirow{2}{*}{ REVIEW COMMENT RECORD (RCR) } & $\begin{array}{l}\text { Date } \\
\text { Review No. }\end{array}$ \\
\cline { 2 - 3 } & $\begin{array}{r}3 . \text { Project No. } \\
\text { WESF }\end{array}$ & $\begin{array}{l}4 . \text { Page } \\
2 \text { of } 9\end{array}$ \\
\hline
\end{tabular}

\begin{tabular}{|c|c|c|c|c|}
\hline $\begin{array}{l}12 . \\
\text { Item }\end{array}$ & $\begin{array}{l}\text { 13. Comment(s)/Discrepancy(s) (Provide technical justification for the } \\
\text { comment and detai led recormendation of the action required to correct/ } \\
\text { resolve the discrepancy/problem indicated.) }\end{array}$ & $\begin{array}{l}14 . \\
\text { Hold } \\
\text { Point }\end{array}$ & 15. Disposition (Provide justification if NOT accepted.) & $\begin{array}{l}16 . \\
\text { Status }\end{array}$ \\
\hline 3 & $\begin{array}{l}\text { Section } 6.2 .1 \text {, The majority of the section is } \\
\text { incorrect. Section needs extensive revisions. } \\
\text { Contact B Plant/WESF Industrial Hygienist for } \\
\text { specific recommended changes. }\end{array}$ & & $\begin{array}{l}6.0 \text { I } 1 \text {, sentence \#2, changed to Hazardous } \\
\text { material ..... is "obtained through } \\
\text { implementation of site and facility } \\
\text { specific" industrial hygiene...... programs, } \\
\text { "by WESF industrial Health and safety } \\
\text { personnel." } \\
6.2 .1 \text {, I 1, sentence \#2, the word "Team." } \\
\text { is deleted. Sentence \#2 item (3) is changed } \\
\text { to read "Industrial Hygiene Programs also } \\
\text { monitors hazardous material and fire safety } \\
\text { conditions across the Hanford Site and } \\
\text { functions as an information sharing resource } \\
\text { for the site. The industrial Hygiene } \\
\text { Programs Team is responsible for } \\
\text { administering the company wide industrial } \\
\text { hygiene program." } \\
\text { Create a new I with item (3) beginning with } \\
\text { a ....health and safety responsibilities. } \\
\text { Add "WESF Industrial Hygiene } \\
\text { responsibilities" in front of that part of } \\
\text { the sentence that states... relevant to } \\
\text { hazardous materials........ After (under } \\
\text { emergency conditions); delete the remainder } \\
\text { and replace it with "and facility program } \\
\text { implementation/administration." } \\
\text { Change I } 3 \text { as follows: Sentence \#l delete } \\
\text { the following part of the sentence: A } \\
\text { Hanford Site safety and health } \\
\text { representative is assigned to the WESF } \\
\text { team..... and replace with "WESF retains an } \\
\text { industrial hygienist." }\end{array}$ & \\
\hline
\end{tabular}




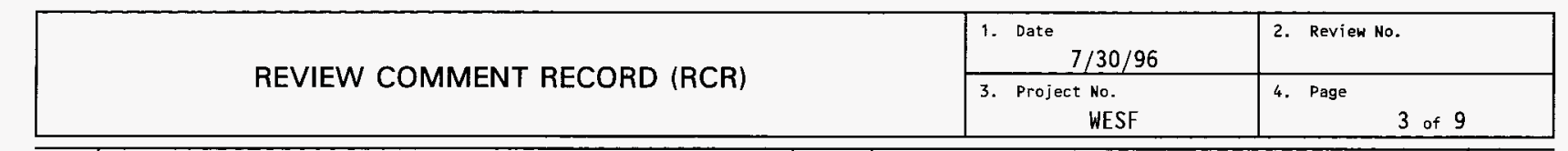

\begin{tabular}{|c|c|c|c|c|}
\hline $\begin{array}{l}12 . \\
\text { Item }\end{array}$ & $\begin{array}{l}\text { 13. Comment(s)/Discrepancy(s) (Provide technical justification for the } \\
\text { comment and detailed recommendation of the action required to correct/ } \\
\text { resolve the discrepancy/problem indicated.) }\end{array}$ & $\begin{array}{l}14 . \\
\text { Hold } \\
\text { Point }\end{array}$ & 15. Disposition (Provide justification if NOT accepted.) & $\begin{array}{l}16 . \\
\text { Status }\end{array}$ \\
\hline & & & $\begin{array}{l}\text { RCR \#3 cont. } \\
\text { Change I } 3 \text {, sentence \#2 as follows: delete } \\
\text { the word and after...facility hazards; and } \\
\text { add the following to the end of the } \\
\text { sentence, and ensuring that areas with such } \\
\text { hazards are properly posted and that access } \\
\text { is controlled properly. } \\
\text { Move } 93 \text { to the position of } ₫ 2 \text { in this } \\
\text { section. }\end{array}$ & \\
\hline 4 & $\begin{array}{l}\text { Section } 6.2 .4 \text {, It is unclear what this section } \\
\text { pertains to, needs rewording and clarification. } \\
\text { Contact WESF IH for changes. }\end{array}$ & & $\begin{array}{l}\text { This information is required by Standard } \\
3009 \text { and covers instrumentation for chemical } \\
\text { and/or radiological monitoring. No change to } \\
6.2 .4 \text { provided in write up. }\end{array}$ & \\
\hline
\end{tabular}




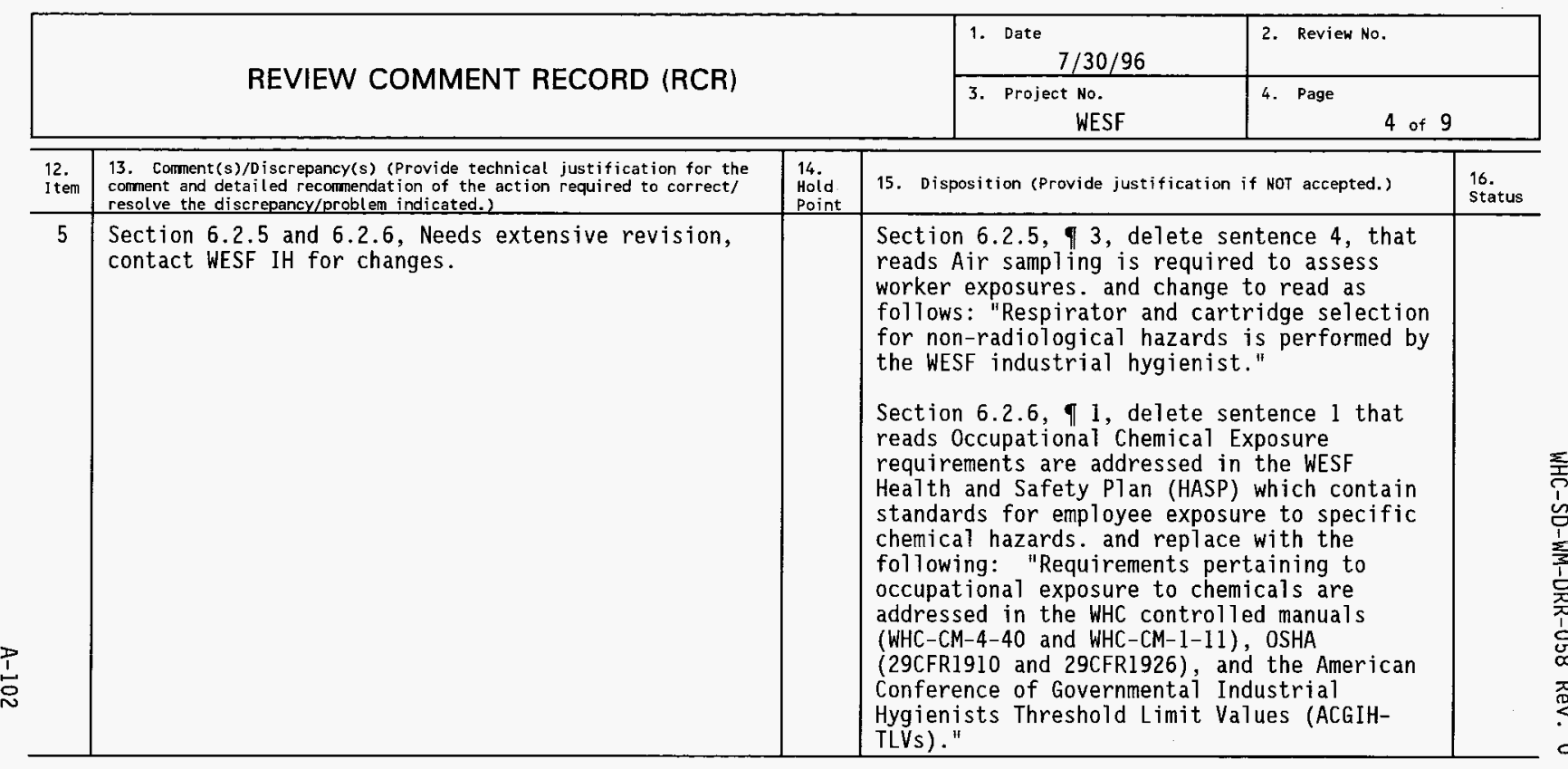




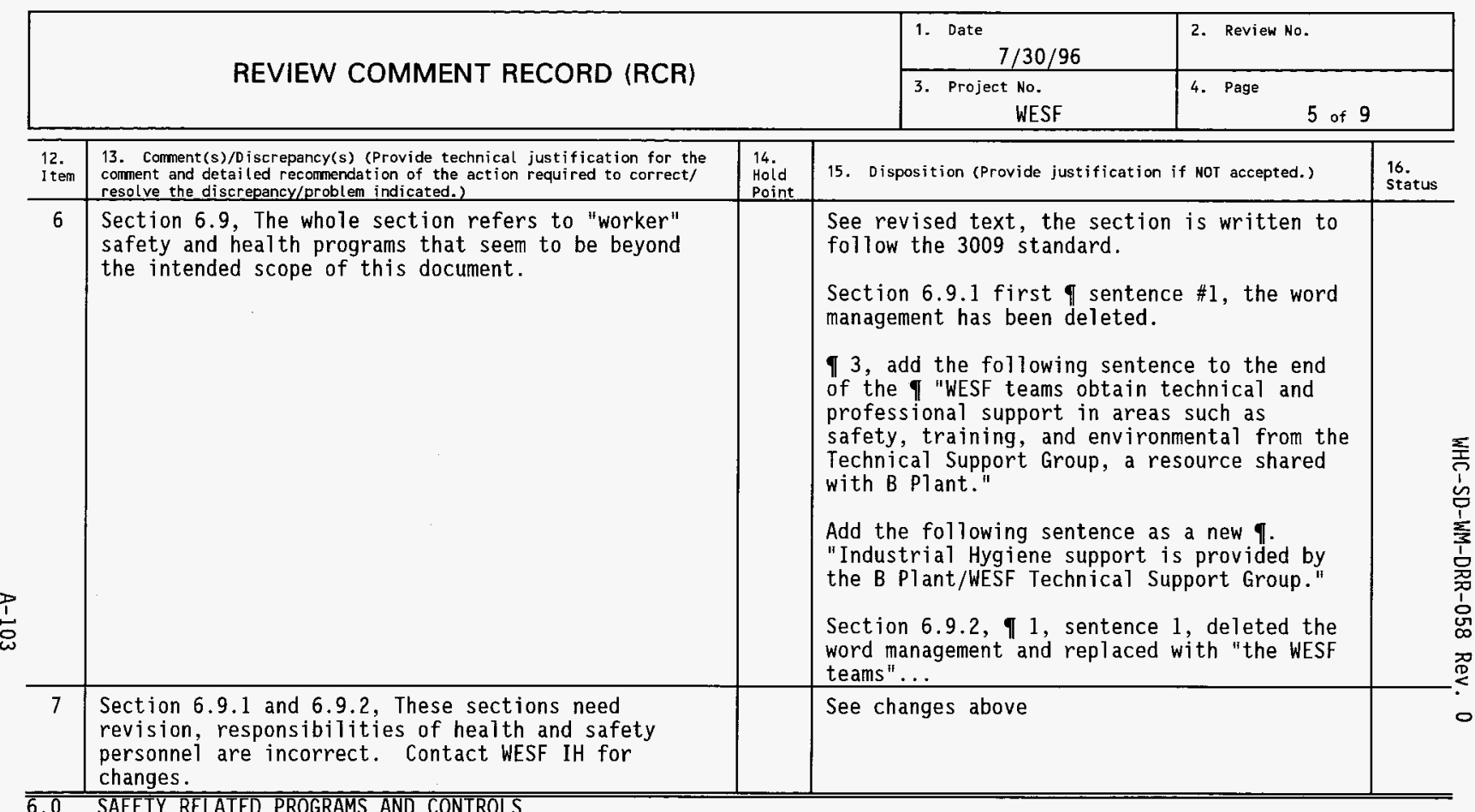

\section{HAZARDOUS MATERIAL PROTECTION (Sig...wording revisions..kjw)}

This section describes the essential elements of the Hazardous Material Protection program as it relates to the operation of WESF. Hazardous material protection for WESF is obtained through implementation of site and facility specific industrial hygiene and industrial safety programs by WESF industrial health and safety personnel. The goal is to protect workers and the environment from exposure to hazardous materials. 


\begin{tabular}{|c|c|c|}
\hline \multirow{2}{*}{ REVIEW COMMENT RECORD (RCR) } & $\begin{array}{l}\text { 1. Date } \\
7 / 30 / 96 \\
\end{array}$ & 2. Review No. \\
\hline & $\begin{array}{l}\text { 3. Project No. } \\
\text { WESF }\end{array}$ & 4. Page \\
\hline
\end{tabular}

Hazardous substances or materials referred to in this section are those nonradioactive materials that pose a hazard to workers or to the public because of their chemical or physical properties. The hazardous materials at WESF are identified in Table 3.3.2.1-1.

Hazardous Material Protection and Orqanization Sig..extensive rewording, nearly the whole of the section was modified. .kjw)

The Safety/Quality and Radiation Protection Program is responsible for the sitewide hazardous materials safety program. Industrial Hygiene Programs within the department is chartered to (1) develop industrial health and safety programs and requirements, (2) perform independent reviews of activities and documents having potential industrial safety or hygiene implications, and (3) support facilities with safety and health expertise. Industrial Hygiene Programs also monitors hazardous material and fire safety conditions across the Hanford Site and functions as an information sharing resource for the site. The Industrial Hygiene Programs Team is responsible for administering the company wide industrial hygiene program.

WESF retains an industrial hygienist to cover activities involving hazardous material. This representative is responsible for evaluating potential facility hazards, identifying appropriate monitoring procedures to ensure $\rightarrow$ compliance with a 11 pertinent exposure limits, and ensuring that areas with such hazards are properly posted and that access is controlled appropriately.

WESF industrial hygiene responsibilities relevant to hazardous materials protection also include: hazard evaluations; job hazards analyses; hazardous material identification, monitoring, and control; hazardous material assessments (under emergency conditions); and facility program implementation/administration.

The WESF organization fulfills its responsibilities by maintaining and coordinating ALARA and safety awareness programs to minimize hazards exposure, increase health and safety awareness, alert personnel to known hazards, provide continuous improvement promotions, and recognize positive safety performance.

The WESF facility team is responsible for safe facility operation. The WESF ALARA Program implements the ALARA requirements for non-radiological hazardous material. See section 6.1, Radiation Protection, for additional discussion of the WESF ALARA program. 


\section{REVIEW COMMENT RECORD (RCR)}

\begin{tabular}{|c|l|}
\hline 1. Date & 2. Review No. \\
\hline $\begin{array}{c}7 / 30 / 96 \\
\text { 3. Project No. } \\
\text { WESF }\end{array}$ & 4. Page \\
\hline
\end{tabular}

Hazardous Material Exposure Control. Record Keeping and Communication (Sig..only the two following para. were modified and only si ightly...kjw)

The WESF team, along with the appropriate work function groups have developed, implemented, and maintain a facility specific, written HAZCOM Program. Hazard Communication Program (HAZCOM) and waste management awareness training introduces workers to federal laws governing chemical safety in the work place.

The WESF respiratory protection program requires that the use of respiratory protection be planned in advance of an activity to protect employees against the inhalation of harmful air contaminants and against oxygen deficient atmospheres. Only respirators approved by the National Institute for Occupational Safety and Health and/or the Mine Safety and Health Administration are used. Employees are medically screened, fit tested and trained before using respirators. Respirator and cartridge selection for non-radiological hazards is performed by the WESF industrial hygienist. An independent annual appraisal of the respiratory protection program is conducted to assess compliance with DOE mandated standards.

Occupational Chemical Exposure (Sig...this section was extensively reworked...kjw)

宫

Requirements pertaining to occupational exposure to chemicals are addressed in the WHC controlled manuals (WHC-CM-4-40 and WHC-CM-1-11), OSHA (29CFR1910 and 29CFR1926), and the American Conference of Governmental Industrial Hygienists Threshold Limit Values (ACGIH-TLVS). These standards define management and personnel requirements and responsibilities for safe handling of these chemicals including information on training, safe handling, concentration and contamination limits, medical surveillance programs, personal protective equipment and emergency procedures.

Organizational Structure, Responsibilities and Interfaces (Sig...only the following were modified...kjw)

The WHC safety culture is achieved through the integration of safety into every operation. Each member of the team is accountable for safety performance and is responsible for assuring compliance with established procedures, practices, and planning documents. The Industrial Health and Safety Program is designed to protect the safety, health, and wellbeing of employees by anticipating, identifying, evaluating, and controlling hazards in the work place. The WESF team is required to operate the facility in compliance with appropriate federal, DOE, state, and local statutes, regulations, orders and contractual obligations.

The WESF teams operate in parallel with the WESF Management Team. The WESF specific teams are the WESF Baseline Program Control Team, the Surveillance Field Team and the Capsule Management Team. WESF teams obtain technical and professional 


\begin{tabular}{|l|l|l|l|}
\hline \multirow{2}{*}{ REVIEW COMMENT RECORD (RCR) } & 1. Date & $7 / 30 / 96$ & Review No. \\
\cline { 2 - 4 } & 3. Project No. & $4 . \quad$ Page \\
WESF & 8 of 9 \\
\hline
\end{tabular}

support in areas such as safety, training, and environmental from the Technical Support Group, a resource shared with B Plant.

Industrial Hygiene support is provided by the B Plant/WESF Technical Support Group. 


\begin{tabular}{|l|l|l|l|}
\hline \multirow{2}{*}{ REVIEW COMMENT RECORD (RCR) } & $\begin{array}{l}\text { 1. Date } \\
7 / 30 / 96\end{array}$ & 2. Review No. \\
\cline { 2 - 4 } & $\begin{array}{c}\text { 3. Project No. } \\
\text { WESF }\end{array}$ & $\begin{array}{l}\text { 4. Page } \\
9 \text { of } 9\end{array}$ \\
\hline
\end{tabular}

Safety Management Policies and Programs (Sig...slight modifications to the following para. only...kjw)

Pre-job safety $\mathrm{planning}$ by the WESF teams ensure that each job is conducted safely and that each employee understands the steps that are required to maintain an environment free of injuries. This is accomplished through both formal and informal approaches. Reporting safety performance and unusual occurrences help to measure the benefits of established safety procedures. Regular safety inspections conducted by all levels of management identify safety and housekeeping deficiencies. Deficiencies are tracked and status reports are completed and reviewed on a monthly basis.

The WHC and WESF industrial hygiene programs provide for independent overview of the WESF facility and operations to ensure compliance with industrial hygiene requirements. The industrial hygiene program at WHC/WESF is established to safeguard employee health and well-being by ensuring that exposures to harmful chemical, physical, and biological agents are ALARA and within all 1 imits prescribed by the DOE. 
WHC-SD-WM-DRR-058 Rev. 0

This page intentionally left blank. 


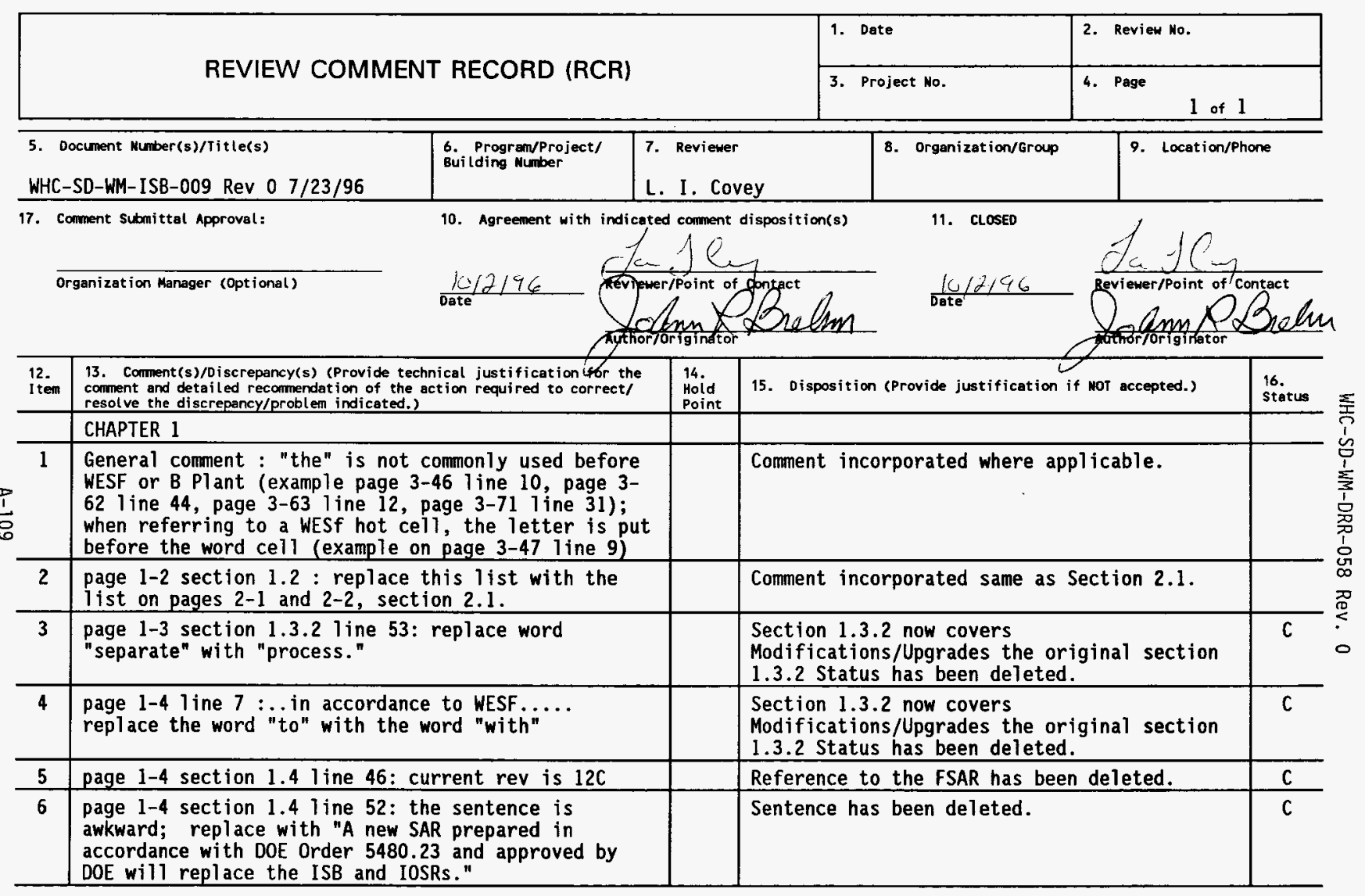




\begin{tabular}{|l|l|l|l|}
\hline REVIEW COMMENT RECORD (RCR) & 1. Date & Review No. \\
\cline { 2 - 3 } & 3. Project Mo. & 4. Page \\
\hline
\end{tabular}

\begin{tabular}{|c|c|c|c|c|}
\hline $\begin{array}{l}12 . \\
12 .\end{array}$ & $\begin{array}{l}\text { 13. Comment(s)/Discrepancy(s) (Provide technical justificat ion for the } \\
\text { comment and detailed recommendat ion of the action required to correct/ } \\
\text { resolve the discrepancy/problem indicated.) }\end{array}$ & $\begin{array}{l}14 . \\
\text { Hood } \\
\text { Point }\end{array}$ & 15. Disposition (Provide justification if NOT accepted.) & $\begin{array}{l}16 . \\
\text { Status }\end{array}$ \\
\hline 7 & $\begin{array}{l}\text { page } 1-7, \text { table under loss of containment: the } \\
\text { controls column includes SS ARMS but does not } \\
\text { include SC level instrumentation. Add the level } \\
\text { instrumentation. }\end{array}$ & & Comment deleted by Lori Covey on $8 / 2 / 96$. & C \\
\hline 8 & $\begin{array}{l}\text { page 1-8, table under BDBA: something needs to be } \\
\text { placed in the columns next to unmitigated } \\
\text { operational accidents even if it's just "NA." }\end{array}$ & & The table has been deleted. & \\
\hline 9 & $\begin{array}{l}\text { page } 1-8 \text {, section } 1.7 \text { line } 26: \text { the table referenced } \\
\text { does not compare results to EGs }\end{array}$ & & The table has been deleted. & \\
\hline \multirow[t]{2}{*}{10} & $\begin{array}{l}\text { page 1-8 section } 1.7 \text { line } 31 \text { : the hot cell B-E fire } \\
\text { is mitigated by fire suppression, this sentence says } \\
\text { it is not below guidelines with } \\
\text { mitigation/prevention }\end{array}$ & & $\begin{array}{l}\text { This section is now numbered } 1.6 \text {. The } \\
\text { discussion about the hot cell has been } \\
\text { deleted. }\end{array}$ & \\
\hline & CHAPTER 3 & & & \\
\hline 11 & $\begin{array}{l}\text { page } 3-1 \text { section } 3.1 \text { line } 31 \text { and } 49: \text { SSC is used on } \\
\text { line } 31 \text { but isn't defined until } 1 \text { ine } 49 \text {. }\end{array}$ & & Text changed to define SSC earlier. & C \\
\hline 12 & $\begin{array}{l}\text { page 3-2 line } 4: \text { replace with "....decontamination } \\
\text { and decommissioning activities, and wet storage of } \\
\text { capsules...." }\end{array}$ & & Text changed to add "wet" storage. & C \\
\hline 13 & $\begin{array}{l}\text { page } 3-4 \text { table under loss of pool cell water, } \\
\text { controls column: \#5 is not clear, a reference to the } \\
\text { pipe should be made so everyone understands what the } \\
\text { SC emergency makeup water system is }\end{array}$ & & $\begin{array}{l}\text { Fill pipe will not be added to the } \\
\text { description of the SC. }\end{array}$ & C \\
\hline 14 & $\begin{array}{l}\text { page } 3-8 \text { section } 3.3 .2 .1 \text { line } 30: \text { add to the } \\
\text { sentence "....contamination in the hot cell } \\
\text { equipment and piping." }\end{array}$ & & $\begin{array}{l}\text { The accident analysis assumes the } \\
\text { contamination is within the hot cells and } \\
\text { not contained within equipment or piping. } \\
\text { This comment is not being incorporated in } \\
\text { order to keep Chapter } 3 \text { consistent. }\end{array}$ & C \\
\hline
\end{tabular}




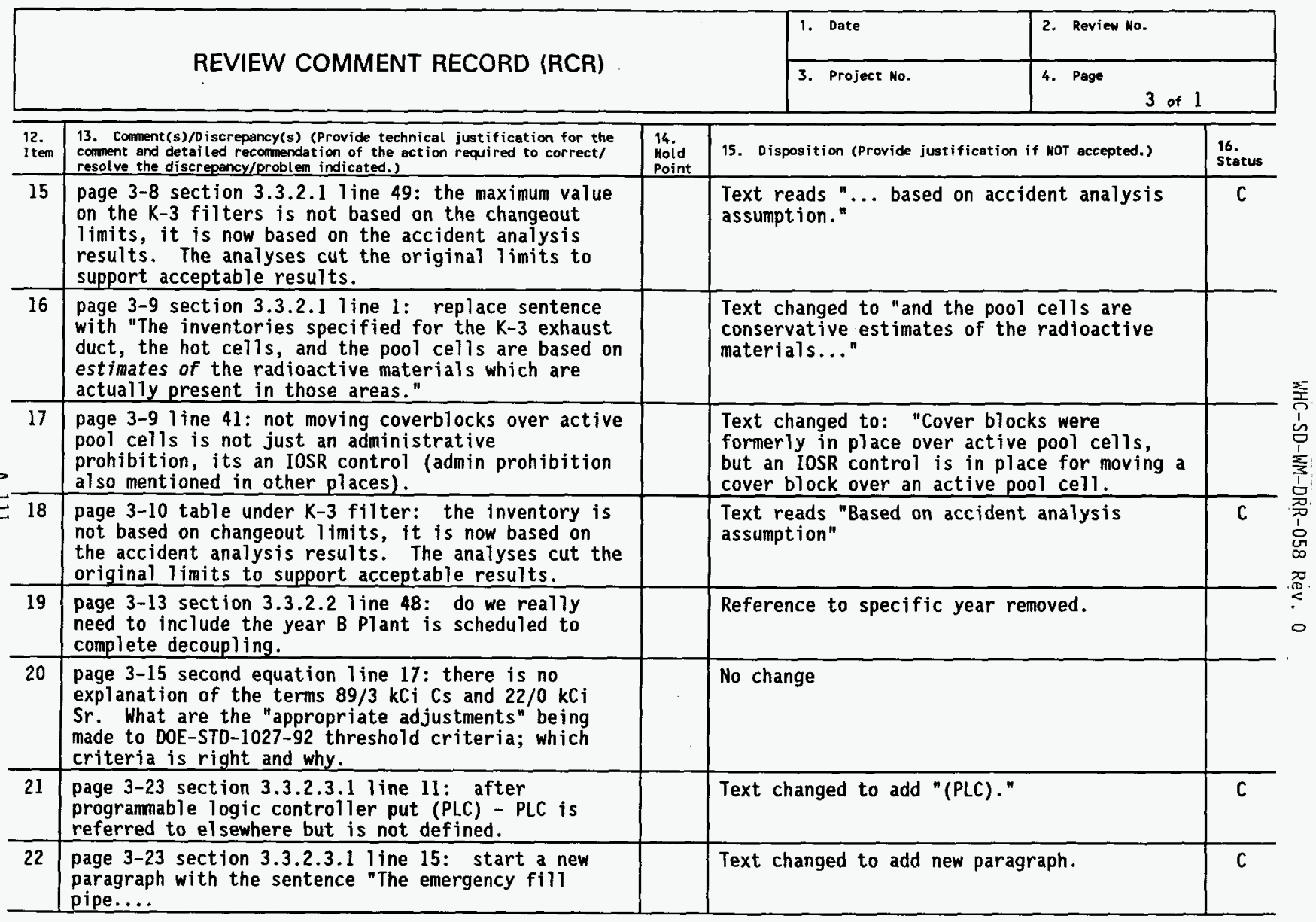

A- 6400-090.1 (03/92) WEFO11 


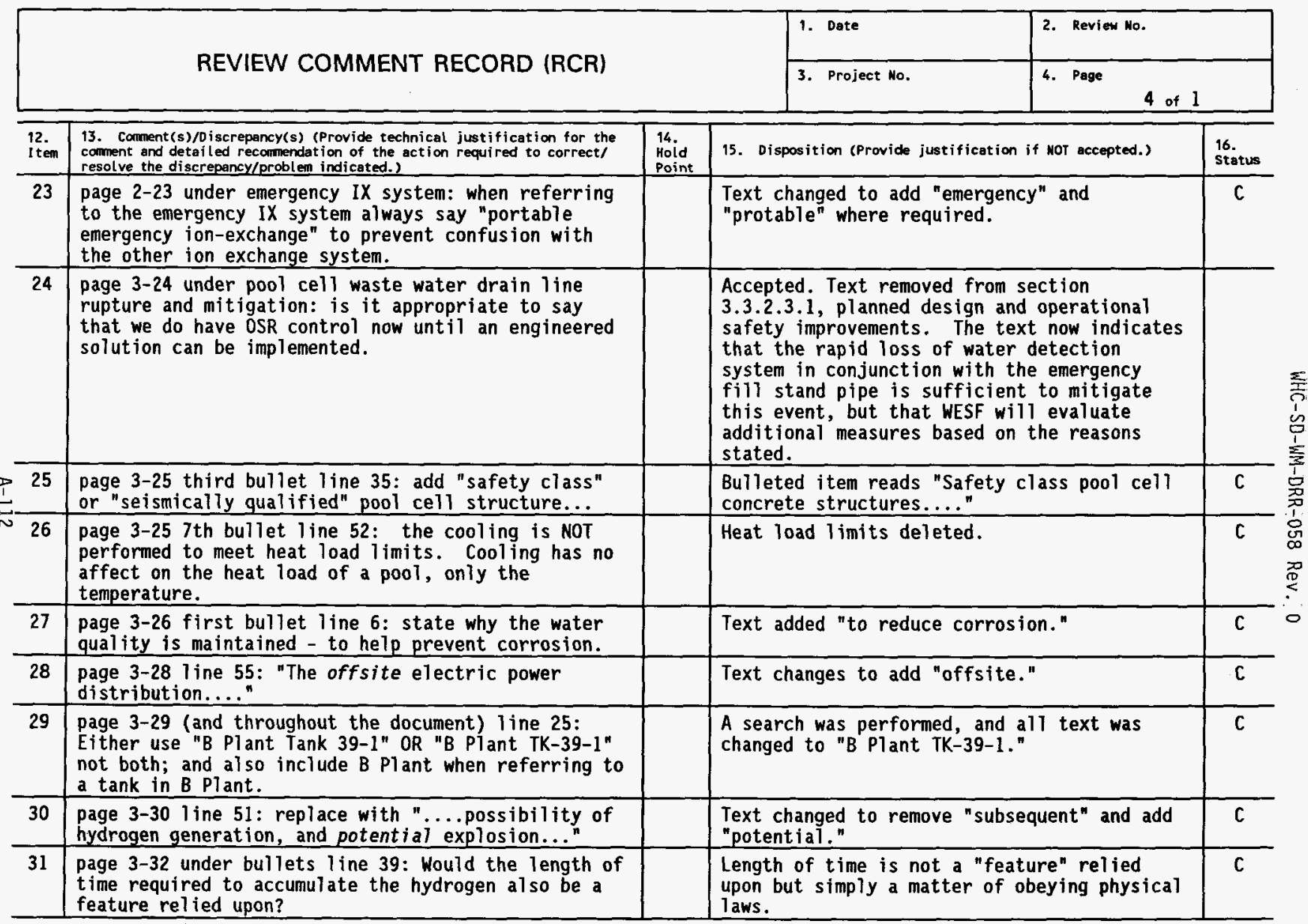

A-6400-090.1 (03/92) WEF011 


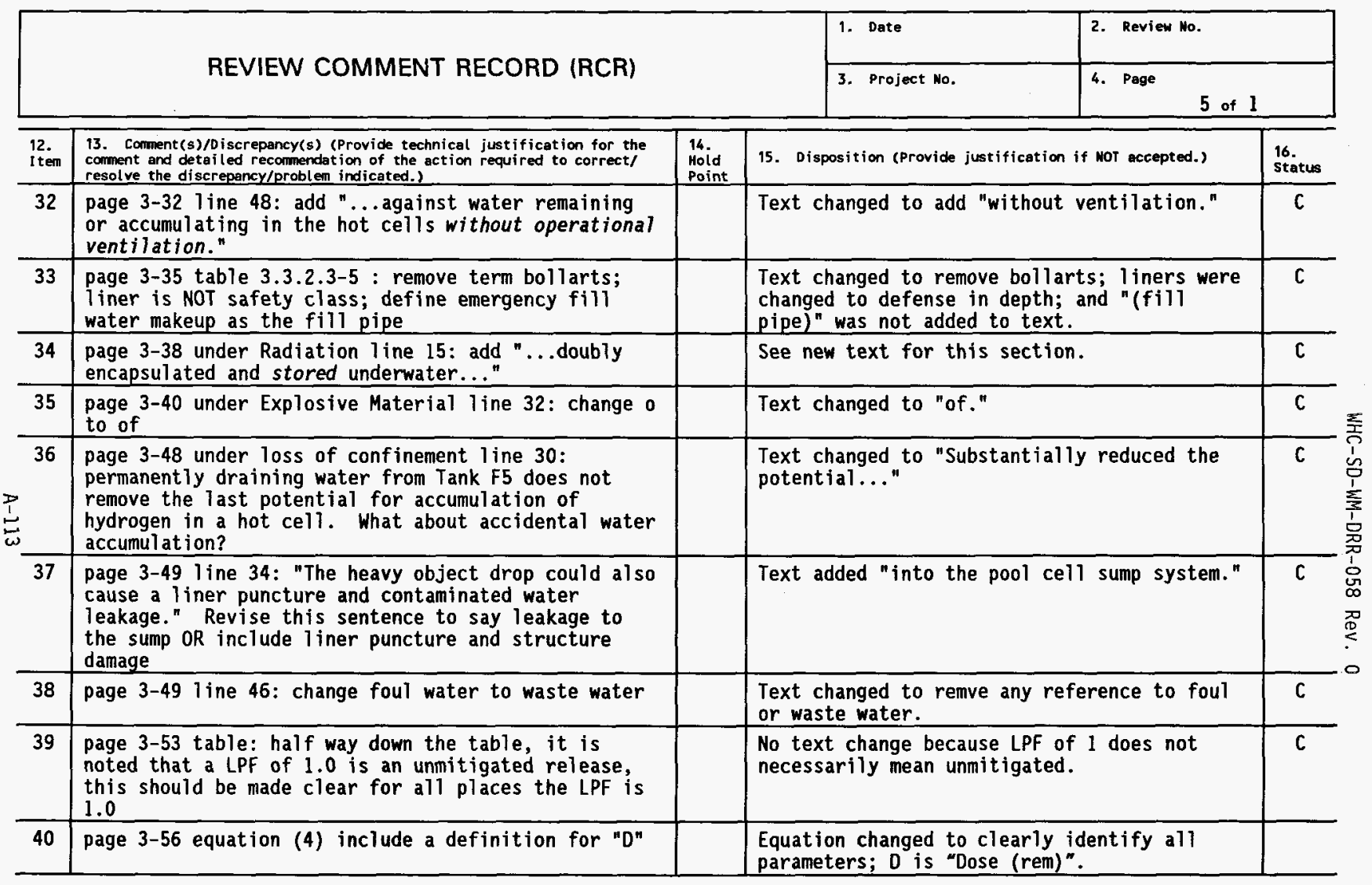




\begin{tabular}{|l|l|l|l|}
\hline \multirow{2}{*}{ REVIEW COMMENT RECORD (RCR) } & 1. Date & 2. Review No. \\
\cline { 2 - 3 } & 3. Project No. & 4. Page \\
\hline
\end{tabular}

\begin{tabular}{|c|c|c|c|c|}
\hline $\begin{array}{l}12 . \\
\text { Item }\end{array}$ & $\begin{array}{l}\text { 13. Comment(s)/Discrepancy(s) (Provide technical justification for the } \\
\text { comment and detai led recommendation of the action required to correct/ } \\
\text { resolve the discrepancy/problem indicated.) }\end{array}$ & $\begin{array}{l}\text { Th. } \\
\text { Moid } \\
\text { Point }\end{array}$ & 15. Disposition (Provide justification if wOT accepted.) & $\begin{array}{l}\text { 16. } \\
\text { Status }\end{array}$ \\
\hline 41 & $\begin{array}{l}\text { page } 3-56 \text { section } 3.4 .1 .4 \text { line } 36: \text { All accidents in } \\
\text { the ISB are not below guidelines - seismic event. }\end{array}$ & & $\begin{array}{l}\text { Text changed to reword paragraph as } \\
\text { "Therefore, for all accidents which use } \\
\text { these values as EG's, the requirement to } \\
\text { perform risk analyses has been met. All } \\
\text { accidents in this BIO fall into this } \\
\text { category." }\end{array}$ & C \\
\hline 42 & $\begin{array}{l}\text { page 3-60 \#1 line 9: when referencing the current } \\
\text { Hanford Site DBE add that it is a } 0.20 \mathrm{~g} \text {. }\end{array}$ & & Text changed to add " 0.25 gravity." & C \\
\hline 43 & $\begin{array}{l}\text { page 3-60 \#2 : Should we also add to this discussion } \\
\text { that a1l information that was found for the seismic } \\
\text { analyses was confirmed true and all recommendations } \\
\text { in the analyses were implemented or appropriately } \\
\text { dispositioned? }\end{array}$ & & $\begin{array}{l}\text { Paragraph added: "During the hazards survey } \\
\text { process, } 21 \text { structural design modification } \\
\text { recommendations, one structural evaluation } \\
\text { recommendation, and } 6 \text { equipment design } \\
\text { modification recommendations were } \\
\text { discovered. of the } 21 \text { structural } \\
\text { recommendations, } 16 \text { had been completed and } 5 \\
\text { were not neccessary. The single } \\
\text { recommendation for further evaluation, } \\
\text { pertaining to a stack located on the Area } 1 \\
\text { structure, was al so not neccessary. of the } \\
6 \text { equipment design recommendations, } 3 \text { were } \\
\text { performed, } 2 \text { were not neccessary because of } \\
\text { equipment changes, and } 1 \text { was not } \\
\text { incorporated. The equipment design } \\
\text { modification not incorporated is the seismic } \\
\text { anchoring of the k-3 filter boxes." }\end{array}$ & \\
\hline 44 & $\begin{array}{l}\text { page } 3-61 \text { section } 3.4 .2 .1 .2 \text { line } 24 \text { add reference to } \\
0.20 \mathrm{~g} \text {. }\end{array}$ & & Text changed to add "0.20 gravity." & C \\
\hline 45 & $\begin{array}{l}\text { page 3-64 line 12: missing words in this sentence } \\
\text { "..displacement of the filter box itself, with a } \\
\text { subsequent? of the inlet and outlet ducting." }\end{array}$ & & $\begin{array}{l}\text { Text changed to make sentence clearer } \\
\text { "...displacement of the filter box itself. } \\
\text { This breach could result in a bypass of the } \\
\text { of the filter box..." }\end{array}$ & C \\
\hline
\end{tabular}




\begin{tabular}{|l|l|}
\hline 1. Date & 2. Review Mo. \\
\hline 3. Project No. & 4. Page 7 of 1 \\
\hline
\end{tabular}

\begin{tabular}{|c|c|c|c|c|}
\hline $\begin{array}{l}12 . \\
\text { Item }\end{array}$ & $\begin{array}{l}\text { 13. Comment(s)/D iscrepancy(s) (Provide technical justification for the } \\
\text { coment and detailed recommendation of the action required to correct/ } \\
\text { resolve the discrepancy/problem indicated.) }\end{array}$ & $\begin{array}{l}\text { 14. } \\
\text { Hoid } \\
\text { Point }\end{array}$ & 15. Disposition (Provide justification if NOT accepted.) & $\begin{array}{l}\text { 16. } \\
\text { Status }\end{array}$ \\
\hline 46 & $\begin{array}{l}\text { page } 3-64 \text { under delayed effects } 1 \text { ine } 25: \text { reference } \\
\text { the calcs for the days to evaporate water; state } \\
\text { what the heat load used was }(149,000 \mathrm{~kW}) ; \text { state the } \\
\text { assumed evaporation rate ( } 1 \mathrm{in} / \mathrm{hr} \text { ?) }\end{array}$ & & $\begin{array}{l}\text { The discussion references Hey (1996) as the } \\
\text { basis of the number. }\end{array}$ & \\
\hline 47 & $\begin{array}{l}\text { page } 3-71 \text { and } 3-72 \text { verify the } B \text { Plant results being } \\
\text { referenced with the revised } B \text { Plant analyses. } \\
\text { Several referenced accidents have also been } \\
\text { eliminated. }\end{array}$ & & No text change - results have been verified. & C \\
\hline 48 & $\begin{array}{l}\text { page } 3-76 \text { 1ine } 48: \text {... can be determined by } \\
\text { estimating by comparing..." }\end{array}$ & & Text changed to delete "by estimating." & C \\
\hline 49 & $\begin{array}{l}\text { page 3-80 under unmitigated line 25: Remove } \\
\text { sentence "However, the distribution.... thus } \\
\text { maximizing the calculated release." replace with } \\
\text { new paragraph and make appropriate changes to } \\
\text { calculations and reference (see next comment for } \\
\text { correct references to add); "All past processing } \\
\text { within the hot cells was completed within vessels, } \\
\text { piping and equipment. The cells and vessels were } \\
\text { flushed following the completion of cesium and } \\
\text { strontium processing (Adams } 1984 \text {, Calstrom 1985). } \\
\text { Approximately ninety prevent of the contamination in } \\
\text { contained within the cells. The only contamination } \\
\text { which would be outside the cells resulted from } \\
\text { spills (the cells were washed down after processing) } \\
\text { and any contamination resulting from the transfer of } \\
\text { waste to A Cell. Therefore, the facility estimates } \\
\text { that approximately 90\% of the contamination within } \\
\text { the cell would be within the vessels, equipment and } \\
\text { piping. Conservatively, it is assumed that 50\% is } \\
\text { contained on the combustibles." (Several locations } \\
\text { throughout the document would need to be revised } \\
\text { based on this change) }\end{array}$ & & $\begin{array}{l}\text { If reviewed and documented appropriately, } \\
\text { such data can be used in the accident } \\
\text { analysis. However, this data would not } \\
\text { likely alter the conclusions of any accident } \\
\text { except, possibly, the hot fire analysis } \\
\text { which already demonstrates adequate } \\
\text { controls. In addition, inclusion of such } \\
\text { data would have impacts on many sections of } \\
\text { the document and require extensive time to } \\
\text { incorporate, not counting the time required } \\
\text { to review and document the data. Therefore, } \\
\text { this comment is not being incorporated at } \\
\text { this time, but will be considered during } \\
\text { preparation of the facility SAR. }\end{array}$ & \\
\hline
\end{tabular}




\begin{tabular}{|l|l|}
\hline 1. Date & 2. Review No. \\
\hline 3. Project No. & 4. Page 8 of 1 \\
\hline
\end{tabular}

\begin{tabular}{|c|c|c|c|c|}
\hline $\begin{array}{l}12 . \\
\text { Item }\end{array}$ & $\begin{array}{l}\text { 13. Comment(s)/Discrepancy(s) (Provide technical justification for the } \\
\text { comment and detailed recommendation of the action required to correct/ } \\
\text { resolve the discrepancy/problem indicated.) }\end{array}$ & $\begin{array}{l}14 \text { Hold } \\
\text { Hoid } \\
\text { Point }\end{array}$ & 15. Disposition (Provide justification if MOT accepted.) & $\begin{array}{l}16 . \\
\text { status }\end{array}$ \\
\hline 50 & $\begin{array}{l}\text { References for above comment: SD-WM-ER-014 "WESF } \\
\text { Cesium Line Standby/Survei11 ance" LL Adams April } \\
1984 ; \text { SD-WM-ER-022 "WESF Strontium Line } \\
\text { Standby/Surveillance" RF Carlstom May } 1985\end{array}$ & & $\begin{array}{l}\text { No text change required since comment } 49 \text { was } \\
\text { not incorporated. }\end{array}$ & C \\
\hline 51 & $\begin{array}{l}\text { page 3-80 under Unmitigated line } 21: \text { The first } \\
\text { sentence "Also, since the wastes...... cellulosic } \\
\text { combustibles" doesn't have a verb. }\end{array}$ & & Text changed, see rewrite of the section. & C \\
\hline 52 & $\begin{array}{l}\text { page 3-81 line } 7: \text { The document states that when the } \\
\text { concentration of oxygen reaches } 11 \% \text { the combustion } \\
\text { should be ext inguished. Why do we in line } 11 \text { assume } \\
\text { that we burn all the oxygen before the fire is } \\
\text { extinguished? (A change here would also affect } \\
\text { other areas throughout the document.) }\end{array}$ & & $\begin{array}{l}\text { The analysis states that this assumption is } \\
\text { made for the sake of simplicity and } \\
\text { conservatism. It was found that altering } \\
\text { the assumption to } 11 \% 0_{2} \text { instead of all the } \\
0_{2} \text { resulted in no impact to the conclusions } \\
\text { of the analysis. On the other hand, this } \\
\text { assumption gave us a margin against the } \\
\text { assumption that no } 0_{2} \text { infiltrates into the } \\
\text { combustion cell during the fire. }\end{array}$ & \\
\hline 53 & $\begin{array}{l}\text { page 3-94 first bullet line 8: replace "..protects } \\
\text { the waste cask by keeping it cool in the event of } \\
\text { fire..." }\end{array}$ & & $\begin{array}{l}\text { See Section } 3.4 .2 .3 .2 .5 " \ldots \text { the truckport } \\
\text { fire suppression system cools the waste } \\
\text { cask..." }\end{array}$ & C \\
\hline 54 & $\begin{array}{l}\text { page } 3-102 \text { last bullet line } 51 \text { : the nominal hot } \\
\text { cell flow is not } 250 \mathrm{cfm} \text {, that is the max flow. }\end{array}$ & & $\begin{array}{l}\text { Since the } 250 \mathrm{cfm} \text { is actually a "minmum" } \\
\text { allowable flowrate, the control is changed } \\
\text { to a maximum of } 1.8 \mathrm{~kW} \text { thermal load in the } \\
\text { cell (based on the thermal analysis). The } \\
250 \mathrm{cfm} \text { minimum flowrate is retained in the } \\
\text { bullet with a sentence following the } \\
\text { controls showing a thermal load of } 1.8 \mathrm{kw} \text { as } \\
\text { an alternative. }\end{array}$ & \\
\hline 55 & $\begin{array}{l}\text { page } 3-1093.4 .22 .4 .3 .21 \text { ine } 41 \text { : the LFL of } \\
\text { hydrogen is referred to here - add that the LFL is } \\
4 \% \text {. }\end{array}$ & & $\begin{array}{l}\text { Text changed to add " }(4 \%) . " \text { See } \\
3.4 .2 .4 .3 .1 \text {. }\end{array}$ & C \\
\hline
\end{tabular}




\begin{tabular}{|l|l|}
\hline 1. Date & 2. Review No. \\
\hline 3. Project Mo. & 4. Page 9 of 1 \\
\hline
\end{tabular}

\begin{tabular}{|c|c|c|c|c|}
\hline $\begin{array}{l}12 . \\
\text { Item }\end{array}$ & $\begin{array}{l}\text { 13. Comment( } s) / \text { iscrepancy(s) (Provide technical justification for the } \\
\text { comment and detai led recommendation of the action required to correct/ } \\
\text { resolve the discrepancy/problem indicated.) }\end{array}$ & $\begin{array}{l}14 . \\
\text { Hoid } \\
\text { Point }\end{array}$ & 15. Disposition (Provide justification if NOT accepted.) & $\begin{array}{l}\text { 16. } \\
\text { Status }\end{array}$ \\
\hline 56 & $\begin{array}{l}\text { page } 3-110 \text { under hot cell flood line } 10: 20 \mathrm{R} / \mathrm{hr} \\
\text { needs to be confirmed as the correct dose reading }\end{array}$ & & $\begin{array}{l}\text { Text changed to remove all references to } 20 \\
\mathrm{R} / \mathrm{hr} \text { and to add the inventory assumed in the } \\
\text { accident analyses. }\end{array}$ & C \\
\hline 57 & $\begin{array}{l}\text { page } 3-110 \text { generation rate equation line } 21 \text { : a } \\
\text { reference for this equation needs to be added; a } \\
\text { reference for the " } G \text { " term of } 0.45 \text { molecules per } \\
\text { l00ev; and a reference for the beta and gamma decay } \\
\text { energies }\end{array}$ & & Hey (1996) is referenced. & \\
\hline 58 & $\begin{array}{l}\text { page } 3-110 \text { decay energy equation for } \mathrm{Cs}, \mathrm{H} 20 \text { : the } \\
\text { paragraph above says gamma is } 0.184 \mathrm{Mev} / \mathrm{dis} \text {, the } \\
\text { equation uses } 0.182 \mathrm{Mev} / \mathrm{dis} \text {. Correct the equation. }\end{array}$ & & Text changed to add 0.184 . & C \\
\hline 59 & $\begin{array}{l}\text { page 3-111 time equation line } 5: \text { there is no basis } \\
\text { for the amount of free volume or volume of water } \\
\text { assumed in this calculation ( } 156 \text { cubic feet). There } \\
\text { is also no reason given for using } 4 \% \text { - add that its } \\
\text { the LFL. }\end{array}$ & & $\begin{array}{l}\text { See revised paragrapy preceding time } \\
\text { calculation. }\end{array}$ & \\
\hline 60 & $\begin{array}{l}\text { page } 3-112 \text { under unmitigated condition line } 18: \\
\text { "...inventory assumed to be present on the HEPA..." }\end{array}$ & & Text changed to add "be." & C \\
\hline 61 & $\begin{array}{l}\text { page 3-113 under major assumptions line } 12 \text { : The } \\
\text { contamination of the } \mathrm{K}-3 \text { filters should be given in } \\
\text { curies as well as } \mathrm{R} / \mathrm{hr} \text {. }\end{array}$ & & $\begin{array}{l}\text { Text changed to remove all references to } 20 \\
R / h r \text { and to add the inventory assumed in the } \\
\text { accident analyses. }\end{array}$ & C \\
\hline 62 & $\begin{array}{l}\text { page 3-116 under unmitigated condition line } 30: \\
\text { missing words in the sentence "...methodology used } \\
\text { to determine? consist of the....." }\end{array}$ & & Sentence deleted. & C \\
\hline 63 & $\begin{array}{l}\text { page } 3-116 \text { unmitigated condition: why does the hot } \\
\text { cell hydrogen accumulation and the TK-100 and K-3 } \\
\text { hydrogen accumulation use different equations? This } \\
\text { basis should be included. }\end{array}$ & & $\begin{array}{l}\text { Text changed - TK-100 and hot cell equations } \\
\text { include diffusion which cannot be used for } \\
\text { K-3. NOTE: it was discovered that the model } \\
\text { development in this section was inconsistent } \\
\text { and has been revised. }\end{array}$ & C \\
\hline
\end{tabular}




\begin{tabular}{|l|l|}
\hline 1. Date & 2. Review No. \\
\hline 3. Project Mo. & 4. Page 10 of 1 \\
\hline
\end{tabular}

\begin{tabular}{|c|c|c|c|c|}
\hline $\begin{array}{l}12 . \\
\text { Item }\end{array}$ & $\begin{array}{l}\text { 13. Comment(s)/Discrepancy(s) (Provide technical justification for the } \\
\text { comment and detai led reconmendation of the action required to correct/ } \\
\text { resolve the discrepancy/problem indicated.) }\end{array}$ & $\begin{array}{l}14 . \text {. } \\
\text { Hold } \\
\text { Point }\end{array}$ & 15. Disposition (Provide justification if MOT accepted.) & $\begin{array}{l}16 . \\
\text { Status }\end{array}$ \\
\hline 64 & $\begin{array}{l}\text { page 3-117 under hydrogen generation rate } \\
\text { calculation } 1 \text { ine } 25: \text { the result here is } 1.3 \times 10 \mathrm{E}-4 \text {, } \\
\text { section } 3.4 .2 .4 .3 .2 \text { got } 1.4 \times 10 \mathrm{E}-4 \text { for the same } \\
\text { numbers. These results need to be consistent. }\end{array}$ & & $\begin{array}{l}\text { Text changed in section } 3.4 .2 .4 .3 .2 \text { to } 1.3 \mathrm{X} \\
10 \mathrm{E}-4 \text {. }\end{array}$ & C \\
\hline 65 & $\begin{array}{l}\text { page } 3-123 \text { under hydrogen accumulation in } B / C \text { Cell } \\
\text { line } 47: \text { refer back to references for the numbers } \\
\text { used in the equations. }\end{array}$ & & $\begin{array}{l}\text { Text change- the model development in this } \\
\text { section was inconsistent and has been } \\
\text { revised. }\end{array}$ & C \\
\hline 66 & $\begin{array}{l}\text { page } 3-123 \text { under hydrogen accumulation in } \mathrm{B} / \mathrm{C} \text { Cell } \\
\text { line } 48: \text { mijs ing words "The } 90 \mathrm{~S} / 90 \mathrm{Yt} \text { contribution } \\
\text { is } 8.4 \times 10^{14} \text { " }\end{array}$ & & $\begin{array}{l}\text { Text has been rearranged to add the results } \\
\text { of the equation in the correct location. }\end{array}$ & C \\
\hline 67 & $\begin{array}{l}\text { page 3-124 Qvent equation line 8: the area of the } \\
\text { pipe is } 178 \mathrm{sq} \mathrm{cm} \text { not } 182 \mathrm{sq} \mathrm{cm} \text { (based on } 7.5 \mathrm{~cm} \\
\text { radius). This gives an answer of } 2.21 \mathrm{E}-4 \text { instead } \\
\text { of } 2.26 \mathrm{E}-4 \text {. This needs to be followed thru in the } \\
\text { subsequent equations. }\end{array}$ & & Text and equations have been corrected. & C \\
\hline 68 & $\begin{array}{l}\text { page } 3-1275 \text { th bullet line } 13: \text { add } \mathrm{Bq}^{\prime} \mathrm{s} \text { for } 20,000 \\
\mathrm{Ci} \text {; last bullet line } 30 \text { add } \mathrm{kC} i \text { 's for the } 3.48 \text { El6 } \\
\mathrm{Bq} \text {. }\end{array}$ & & $\begin{array}{l}\text { Text has been changed to include both Bq's } \\
\text { and } \mathrm{Ci} \text { 's. }\end{array}$ & C \\
\hline 69 & $\begin{array}{l}\text { page 3-128 section } 3.4 .2 .4 .5 .4 \text { and } 3.4 .2 .4 .5 .5 \text { lines } \\
21 \text { and } 29: \text { the paragraph on Comparison to } \\
\text { Guide } 1 \text { ines says the consequences are assumed to } \\
\text { affect the onsite worker and the public - the next } \\
\text { section on Credited Controls says the controls are } \\
\text { based upon worker safety and defense in depth } \\
\text { consideration. These two sentences seem to } \\
\text { conflict. }\end{array}$ & & $\begin{array}{l}\text { Text change - section } 3.4 .2 .4 .5 .4 \\
\text { Comparison to Guidel ines now reads "No } \\
\text { comparison is provided for this event." }\end{array}$ & C \\
\hline 70 & $\begin{array}{l}\text { page 3-137: separate the figure title from the rest } \\
\text { of the text, it currently blends together and is } \\
\text { confusing. }\end{array}$ & & See Table 3-27, table has been revised. & \\
\hline 71 & $\begin{array}{l}\text { Page 3-137 figure 3.4.2.6-1: label the right axis as } \\
\text { well. }\end{array}$ & & See revised Table 3-27. & \\
\hline
\end{tabular}




\begin{tabular}{|l|l|}
\hline 1. Date & 2. Review No. \\
\hline 3. Project Mo. & 4. Page 11 of 1 \\
\hline
\end{tabular}

\begin{tabular}{|c|c|c|c|c|}
\hline $\begin{array}{l}12 . \\
\text { Item }\end{array}$ & $\begin{array}{l}\text { 13. Corment(s)/D iscrepancy(s) (Provide technical justification for the } \\
\text { comment and detai led recommendation of the act ion required to correct/ } \\
\text { resolve the discrepancy/problem indicated.) }\end{array}$ & $\begin{array}{l}14 . \\
\text { Hold } \\
\text { Point }\end{array}$ & 15. Disposition (Provide justification if wOT accepted.) & $\begin{array}{l}16 . \\
\text { Status }\end{array}$ \\
\hline 72 & $\begin{array}{l}\text { page } 3-138 \text { and throughout document: do not use clunk } \\
\text { test, use inner capsule movement test (ICM). }\end{array}$ & & $\begin{array}{l}\text { Text change - Search was completed to } \\
\text { replace "clunk test with ICM test" and } \\
\text { "clunk" with "impact." }\end{array}$ & C \\
\hline 73 & $\begin{array}{l}\text { page 3-14 figure } 3.4 .2 .6-2 \text { : add approximate location } \\
\text { of fill pipe and dose rate. }\end{array}$ & & $\begin{array}{l}\text { Dose rates for the leaking capsule scenario } \\
\text { are taken from the Orme report which does } \\
\text { not include a dose rate at the north door. }\end{array}$ & \\
\hline 74 & $\begin{array}{l}\text { page } 3-142 \text { section } 3.4 .2 .6 .2 .1 \text { line } 29: \text { if the } \\
\text { document is going to say that there could be a leak } \\
\text { to the ground, then it will be damage to the liner } \\
\text { AND the structure. Also } 1 \text { ine } 44 \text { "1 " a breach of } \\
\text { the pool cell liner and structure" }\end{array}$ & & Text change to add "and structure." & C \\
\hline 75 & $\begin{array}{l}\text { page } 3-142 \text { section } 3.4 .2 .6 .2 .1 \text { line } 37: \text { don't use } \\
\text { the term co-located worker, use onsite worker. }\end{array}$ & & Text changed "co-located" to "onsite." & $\mathrm{C}$ \\
\hline 76 & $\begin{array}{l}\text { page 3-143 line 38: revise sentence "Because of } \\
\text { concerns over dropping } \\
\text { the coverblocks were removed..." }\end{array}$ & & $\begin{array}{l}\text { Text changed to remove "hydrogen } \\
\text { accumulation." }\end{array}$ & C \\
\hline 77 & $\begin{array}{l}\text { page } 3-145 \text { section } 3.4 .2 .6 .2 .3 \text { equation } 1 \text { ine } 15: \\
\text { reference for the equation and define each of the } \\
\text { terms. }\end{array}$ & & $\begin{array}{l}\text { Reference for the equation added, as well as } \\
\text { a definition for all terms. }\end{array}$ & \\
\hline 78 & $\begin{array}{l}\text { page 3-147 under pool cel1 liner leak due to } \\
\text { corrosion line } 23 \text { : remove "currently weekly" from } \\
\text { the sentence. Also, replace sentence "Each pool } \\
\text { cell sump..... sump standpipes (Hey 1996)" with "Each } \\
\text { pool cell sump is an independent closed system with } \\
\text { a capacity of approximately } 2271 \text { (60 gal) including } \\
\text { the capacity of the sump standpipes up to the } 156 \\
\text { inch level." }\end{array}$ & & $\begin{array}{l}\text { Text change to remove "currently weekly" and } \\
\text { revise sentence to : "Each pool cell sump is } \\
\text { an independent closed system with a capacity } \\
\text { of approximately } 60 \text { gallons including the } \\
\text { capacity of the sump standpipes up to the } \\
396 \mathrm{~cm} \text { (156 in.) level (Hey 1996)." }\end{array}$ & C \\
\hline
\end{tabular}




\begin{tabular}{|l|l|}
\hline 1. Date & 2. Review No. \\
\hline 3. Project No. & 4. Page 12 of 1 \\
\hline
\end{tabular}

\begin{tabular}{|c|c|c|c|c|}
\hline $\begin{array}{l}12 . \\
\text { Item }\end{array}$ & $\begin{array}{l}\text { 13. Comment( }(s) / D \text { iscrepancy(s) (Provide technical justification for the } \\
\text { corment and detailed recommendation of the action required to correct/ } \\
\text { resolve the discrepancy/problem indicated.) }\end{array}$ & $\begin{array}{l}14 . \\
\text { Hoid } \\
\text { Point }\end{array}$ & 15. Disposition (Provide justification if MOT accepted.) & $\begin{array}{l}16 . \\
\text { Status }\end{array}$ \\
\hline 79 & $\begin{array}{l}\text { page 3-148 under pool cell drain line failure line } \\
39: \text { Remove the following sentence "A conductivity } \\
\text { probe leak detector is provided in the pipe tunnel." } \\
\text { Provide a reference for the frequency of a pipe } \\
\text { leak. remove the last } 2 \text { sentences "The failure of a } \\
\text { probe.... still in the credible range." }\end{array}$ & & $\begin{array}{l}\text { Text changed to : "Video pictures taken in } \\
1995 \text { showed no evidence of water leaking in } \\
\text { the pipe tunnel. In addition, the drain } \\
\text { line piping was evaluated in Wagenblast } \\
\text { (1996) and found to be structurally capable } \\
\text { of withstanding DBE loads without exceeding } \\
\text { allowable stress levels. However, based on } \\
\text { industry data, the frequency of a drain pipe } \\
\text { leak in the pipe tunnel has been determined } \\
\text { to be } 1.3 \times 10^{-3} \text { yr from Hey (1996)." }\end{array}$ & C \\
\hline 80 & $\begin{array}{l}\text { page 3-150 under inadvertent draining } 1 \text { ine } 24: \text { add } \\
\text { reference to figure } 3.4 .2 .6-2 \text { for the fill pipe; } \\
\text { revise sentence "An emergency fill standpipe is to } \\
\text { installed through the north wall of WESF in } \\
\text { fistar } 1996 \text {. }\end{array}$ & & $\begin{array}{l}\text { Text changed to remove "to be" and "in } \\
\text { fiscal year } 1996 . "\end{array}$ & $\mathbf{0}$ \\
\hline 81 & $\begin{array}{l}\text { page } 3-150 \text { line } 32 \text { : explain the } 20-120 \mathrm{rem} / \mathrm{hr} \text { at } \\
\text { the fill pipe; I thought the number was } 29 \mathrm{R} / \mathrm{hr} \text {. Is } \\
\text { the difference due to different pool cells being } \\
\text { drained? }\end{array}$ & & $\begin{array}{l}\text { Accepted. Text added: "... depending on the } \\
\text { water level in the pool cell at the time } \\
\text { that the hose connection is made." }\end{array}$ & \\
\hline 82 & $\begin{array}{l}\text { page } 3-153 \text { line } 16: \text { reference for filter efficiency; } \\
\text { section } 3.4 .2 .7 .1 .3 \text { remove term co-located } \\
\text { worker and replace with onsite }\end{array}$ & & $\begin{array}{l}\text { Search performed for all occurrences on } \\
\text { efficiency and decontamination factor; at } \\
\text { each location text added to state that the } \\
\text { number is assumed. The text already } \\
\text { supports this by indicating that there are } 2 \\
\text { stages of HEPA filtration. Also, text } \\
\text { changed from "co-located" to onsite." }\end{array}$ & \\
\hline 83 & $\begin{array}{l}\text { page } 3-157 \text { \#1 line } 12 \text { : remove reference to safety } \\
\text { showers, no longer in facility; line } 20 \text { : water is } \\
\text { deionized not demineralized }\end{array}$ & & $\begin{array}{l}\text { Text changed to remove reference to safety } \\
\text { showers; completed search to replace } \\
\text { demineralized with deionized. }\end{array}$ & C \\
\hline 84 & $\begin{array}{l}\text { page } 3-158 \text { figure } 3.4 .2 .7-1: \text { put more space between } \\
\text { text and figure title }\end{array}$ & & See Figure $3-6$ & \\
\hline
\end{tabular}




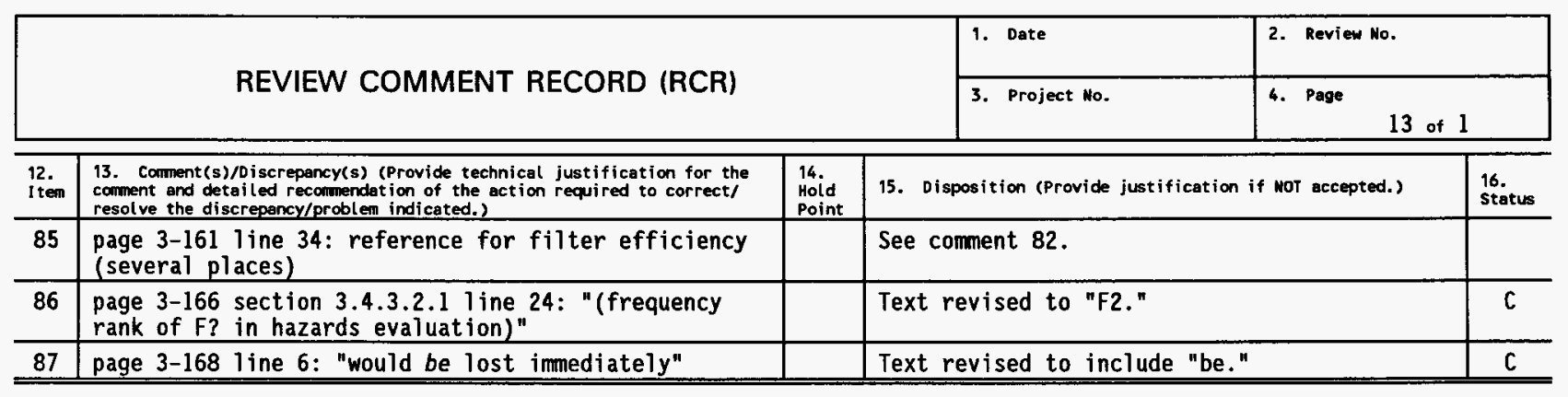

$\stackrel{1}{1}$ 
WHC-SD-WM-DRR-058 Rev. 0

This page intentionally left blank. 


\begin{tabular}{|l|l|l|}
\hline \multirow{2}{*}{ REVIEW COMMENT RECORD (RCR) } & 1. Date & 2. Review No. \\
\cline { 2 - 4 } & 3. Project No. & 4. Page \\
\hline
\end{tabular}

\begin{tabular}{l|l|l|}
\hline 5. Document Mumber(s)/Title(s) & $\begin{array}{l}\text { 6. Program/Project/ } \\
\text { Bui lding Number } \\
\text { WESF }\end{array}$ & $\begin{array}{l}\text { 7. Reviewer } \\
\text { L. I. Covey }\end{array}$ \\
WHC-SD-WM-ISB-009 Rev 0 Chapter 4 & . Cow
\end{tabular}

17. Comment submittal Approval:

Organization Manager (Optional)
8. Organization/Group

WESF Basel ine

10. Agreement with indicatęd comment disposition(s)

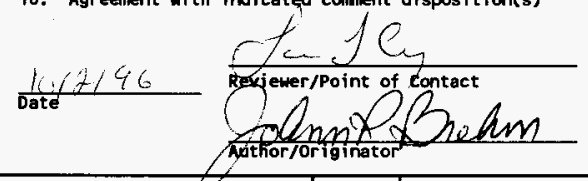

11. CLOSED

9. Location/Phone

$M 0029 / 372-0296$

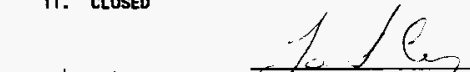

$\frac{10 / 2 / 9}{\text { Date }}$

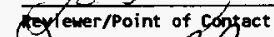

Exlewer/Point of confact

\begin{tabular}{|c|c|c|c|c|}
\hline \multicolumn{5}{|c|}{ 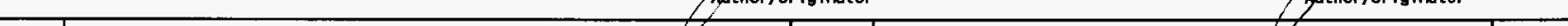 } \\
\hline $\begin{array}{l}\text { 12. } \\
\text { Item }\end{array}$ & $\begin{array}{l}\text { 13. Comment(s)/0iscrepancy(s) (Provide technical justification for the } \\
\text { comment and detailed recommendation of the act ion requi red to correct/ } \\
\text { resolve the discrepancy/problem indicated.) }\end{array}$ & $\begin{array}{l}14 . \\
\text { Hold } \\
\text { Point }\end{array}$ & 15. Disposition (Provide justification if NOT accepted.) & $\begin{array}{l}16 . \\
\text { Status }\end{array}$ \\
\hline 1 & Chapter 4 received on $8 / 04 / 96$ & & No response required. & $\mathrm{C}$ \\
\hline 2 & $\begin{array}{l}\text { page } 4-3 \text { section } 4.2 \text { : Shouldn't } 6430.1 \mathrm{~A} \text { be added to } \\
\text { the list? }\end{array}$ & & $\begin{array}{l}\text { TEXT CHANGE. DOE Order } 6430.1 \mathrm{~A} \text { has been } \\
\text { added to Section } 4.2 \text {. }\end{array}$ & C \\
\hline 3 & $\begin{array}{l}\text { page 4-5 Table } 4-1 \text { : add reference to the functional } \\
\text { requirements and system evaluation for the } \\
\text { earthquake section. }\end{array}$ & & $\begin{array}{l}\text { TEXT CHANGE. This is a summary table, } \\
\text { however, "(SDC } 4.1 \text {, Rev. 12)" will be added } \\
\text { to the funct ional requirements and } \\
\text { "(Wagenblast et al. 1996)" will be added to } \\
\text { the system evaluation. }\end{array}$ & C \\
\hline 4 & $\begin{array}{l}\text { page 4-5 Table 4-1 : A Cell Hot Cell fire - make } \\
\text { statement stronger under system evaluation, } \\
\text { "..filters will withstand the environment...." }\end{array}$ & & $\begin{array}{l}\text { TEXT CHANGE. Sentence changed to, "K-3 HEPA } \\
\text { filters will withstand ..." The change has } \\
\text { also been made to Section } 4.3 .2 .4 \text {, } 2 \text {, } \\
\text { sentence, "...the hot cell fire will not } \\
\text { breach the } \mathrm{K}-3 \text { filters..." Refers to A- } \\
\text { Cell. }\end{array}$ & C \\
\hline 5 & $\begin{array}{l}\text { page 4-5 Table 4-1 : B-E hot cell fire - under } \\
\text { safety function, the fires suppression is supposed } \\
\text { to suppress the fire, not cool. Under IOSR controls } \\
\text { - why is the diesel iisted (this goes for other } \\
\text { accidents as well), I thought that if the systems } \\
\text { failed safe and there are no immediate effects } \\
\text { resulting from the loss of power that the diesel } \\
\text { wouldn't be required? }\end{array}$ & & $\begin{array}{l}\text { TEXT CHANGE. "Retain structural } \\
\text { integrity..." }\end{array}$ & \\
\hline
\end{tabular}




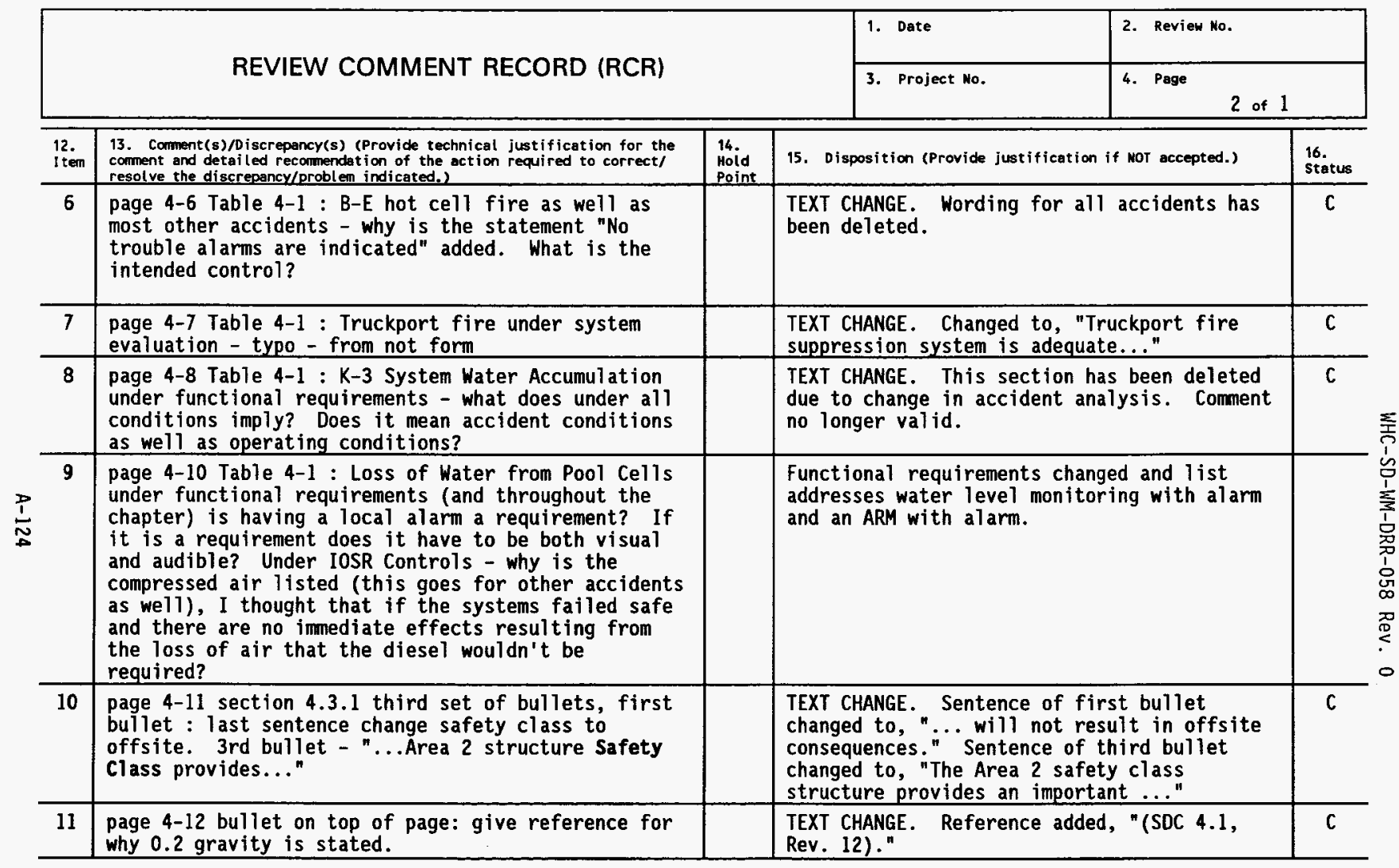




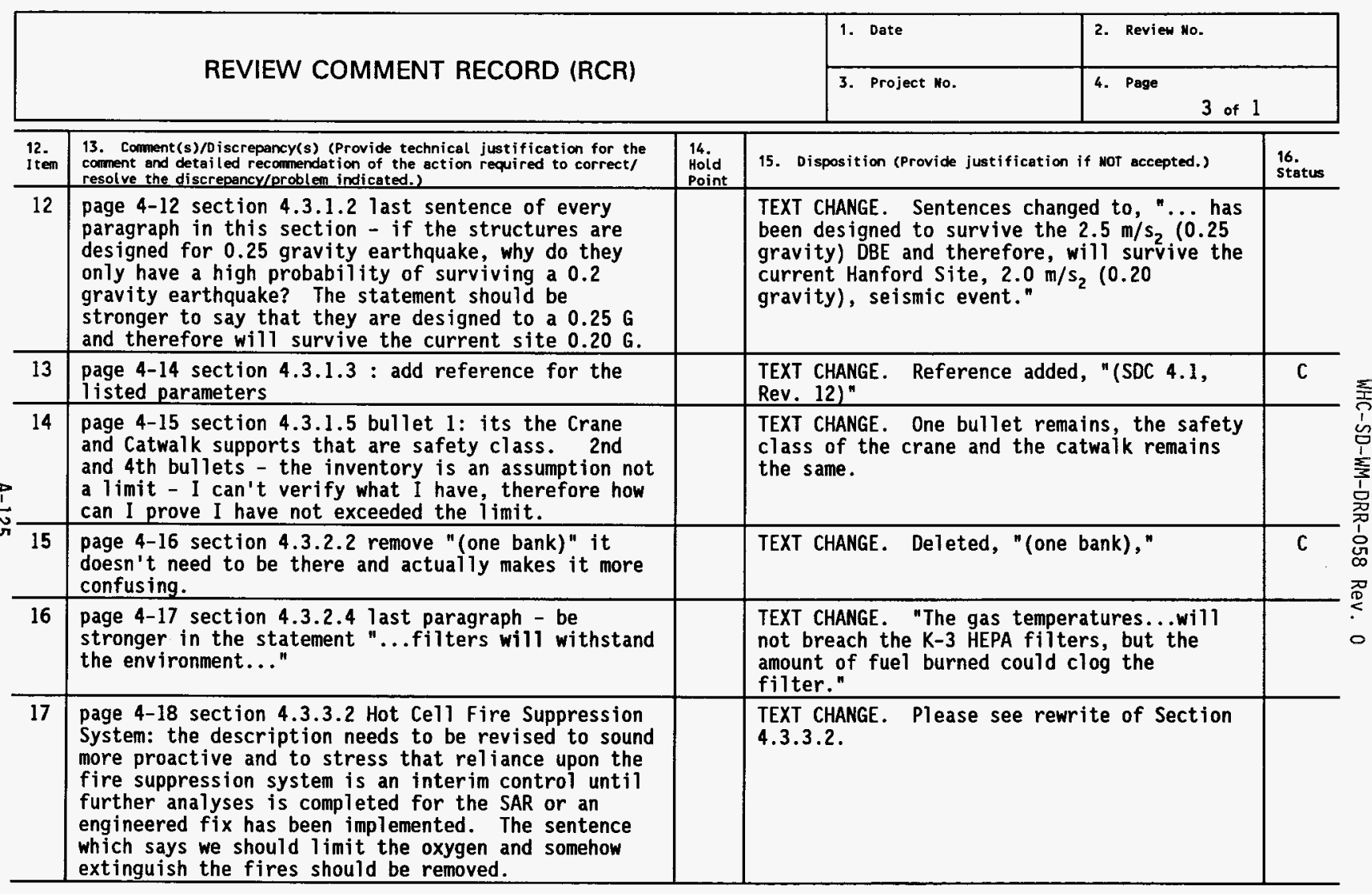




\begin{tabular}{|l|l|l|l|}
\hline \multirow{2}{*}{ REVIEW COMMENT RECORD (RCR) } & 1. Date & Review Mo. \\
\cline { 2 - 3 } & 3. Project No. & 4. Page \\
\end{tabular}

12. 13. Corment(s)/D iscrepancy(s) (Provide technical justification for the

item comment and detailed recommendation of the action required to correct/ comment and detailed recommendat ion of the
resolve the discrepancy/problem indicated.)

14.

page 4-18 section 4.3.3.2 Truckport Fire Suppression System: The water supply to the Truckport is inadequate, but the water supply to the hot cells is adequate. This section says the water supply to 225-B Building is inadequate and that statement is misleading. (this comment also applies to section 4.3.3.4 first paragraph)

19 page 4-20 section 4.3.4.2 : the air bubbler contains two diplegs which enter the filter housing, not rotometers. Remove the phrase which tells where the rotometers are located, this information is too specific. This section further states that the bubblers are required for hydrogen dilution - they are not required for this feature, its just an added bonus (defense in depth).

으 20 page 4-22 section 4.3.5.4 (and el sewhere in the chapter): the paragraph is written to say that the operators respond to the alarm inmediately as a loss of water or capsule integrity - what about when the alarm failed safe because we lost a component in the system? Shouldn't we be able to verify the condition first before responding to a loss of water or leaking capsule?

21 page 4-24 section 4.3.7.2: the range of 20-120 $\mathrm{rem} / \mathrm{hr}$ needs to be explained. Does this vary due to which pool cell is drained? Last sentence: say that even though it isn't required, it does meet safety class.

TEXT CHANGE. Section 4.3.5.4 changed to Section 4.3.4.4 and sentence changed to, "Facility personnel will respond to the alarm and evacuate the Pool Cell Area." Section 4.3.6.4 is changed to 4.3.5.4 and sentence changed to, "Facility personnel will respond to the alarm(s) and upon verifying a loss of water condition will proceed with appropriate action for ..."

TEXT CHANGE. Section number changed to 4.3.6.2, the range has been deleted. Status Hold

15. Disposition (Provide justification if not accepted.)

CHANGE. This section has been deleted due to change in accident analysis. Comment no longer valid. 


\begin{tabular}{|l|l|l|}
\hline \multirow{2}{*}{ REVIEW COMMENT RECORD (RCR) } & 1. Date & $7 / 23 / 96$ \\
\cline { 2 - 3 } & 3. Project Mo. & $4 . \quad$ Page \\
& & 1 of 9 \\
\hline
\end{tabular}

\begin{tabular}{l|l|l|l|l}
\hline 5. Document Number(s)/Title(s) & $\begin{array}{l}\text { 6. Program/Project/ } \\
\text { Building Number } \\
\text { WESF }\end{array}$ & $\begin{array}{l}\text { 7. Reviewer } \\
\text { WHC-SD-WM-ISB-009 ReV 0 7/23/96 }\end{array}$ & $\begin{array}{l}\text { 8. Organization/Group } \\
\text { L. I. Covey }\end{array}$ & $\begin{array}{l}\text { WESF Capsule Location/Phone } \\
\text { Management }\end{array}$ \\
\hline
\end{tabular}

17. Comment submittal Approval:

10. Agreement with indicated conment disposition(s)

Organization Manager (Optional)
10. Agreement with
$\frac{10 / 11 / 96}{\text { Date }}$

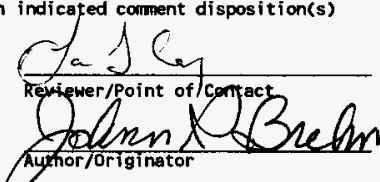

11. CLOSED \begin{tabular}{l|l}
\hline 12. & $\begin{array}{l}\text { 13. Comment(s)/oiscrepancy(s) (Provide technical justification for the } \\
\text { comment and detailed recommendation of the action required to correct/ } \\
\text { resolve the discrepancy/problem indicated.) }\end{array}$ \\
\hline
\end{tabular}

1 general comment: Pool cell and hot cell should be small letters unless associated with a number or as area (i.e Pool Cell Area).

2 page 2-3 section 2.3.1 line 29: "...cesium and strontium feed materials and encapsulation was completed in 1985."

3 page 2-3 section 2.3.1.1 line 38 "....was then loaded into a stainless steel hastelloy inner capsule..."

4 page 2-4 section 2.3.1.3 line 13: capsules were stored in pool 3 through 6 NOT 3 through 7 .

5 page 2-4 section 2.3.1.5 line 33: delete sentence "Consequently....for storage." The preferred option for the PNNL capsules is to qualify the in cell weld on the S-Type ( 3 in schedule 40 stainless steel) overpack for dry storage.

6 page 2-5 4th bullet from top line 9: mechanical scrubbing is within the scope of this document.

7 page 2-5 section 2.411 th bullet line 42: Instead of Pool Cell Leak Detection System, replace with Pool Cell Monitoring Area.
14.

\begin{tabular}{|c|c|c|}
\hline $\begin{array}{l}14 . \\
\text { Hold } \\
\text { Point }\end{array}$ & 15. Disposition (Provide justification if Nor accepted.) & $\begin{array}{l}16 . \\
\text { Status }\end{array}$ \\
\hline & Global incorporated on Chapter 2. & \\
\hline & $\begin{array}{l}\text { Text changed to read "Processing and } \\
\text { encapsulation of the cesium and strontium } \\
\text { feed materials completed in } 1985 . "\end{array}$ & \\
\hline & $\begin{array}{l}\text { Text changed to read "... was then loaded } \\
\text { into a stainless steel hastelloy inner } \\
\text { capsule..." }\end{array}$ & \\
\hline & $\begin{array}{l}\text { Text changed to read " capsules were stored } \\
\text { in pool } 3 \text { through } 6 . "\end{array}$ & \\
\hline & $\begin{array}{l}\text { Deleted sentence "Consequently.... for } \\
\text { storage." }\end{array}$ & \\
\hline & $\begin{array}{l}\text { Deleted "and Mechanical Scrubbing". Bullet } \\
\text { now reads "capsule electropolishing". }\end{array}$ & \\
\hline & $\begin{array}{l}\text { Changed "Pool Cell Leak Detection System" to } \\
\text { "Pool Cell Monitoring Area." }\end{array}$ & \\
\hline
\end{tabular}




\begin{tabular}{|c|c|c|c|c|c|}
\hline \multirow{2}{*}{\multicolumn{2}{|c|}{ REVIEW COMMENT RECORD (RCR) }} & & \multirow{2}{*}{$\begin{array}{l}\text { 1. Date } \\
\text { 3. Project No. }\end{array}$} & \multicolumn{2}{|l|}{ 2. Review No. } \\
\hline & & & & \multicolumn{2}{|c|}{2 of 9} \\
\hline $\begin{array}{l}\text { 12. } \\
\text { Item }\end{array}$ & $\begin{array}{l}\text { 13. Comment(s)/piscrepancy(s) (Provide technical justification for the } \\
\text { comment and detai ied recommendation of the action required to correct// } \\
\text { resolve the discrepancy/problen indicated.) }\end{array}$ & $\begin{array}{l}\text { 14. } \\
\text { Hoid } \\
\text { Point }\end{array}$ & \multicolumn{2}{|c|}{ 15. Disposition (Provide justification if NOT accepted.) } & $\begin{array}{l}\text { 16. } \\
\text { status }\end{array}$ \\
\hline 8 & $\begin{array}{l}\text { page } 2-7 \text { section } 2.4 .2 \text { line } 27: \text { "... between the two } \\
\text { floors areas." }\end{array}$ & & \multicolumn{2}{|c|}{$\begin{array}{l}\text { Text changed to read "Access to the Hot } \\
\text { Cells is provided by removable high-density } \\
\text { concrete cover blocks located on the floor } \\
\text { of the canyon." }\end{array}$} & \\
\hline 9 & $\begin{array}{l}\text { page 2-7 section } 2.4 .2 .1 \text { line } 37: \text { "... an oil barrier } \\
\text { which is is become electrically } \\
\text { charged as a result of the radiation exposure } \\
\text { through the lead glass windows. }\end{array}$ & & \multicolumn{2}{|c|}{$\begin{array}{l}\text { Text changed to read "...an oil barrier that } \\
\text { have become electricaliy charged as a result } \\
\text { of the radiation exposure through the lead } \\
\text { glass windows." }\end{array}$} & \\
\hline 10 & $\begin{array}{l}\text { page } 2-8 \text { section } 2.4 .2 .4 \text { line } 15: \text { "...personnel } \\
\text { entry to from the Service Gallery." }\end{array}$ & & \multicolumn{2}{|c|}{$\begin{array}{l}\text { Text changed to read "... personnel entry } \\
\text { from the Service Gallery." }\end{array}$} & \\
\hline 11 & $\begin{array}{l}\text { page 2-8 section } 2.4 .2 .51 \text { ine } 21: \text { replace sentence } \\
\text { "The A Cell has...the cel1 to B Plant" with "The A } \\
\text { Cell is equipped with a sump and steam jet as } \\
\text { described in section } 2.4 .2 .13 \text {." Use same sentence } \\
\text { for each section } 2.4 .2 .6 \text { through } 2.4 .2 .10 \text { on the hot } \\
\text { cells sump description. }\end{array}$ & & \multicolumn{2}{|c|}{$\begin{array}{l}\text { Replaced the sentence "The A Cell has...the } \\
\text { cell to B Plant" with "The A Cell is } \\
\text { equipped with a sump and steam jet as } \\
\text { described in section } 2.4 .2 .13 . " \text { and used } \\
\text { same sentence for each section } 2.4 .2 .6 \\
\text { through } 2.4 .2 .10 \text { on the hot cells sump } \\
\text { description. }\end{array}$} & \\
\hline 12 & $\begin{array}{l}\text { pages } 2-8 \text { through } 2-9 \text { sections } 2.4 .2 .6 \text { through } \\
2.4 .2 .9 \text { : the } B, C, D / E \text {, and } F \text { celis are lined with } \\
14 \text { gauge Inconel-600 alioy NOT stainless steel. } \\
\text { (Same as was described for D/E cell in section } \\
2.4 .2 .8 \text { ) }\end{array}$ & & \multicolumn{2}{|c|}{$\begin{array}{l}\text { Replaced "type 304L stainless steel" with } \\
\text { "Inconel - } 600 \text { alloy". }\end{array}$} & \\
\hline 13 & $\begin{array}{l}\text { page 2-9 section } 2.4 .2 .9 \text { line } 32 \text { : Add sentence "the } \\
\text { F Cell now contains... the inner capsules. In } \\
\text { addition, F Cell is also used for interim dry } \\
\text { storage of non-conformance capsules which cannot be } \\
\text { stored in the pool cells." }\end{array}$ & & \multicolumn{2}{|c|}{$\begin{array}{l}\text { Added the sentence "the } F \text { Cell now } \\
\text { contains... the inner capsules. In } \\
\text { addition, } F \text { Cell is al so used for interim } \\
\text { dry storage of non-conformance capsules } \\
\text { which cannot be stored in the pool cells." }\end{array}$} & \\
\hline 14 & $\begin{array}{l}\text { page } 2-9 \text { section } 2.4 .2 .10 \text { line } 51: \text { change "Most } \\
\text { activities..." to "Remote activities..." }\end{array}$ & & \multicolumn{2}{|c|}{ The sentence has been deleted. } & \\
\hline 15 & $\begin{array}{l}\text { page 2-10 line } 1: \text { "...accessible from the Service } \\
\text { Gallery (G Cell airiock)." }\end{array}$ & & \multicolumn{2}{|c|}{$\begin{array}{l}\text { Text changed to read "...accessible from the } \\
\text { Service Gallery (G Celi airlock)." }\end{array}$} & \\
\hline
\end{tabular}




\section{REVIEW COMMENT RECORD (RCR)}

\begin{tabular}{|l|l|}
\hline $\begin{array}{l}\text { 1. Date } \\
7 / 23 / 96\end{array}$ & 2. Review No. \\
\hline 3. Project No. & 4. Page \\
\end{tabular}

\begin{tabular}{|c|c|c|c|c|}
\hline $\begin{array}{l}12 . \\
\text { I tem }\end{array}$ & $\begin{array}{l}\text { 13. Comment(s)/Discrepancy(s) (Provide technical justification for the } \\
\text { comment and detailed recommendat ion of the action required to correct/ } \\
\text { resolve the discrepancy/problem indicated.) }\end{array}$ & $\begin{array}{l}14 . \\
\text { boold } \\
\text { Point }\end{array}$ & 15. Disposition (Provide justification if nOT accepted.) & $\begin{array}{l}16 . \\
\text { Status }\end{array}$ \\
\hline 16 & $\begin{array}{l}\text { page 2-10 line 7: "...transferring the capsules } \\
\text { frem between G Cel1 to and the Pool Cell Area." }\end{array}$ & & $\begin{array}{l}\text { Text changed to read "...transferring the } \\
\text { capsules between G Cell and the Pool Cell } \\
\text { Area." }\end{array}$ & \\
\hline 17 & $\begin{array}{l}\text { page } 2-10 \text { section } 2.4 .2 .12 \text { line } 30 \text { : ". WESF canyon } \\
\text { the through HEPA filters... dampers the } \\
\text { located..." "The air enters the close..." }\end{array}$ & & $\begin{array}{l}\text { The sentence now reads "The airflow is from } \\
\text { the WESF Canyon through HEPA filters and } \\
\text { flow control dampers located on the south } \\
\text { side of the canyon." }\end{array}$ & \\
\hline 18 & $\begin{array}{l}\text { page } 2-10 \text { section } 2.4 .2 .12 \text { line } 42: \text { " } \ldots \text { automatic } \\
\text { or manual control mode. possible-in the } K 3 \text {-controt } \\
\text { system." }\end{array}$ & & $\begin{array}{l}\text { Text changed to read "....automatic or } \\
\text { manual control mode." }\end{array}$ & \\
\hline 19 & $\begin{array}{l}\text { page } 2-10 \text { section } 2.4 .2 .13 \text { line } 52: \text { "...sumps in the } \\
\text { floor of each cell with the exception of } D / E \text { cell } \\
\text { which has a combined sump." }\end{array}$ & & $\begin{array}{l}\text { Text changed to read "... sumps in the floor } \\
\text { of each cell with the exception of } D / E \text { cell } \\
\text { which has a combined sump." }\end{array}$ & \\
\hline 20 & $\begin{array}{l}\text { page } 2-11 \text { section } 2.4 .2 .13 \text { line } 3: \text { "....moved through } \\
\text { the Low Level Liquid Waste System..." }\end{array}$ & & $\begin{array}{l}\text { Text changed to read "...moved through the } \\
\text { Low Level Liquid Waste System..." }\end{array}$ & \\
\hline 21 & $\begin{array}{l}\text { page } 2-11 \text { section } 2.4 .3 \text { line } 17: \text { "... personnel } \\
\text { entry door and from the Service Gallery to a from } \\
\text { the stairwell..." }\end{array}$ & & $\begin{array}{l}\text { Text changed to read "... personnel entry } \\
\text { door and from the Service Gallery to a } \\
\text { stairwell..." }\end{array}$ & \\
\hline 22 & $\begin{array}{l}\text { page } 2-11 \text { section } 2.4 .31 \text { ine } 34: \text { "...using } \\
\text { television monitors located....crane hooks and..." }\end{array}$ & & $\begin{array}{l}\text { Text changed to read "...using a television } \\
\text { monitor located.....crane hooks and..." }\end{array}$ & \\
\hline 23 & $\begin{array}{l}\text { page } 2-11 \text { section } 2.4 .4 \text { line } 45: \text { ". It was and is } \\
\text { used to service..." } i \text { ine } 49: \text { "... in airlocks (A } \\
\text { and } 6) \text { at..." } 1 \text { ine } 50: \text { "The Service Gallery.... } \\
\text { access haliway by remote electrically operated } \\
\text { switches." Delete last sentence } \\
\text { "Access...controlled." }\end{array}$ & & $\begin{array}{l}\text { Text changes to } 1 \text { ine } 45: \text { ".. It was and is } \\
\text { used to service..." } 1 \text { ine } 49: \text { "... in } \\
\text { airlocks (A and } G \text { ) at..." } 1 \text { ine } 50: \text { "The } \\
\text { Service Gallery.... access hallway by remote } \\
\text { electrically operated switches." and } \\
\text { deleted last sentence "Access...controlled." }\end{array}$ & \\
\hline 24 & $\begin{array}{l}\text { page } 2-12 \text { section } 2.4 .5 \text { line 11: "Remote work in } \\
\text { the cells..... }\end{array}$ & & $\begin{array}{l}\text { Text changed to read "Remote work in the } \\
\text { cells..." }\end{array}$ & \\
\hline 25 & $\begin{array}{l}\text { page } 2-12 \text { section } 2.4 .5 \text { line } 16 \text { : Insert sentence } \\
\text { "...Gallery. Replacement manipulators are inserted } \\
\text { into the cell using an overhead trolley." }\end{array}$ & & $\begin{array}{l}\text { Text changed to read "...Gallery. } \\
\text { Replacement manipulators are inserted into } \\
\text { the cell using an overhead trolley." }\end{array}$ & \\
\hline
\end{tabular}




\begin{tabular}{|l|l|l|}
\hline \multirow{2}{*}{ REVIEW COMMENT RECORD (RCR) } & 1. Date & 2. Review No. \\
\cline { 2 - 3 } & 3. Project No. & 4. Page \\
\hline
\end{tabular}

\begin{tabular}{|c|c|c|c|c|}
\hline $\begin{array}{l}12 . \\
\text { Item }\end{array}$ & $\begin{array}{l}\text { 13. Corment(s)/Discrepancy(s) (Provide technical justification for the } \\
\text { comment and detailed recommendation of the action required to correct/ } \\
\text { resolve the discrepancy/problem. indicated.) }\end{array}$ & $\begin{array}{l}14 . \\
\text { Hoid } \\
\text { Point }\end{array}$ & 15. Disposition (Provide justification if MOT accepted.) & $\begin{array}{l}16 . \\
\text { Status }\end{array}$ \\
\hline 26 & $\begin{array}{l}\text { page } 2-12 \text { section } 2.4 .6 \text { line } 41 \text { : revise first } \\
\text { sentence "The AMU is on the second floor of } 225-B \\
\text { and contains several unused tanks and a } 4 \mathrm{~m}^{3} \\
\text { ( } 1,000 \mathrm{gal}) \text { storage tank for deionized water." At } \\
\text { the end of the paragraph add the sentence "The } \\
\text { mezzanine contains several unused tanks and a } 2.3 \mathrm{~m}^{3} \\
(600 \text { gal) tank for decontamination solution makeup." }\end{array}$ & & $\begin{array}{l}\text { The sentence now reads "The AMU is on the } \\
\text { second floor of the } 225-B u i l d i n g \text { and } \\
\text { contains several tanks that are no longer } \\
\text { used and a } 3,785-L(1,000 \text { gal.) storage tank } \\
\text { for deionized water." and at the end of the } \\
\text { paragraph add the sentence "The mezzanine } \\
\text { contains several tanks that are no longer } \\
\text { used and a } 2.271-L \text { (600 gal) tank for } \\
\text { decontamination solution makeup." }\end{array}$ & \\
\hline 27 & $\begin{array}{l}\text { page } 2-13 \text { section } 2.4 .6 .1 \text { line } 8: \text { "The Transmitter } \\
\text { Rooms provide shielding and confinement in the } \\
\text { event....drawback." }\end{array}$ & & $\begin{array}{l}\text { Text changed to read "The Transmitter Rooms } \\
\text { provide shielding and confinement in the } \\
\text { event....drawback." }\end{array}$ & \\
\hline 28 & $\begin{array}{l}\text { page } 2-13 \text { section } 2.4 .7 \text { line } 16 \text { "...ventilation } \\
\text { supply equipment and the backup air dryer for the } \\
225-\mathrm{B} . . .\end{array}$ & & $\begin{array}{l}\text { Text changed to read "...ventilation supply } \\
\text { equipment and the backup air dryer for the } \\
\text { building" }\end{array}$ & \\
\hline 29 & $\begin{array}{l}\text { page 2-13 section } 2.4 .7 \text { line } 21: \text { "accessible from } \\
\text { the elevator, Operating Gallery and..." }\end{array}$ & & $\begin{array}{l}\text { Text changed to read "accessible from the } \\
\text { elevator, Operating Gallery and..." }\end{array}$ & \\
\hline 30 & $\begin{array}{l}\text { page } 2-13 \text { section } 2.4 .8 \text { line } 29 \text { "...the 0perating } \\
\text { Gallery -SWP loby and the access hallway." "The } \\
\text { area is partitioned into two sections with a large } \\
\text { access door contained in the partition, the } \\
\text { Cold...." }\end{array}$ & & $\begin{array}{l}\text { Text changed to read "...the Operating } \\
\text { Gallery and the access hallway." "The area } \\
\text { is partitioned into two sections with a } \\
\text { large access door contained in the } \\
\text { partition, the cold....". }\end{array}$ & \\
\hline 31 & $\begin{array}{l}\text { page } 2-13 \text { section } 2.4 .8 \text { line } 37 \text { : "plastic sheet used } \\
\text { to cover the floop at times of cleaning of equipment } \\
\text { to prevent contamination prior to maintenance..." }\end{array}$ & & $\begin{array}{l}\text { Text changed to read "plastic sheet used to } \\
\text { cover equipment to prevent contamination } \\
\text { prior to maintenance..." }\end{array}$ & \\
\hline 32 & $\begin{array}{l}\text { page } 2-13 \text { section } 2.4 .9 \text { line } 50: \text { "...move to the } \\
\text { Manipulator Repair shop on a transfer cart via the } \\
\text { elevator." }\end{array}$ & & $\begin{array}{l}\text { Text now reads "Decontaminated manipulators } \\
\text { are placed on a transfer cart and taken by } \\
\text { the elevator to the Manipulator Repair Shop. }\end{array}$ & \\
\hline 33 & $\begin{array}{l}\text { page } 2-14 \text { section } 2.4 .101 \text { ine } 16: \text { add } \mathrm{mm} \text { for the } 16 \\
\text { gauge and } 14 \text { gauge }\end{array}$ & & $\begin{array}{l}\text { Gauge is not going to show conversion to } \\
\text { metrics. }\end{array}$ & \\
\hline
\end{tabular}




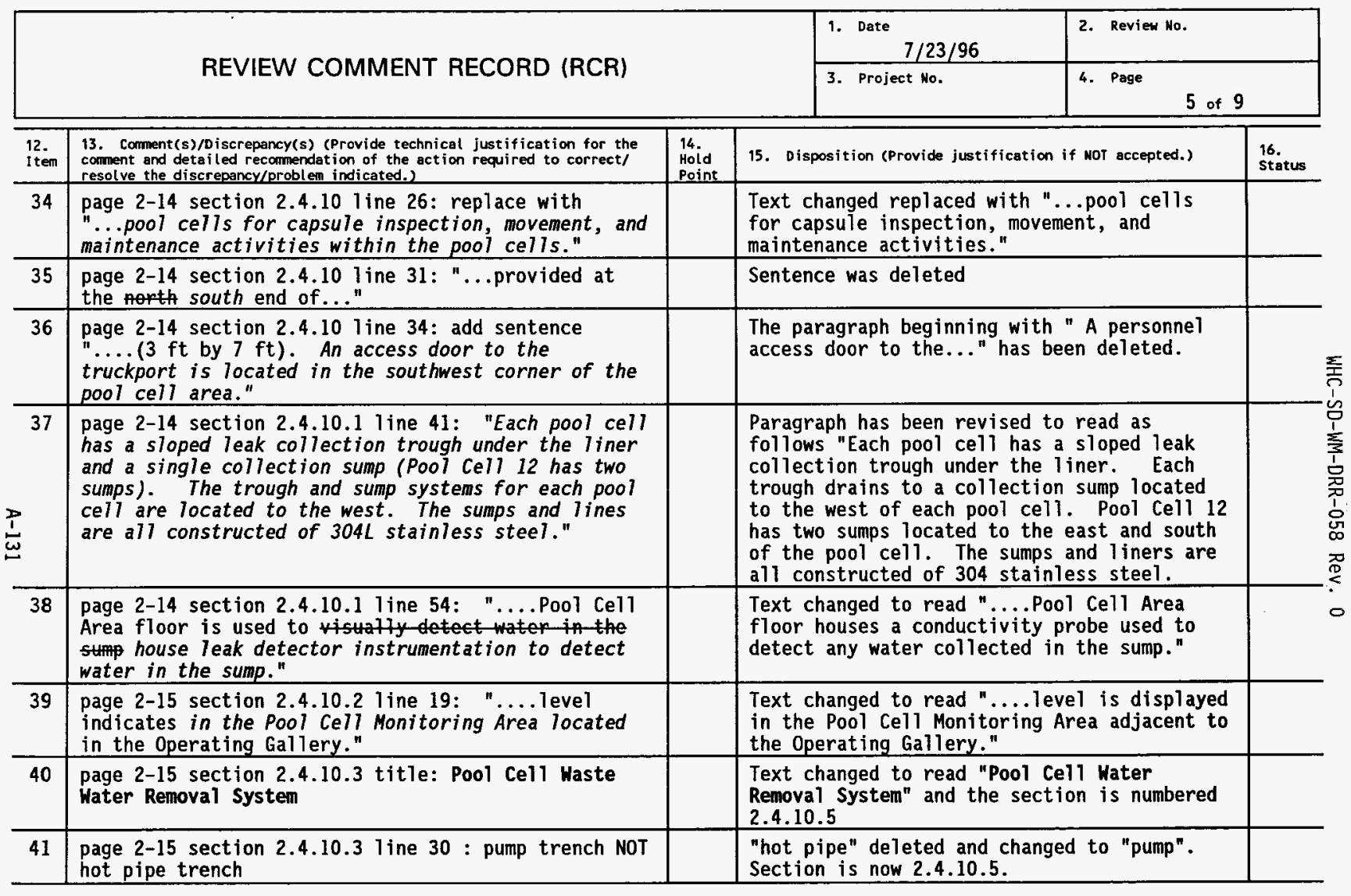




\begin{tabular}{|l|l|l|}
\hline \multirow{2}{*}{ REVIEW COMMENT RECORD (RCR) } & 3. Date $7 / 23 / 96$ & 2. Review Mo. \\
\cline { 2 - 4 } & 3. Project No. & 4 . Page \\
\hline
\end{tabular}

\begin{tabular}{|c|c|c|c|c|}
\hline $\begin{array}{l}12 . \\
\text { Item }\end{array}$ & $\begin{array}{l}\text { 13. Comment(s)/Discrepancy(s) (Provide technical justification for the } \\
\text { comment and detailed recommendation of the action required to correct/ } \\
\text { resolve the discrepancy/problem indicated.) }\end{array}$ & $\begin{array}{l}\text { 14. } \\
\text { Hoid } \\
\text { Point }\end{array}$ & 15. Disposition (Provide justification if NOT accepted.) & $\begin{array}{l}16 . \\
\text { Status }\end{array}$ \\
\hline 42 & $\begin{array}{l}\text { page } 2-15 \text { section } 2.4 .10 .3 \text { line } 34: \text { "... water to } \\
\text { the low level waste-drains liquid waste system } \\
\text { piping to Tank } 39-1 \text { located in B Plant." line } 40 \text { : } \\
\text { "...low level waste drain pipes are system piping is } \\
\text { located..." line } 41 \text { delete "An inactive } \\
\text { conductivity probe...tunnel." }\end{array}$ & & $\begin{array}{l}\text { Text changed to read ".... water to the low } \\
\text { level liquid waste system piping to Tank } 39- \\
1 \text { located in B Plant." and line } 40 \text { to read } \\
\text { "... low level waste system piping is } \\
\text { located..." and deleted the sentence "A } \\
\text { conductivity probe...tunnel. " Section is } \\
\text { now numbered } 2.4 .10 .5 \text {. }\end{array}$ & \\
\hline 43 & $\begin{array}{l}\text { page 2-15 section 2.4.12 line 55: "A personnel door } \\
\text { and two truck doors (bifold and rollup)...outside" }\end{array}$ & & $\begin{array}{l}\text { Text changed to read "A personnel door and } \\
\text { two truck doors (bifold and } \\
\text { rollup)...outside" }\end{array}$ & \\
\hline 44 & $\begin{array}{l}\text { page 2-16 section } 2.5 .1 \text { 1ine } 21: \text { " } \text {...approved by } \\
\text { DOE and/or the Nuclear.... (NRC)." line 28: "...cask } \\
\text { using the manipulators and in-cell hoist." line 30: } \\
\text { "... scrubbing consists of a mechanical scrub tank } \\
\text { supplied with decontamination solution } \\
\text { (trisodiumphosphate) and rinse with deionized } \\
\text { water." }\end{array}$ & & $\begin{array}{l}\text { Text changed to read "...approved by } D O E \\
\text { and/or the Nuclear.... (NRC)." line 28: } \\
\text { "..cask using the manipulators and in-cell } \\
\text { hoist." line } 30: \text { "...scrubbing consists of } \\
\text { a mechanical scrub tank supplied with } \\
\text { decontamination solution } \\
\text { (trisodiumphosphate) and rinse with } \\
\text { deionized water." }\end{array}$ & \\
\hline 45 & $\begin{array}{l}\text { page } 2-16 \text { section } 2.5 .2 \text { line } 36: \text { "Capsules are } \\
\text { visually examined...gauge. An inner...al so } \\
\text { performed pertinent to ensure that the inner capsule } \\
\text { has not bulged against the inside of the outer } \\
\text { capsule. A smear test is performed to ensure there } \\
\text { is no radiological contamination present prior to } \\
\text { transfer from G Cell to the pool cells." }\end{array}$ & & $\begin{array}{l}\text { Text changed to read "Capsules are visually } \\
\text { examined...gauge to ensure the outer capsule } \\
\text { has not bulged. An inner....al so performed } \\
\text { to ensure the inner capsule has not bulged } \\
\text { against the inside of the outer capsule. A } \\
\text { smear test is performed to ensure there is } \\
\text { no radiological contamination present prior } \\
\text { to transfer from } G \text { Cell to the pool cells." }\end{array}$ & \\
\hline 46 & $\begin{array}{l}\text { page } 2-16 \text { section } 2.5 .3 \text { line } 50: \text { "The capsule } \\
\text { transfer chute...12. The capsule...12 with an } \\
\text { underwater tong assembly to the assigned pool cell." }\end{array}$ & & $\begin{array}{l}\text { Text changed to read "The capsule transfer } \\
\text { chute...12. The capsule...12 with an } \\
\text { underwater tong assembly, through the } \\
\text { transfer port to the assigned pool cell." }\end{array}$ & \\
\hline
\end{tabular}




\begin{tabular}{|c|c|c|c|c|}
\hline \multirow{2}{*}{\multicolumn{3}{|c|}{ REVIEW COMMENT RECORD (RCR) }} & \multirow{2}{*}{$7 / 23 / 96$} & 2. Review Mo. \\
\hline & & & & 7 of 9 \\
\hline $\begin{array}{l}\text { 12. } \\
\text { Item }\end{array}$ & $\begin{array}{l}\text { 13. Comment( }(s) / D \text { iscrepancy(s) (Provide technical justification for the } \\
\text { comment and detailed recommendation of the action required to correct/ } \\
\text { resolve the discrepancy/problem indicated.) }\end{array}$ & $\begin{array}{l}14 . \\
\text { Hoold } \\
\text { Point }\end{array}$ & 15. Disposition (Provide justification if NOT accepted.) & $\begin{array}{l}16 . \\
\text { Status }\end{array}$ \\
\hline 47 & $\begin{array}{l}\text { page 2-17 line 1: "....serial number containing the } \\
\text { alpha designation end in the up position." line } 6: \\
\text { a recirculation pump 1ine } 7: \text { spiral heat exchanger }\end{array}$ & & $\begin{array}{l}\text { Text changed to read ".... with the end } \\
\text { containing the alpha designation and the } \\
\text { serial number in the up position." and line } \\
6 \text { to read "...a recirculation pump.." and } \\
\text { line } 7 \text { to read "...spiral heat exchanger... }\end{array}$ & \\
\hline 48 & $\begin{array}{l}\text { page 2-17 line 24: "...returned to the same pool } \\
\text { cell." }\end{array}$ & & $\begin{array}{l}\text { Text changed to read"... returned to the same } \\
\text { pool ce11." }\end{array}$ & \\
\hline 49 & $\begin{array}{l}\text { page } 2-17 \text { section } 2.5 .3 .2 \text { line } 37: \text { "...capsules } \\
\text { that do not meet storage pool criteria have a risk } \\
\text { of leakage. } 1 \text { ine } 49: \text { last sentence doesn't belong, } \\
\text { delete "In addition....facility." }\end{array}$ & & $\begin{array}{l}\text { Text changed to read "...capsules that do } \\
\text { not meet storage pool criteria." and deleted } \\
\text { the paragraph beginning with "an assessment } \\
\text { of fire hazards....." }\end{array}$ & \\
\hline 50 & $\begin{array}{l}\text { page } 2-18 \text { section } 2.5 .4 .1 \text { line } 13: \text { "No high } \\
\text { activity radioactive...manner." }\end{array}$ & & $\begin{array}{l}\text { Text changed to read "No high activity } \\
\text { radioactive... manner." }\end{array}$ & \\
\hline 51 & page 2-18 define "high activity" as used here & & "High activity" is deleted from the text. & \\
\hline 52 & $\begin{array}{l}\text { page } 2-18 \text { section } 2.5 .4 .2 \text { para } 3 \text { lines } 26 \text { through } \\
33: \text { "The A Cell....procedure are met. Before the } \\
\text { waste is loaded, the radiation level are measured. } \\
\text { The drum is the remotely sealed and raised into the } \\
\text { shielded waste cask by the cask hoist. The cask is } \\
\text { then transported by canyon crane to...... reuse." }\end{array}$ & & $\begin{array}{l}\text { Text changed to read "The A } \\
\text { Cell.....procedure } 1 \text { imits are met. Deleted } \\
\text { the sentence "Before the waste is loaded, } \\
\text { the radiation level is measured." Revised } \\
\text { sentence \#3 to read "The drum is then } \\
\text { remotely sealed and raised into the shielded } \\
\text { waste cask by the cask hoist. Deleted } \\
\text { sentence \#4 and revised sentence \#5 to read } \\
\text { "The cask is then transported by canyon } \\
\text { crane to....... interim storage site." }\end{array}$ & \\
\hline 53 & $\begin{array}{l}\text { page } 2-22 \text { section } 2.6 .2 .2 \text { line } 24: \text { "...TK-100 } \\
\text { collects liquid waste effluent from the following } \\
\text { sources by gravity drain:" }\end{array}$ & & $\begin{array}{l}\text { Section } 2.6 .3 .2 \text { text is changed to read " } \\
\text { the liquid waste effluents flow into the } \\
\text { tank, by gravity drain, from the following } \\
\text { sources" }\end{array}$ & \\
\hline
\end{tabular}




\begin{tabular}{|l|l|l|l|}
\hline \multirow{2}{*}{ REVIEW COMMENT RECORD (RCR) } & $\begin{array}{l}\text { 1. Date Review No. } \\
7 / 23 / 96\end{array}$ \\
\cline { 2 - 3 } & $\begin{array}{l}\text { 3. Project No. } \\
\text { 4. Page }\end{array}$ \\
\hline
\end{tabular}

\begin{tabular}{|c|c|c|c|c|}
\hline $\begin{array}{l}\text { 12. } \\
\text { Iten }\end{array}$ & $\begin{array}{l}\text { 13. Comment(s)/Discrepancy(s) (Provide technical justification for the } \\
\text { comment and detailed recommendation of the action required to correct/ } \\
\text { resolve the discrepancy/problem indicated.) }\end{array}$ & $\begin{array}{l}\text { Mu. } \\
\text { Hoid } \\
\text { Point }\end{array}$ & 15. Disposition (Provide justification if NOT accepted.) & $\begin{array}{l}16 . \\
\text { status }\end{array}$ \\
\hline 54 & $\begin{array}{l}\text { page } 2-22 \text { section } 2.6 .2 .2 \text { bullets: delete bullet } \# 1 \text {; } \\
\text { add "drains" to bullet \#3, separate out bullet } 6 \text { (K- } \\
3 \text { filter pit), } 7 \text { (K-3 filter unit sumps), } 10 \text { (TK-50 } \\
\text { cooling water pit) and put under heading "TK-100 } \\
\text { collects liquid waste effluents which are jetted } \\
\text { from the following sources" }\end{array}$ & & $\begin{array}{l}\text { Section } 2.6 .3 .2 \text { changed and the list now } \\
\text { reads: } \\
\text { AMU tanks and floor drains } \\
\text { Personnel decontamination room sink and } \\
\text { shower } \\
\text { Transmitter rooms } \\
\text { Exhaust Stack } \\
\text { K-1 exhaust filter building floor drains } \\
\text { K-3 filter pits } \\
\text { K-3 filter unit sumps } \\
\text { Hot Manipulator Shop floor drains } \\
\text { Canyon decontamination sink } \\
\text { TK-50 cooling water pit drains } \\
\text { Crane maintenance platform floor drains } \\
\text { Operating Gallery floor drains } \\
\text { Service Gallery floor drains } \\
\text { Truckport drain } \\
\text { Cold Manipulator Shop floor drains } \\
\text { Canyon floor drains } \\
\text { Manipulator Repair Shop floor drains }\end{array}$ & \\
\hline 55 & $\begin{array}{l}\text { page } 2-25 \text { section } 2.7 .2 .3 \text { line } 14: \text { replace first } \\
\text { sentence of section with "Selected areas of WESF } \\
\text { (not including the canyon and Pool Cell Area) are } \\
\text { protected with a wet pipe automatic sprinkler system } \\
\text { which alarms, when activated, directly to the } \\
\text { Hanford Fire Department." }\end{array}$ & & $\begin{array}{l}\text { This section has been completely revised and } \\
\text { now consists of only } 2 \text { sentences as follows, } \\
\text { "The HVAC Room, Operating Gallery, Service } \\
\text { Gallery and AMU Area are protected with a } \\
\text { wet pipe automatic sprinkler system which } \\
\text { alarms, when activated, directly to the } \\
\text { Hanford Fire Department (HFD). Portable } \\
\text { fire extinguishers are located in the } \\
\text { building in accordance with code practice. }\end{array}$ & \\
\hline 56 & $\begin{array}{l}\text { page } 2-25 \text { section } 2.7 .2 .4 \text { line } 35: \text { "...each hot } \\
\text { cel1 which alarm within the building and directly to } \\
\text { the HFD." }\end{array}$ & & $\begin{array}{l}\text { Text changed to read "...each hot cell which } \\
\text { alarms within the building and directly to } \\
\text { the HFD." }\end{array}$ & \\
\hline
\end{tabular}




\begin{tabular}{|l|l|}
\hline 1. Date $7 / 23 / 96$ & 2. Review No. \\
\hline 3. Project Ho. & 4. Page 9 of 9 \\
\hline
\end{tabular}

\begin{tabular}{|c|c|c|c|c|}
\hline $\begin{array}{l}\text { 12. } \\
\text { Item }\end{array}$ & $\begin{array}{l}\text { 13. Comment(s)/Discrepancy(s) (Provide technical justification for the } \\
\text { corment and detailed recommendation of the action required to correct/ } \\
\text { resolve the discrepancy/problem indicated.) }\end{array}$ & $\begin{array}{l}14 . \\
\text { Hoid } \\
\text { Point }\end{array}$ & 15. Disposition (Provide justification if NOT accepted.) & $\begin{array}{l}16 . \\
\text { Status }\end{array}$ \\
\hline 57 & $\begin{array}{l}\text { page } 3-26 \text { section } 2.7 .3 \text { is confusing and only covers } \\
\text { some of the rad detections systems }\end{array}$ & & $\begin{array}{l}2.7 .3 \text { has been revised extensively, please } \\
\text { see current version. }\end{array}$ & \\
\hline 58 & $\begin{array}{l}\text { page } 2-28 \text { section } 2.8 .2 \text { line } 26: \text { Mentioning the } \mathrm{K}-3 \\
\text { bubblers here seems out of place - if it is } \\
\text { mentioned here then other systems should be } \\
\text { mentioned as well. }\end{array}$ & & $\begin{array}{l}2.8 .2 \text { has been totally revised, please see } \\
\text { current version. }\end{array}$ & \\
\hline 59 & $\begin{array}{l}\text { page } 2-28 \text { section } 2.8 .3 \text { line } 38: \text { "Another } 100 \text { psig } \\
\text { reducing station...." line } 44: \text { "...supplied to the } \\
\text { pool cell water removal system by a steam jet that } \\
\text { is used...." }\end{array}$ & & $\begin{array}{l}\text { Text changed to read "Another } 100 \text { psig } \\
\text { reducing station...." line } 44: \\
\text { "...supplied to the pool cel1 water removal } \\
\text { system by a steam jet that is used...." }\end{array}$ & \\
\hline 60 & page $2-30$ there are two section $2 \cdot 8 \cdot 4 \cdot 3.3$ & & $\begin{array}{l}\text { Changed second section } 2 \cdot 8 \cdot 4 \cdot 3 \cdot 3 \text {. to } \\
2.8 .4 .3 .4 \text {. }\end{array}$ & \\
\hline 61 & $\begin{array}{l}\text { page } 2-30 \text { lst section } 2.8 .4 .3 .3 \text { line } 30: \text { cooling } \\
\text { water drain system was called B Plant process sewer } \\
\text { earlier in the chapter }\end{array}$ & & $\begin{array}{l}\text { "Cooling Water Drain system" is changed to } \\
\text { read "Low Level Waste System". }\end{array}$ & \\
\hline 62 & $\begin{array}{l}\text { page } 2-30 \text { 2nd section } 2.8,4.3 .3 \text { line } 36: \text { "...raw } \\
\text { water pressure to WESF.." }\end{array}$ & & $\begin{array}{l}\text { Text changed to read "... raw water pressure } \\
\text { to WESF..." }\end{array}$ & \\
\hline 63 & $\begin{array}{l}\text { page } 2-31 \text { section } 2.9 \text { bullets: Bullet } 14 \text { add trailer } \\
\text { at the end, bullet } 15 \text { replace wing with trailer, } \\
\text { what is the solid radioactive waste system and why } \\
\text { pick this system and not others? }\end{array}$ & & $\begin{array}{l}\text { "Office Wing" changed to "Office Trailer." } \\
\text { "Laundry Storage" changed to "Laundry } \\
\text { Storage Trailer" } \\
\text { "Solid Radioactive Waste System" has been } \\
\text { deleted. }\end{array}$ & \\
\hline 64 & $\begin{array}{l}\text { page 2-31 section } 2.9 .1 \text { line } 46: \text { "... operations and } \\
\text { accumulated } 7 \text { iquids in the sump..." At the end of } \\
\text { the section add "The TK-100 pit contains a sump with } \\
\text { alarm capabilities. The sump can be jetted to the } \\
\text { tank to remove accumulated liquid." }\end{array}$ & & $\begin{array}{l}\text { Text changed to read "...operations and } \\
\text { accumulated liquids in the sump..." At the } \\
\text { end of the section add "The TK- } 100 \text { pit } \\
\text { contains a sump with alarm capabilities. } \\
\text { The sump can be jetted to the tank to remove } \\
\text { accumulated liquid." }\end{array}$ & \\
\hline 65 & $\begin{array}{l}\text { page 2-32 section } 2.9 .4 \text { line } 36: \text { "... System } \\
\text { Receiver Tank and the primary dryer. }\end{array}$ & & $\begin{array}{l}\text { Text changed to read "...system receiver } \\
\text { tank and the primary dryer." }\end{array}$ & \\
\hline
\end{tabular}




- puepue7s

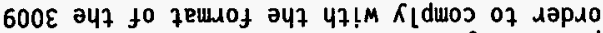
u! әлау pa!f!quap! әq of spaəu 7 ! $\kappa$ !sno!nadd pəssnos!p uәəq sey $7 !$ y6noy 7 Uana pue แa7sरs

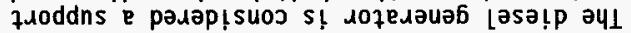
-adojs gSI pue uo!fग!ps!un! ISJM 247 $4 ! 47 ! M$

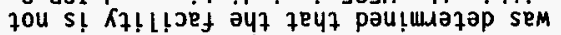

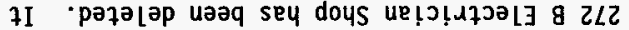

saz!s

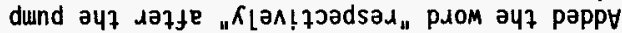

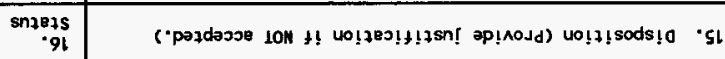

PloH
71

\begin{tabular}{|c|c|}
\hline 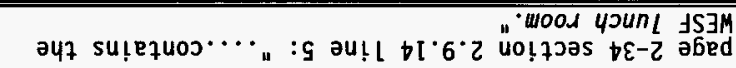 & 69 \\
\hline 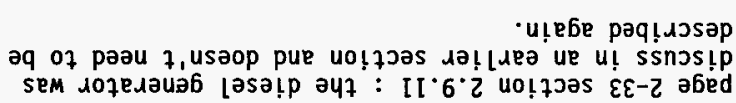 & 89 \\
\hline 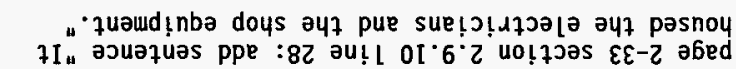 & $\angle 9$ \\
\hline 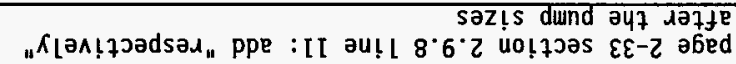 & 99 \\
\hline 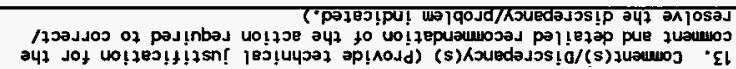 & $\begin{array}{r}4=31 \\
-21\end{array}$ \\
\hline
\end{tabular}

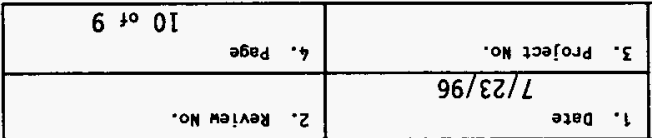


WHC-SD-WM-ORR-058 Rev. 0

APPENDIX B

Closed Senior Analyst Advisory Group (SAAG) Review RCRs 
WHC-SD-WM-DRR-058 Rev. 0

This page intentionally left blank. 


\section{CORRESPONDENCE DISTRIBUTION COVERSHEET}

Author

SA\&NE Senior Analysts Advisory Group
Addressee

Distribution
Correspondence No.

8M000-SAAG-96006

subject: SAAG MEETING MINUTES ON DISCUSSION OF THE WASTE ENCAPSULATION STORAGE FACILITY INTERIM SAFETY BASIS ACCIDENT SELECTION METHODOLOGY

INTERNAL DISTRIBUTION

\begin{tabular}{|c|c|c|c|c|}
\hline Approval & Date & Name & Location & W/att \\
\hline & & R. D. Crowe & $\mathrm{HO}-38$ & \\
\hline & & E. P. DiVincenzo & A3-37 & \\
\hline & & J. P. Estrellado, Jr. & T3-01 & \\
\hline & & H. J. Goldberg & $\mathrm{HO}-35$ & \\
\hline & & J. Greenborg & Ho-35 & \\
\hline & & B. E. Hey & $A 3-34$ & \\
\hline & & L. E. Johnson & $A 2-25$ & \\
\hline & & D. S. Leach & A3-34 & \\
\hline & & R. M. Marusich & $A 3-34$ & \\
\hline & & R. P. Omberg & $R 3-85$ & \\
\hline & & D. R. Porten & $A 2-26$ & \\
\hline & & A. L. Ramble & $A 3-38$ & \\
\hline & & J. E. Shapley & $A 2-25$ & \\
\hline & & R. L. Simons & $\mathrm{HO}-35$ & \\
\hline & & D. A. Smith & $A 2-25$ & \\
\hline & & A. E. Waltar & HO-32 & \\
\hline & & A. B. Webb & A3-37 & \\
\hline
\end{tabular}




\section{Westinghouse

From: $\quad$ SA\&NE Senior Analysts Advisory Group

Phone: $376-5116$ A3-34

Date: April 24, 1996

Subject: SAAG MEETING MINUTES ON DISCUSSION OF THE WASTE ENCAPSULATION STORAGE FACILITY INTERIM SAFETY BASIS ACCIDENT SELECTION METHODOLOGY

To: Distribution

$$
\begin{aligned}
& \text { cc: LB File A3-34 } \\
& { }^{\star} \mathrm{CC} \text { :mail and hard copy }
\end{aligned}
$$

The Senior Analysts Advisory Group (SAAG) met on February 2, 1996 to review the accident selection methodology for the Waste Encapsulation Storage Facility (WESF) Interim Safety Basis (ISB). Those in attendance were:

$\begin{array}{lllll}\text { Craig Carro } & \text { Ralph Crowe } & \text { Brett Hall } & \text { Brit Hey } & \text { Larry Johnson } \\ \text { Mark Medsker } & \text { Bob Marusich } & \text { Don Porten } & \text { Dean Smith } & \text { Brian Vonderfecht }\end{array}$

The WESF ISB accident selection methodology was presented to the SAAG for a preliminary review prior to incorporation into the ISB. Mark Medsker of H\&R Technical Associates made the presentation.

The WESF ISB accident selection methodology was depicted by a three-by-three likelihood and consequence ranking matrix. Frequency along the vertical axis consisted of the standard categories: Anticipated, Unlikely, and Extremely Unlikely. Severity of consequences was displayed along the horizontal axis.

Accident types identified for further analysis were:
1. Loss of Pool Water
2. Loss of Capsule Integrity
3. Facility Fire
4. Hydrogen Generation and Deflagration
5. Loss of Confinement
6. Natural Phenomena
7. External Events
8. Dropped Object Impact

The one major comment identified by the SAAG members was that discrete frequencies were not determined for events used in this analysis.

Safety Analysis \& Nuclear Engineering

Senior Analysts Advisory Group

gjr 


\section{CORRESPONDENCE DISTRIBUTION COVERSHEET}

Author
SA\&NE Senior Analysts Advisory Group Adressee


From: $\quad$ SA\&NE Senior Analysts Advisory Group

Phone: $376-5116$ A3-34

Date: $\quad$ February 4, 1996

Subject: SAAG MEETING MINUTES ON DISCUSSION OF WORK PLAN FOR SAFETY ANALYSIS OF WESF ISB

To: Distribution

$$
\begin{aligned}
& \text { Cc: SAAG LB } 34 \\
& \text { *CC:mail and hard copy (w/o attachments) }
\end{aligned}
$$

The Senior Analysts Advisory Group (SAAG) met on January 18, 1996 to discuss the subject document. Those in attendance were:

Brit Hey Maryanne Kummerer Dirk Leach Porten

The subject document was presented by Mr. Hey. The purpose of the work plan for preparation of safety analyses in support of the Waste Encapsulation and Storage Facility (WESF) Interim Safety Basis (ISB) was to 1) provide input into the overall WESF ISB project plan, 2) provide the SA\&NE Senior Analysts Advisory Group an opportunity to review the project, 3) inform management, WESF staff, Independent Safety, and other analysts of the direction and status of the effort, and 4) provide basic assumptions for use by safety analysts in preparation of the ISB. Comments identified by the SAAG members are listed below.

1. In Section 3.1 under Chapter 3, the work plan outlined the intent to establish Final Hazard Categorization based on the potential for offsite consequences. It was recommended that the final hazard categorization, per DOE-STD-1027-92, should be based on an unmitigated release of available hazardous material which is meant to consider material quantity, form, location, dispersibility, and interaction with available energy sources. It was also recommended that if materials at risk exceed Hazard Category 2 limits by substantial amounts, a statement emphasizing that the PSO will review the category determination will be added.

2. On page 4, it was suggested that the phrase "Due to the classified nature of sabotage and terrorism" be rephrased to convey that the subject is covered by a security plan.

This concludes the list of comments deemed by the SAAG to have a general application to the SA\&NE department. Additional detail comments were provided by individual SAAG members via $c c$ :mail and are attached.

Safety Analysis \& Nuclear Engineering

Senior Analysts Advisory Group

Attachments 2 
WHC-SD-WM-DRR-058 Rev. 0

8M400-SAAG-96002

ATTACHMENT 1

Page 1 of 2

[113] From: Dean A Smith at -BCS78 1/17/96 2:27PM (3291 bytes: 1 In)

To: Brit E Hey

cc: Maryanne Kummerer, Dirk S Leach, Robert M Marusich, Donald R Porten at BCS4, Dean A Smith

Subject: Review of WESF Work Plan

Message Contents

Text item 1: Text_1

Attached are comments from review of WESF ISB Work Plan.

1. The plan should reference the Implementation Plan for DOE 5480.23

and explain any differences with the Implementation Plan.

2. Section 2.1, Item 3 . Chapter 3 is identified twice. The second instance should refer to Chapter 4 .

3. Section 2.2.1. The last paragraph refers to the classified nature of sabotage and terrorism. These are not classified and it is not apparent that discussion of these activities is classified under current rules. other safety documents have stated that these activities are not included in the scope of the safety documentation since they are addressed in the facility security plan.

4. Section 2.2.2 last sentence of third paragraph. The river does not have to be viewed as the location of the public and is not in some safety documents. As noted in the following paragraph, consideration could be given to using the fence 1 ine as the boundary. The $40 \%$ difference seems large for a $200 E$ facility. Providing the fence $l$ ine $X / Q$ would be helpful.

5. Section 3.3.1.2. This section states that technique likely to be MLD will be discussed in this section and states that draft section is complete. Does draft discuss MLD?

6. Section 3.4 Introduction states that accident analysis is to identify safety class features and TSRs for protection of the public. The accident analysis should also address safety class features and TSRs for protection of the on-site workers. It is not likely that accident analysis will be performed for each hazard that could have on-site or off-site impact or address each barrier which may be required for protection of the on-site worker or the public. As noted in section 3.4.2, the section will analyze DBAs for each major category and will require identification of representative and bounding accident scenarios. 
8M400-SAAG-96002

ATTACHMENT 1

Page 2 of 2

I suggest that the plan make it clear that the accident analysis will not address the safety classification of each barrier. The hazard category of individual barriers not addressed in the accident analys is will need to be evaluated in the Hazards Evaluation (or in Chapter 4).

7. Section 3.4.2. The second paragraph refers to Section 3.2. I believe it should refer to 3.3 .

8. Section 3.4.2.x.5. The second paragraph indicates that preparatory efforts are not expected to be significant. This seems inconsistent with Section 3.4.2.x.2. I suspect preparation could be significant for those that are controversial. 
8M400-SAAG-96002

ATTACHMENT 2

Page 1 of 2

[111] From: Robert M Marusich at BCS78 1/16/96 3:49PM (4769 bytes: 92 In) To: Brit E Hey

cc: Maryanne Kummerer, Dirk S Leach, Robert M Marusich, Donald R Porten at -BCS4, Alan L Ramble at "WHC85, Dean A Smith

Subject: RE: RE: Comments on the WSEF ISB PIan

Message Contents

Brit's Reply to Bob M.'s original Comments----

Bob, I briefly respond to your comments. I think \#2 is a result of a misunderstanding.

Brit

-Bob M.'s Original Comments-

1. page 3, Section 2.2.1 - Besure to describe the condition of the capsules recieved (intact, or leaky?) Why is the electro-polisher excluded? I was under the imnpression that they were going to use this. Describe the decon techniques allowed.

Response: The ISB will cover the receipt or the discovery of

a leaking capsule. It will not, however, describe the conditions of received capsules since that information will not be known. Electro-polisher will not be used. Scrubber will be described.

2. page 4, Section 2.2.1 - The phrase "....include, but are not 1 imited to..." defeats the purpose of the ISB. Fro USQ screenings what is needed is "Operations covered by this ISB are ..." followed by a definative list of operations.

You are getting quite broad and outside the scope of the existing SAR's when you allow re-packaging, alternative means of capsule disposal, D\&D, etc. List only what is necessary to cover.

Response: I think you misunderstood. These are operations specifically NOT allowed.

3. page 4, Section 2.2.2. Line 1 - I did not think that the ISB needs to provide a toaally new authorization basis. The SAR is reasonably good and should only need minor upgrades (except if pool drain is credible). If new operations must be covered, I believe the ISB is an inappropriate place to cover these. These should be covered in a SAR update.

Response: The SAR is not reasonably good. It is very bad. We are starting over. As far as Chapters 2, 3, 4, and 5, we are doing the SAR update now. 
WHC-SD-WM-DRR-058 Rev. 0

8M400-SAAG 96002

ATTACHMENT 2

Page 2 of 2

4. page 17, Section 3. third line from the bottom - Do you mean H\&R, not FAI? If not, you mean the FAI will help with the consequences and controls or just controls.

Response: I mean FAI. Yes, FAI is helping with consequences, source term specifically.

5. Section 3.3.2.3, para 2, page 19 - A master Logic Diagram is overkill for a Hazard Evaluation. Typically only qualitative (words) arguements are used to bin accidents.

Response: I don't think H\&R is going to use a MLD anyway.

paragraph 4 - Instead of dismissing the industrial accidents, why not bundle them up and give them to WESF.

Response: Industrial accidents not within our scope. We choose to divert resources to radiological accidents. HESF already knows about these industrial accidents from HAZOPS and common sense.

6. page 26 - With the coverblocks off, H2 in the capsule storage area should not be a concern.

Response: $\mathrm{H} 2$ is still being generated (approx. 3.4 CFM) and must be addressed some how. PNNL is tasked with looking at that.

Bob Marusich

Thanks for your comments Bob. 


\section{CORRESPONDENCE DISTRIBUTION COVERSHEET}

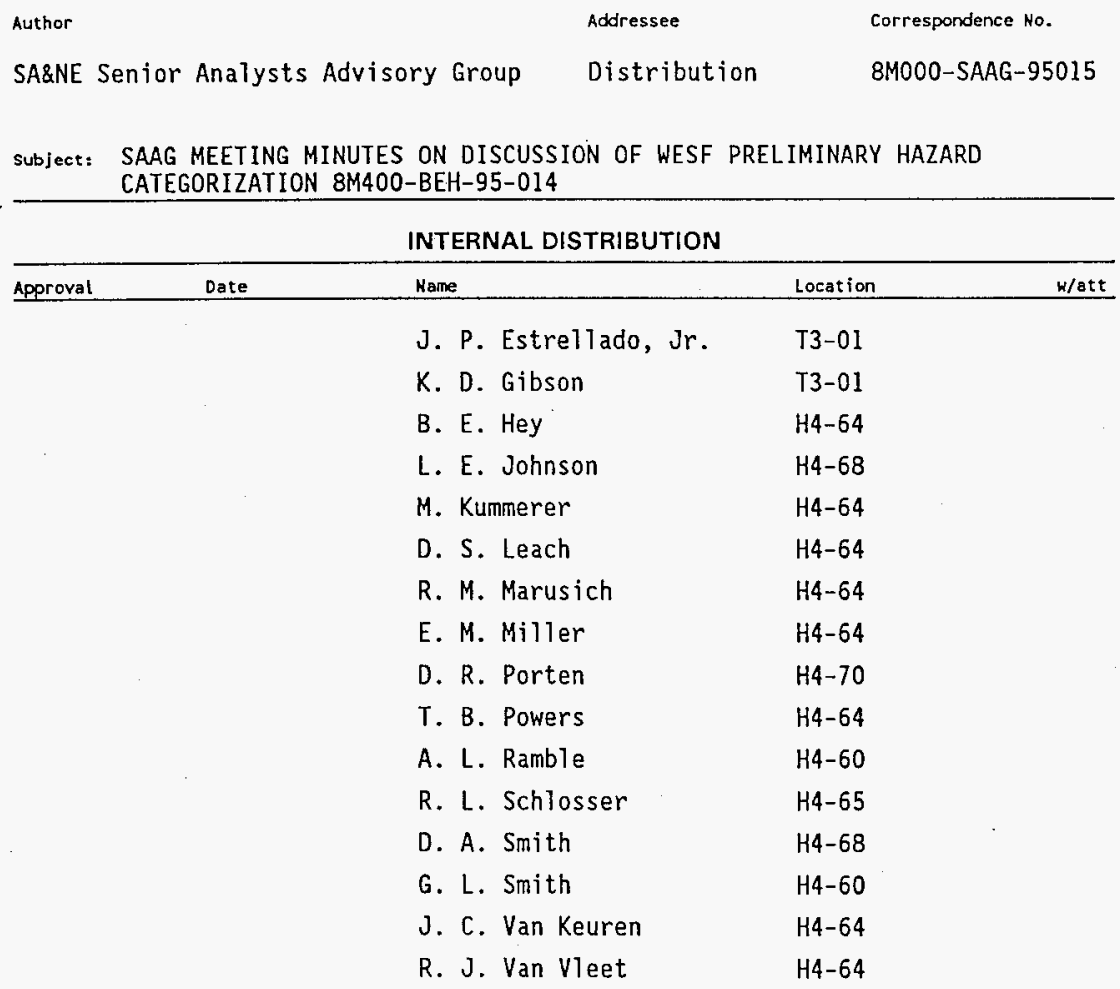


From: $\quad$ SA\&NE Senior Analysts Advisory Group

Phone: $\quad 376-5116$ A3-34

Date: November 7, 1995

Subject: SAAG MEETING MINUTES ON DISCUSSION OF WESF PRELIMINARY HAZARD

CATEGORIZATION 8M400-BEH-95-014

To: Distribution ( $W / 0$ attachment*)

CC: SAAG File/LB A3-34

*CC:mail and hard copy

The Senior Analysts Advisory Group (SAAG) met on October 16, 1995 to discuss the subject document. Those in attendance were:

Brit Hey Dirk Leach Dean Smith Maryanne Kummerer

The subject evaluation was authored and presented by Mr. Brit E. Hey and provided an initial Hazard Category screening per the guidance provided in DOE-STD-1027-92. This was accomplished by comparing the inventory of various Waste Encapsulation and Storage Facility (WESF) location inventories to the Category 2 threshold limits. As expected, the capsule inventory exceeded the limit and WESF is thus preliminarily classified $\mathrm{HC}-2$. There was some discussion on segmentation of WESF inventories separate from $\mathrm{B} \mathrm{Plant.}$ In order to avoid confusion, a statement was added to explicitiy state that the B Plant inventories were excluded from consideration in the WESF hazard categorization. 0ther comments made during the review process are attached for documentation purposes.

Review time for this task was charged to KB4C5.

Safety Analysis \& Nuclear Engineering

Senior Analysts Advisory Group

gjr

Attachment 


\section{ATTACHMENT}

[8] From: Robert M Marusich at WHC150 10/11/95 5:50AM (1578 bytes: 24 In)

To: Brit E Hey at -WHC188, Maryanne Kummerer at -WHC188, Dirk S Leach at

-WHC276, Robert M Marusich, Donald R Porten at -WHC276, Alan L Ramble at

-HHC276, Dean A Smith at -WHC276

Subject: Comments on the WESF Haz Cat

I have the following comments on the Hazard category for WESF.

1. There must be a table showing the comparisons of the inventory to the Threshold quantities in order to demonstrate Cat 2. To simply conclude it is Cat 2 is inappropriate.

2. Since there are no calculations and no lessoris to be learned from this analysis, why is the SAAG reviewing this document?

3. It was brought to my attention during the DOE review of the Cross-Site Transfer PSAR that while DOE-STD 3009 states that the Cat 1 is for reactors, DOE Order 5480.23 Section 8.C states that Cat 1 is for facilities that "show the potentila for significant offsite consequences". The Cross-Site Transfer PSAR had to argue that not only was the inventory above Cat 2 Quantities but that the offsite dose was not significant. I believe we need to bring that type of perspective to WESF and I asked the same question for the Tank Farms Haz Cat Calc.

Bob Marusich 
WHC-SD-WM-DRR-058 Rev. 0

8M000-SAAG-95-015

ATTACHMENT

Page 2 of 4

[10] From: Brit E hey at WHC188 10/11/95 11:33AM (4705 bytes: 83 1n)

To: Robert M Marusich at WHC150

cc: Brit E Hey, Maryanne Kummerer, Dirk S Leach at -WHC276, Donald R Porten at WHC276, Dean A Smith at -WHC276

Subject: Comments on the WESF Haz Cat

I have the following comments on the Hazard category for WESF.

1. There must be a table showing the comparisons of the inventory to the Threshold quantities in order to demonstrate Cat 2. To simply conclude it is Cat 2 is inappropriate.

Bob, Please read our procedure. There is no requirment for a table. I did not simply conclude $\mathrm{HC}-2$. A preliminary HC-2 was assigned based on a comparison of the inventory, provided in the letter in Appendix $A$ and the threshold limits which I also give. I did not conclude without reason as you imply. Brit

2. Since there are no calculations and no lessons to be learned from this analysis, why is the SAAG reviewing this document?

Bob, The SAAG Charter does require these and similar analyses to be reviewed. The fact that it is not very complicated does not negate this requirement. Brit

3. It was brought to my attention during the DOE review of the Cross-Site Transfer PSAR that while DOE-STO 3009 states that the Cat 1 is for reactors, DOE Order 5480.23 Section 8.c states that Cat 1 is for facilities that "show the potentila for significant offsite consequences". The Cross-Site Transfer PSAR had to argue that not only was the inventory above Cat 2 Quantities but that the offsite dose was not significant. I believe we need to bring that type of perspective to WESF and I asked the same question for the Tank Farms Haz Cat Calc.

Bob Marusich

Bob, The X-site Transfer PSAR is much further along than the WESF SAR upgrade. It is appropriate that the PSAR should have a better handle on the $H C$ than would be obtained from a comparison to threshold inventories. The same is true for tank farms. What Tony did was backfit a preliminary HC to the ASA because one had not been done. And you know the government, if there is anything they get picky about is out-of-order paperwork. The tank farms will recommend a final $\mathrm{HC}$ based on dose consequences, but that was not the purpose of Tony's prelim. HC. WESF on the other hand, is in the process of generating a program $\mathrm{plan}$ for the ISB. We do not know what the dose consequences will be yet. 
WHC-SD-WM-DRR-058 Rev. 0

8M000-SAAG-95-015

ATTACHMENT

Page 3 of 4

But in the meantime, we would like DOE to know what level of detail we are working to, and that is $\mathrm{HC}-2$ based on a very simple preliminary screening.

Bob,

For a preliminary Haz. Cat. (WESF), I would not go into the detailed dose calculations that would be necessary to argue the significant vs. not significant issue. Based on my interpretation of 1027, Preliminary Haz. Cat. is determined by a comparison of the inventory to the threshold quantities and 1027 does not require detailed dose calculations.

It could be argued that final HC determination needs to address the significant vs. not significant dose issue due to the definition of HC 1 contained in 5480.23. However, even this is unclear because 1027 says final HC is still done by comparison to the threshold quantities of isotopes. The only difference in 1027 between initial and final is that "inventory at risk" and "release fractions" may be better defined as a result of having completed the accident analysis.

Why are we reviewing the HC? To ensure consistency in application of 1027 and to address issues like the one you brought up in your item \#3.

Anyone else out there have any feedback?

Dirk 
[9] From: Dirk S Leach at -WHC276 10/11/95 7:41AM (2915 bytes: 52 In) To: Robert M Marusich at -WHC150, Brit E Hey at -WHC188, Maryanne Kummerer at -WHC188, Donald R Porten, Alan L. Ramble, Dean A Smith

Subject: Comments on the WESF Haz Cat

I have the following comments on the Hazard category for WESF.

1. There must be a table showing the comparisons of the inventory to the Threshold quantities in order to demonstrate Cat 2. To simply conclude it is Cat 2 is inappropriate.

2. Since there are no calculations and no lessons to be learned from this analysis, why is the SAAG reviewing this document?

3. It was brought to my attention during the DOE review of the Cross-Site Transfer PSAR that while DOE-STD 3009 states that the Cat 1 is for reactors, DOE Order 5480.23 Section 8.c states that Cat 1 is for facilities that "show the potentila for significant offsite consequences". The Cross-Site Transfer PSAR had to argue that not only was the inventory above Cat 2 Quantities but that the offsite dose was not significant. I believe we need to bring that type of perspective to WESF and I asked the same question for the Tank Farms Haz Cat Calc.

Bob Marusich

Bob,

For a preliminary Haz. Cat. (WESF), I would not go into the detailed dose calculations that would be necessary to argue the significant vs, not significant issue. Based on my interpretation of 1027, Preliminary Haz. Cat. is determined by a comparison of the inventory to the threshold quantities and 1027 does not require detailed dose calculations.

It could be argued that final HC determination needs to address the significant vs, not significant dose issue due to the definition of HC 1 contained in 5480.23. However, even this is unclear because 1027 says final $\mathrm{HC}_{\text {is }}$ istill done by comparison to the threshold quantities of isotopes. The only difference in 1027 between initial and final is that "inventory at risk" and "release fractions" may be better defined as a result of having completed the accident ana1ysis.

Why are we reviewing the $\mathrm{HC}$ ? To ensure consistency in application of 1027 and to address issues like the one you brought up in your item \#3.

Anyone else out there have any feedback?

Dirk 
WHC-SD-WM-DRR-058 Rev. 0

APPENDIX C

Closed Pacific Northwest National Laboratories Review RCRs

$C-j$ 
WHC-SD-WM-DRR-058 Rev. 0

This page intentionally left blank. 
Ms. Kathleen Jennings-Mills

Westinghouse Hanford Company

Manager, WESF Engineering

B-Plant, WESF Complex, Trailer MO-408

Richland, WA 99352

Dear Ms. Jennings-Mills:

\section{REF: PNNL REVIEW OF THE WASTE ENCAPSULATION AND STORAGE FACILITY INTERIM SAFETY BASIS ACCIDENT ANALYSIS}

PNNL has completed the review of the Waste Encapsulation and Storage Facility Interim Safety Basis (WESF ISB) Accident Analysis. All comments have been resolved to the satisfaction of the individual review team members (see Attachments 1 through 4).

It is the opinion of the review team that the WESF ISB provides a conservative and bounding analysis of postulated accidents, thus demonstrating that the WESF can be operated safely, without undue risk to the health and safety of the worker, public and the environment. The accident analysis provides the necessary information and bases to select safety systems, structures and components, and Interim Operational Safety Requirements. However, it is also the opinion of the review team that, the following should be considered during the preparation of the final safety analysis report:

The accident scenarios, as written, 'contain too much detail regarding systems design and operation. Descriptions of WESF systems and operations should be included in Chapter 2. The detailed systems descriptions required for safety class and safety significant items should be provided in Chapter 4 . The derivation and bases for the Interim Operational Safety Requirements should be included in Chapter 5. These revisions would make the accident analysis more concise and easier to use. 
Ms. Kathleen Jennings-Mills

September 17, 1996

Page 2

The accident scenarios, as written, contain a significant amount of forward and back referencing. During the preparation of the final safety analysis report, the accident analysis should be restructured to reduce the amount of forward referencing. This would make the accident analysis easier to follow.

Please call me if yoy have any questions, or if I can be of further assistance.

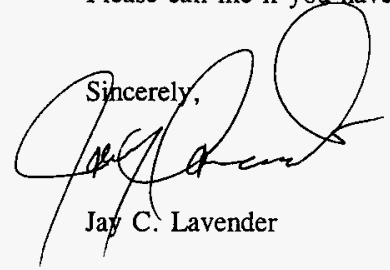

JCL:sm

Attachments 


\begin{tabular}{l|l|l|l|l}
\hline 5. Document Number(s)/Title(s) & $\begin{array}{l}\text { 6. Program/Project/ } \\
\text { Building Number }\end{array}$ & 7. Reviewer & 8. Organization/Group & 9. Location/Phone \\
WESF ISB Accident Analysis Review & Karl Bohlander & PNNL \\
\hline
\end{tabular}

17. Comment Submittal Approval:

10. Agreement with indicated comment disposition(s)

11. CLOSED

Organization Manager (Optiona!)

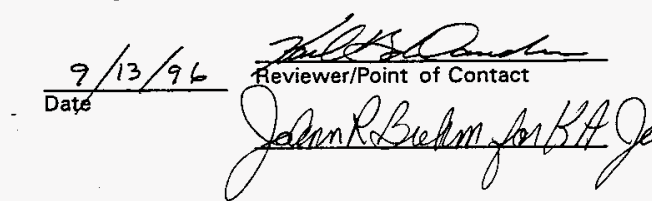

$9 / 13 / 96$ bate bate 120

Reviewer/Point of Contact

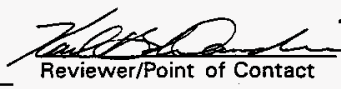
1

\begin{tabular}{|l|l|l|}
\hline THE FOLLOWING COMMENTS APPLY TO THE REVISED WESF ISB ACCIDENT \\
ANALYSIS RECEIVED JULY 24, 1996.
\end{tabular}


Section 3.3.2.3.5.1, Page 3-49, the accidents have been selected based on a highly qualitative process aimed at identifying the highest risk events. This process is acceptable if one fully understands the mechanics of the accident and the components of the risk ranking. However, this analysis is so heavily founded on judgement and estimates that selecting only the highest risk event may overlook other equally important events when uncertainty in the qualitative analysis is considered. The worst accident in commercial nuclear power li.e. Three Mile Island (TMI)] can be attributed, in part to this kind of judgement. One must also consider the potential of lesser ranked events to propagate into major upsets.

It may be appropriate to provide some additional discussion relative to lesser ranked events and their potential to propagate as part of the final accident selection.
Accepted. The highly qualitative nature of the accident selection process followed (from DOE-STD-3009-94) was recognized early in the preparation of the chapter. The selection process does cover lesser risk ranked accident sequences and their potential to propagate into larger events. The discussion in Section 3.3.2.3.5.1 has been revisited to better present the selection process. As part of this, the following summary has been added: "In summary, the accidents were selected within each category and type according to the following criteria:

Highest risk rank.

Unique accident with potential for significant consequences, regardless of risk rank.

Unique accident which challenges a particular barrier and which has the potential for significant consequences.

Unique accident which is not bounded by another accident and which has the potential for significant consequences."

Resolution accepted. 
Section 3.3.2.3.5.1, Pages $3-49$ and 3-50, the operational events or accidents are grouped by type based on physical phenomena (e.g., fires, explosions), however, several of the accidents evaluated provide no specific source term or consequence determination, instead deferring to other events such as the loss of pool cell water as providing the limiting consequence for the accident.

The accidents should be grouped by consequence and not by phenomena. This would eliminate the cross-referencing of analyses that is so prevalent in this document. This cross referencing makes it extremely difficult to determine if the accident is adequately addressed. As an example, the loss of electrical power (LOEP) accident references 1) the loss of ventilation accident, which is stated as having no significant consequence at all, 2) the hydrogen explosion accident, which in turn references the impact accident and the loss of pool water accident, and 3 / the loss of pool water accident. Following this analysis process/logic, the LOEP and the hydrogen explosion accidents are basically reduced to initiators for loss of water events. The accident analysis could be greatly simplified if the accidents were grouped by consequence, such as those resulting in loss of pool water.

As a minimum, consideration should be given to eliminating those accidents that do not have unique source terms or consequences on the basis that they are part of, or bounded by, other accidents.

Section 3.4.2.2.1.4, page 3.85, related to the comment above, this section refers the reader to Section 3.4.2.5 with regard to the consequence comparison to guidelines for the Hydrogen Explosion accident. But Section 3.4.2.5 further refers to reader to other accidents. This approach is makes the analysis very muddled, cumbersome, confusing and exasperating to evaluate.

\section{General Comment:}

Event scenario descriptions should be reduced to the step by step event progression considered by the analysis and nothing more. There is to much superfluous discussion in the scenarios.
It is recognized that the analysis depends heavily upon crossreferencing and that several of the accidents serve as initiators to other accidents. It is also recognized that other formats may present the results in a more efficient way. However, the current format is adequate for the purposes of a ISB and possible reformatting efforts will be considered if this same material is incorporated into the new facility SAR.

I would agree that this is more a format and content issue and not a technical issue. The resolution is accepted on that basis.
Accepted. Reformatting will be considered if the material is used for the facility SAR.

Resolution accepted.

Other reviewers have requested, and are pleased with, a more indepth discussion of the scenario. This broader discussion has allowed the analysis to show the postulated accident progressions in context of the'facility SSCs and operations, generally bringing the scenario into perspective.

Resolution accepted. I disagree that the scenario descriptions are merely in-depth discussions. However, I will accept the resolution of this comment since the issue is one of format and content as opposed to technical adequacy. 
\begin{tabular}{|ll}
\hline & Comment \\
\hline Section 3.4 .2 .2 .2 , page $3-86$, discusses the impacts to WESF from events at
\end{tabular} adjacent facilities. With regard to the seismic event discussion, the analysis is limited to the impacts on WESF from a $0.12 \mathrm{~g}$ earthquake, which is apparently the design basis earthquake for B-plant. The analysis should consider the Bplant impacts on WESF from a $0.25 \mathrm{~g}$ earthquake, which is the WESF design basis. The ability to re-enter WESF and control water loss will be dependent on the B-plant source term associated with the larger earthquake. Ideally, there should be a bounding DBE for the Hanford site and the facilities should be evaluated accordingly. It does not make sense, in accident space, to have multiple DBEs for the site. For example, if $0.12 \mathrm{~g}$ is the site DBE, then that should be the basis for WESF damage assessments and the $0.25 \mathrm{~g}$ WESF design provides margin, conversely, if $0.25 \mathrm{~g}$ is the site DBE, then damage to B-plant should be assessed based on an earthquake of that magnitude.

The analysis should clearly discuss the ability to regain entry to WESF following a $0.25 \mathrm{~g}$ earthquake. The discussion in this section also states that events in Bplant will not prevent the entry into the "storage area control room". Section 3.4.2.1.1 states the control room area is only designed to $0.12 \mathrm{~g}$. Are these sections referring to the same control room?
The accident analysis performed for B Plant considers both a $0.12 \mathrm{~g}$ and $0.20 \mathrm{~g}$ seismic event. The WESF accident analysis cannot consider the effects of a $0.25 \mathrm{~g}$ event because B Plant did not do so. B Plant's response to a $0.25 \mathrm{~g}$ seismic event is unknown.

Designation of a "Hanford Site standard DBE" is not within the control of the WESF ISB preparers. Also, it is not clear that such a standard is desirable. For example, one would not want to build a PFP to the same seismic standards as office buildings. If the "margin" were increased for the new PFP-like building, then in essence, you have just created a more stringent design basis for the new PFP building la greater DBE).

The WESF DBE analysis in the ISB clearly demonstrates that the response of B Plant to a seismic event would not preclude operation of WESF even if protective equipment were required for workers. All structural interactions between WESF and $B$ Plant have been assessed and the B Plant endwall failure is considered. No other structural interactions would exist, even if B Plant were to completely collapse. The doses resulting from the $B$ Plant BDBE analysis are not anywhere near large enough to preclude operator entry into WESF.

Resolution accepted. However, I think the point was missed here to some degree, but that may be attributed to poor communication on the part of the reviewer. Note that in most cases, the seismic response capability of DOE facilities is typically based on postconstruction evaluation as opposed to design specification (i.e., the DBE designation is a bit of a misnomer). Regardless, the comment seems to indicate that WESF can be entered even under the conditions (i.e., structural damage and dose) associated with a BDBE and on that basis, the resolution is accepted. 


\begin{tabular}{|c|c|}
\hline 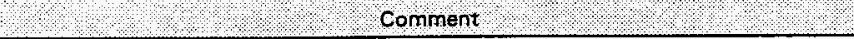 & 4.4 .44 .4 .4 .4 Response \\
\hline $\begin{array}{l}\text { Section } 3.4 .2 .2 .3 \text {, page } 3-88 \text {, does not accurately discuss the consequences of } \\
\text { aircraft impact, having excluded impacts to capsules and fuel fires. }\end{array}$ & $\begin{array}{l}\text { The aircraft crash evaluation points to the consequences of the BDBE } \\
\text { in addition to directly stating that the building structure may fail and } \\
\text { result in loss of all pool cell water. } \\
\text { Resolution accepted on the basis that the aircraft accident is in all } \\
\text { likelihood incredible, and that the consequences are probably bounded } \\
\text { by, or at least comparable to, the BDBE. Based on the discussion in } \\
\text { this section, I think the ISB would be better if it further justified the } \\
\text { accident as incredible (which it probably is) considering the no-flight } \\
\text { designation for the area. As written, the accident is neither } \\
\text { completely excluded on the basis of frequency, nor completely } \\
\text { included through fully developed scenario and consequence analysis. } \\
\text { The current reference to the BDBE is not appropriate since the } \\
\text { relationship between aircraft damage and BDBE damage is not } \\
\text { restablished. }\end{array}$ \\
\hline $\begin{array}{l}\text { Section } 3.4 .2 .3 .1 .1 \text {, page } 90 \text {, the fire-in-a-drum scenario is a bit of a stretch } \\
\text { particularly in assuming propagation to other drums. Under the assumption that } \\
\text { the lids are in-place and the drums are thus sealed, there would be little } \\
\text { available oxygen to support significant combustion internal to the drum and no } \\
\text { opportunity for propagating to the other drums. If, however, the drums are } \\
\text { open there is more validity to the scenario. Clearly state the assumed } \\
\text { configuration of the drums. If they are sealed, the scenario is not significant } \\
\text { and the controls specified at the end may not be needed. }\end{array}$ & $\begin{array}{l}\text { Accepted. Text added: "This assumption also encompasses possible } \\
\text { operating conditions in which the drums are not sealed or have their } \\
\text { lids entirely removed." } \\
\text { Resolution accepted. }\end{array}$ \\
\hline
\end{tabular}

configuration of the drums. If they are sealed, the scenario is not significant controls specified at the end may not be needed. 

combustible gases. This appears to be a overly simplistic and potentially flawed approach to evaluating the complex venting of combustion products.

Section 3.4.2.3.1.2, page $3-98$, states that hot cell temperatures reach $400^{\circ} \mathrm{C}$. What impact does this temperature, and the postulated fires in general, have on the oil filled windows? Discuss.
As the temperature increases and the pressure is held constant, a gas will tend to exhibit increasingly ideal behavior. This is because temperature is direct/y proportional to volume; an increase in temperature results in an increase in volume (constant P) and subsequent increase in the average distance between molecules which in turn reduces intermolecular interactions (an ideal gas has no molecular interactions). Generally, the concern over deviation from ideal behavior involves high pressures because an increase in pressure (constant $T$ ) results in a smaller volume (inverse/y proportional) and greater intermolecular interactions. So in the case of the hot cell fire, the pressure would be expected to remain approximately constant (perhaps a slight increase) while the temperature of the gases would increase resulting in a more ideal behavior of the gases.

,Resolution accepted. The point of my comment was not to request a discussion on the theory of the ideal gas law. My point was the applicability of the law to the postulated conditions. Fire results in smoke which is a combination of combustion gases and particulate matter released from the burning material. It is this mixture of particulate and gases that enters the canyon and not merely the gases. Regardless, the analysis appears to be conservative and the resolution is accepted on this basis.

Accepted. High temperature effects on the oil-filled glass windows has been evaluated. However, it is noted that the evaluation, and other impacts to hot cell SSCs, were not adequately incorporated into the analysis. A paragraph in the scenario development (Section 3.4.2.3.1.1) addresses potential impacts to facility SSCs. The following statements have been added to that discussion: "The elevated temperatures associated with the fire would cause a volume expansion of the oil layers in the hot cell windows. The heated oil would expand into reservoirs and would spill into the operating gallery if the reservoirs were overfilled. The oil is also non-flammable and the windows would not be otherwise impacted by the fire."

Resolution accepted. 
Section 3.4.2.3.1.3, page 3-101, Table 3.4.2.3-3. The onsite dose is calculated as 380 rem and the limiting offsite consequence is 0.68 , both of which exceed guidelines. While the offsite dose is easily mitigated by existing barriers, the onsite dose requires new and additional controls to be developed (see

3.4.2.3.1.4, page 3-103). This result is driven by what appears to this reviewer refining the analysis before instituting additional controls upon the facility. I do agree with the recommendation in 3.4.2.3.1.4 that combustible removal and control is appropriate. This is simply good practice and should not be driven by

Section 3.4.2.3.2.2, pages 109 and 110 , although difficult to believe, I will go along with the assumption that the suppression system does not extinguish the burning waste since the water would only act to float the burning fuel and the waste could be contained within the pool fire. However, the sprinklers would act to knock-down the release of radioactive material, thereby reducing the consequences. Again this is an example of conservative analysis that leads to potentially unnecessary controls. as an extremely conservative analysis and consideration should be given to the conclusions of an accident analysis.

Accepted. The simplistic and conservative nature of the analysis is recognized. More advanced modeling could be performed using fire compartment and aerosol transport codes. Given the purpose of the document to provide an interim safety basis for WESF, specifying the fire detection/suppression system as an interim control is simpler, more cost effective, and easily implementable by the facility. Based on this comment, however, the commitment to place a control on the combustibles has been made more general to include possible refinement in the fire model.

Resolution accepted.

In the unmitigated case, the fire suppression system is assumed to fail leading to unacceptable dose consequences. In this case, the fire suppression system could not possibly "knock down" any airborne contamination because it fails to function.

In the mitigated case, the fire suppression is shown to be able to completely preclude a release from the waste cask. In the absence of this release, the release from the solid waste alone is insignificant and whether or not any airborne contamination is removed by the fire suppression system is irrelevant. Therefore, based on the graded approach, more sophisticated modeling is not performed.

Resolution accepted.

Section 3.4.2.4.3.1, pages 123-131. The flooding scenario development discussion should be reduced to a more concise description of the event propagation. Based on the time period ( $z 10$ days) to generate the minimum explosive concentration of hydrogen necessary to make this a meaningful event, its legitimacy as an accident of concern is questionable.

Section 3.4.2.6.2.1, page 3-169, the frequency discussion is based on human errors necessary to cause an object to drop onto the capsules. This discussion appears to ignore the hydrogen explosion scenario in 3.4.3.5 that results in the ceiling and walls falling on the capsules. Revise accordingly.
Agreed. However, the scenario development is used not only to show the propagation of the event but to place the event sequence(s) into perspective with plant operations. In addition, DOE personnel have specifically requested that we address hydrogen generation and accumulation concerns throughout the facility.

Resolution accepted.

The statement on the basis of the qualitative frequency assignment was not based on the hazards evaluation effort and has been removed.

Resolution accepted. The acceptance of this resolution is based on the discussion above, which states that the frequency includes hydrogen explosion considerations. However, this does not change the fact that the text of the ISB states that this frequency term is based on human failures, indicating that this is the only source of capsule impact (i.e., there is no mention of the hydrogen explosion affects). 
Section 3.4.2.6.2.1, page 3-170, last para., states impacts on the capsules from hydrogen explosions are addressed in 3.4.2.5. But Section 3.4 .2 .5 references 3.4.2.6. This is one of many infinite loops created by cross-referencing in this accident analysis chapter.
Section 3.4.2.6.2 indicates that one of the potential initiators to a drop/impact event is a hydrogen explosion in the pool cell area, and references 3.4.2.5 for more details on that particular event sequence. Section 3.4.2.5 indicates that one of the possible consequences of a hydrogen explosion in the pool cell area is a drop/impact on the capsules, and references 3.4.2.6.2 for more details on the consequences. These are separate cross-references and not part of a "loop". Such cross-referencing is done to minimize repetition so that if information, models, etc. are modified then the change has a minimum impact.

Resolution accepted on the basis of the responses to similar reviewer comments earlier in this document. This is more of a format and content issue than a technical consideration. 

here to emphasize the point that the scenarios are not clearly established, no has the limiting scenario necessarily been addressed.

The limiting scenarios must be clearly established in the accident analysis. Those events such as hydrogen explosions that are merely initiators for other events should be characterized as such and should not be included in the detailed accident analysis section. If one follows the cross-referencing through the document, the following is the limiting scenario:

A $0.25 \mathrm{~g}$ earthquake resuits in a loss of electrical power. The loss of ventilation associated with the loss of power results in hydrogen accumulation in the pool cell area which is subsequently ignited. The damage from the deflagration results in multiple capsule impacts and damage to multiple pool cells resulting in loss of cooling water through leakage and evaporation. The current analysis does not appear to adequately assess the source term, consequences and necessary controls for this event.

The bottom line is that the accident analysis establishes that hydrogen explosions, loss of electrical power and other events can lead to a loss of cooling water. Therefore, the loss of cooling water scenario must ciearly establish the limiting conditions (e.g., power available or not available; capsule damage; facility structural integrity; etc.) that create the worst case credible accident.

It is recognized that the controls credited for preventing or mitigating consequences postulated in the accident analysis must address all of the identified sequences. Although some sequences have been developed in sections other than where the consequence analysis is presented, no case could be found where the indicated controls did not address all of the identified accident sequences.

Disagree. This reviewer cannot find where the source term and consequences have been developed for a combined failure of building confinement (hydrogen explosion scenario 3.4.2.5), capsule impacts (hydrogen explosion results in failure of wall and ceiling in pool cell area, 3.4.2.5.1) and loss of pool cell water (structural damage to cells from falling debris combined with evaporative losses caused by lack of makeup capability thydrogen build-up was caused by loss of ventilation, which could be attributed to the loss of electric power or earthquake events that would also fail makeup)). Although highly unlikely, this appears to be a legitimate scenario based on the analysis, but the source term for a combined capsule damage and loss of cooling water event with no confinement does not appear to be developed.

Recommendation. The scenario is extremely unikely and it is clear from the accident analysis that the source terms associated with loss of cooling water alone are unacceptable and analysis of the above scenario would arrive at the same conclusions. The combination of accident assumptions, and specified controls for hydrogen generation and loss of cooling water, further limit the possibility of this accident occurring. Therefore, for the purposes of the ISB, the accident analysis is acceptable for establishing facility safety parameters. However, the scenario development issue should be revisited during SAR development to ensure that all postulated combinations of credible event sequences and system failures have been adequately considered.

Based on the above recommendation, this resolution is accepted. 


\begin{tabular}{|c|c|}
\hline Comment & Response \\
\hline $\begin{array}{l}\text { Closing Comment: } \\
\text { Because of the excessive conservatism contained within the ISB accident } \\
\text { analysis, it is likely that the consequences of any realistically conceivable } \\
\text { accidents at WESF have been bounded. However, this conservatism can } \\
\text { potentially lead to unnecessary, and costly, facility and administrative controls. } \\
\text { In addition, the document, in its current condition, is totally inadequate as a } \\
\text { device for risk/safety communication and management, particularly with regard } \\
\text { to performance of USODs. } \\
\text { The WESF is a virtually static storage facility consisting of contaminated, but } \\
\text { generally unused hot cells and a storage pool that requires monitoring and } \\
\text { periodic cooling water makeup. The accident analysis for such a facility, does } \\
\text { not need to be so complex and cumbersome. }\end{array}$ & $\begin{array}{l}\text { It is recognized that the analysis is conservative and appears to be } \\
\text { complex. This conservatism, however, is driven by two } \\
\text { considerations: the lack of knowledge concerning key parameters in } \\
\text { the analysis, and the simplicity of the facility and operations. A } \\
\text { simple facility generally leads to very little room to deviate from } \\
\text { Handbook release fractions, advanced modeling, etc. which might } \\
\text { show less conservative results. The analysis itself is relatively simple, } \\
\text { release fractions times source term and that sort of thing. The } \\
\text { apparent complexity arises from the on-going review comments to } \\
\text { continually show (in increasing detail) that the analysis considered } \\
\text { everything and that there are no holes (everything is documented, } \\
\text { supported, referenced, etc.). } \\
\text { In regards to the document not providing an adequate means of } \\
\text { communicating and managing risk/safety (especially for USaDs), the } \\
\text { exact opposite is true. The controls identified for the safe operation } \\
\text { of the facility are spelled out explicitly and each control has a } \\
\text { thoroughly documented basis all the way back to the hazards } \\
\text { evaluation. The accident selection and analysis processes have been } \\
\text { documented and show that every deviation which has been identified } \\
\text { is accounted for in the accidents land defense-in-depth, worker } \\
\text { safety, environmental protection), and subsequently in the controls. } \\
\text { In the early stages of writing, careful consideration had been given to } \\
\text { the performance of UsQs against the analysis, and facility personnel } \\
\text { (both engineers who perform the Usos and management) have } \\
\text { agreed that the document will be excellent for resolving Usos. } \\
\text { Resolution accepted. } \\
\text { However, I disagree with the opening comment that suggests } \\
\text { simplicity drives conservatism. Conservatism is much more important } \\
\text { in complex systems where there is extreme difficulty in evaluating all } \\
\text { possible combinations of failures and interactions. You are correct in } \\
\text { identifying that the acceptability of this document ultimately lies with } \\
\text { the WESF engineering, operations and management personnel that } \\
\text { must use it. }\end{array}$ \\
\hline
\end{tabular}



$-$

\section{Document Number(s)/Title(s) \\ WESF ISB Accident Analysis} Review

17. Comment Submittal Approval:

Organization Manager (Optional)

\section{Program/Project/} Building Number

,
8. Organization/Group

PNNL
9. Location/Phone

$372-4239$
Phil Daling
10. Agreement with indicared comment disposition(s)
11. CLOSED

$9 / 17 / 96$

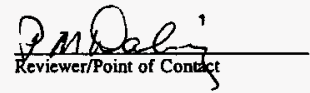

\begin{tabular}{|c|c|c|}
\hline Conment & Hold-point & 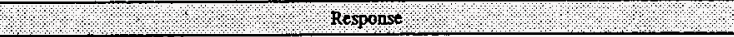 \\
\hline Section 3.4.2.1.2.1, 9th paragraph. What about the pumps? & & Accepted. Potential failure of the recirculation pumps is added to the discussion. \\
\hline $\begin{array}{l}\text { Section 3.4.2.1.2.1, 12th paragraph. Address the potential for a cover block to fall onto a } \\
\text { capsule in the pool or structural debris falling onto a capsule in a process cell. }\end{array}$ & & $\begin{array}{l}\text { Since the pool cell bridge crane (carrying a load) and pool cell structure are designed for } \\
\text { DBE loads, their failure and potential drop of a cover block into a pool cell are covered in } \\
\text { the Section 3.4.3, BDBE. Likewise, because the hot cell structure is designed to survive } \\
\text { the DBE, the failure of the hot cell structure and subsequent potential impacts to capsules is } \\
\text { addressed in Section 3.4.3. } \\
\text { Evaluation: Could not find discussion in Section } 3.4 .3 \\
\text { Follow up: Discussion focated and accepted. }\end{array}$ \\
\hline $\begin{array}{l}\text { Section } 3.4 .2 .1 .2 .2 \text {, 2nd paragraph. Address material held up in the K-1 ventilation } \\
\text { system, or is it clean. }\end{array}$ & & $\begin{array}{l}\text { The K-1 system is clean. } \\
\text { Evaluation: response accepted. }\end{array}$ \\
\hline $\begin{array}{l}\text { Section } 3.4 .2 .1 .2 .2,4 \text { th paragraph, last sentence. This looks like you doubled the above } \\
\text { estimates. Clarify. }\end{array}$ & & $\begin{array}{l}\text { The inventories were summed for the hot cells. No doubling was performed. } \\
\text { Evaluation: response accepted. }\end{array}$ \\
\hline $\begin{array}{l}\text { Section 3.4.2.2.1.1, 3rd paragraph, last sentence. "Automatic Switches" does this include } \\
\text { the breakers and buswork. }\end{array}$ & - & $\begin{array}{l}\text { "Switches" includes any component of the automatic system designed to initiate and activate } \\
\text { the backup diesel generator. } \\
\text { Evaluation: This response needs to be added to the text } \\
\text { Follow up: added. }\end{array}$ \\
\hline $\begin{array}{l}\text { Section 3.4.2.2.3. 7th paragraph. Might also point out that the accident frequency } \\
\text { associated with damaging a vital piece of equipment is even lower due to, e.g., crash } \\
\text { barriers around outdoor equipment, structural integrity of the building, etc. }\end{array}$ & & $\begin{array}{l}\text { Accepted. Statement added: "This value is conservative for application to hazards and } \\
\text { safety analyses because many vehicle accidents may occur above the property damage } \\
\text { threshold, which do not result in impacts to vital facility SSCs. } \\
\text { Evaluation: Could not find discussion in Section } \\
\text { Follow up: discussion located and accepted. }\end{array}$ \\
\hline $\begin{array}{l}\text { Section 3.4.2.3.1.1, 12th paragraph, } 2 \text { nd sentence. Explain why the steam jet would have } \\
\text { little effect. Change "activare" to "active" in the last sentence. }\end{array}$ & & $\begin{array}{l}\text { Sentence has been deleted. Word changed. } \\
\text { Evaluation: Could not locate text revisions } \\
\text { Follow up: revisions located and accepted. }\end{array}$ \\
\hline
\end{tabular}


WHC-SD-WM-DRR-058 Rev, 0

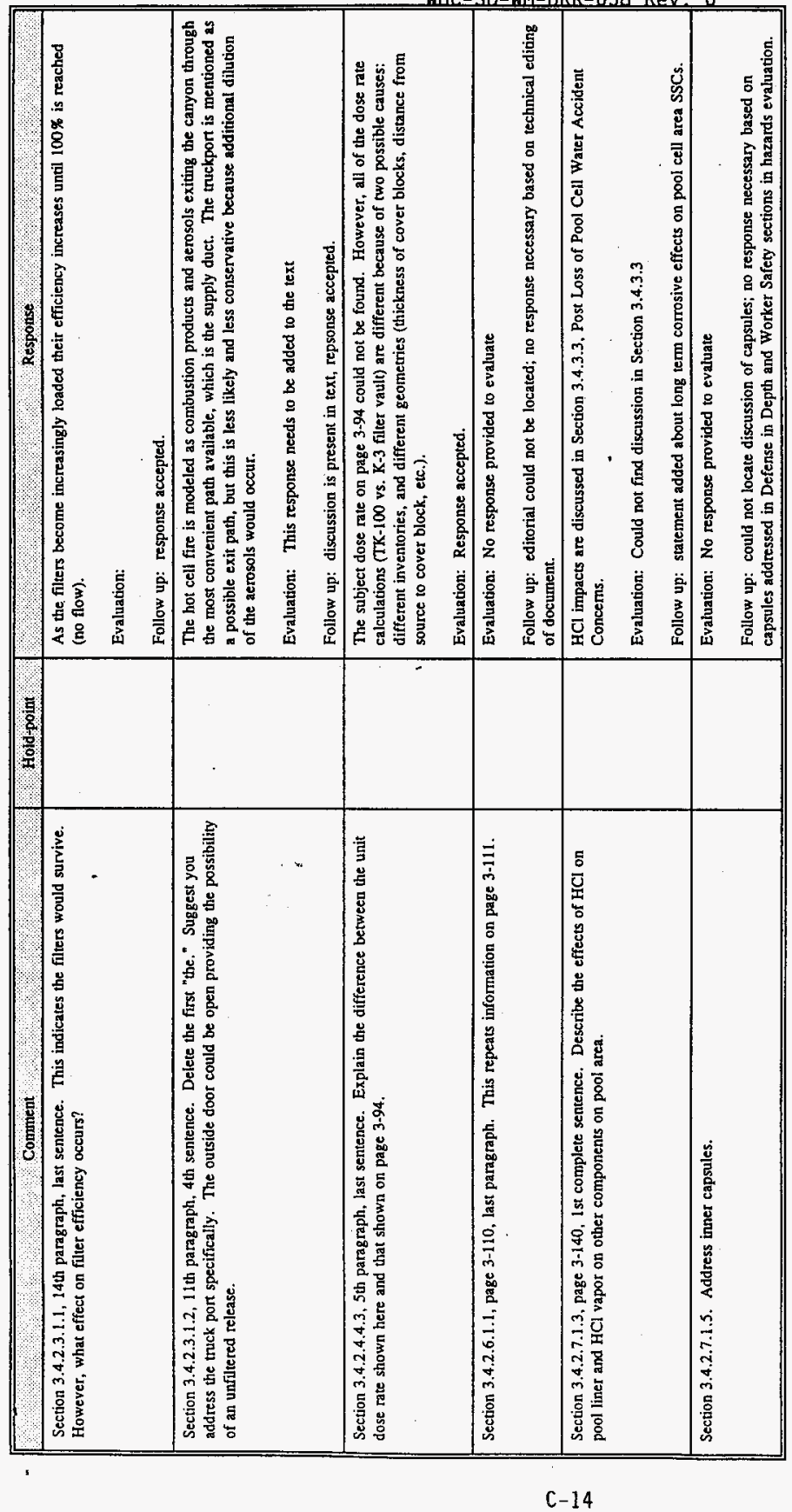


5. Document Number(s)/Title(s)

WHC-SD-WM-ISB-009 REV 0/Chapter 3.0 Only

17. Comment Submittal Approval:

Organization Manager (Optionail
6. Program/Project/ Building Number

ED6324
7. Reviewer

Raymond HV Gallucci
8. Organization/Group

$\mathrm{PN}^{2} \mathrm{~L} /$ D9T14
9. Location/Phone

EESB-2235/3724284
10. Agreement with indicated comment disposition(s)

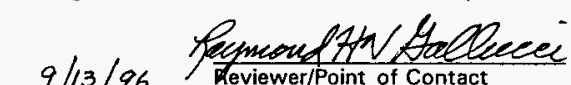
11. CLOSED

\begin{tabular}{|c|c|c|}
\hline Conment & Hotd-point & (2) Response \\
\hline $\begin{array}{l}\text { GENERAL: A technical editor will be needed to correct frequent misuse of Affect and Effect } \\
\text { throughout chapter, as well as singulor vs. plural subject-predicate disagreements. }\end{array}$ & & $\begin{array}{l}\text { Accepted. A thorough tech editing is in-process. } \\
\text { Evaluation: Accepted }\end{array}$ \\
\hline $\begin{array}{l}\text { 53.1, p. 3-2. Table } 3.1-1 \text { appears without introduction or discussion. Also, a footnote on the } \\
\text { Severity, Frequency, Risk Rank cotumn is needed to direct the reader to the appropriate place } \\
\text { where the terms S3, F2, R3, etc., are defined. }\end{array}$ & & $\begin{array}{l}\text { Aecepted. An introductory paragraph has been added as well as a footnote to the eppropriate } \\
\text { definitions. } \\
\text { Evaluation: Accepted }\end{array}$ \\
\hline 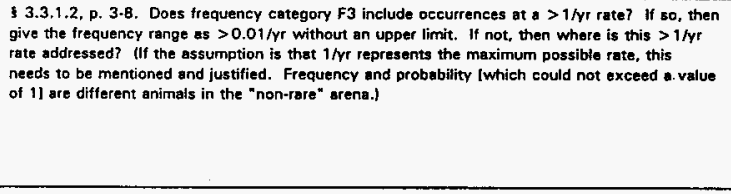 & (3) $e_{R G}$ & 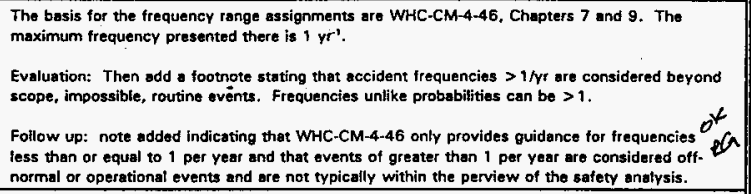 \\
\hline 3 3.3.2.1, Table 3.3.2.1-1, p. 3-12. No electrical energy hazard sources? & & $\begin{array}{l}\text { The hazards identificetion toble is designed to identify hazardous matorials and energies not } \\
\text { normally accepted by the public or industry. No extraorfinary electrical hazards were identified } \\
\text { at WESF. } \\
\text { Evaluation: Accepted }\end{array}$ \\
\hline 3.3.2.1, p. 3-13. Grammar: Add verb to "However, many ... unusual occurrences." & & $\begin{array}{l}\text { Sentence reads: "However, many operational events and off-normal occurrences (described in } \\
\text { anecdotal fashion, tectnical reports, and ocecurrence reportsl can be summarized in the following } \\
\text { categories; capsule upsets, tecility nestr-eceldent events, and unusual oceurrencess." }\end{array}$ \\
\hline $\begin{array}{l}\text { 15 3.3.2.2, p. 3-17. The first equation contains the term } 22 / 0 \text { in the denominator, an infinite } \\
\text { value. It might appear better if this equation was rewriten as }(3 / 89)^{\prime} 52000+(0 / 22)^{*} 23,000 \\
=1750 \text {. }\end{array}$ & & $\begin{array}{l}\text { Evaluation: No response provided to evaluate } \\
\text { Follow up: equations have been simplified to exclude the divide by zero term. ok en }\end{array}$ \\
\hline 3.3.2.3, p. 3-19. Table 3.3.2-6 should be Table 3.3.2-5. & & $\begin{array}{l}\text { Tebles have been renumbered and the correct cell-ours spplied. } \\
\text { Evaluation: Accepted }\end{array}$ \\
\hline
\end{tabular}




\begin{tabular}{|c|c|c|}
\hline . & Hold-point: & Response \\
\hline 5 3.3.2.3.1, p. 3.25. Acronym CLCS needs to be defined. & & $\begin{array}{l}\text { Accepted. CLCS is Closed Loop Cooling System, and is spefled out at the first occurrence. } \\
\text { Evaluation: Accepted }\end{array}$ \\
\hline 3 3.3.2.3.2, p. 3-33. Typo: associate $\rightarrow$ associated. & & $\begin{array}{l}\text { Corrected. } \\
\text { Evaluation: Accepted }\end{array}$ \\
\hline 9.3.2.3.2, p. 3-33. Typo: "Timely transfer ... also act to prevent the ... the tank." & & $\begin{array}{l}\text { Corrected. } \\
\text { Evaluation: Accepted }\end{array}$ \\
\hline $\begin{array}{l}\text { 5 3.3.2.3.2, p. 3.37. While the WESF waste and BUSS casks may pose a similar magnitude } \\
\text { kinetic energy hazard as the coverblocks, does their smaller size make a drop more likely to } \\
\text { impact within a pool cell than that of \& coverblock, which requires an edge-on orientation?. }\end{array}$ & & $\begin{array}{l}\text { The WESF waste and BUSS casks are not moved into the pool cell ares. } \\
\text { Evaluation: Accepted }\end{array}$ \\
\hline 3.3.2.3.2, Table 3.3.2.3-5, p. 3-38. Typo: bollarts $\rightarrow$ bollards. & & $\begin{array}{l}\text { Changed to "traffic barriers". } \\
\text { Evaluation: Accepted }\end{array}$ \\
\hline $\begin{array}{l}\text { 3. 3.3.2.3.2, Table 3.3.2.3-5, p. 3-38. Typo: Acronym mismatch between IOSR and TSR in } \\
\text { tootnote } 8 \text { ? }\end{array}$ & & $\begin{array}{l}\text { Currently in the process of removing all references to TSRs and replacing with 1OSRs. Chango } \\
\text { made to IOSR in footnote. } \\
\text { Evaluation: Accepted }\end{array}$ \\
\hline 3 3.3.2.3.2, Table 3.3.2.3-5, p. 3-40. Typo: Remove "Y" after SS? & & $\begin{array}{l}\text { 7" deleted. } \\
\text { Evaluation: Accepted }\end{array}$ \\
\hline 3.3.2.3.3, p. 3-42. TYpo: filer $\rightarrow$ filter. & & $\begin{array}{l}\text { Change made. } \\
\text { Evaluation: Accepted }\end{array}$ \\
\hline $\begin{array}{l}\text { \{ 3.3.2.3.3, p. 3-42. Typo: "An administrative ... the number OF bags and ... radiation } \\
\text { exposure." }\end{array}$ & & $\begin{array}{l}\text { Change made. } \\
\text { Evaluation: Accepred }\end{array}$ \\
\hline 3 3.3.2.3.3. p. 3-43. Typo: "To enable ... controls cool the wator CAPSULES." & & Change made. \\
\hline $\begin{array}{l}\text { 3.3.2.3.3, p. 3-44. Typo: "A hydrogen ... the energy OF the explosion ... radioactive } \\
\text { particles." }\end{array}$ & & $\begin{array}{l}\text { Change made. } \\
\text { Evaluation: Accepted }\end{array}$ \\
\hline 3.3.2.3.5.2, Figure 3.3.2.3-1. p. 3-48. Acronyms LOEP and LOWA should be defined here. & & $\begin{array}{l}\text { Evaluation: No response provided to evaluate } \\
\text { Follow up: all abbreviations and acronyms will be spelled out in the figure for ease of reading. }\end{array}$ \\
\hline 1 3.3.2.3.5.2, p. 3.52. Typo: sever $\rightarrow$ severe. & . & $\begin{array}{l}\text { Change made. } \\
\text { Eveluation: Accepted }\end{array}$ \\
\hline $\begin{array}{l}\text { I 3.4.1.4. Table 3.4.1-6, p. 3-60. See previous comment from \$ 3.3.1.2, p. 3.8, regarding } \\
\text { frequencies }>1 / \mathrm{yr} \text {. }\end{array}$ & Qte & $\begin{array}{l}\text { See previous response. } \\
\text { Evaluation: See previous comment to response. }\end{array}$ \\
\hline $\begin{array}{l}\text { 5 3.4.2.1.1, p. 3-65. Since the SSC equipment in Areat } 1 \text { is tater assumed to fail during a DBE } \\
\text { (p. 3-67), the following clarification is suggested: "It is ... not confirmed OR CREDTTED DURING } \\
\text { DBE ANALYSIS, that Area 1 ... Wagenblast 1996)." }\end{array}$ & & $\begin{array}{l}\text { Change made. } \\
\text { Evaluation: Accepted }\end{array}$ \\
\hline 3.4.2.1.2.1, p. 3-69. Typo: "Since the ... a subsequent FalluRE[?] of the ... outlet ducting." & & $\begin{array}{l}\text { Sentence has been fixed. } \\
\text { Evaluation: Accepted }\end{array}$ \\
\hline
\end{tabular}




\begin{tabular}{|c|c|c|}
\hline Coment 184 & Hold-point & Response \\
\hline 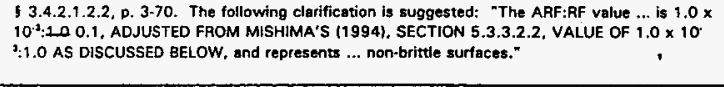 & & $\begin{array}{l}\text { This adjustment has been removed based on other review comments. The Handbook release } \\
\text { fraction is now used unaltered. The text has been changed appropriately. } \\
\text { Evaluation: Accepted }\end{array}$ \\
\hline 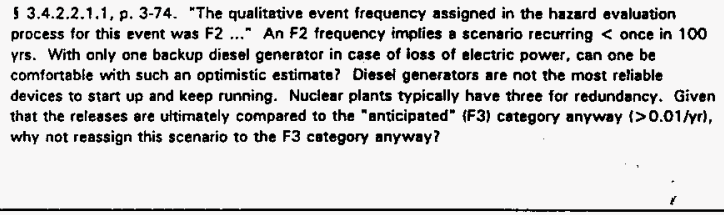 & & $\begin{array}{l}\text { The frequency assignments were made during the hazards evaluation as the tesm consensus on } \\
\text { the likelthood of the event. The assignments were then used as part of the accident selection } \\
\text { process. These assignments were not revisited based on the results of the accident analysis, } \\
\text { but simply used as o starting point from which the accident analysis is performed. This aiso } \\
\text { preserves the integrity of the hazards evaluation process by not allowing individual analysts to } \\
\text { alter the evaluation results. In addition, the frequency assignments do not play a role in the } \\
\text { accident analysis fi.e., sll could be F3 and it wouldn't alter the conclusions) and littie could be } \\
\text { gained by re-evaluating all the frequency (and consequence) assignments. } \\
\text { Evaluation: Accepted }\end{array}$ \\
\hline $\begin{array}{l}\text { 3.4.2.2.1.1, 0. 3-75. Type: "Accident progressions ... for loss Of cooling and ... Section } \\
\text { 3.4.2.7." }\end{array}$ & & $\begin{array}{l}\text { Change made. } \\
\text { Evaluation: Accepted }\end{array}$ \\
\hline 1 3.4.2.3.1.1, 0. 3.82: Typo: activate $\rightarrow$ activated. & & $\begin{array}{l}\text { Change made. } \\
\text { Evaluation: Accepted }\end{array}$ \\
\hline $\begin{array}{l}\text { 3.4.2.3.1.2, p. 3-85: Equation at top of page } 3-86 \text { belongs after "Solving the ... values } \\
\text { yields:" on p. 3-85. }\end{array}$ & & $\begin{array}{l}\text { The text is before the equation. Sometimes WP } 5.1 \text { equations mess up page layouts. Since the } \\
\text { chapter is continuing to undergo change, these corrections will be made in the final tech editing. } \\
\text { Evaluation: Accepted }\end{array}$ \\
\hline 3 3.4.2.3.1.2, p. 3-86. Grammar: Add verb to "Also, since ... cellulosic combustibles." & & $\begin{array}{l}\text { Change made. } \\
\text { Evaluation: Accepted }\end{array}$ \\
\hline $\begin{array}{l}\text { 3.4.2.3.2.1, p. 3.95. Typo: "It is postulated ... one of four THAEE possible operating ... door } \\
\text { open." }\end{array}$ & & $\begin{array}{l}\text { There are four posstble conditions; the fourth was inadvertently deleted. It has been added } \\
\text { again and is "rollup doox closed and cover block in-place." } \\
\text { Evaluation: Accepted }\end{array}$ \\
\hline $\begin{array}{l}\text { 3.4.2.3.2.1, p. 3-95. "Although the cover-block and roll-up door are not allowed to open } \\
\text { simultaneously becouse of operational impacts to the K-3 ventilation system ..." Specify } \\
\text { whether this "disallowance" is physicelly impossible or merely procedurally prohibited. }\end{array}$ & . & $\begin{array}{l}\text { Text added: "... loperational restriction onlyl ..." } \\
\text { Evaluation: Accepted }\end{array}$ \\
\hline 1 3.4.2.3.2.1, p. 3-96. Typo: be come $\rightarrow$ become. & & $\begin{array}{l}\text { Change made. } \\
\text { Evaluation: Accepted }\end{array}$ \\
\hline 3.4.2.4.2.5, p. 3-109. Typo; Footnote 17 requires numbering. & $\cdot$ & $\begin{array}{l}\text { Change made. } \\
\text { Evaiuation: Accepted }\end{array}$ \\
\hline $\begin{array}{l}\text { 3.4.2.4.3.1, p. 3-116. Typo: "For the mitigated ... mixture of hydrogenl,] oxygen end air cen } \\
\text { be generated." }\end{array}$ & & $\begin{array}{l}\text { Change made. } \\
\text { Evaluation: Accepted }\end{array}$ \\
\hline
\end{tabular}




\begin{tabular}{|c|c|c|}
\hline 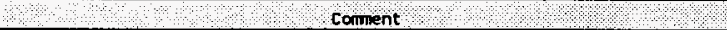 & Hotd-point: & 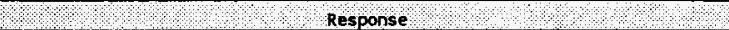 \\
\hline 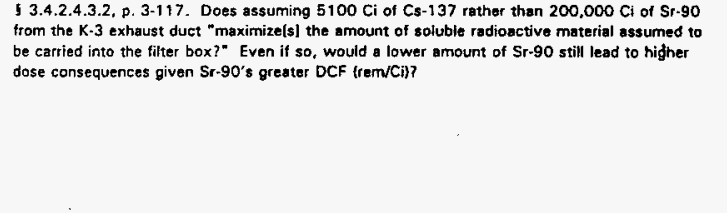 & $x$ & 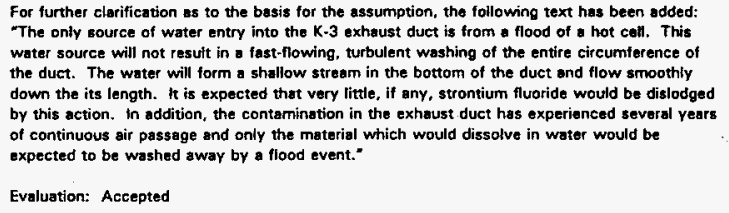 \\
\hline $\begin{array}{l}\text { 53.4.2.4.3.2, p. 3.117. The equations for } \mathrm{E} / \mathrm{CS}, \mathrm{H} 2 \mathrm{O} \text { and } \mathrm{E} / \mathrm{Ba}, \mathrm{H} 2 \mathrm{O} \text { on p. 3.118 need to be } \\
\text { moved to p. 3.117. }\end{array}$ & & $\begin{array}{l}\text { See previous comment pertaining to equations. } \\
\text { Evaluation: Accepted }\end{array}$ \\
\hline \$ 3.4.2.4.3.3, p. 3-122. TYpo: "... scenarios since s conditions necessary ..." & & $\begin{array}{l}\text { Change made. } \\
\text { Evaluation: Accepted }\end{array}$ \\
\hline 3.4.2.4.4.2, p. 3-126. The equation for time on p. $3-127$ needs to be moved to p. $3-126$. & & $\begin{array}{l}\text { See previous comment pertaining to equations. } \\
\text { Evaluation: Accepted }\end{array}$ \\
\hline $\begin{array}{l}\text { 3 3.4.2.4.4.2, p. 3-128. Typo: "the BB-137 daughter product is accounted for IN the dose } \\
\text { calculations)." }\end{array}$ & & $\begin{array}{l}\text { Change made. } \\
\text { Evaluation: Accepted }\end{array}$ \\
\hline $\begin{array}{l}\text { 3.4.2.4.5.1, p. 3.131. The equation for Cs-137/8B-1137m energy rate contriburion on p. } 3 \text { - } \\
132 \text { needs to be moved to p. } 3-131 \text {. }\end{array}$ & & $\begin{array}{l}\text { See previous comment pernaining to equations. } \\
\text { Evaluation: Accepted }\end{array}$ \\
\hline 3 3.4.2.4.5.1, p. 3.134. Typo: "G Cell ... in the bues BUSS cask and transfer setivities." & & $\begin{array}{l}\text { Change made. } \\
\text { Evaluation: Accepted }\end{array}$ \\
\hline 3 3.4.2.5.2, p. 3-139. Typo: resotration $\rightarrow$ restoration. & & $\begin{array}{l}\text { Change made. } \\
\text { Evaluation: Accepted }\end{array}$ \\
\hline 3 3.4.2.5.3, p. 3.140. Typo: resotration $\rightarrow$ restoration. & & $\begin{array}{l}\text { Chsnge made. } \\
\text { Evaluation: Accepted }\end{array}$ \\
\hline 1 3.4.2.5.5, p. 3-140. Typo: "The risk is easily mitigated by the control[S] credited below." & & $\begin{array}{l}\text { Change made. } \\
\text { Evaluation: Accepted }\end{array}$ \\
\hline 5 3.4.2.6.1.1, p. 3-143. Typo: Footnotes 18 and 19 require numbering. & & $\begin{array}{l}\text { Change made. } \\
\text { Evaluation: Accepted }\end{array}$ \\
\hline $\begin{array}{l}\text { 5 3.4.2.6.1.1. p. 3-143. Figure 3.4.2.6-1 needs to have right axis labeled as well as curve with } \\
\text { open squares. }\end{array}$ & & $\begin{array}{l}\text { Evaluation: No response provided to evaluate } \\
\text { Follow up: the sxis will be labeled as appropriate and the curve will be titled. oK RG }\end{array}$ \\
\hline 5 3.4.2.6.2.3, p. 3-154. In equation for time, what is the term $1.13 \mathrm{E}-2 \mathrm{~s} / \mathrm{m} 3$ ? & & $\begin{array}{l}\text { This is the } X / q \text { value. Text has been added to fully define and reference all of the values used in } \\
\text { the equation. } \\
\text { Evaluation: Accepted }\end{array}$ \\
\hline
\end{tabular}

\section{A-6400-090.1 (03/92) WEFO11}




\begin{tabular}{|c|c|c|}
\hline comenent & Hotd point & Response: \\
\hline I 3.4.2.7.1.3, p. 3-165. Typo: Footnotes 20 and 21 require numbering. & & $\begin{array}{l}\text { Change made. } \\
\text { Evaluation: Accepted }\end{array}$ \\
\hline \& 3.4.2.7.2.1, p. 3-167. Typo: forth $\rightarrow$ fourth. & & $\begin{array}{l}\text { Change made. } \\
\text { Evaluation: Accepted }\end{array}$ \\
\hline $\begin{array}{l}\text { 3.4.2.7.2.1, p. } 3 \cdot 167 \text {. The fifth and sixth failure mechanisms from p. } 3-166 \text { are not discussed } \\
\text { specificatly, as are the first four. For completeness, they should at least be mentioned fond then } \\
\text { dismissed, if appropriate). }\end{array}$ & & $\begin{array}{l}\text { Accepted. Sentences added to describe these failure mechanisms in the same fashion as the } \\
\text { first } 4 \text {. } \\
\text { Evaluation: Accepted }\end{array}$ \\
\hline $\begin{array}{l}\text { 1 3.4.3.2.1, p. 3-176. Typo: "SDC-4.1 stipulates ... Ifrequency rank of E F2 in the hazards } \\
\text { evaluation)." }\end{array}$ & & $\begin{array}{l}\text { Change made. } \\
\text { Evaluation: Accepted }\end{array}$ \\
\hline $\begin{array}{l}\text { 5.4.3.2.1, p. 3-176. The } 0.25 \mathrm{~g} \text { earthquake, with its frequency of } 5 E-4 / \mathrm{Yr} \text {, falls into the } F 2 \\
\text { category (unlikelyl, not the } F 1 \text { category (extremely unlikely). yielding the more severe risk rank } \\
\text { of } \mathrm{A3} \text {, not } \mathrm{R} 2 \text {. Further, if a } 0.20 \mathrm{~g} \text { earthquake is assigned a } 1 E-4 / \mathrm{Vr} \text { frequency, shouldn't a } \\
\text { higher-g earthquake have a lower, not higher, frequency? There are diserepancies here that } \\
\text { must be resolved. }\end{array}$ & Ha & $\begin{array}{l}\text { Evatuation: No response provided to evaluate } \\
\text { Foliow up: the reference to the frequency of the } 0.20 \mathrm{~g} \text { event has been removed because it is } \\
\text { irrelevant to the WESF. The frequency for the } 0.25 \mathrm{~g} \text { from the Tallman reference is used and } \\
\text { falls into the } \mathrm{F} 2 \text { fange, resulting in a risk rank of } \mathrm{R3} \text {. The text has been updated accordingly. }\end{array}$ \\
\hline $\begin{array}{l}\text { 3.4.3.2.2. p. 3-178. Typo: "Although the pool cell water would BE lost immediately, ... } \\
\text { chloride released." }\end{array}$ & & $\begin{array}{l}\text { Change made. } \\
\text { Evaluation: Accepted }\end{array}$ \\
\hline 5 3.4.3.3, p. 3-180. Typo: "Rack average ... will not be high ENOUGH to ceuse failures." & & $\begin{array}{l}\text { Change made. } \\
\text { Evaluation: Accepted }\end{array}$ \\
\hline
\end{tabular}


5. Document Number(s)/Title(s)

Draft WESF ISB Accident Analysis Chapter 3

17. Comment Submittal Approval:

Organization Manager (Optional)

6. Program/Project/ Building Number WESF
7. Reviewe

Yosen Liu
8. Organization/Group

PNNL

10. Agreement with indicated comment disposition(s)

11. CLOSED

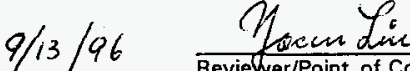
Reviewer/Point of Contact $\quad 9 / 13 / 96$ Date

In Table 3.3.2.3.-2, Summary of HAZOP S1 Deviations, the deviations are listed in three different categories, i.e., (1) Spread of Contamination; (2) Hazardous Material/fiedation Exposure; and (3) industrial Concerns. The distinction between (1) and (2) is not eleer. All items in category (1) ore repeated in category (2) on page T3-4. A more clear eategorization of the deviations seems desirable, probably based on the way the deviations were compiled such as using the accident types in Table 3-6, or based on their locations or operations. Further, the format of Tables 3-2, 3-3, and 3-4 should be consistent. (Resubmitted)

3. Pege T3-1 of Accident Anelysis and Page TB-2, Appendix B of HAZOP Evaluation and Accident Selection.

In Table 3.3.2.3.1, there are only 26 nodes while 27 nodes are listed in Table B-2. Also in Tabie

B.2. Node 23 appesers twice with different definitions on page TB-47 and TB-48. (Resubritted)

Hold-point

Major assumptions not summarized in either the unmitigated and mitigsted cas es, which are the only two cases presented in the snalysis, could not be found. The list of major assumptions is presented following the analysis to serve as a summary of the most significant assumptions associated with the analysis. The frequency and consequence rankings are ba sed on the hazards evaluation, not the results of the accident analysis.

Evaluation: Accepted

The HAZOP Summary S1 Deviations toble is not entirely repetitive from column 1 to column 2. For example, "Flood of Truckport", "K-1 Ventilation Failure/Upsets", and others from column 1 ere not repeated in column 2. The information in the HAZOP summary deviation tables is extracted directly from the HAZOP, with the $\$ 2$ and $\mathrm{S} 3$ deviations tables copied exactly. The length of the S1 deviations table, however, made it desirabie to atter the format slightly and in doing so the information was presented in an easier-ta-read fashion. Some limited rapetition between columns was the price for the altered format.

Evaluation: Accepted; however, it may be appropriate during the preparation of the FSAR, to reformat the Tables for clarity and consistency.

The node listings and related discrepancies are from the HAZOP which formed the basis of the hazards evaluation in Tables B-2 and B-3 (now called A-2 and A-3). It was dasired to alter the presentation of B-2 ss litve as possible so that reviewers would find almost identical tables in both the hazards eveluation and the HAZOP. Therefore, instead of renumbering nodes, an item number" was added for each deviation (this also drastically increased the usability of the tabte).

Evaluation: Accepted; however, it may be appropriate during the preparation of the FSAR, to reformat the Tables. 


\begin{tabular}{|c|c|c|}
\hline ४ & Hotopont & Response \\
\hline $\begin{array}{l}\text { 4. Genera! } \\
\text { The descriptions in Section 3.4.2. Design Basis Accidents, are very lengthy and affect the } \\
\text { reader's focus on accident scenario and consequence results. For example, on page 3-173, } \\
\text { Section } 3.4 .2 .7 .1 \text { Lots of Water from . Single Pool Cell, there are very detailed descriptions of } \\
\text { the pool liner and the pool cell drain lines. This type of information could be moved to the } \\
\text { corresponding locations in Chspter 2, Fucility Description. Only accident onalysis related } \\
\text { information needs to be included in Chapter } 3 \text {. }\end{array}$ & & 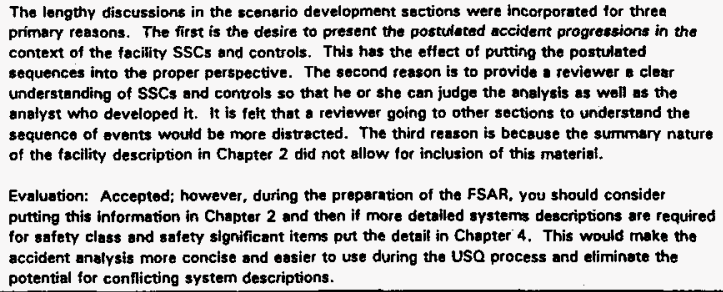 \\
\hline $\begin{array}{l}\text { 5. General } \\
\text { A significant number of accidents are interrelated, resulting in a great number of cross } \\
\text { references in Section } 3.4 \text {, Accident Anslysis. These cross references are difficult for the reader } \\
\text { to follow and ore confusing. It would be helptul if Figure } 3.3 .2 .3-1 \text { cousd be upgraded inot } \\
\text { tegible on page } 3-51 \text { ) and summary be added to illustrate the inter-relationships of the } \\
\text { accidents. }\end{array}$ & & $\begin{array}{l}\text { Accepted. The figure has been updated and a summary has been added. } \\
\text { Evaluation: Accepted; however during the prepartion of the FSAR the accident analyses would } \\
\text { be oasier to follow with less forward and back referencing. You should always toy to reference } \\
\text { back to completed analyses. If this is not possible it may be appropriate to reformat the } \\
\text { Chapter. }\end{array}$ \\
\hline $\begin{array}{l}\text { 7. Page } 3-60 \text {, Section } 3.4 .1 \text { Methodology, 2nd paregraph } \\
\text { "Safety Structures, Systems, and Components" should be "Safety Systems, Structures, and } \\
\text { Components." }\end{array}$ & & $\begin{array}{l}\text { Change made. } \\
\text { Evaluation: Accepted }\end{array}$ \\
\hline $\begin{array}{l}\text { 8. Page 3-85, 1st paregraph, } 2 \text { nd tine } \\
\text { "Section } 3.4 .2 .7 .1 " \text { should be }-3.4 .2 .5 .5 " \\
\text { 2nd paragraph, 2nd line } \\
\text { "Section } 3.4 .2 .7 .1 " \text { should be "Section } 3.4 .2 .7 .5 . " \\
\text { Please check gll other section numbers used in the cross reference. }\end{array}$ & & $\begin{array}{l}\text { Reference to Section 3.4.2.7.1 changed to 3.4.2.7 toss of pool cell woter). } \\
\text { Evaluation: Accepted }\end{array}$ \\
\hline $\begin{array}{l}\text { 9. Page 3-94, last paragraph. } 1 \text { st sentence } \\
\text { "The total quantity of ...." has a grammar probtem and is not understandable. }\end{array}$ & & $\begin{array}{l}\text { Sentence fixed. } \\
\text { Evaluation: Accepted }\end{array}$ \\
\hline $\begin{array}{l}\text { 10. Page 3-97, last paragraph, 2nd sentence } \\
\text { "The ratio .... of" is not completed. }\end{array}$ & & Sentence fixed. \\
\hline $\begin{array}{l}\text { 11. Page } 3 \cdot 98 \text {, bottom } \\
\text { The definition of } C_{p} \text { below the equation is not completed. }\end{array}$ & & $\begin{array}{l}\text { Definition corrected. } \\
\text { Evaluation: Accepted }\end{array}$ \\
\hline $\begin{array}{l}\text { 12. Page } 3-120 \\
\text { Section titlo } 3.4 .2 .4 .2 .1 \text { Scenario Development is missing. }\end{array}$ & - & $\begin{array}{l}\text { The format and content of the accident analysis in general is not followed for the loss of K-3 } \\
\text { ventilation flow. Because of the limited nature of the consequences, this event is not quantified } \\
\text { and so the presentation was shortened appropriately. } \\
\text { Evaluation: Add the section and follow with a discussion why the accident scenario was not } \\
\text { developed for this accident or renumber the foilowing subsections. } \\
\text { Follow up: section number and title added so that format is consistent with other analyses. }\end{array}$ \\
\hline
\end{tabular}


WHC-SD-WM-DRR-058 Rev. 0

This page intentionally left blank. 
WHC-SD-WM-DRR-058 Rev. 0

\section{APPENDIX D}

Check 7 ist and RCR for the Independent Technical Review of Chapter 3, Hazards and Accident Analys is 
WHC-SD-WM-DRR-058 Rev. 0

This page intentionally left blank. 


\section{CHECKLIST FOR INDEPENDENT TECHNICAL REVIEW}

DOCUMENT REVIEWED

NUMBER: WHC-SD-WM-ISB-009, Rev. 0, Chapter 3

TITLE: WESF FSAR

$\operatorname{AUTHOR}(\mathrm{s}):$ B. E. Hey

I. Method(s) of Review

( ) Input data checked for accuracy

( $X)$ Independent calculation performed

( $X)$ Hand calculation

() Alternate computer code:

( ) Comparison to experiment or previous results

() Alternate method (define)

II. Checklist (either check or enter NA if not applied)

(X) Task completely defined

( $X$ ) Activity consistent with task specification

( $X$ ) Necessary assumptions explicitly stated and supported

(X) Resources properly identified and referenced

( $X)$ Resource documentation appropriate for this application

(X) Input data explicitly stated

( $X$ ) Input data verified to be consistent with original source

(NA) Geometric model adequate representation of actual geometry

(X) Material properties appropriate and reasonable

(NA) Mathematical derivations checked including dimensional consistency

(NA) Hand calculations checked for errors

(X) Assumptions explicitly stated and justified

(NA) Computer software appropriate for task and used within range of validity

(NA) Use of resource outside range of established validity is justified

(NA) Software runstreams correct and consistent with results

(NA) Software output consistent with input

(X) Results consistent with applicable previous experimental or analytical findings

( $X$ ) Results and conclusions address all points and are consistent with task requirements and/or established limits or criteria

( $X)$ Conclusions consistent with analytical results and established limits

(NA) Uncertainty assesment appropriate and reasonable

() Other (define)

III. Comments:

IV. REVIEWER:

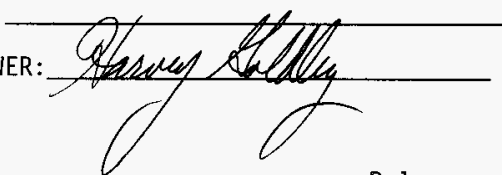

DATE: 20 Auqust 1996 
WHC-SD-WM-DRR-058 Rev. 0

This page intentionally left blank.

D-2 


\section{REVIEW COMMENT RECORD (RCR)}

\section{Date \\ 5 August 1996}

3. Project No.
2. Review No.

4. Page

1 of 5

\begin{tabular}{|c|c|c|c|c|}
\hline 5. Document Number(s)/Title(s) & $\begin{array}{l}6 . \\
\text { Program/Project/ } \\
\text { Building Number }\end{array}$ & 7. Reviewer & $\begin{array}{l}8 . \\
\text { Organization/Group }\end{array}$ & $\begin{array}{l}9 . \\
\text { Location/Phone }\end{array}$ \\
\hline WHC-SD-WM-ISB-009, Rev. 0 Chapter 3 & WESF FSAR & Harvey Goldberg & $\begin{array}{l}\text { Safety Analysis \& } \\
\text { Nuclear Engineering/ } \\
\text { Criticality \& } \\
\text { Shielding }\end{array}$ & $\begin{array}{l}825 \text { Jadwin/ } \\
376-3765\end{array}$ \\
\hline
\end{tabular}

17. Comment Submittal Approval:

10. Agreement with indicated comment disposition(s)

11. CLOSED

\begin{tabular}{|c|c|c|c|c|}
\hline \multicolumn{5}{|c|}{ Organization Manager (Optional) } \\
\hline $\begin{array}{l}12 . \\
\text { te } \\
m\end{array}$ & $\begin{array}{l}\text { 13. Comment(s)/Discrepancy(s) (Provide technical justificatioh for the } \\
\text { comment and detailed recommendation of the action required to } \\
\text { correct/resolve the discrepancy/problem indicated.) }\end{array}$ & $\begin{array}{l}14 . \\
\text { Hold } \\
\text { Point }\end{array}$ & 15. Disposition (Provide justification if NOT accepted.) & $\begin{array}{l}16 . \\
\text { Statu } \\
s\end{array}$ \\
\hline 1 & $\begin{array}{l}\text { Generally, within the text SI units are used } \\
\text { followed by older units in parentheses. However, } \\
\text { the tables are all in the older units. }\end{array}$ & & $\begin{array}{l}\text { Accepted. This will be corrected upon } \\
\text { completion of overall tech edit. }\end{array}$ & \\
\hline 2 & $\begin{array}{l}\text { P 3-9 Table 3.3.1-1: The meaning of the shading is } \\
\text { not indicated }\end{array}$ & & $\begin{array}{l}\text { Accepted. redlining has been used } \\
\text { internaliy for the preparation of the } \\
\text { document. It no longer has meaning and will } \\
\text { be removed. }\end{array}$ & \\
\hline 3 & $\begin{array}{l}\text { "Dose rates" are often given in units of } R / h r \text {. } \\
R \text { (Roentgen) is a unit of exposure, not dose. }\end{array}$ & $x$ & $\begin{array}{l}\text { Accepted. Al1 occurrences of this changed } \\
\text { to "exposure rates." }\end{array}$ & \\
\hline 4 & $\begin{array}{l}\text { When the dose results are given, it is not clear } \\
\text { what dose is used. The Effective Dose Equivalent } \\
\text { (EDE) is different than the Deep Dose Equivalent } \\
\text { (DDE). For }{ }^{137} \mathrm{Cs}-\mathrm{Ba} \text { the two are the same, but for } \\
\text { bremsstrahlung contributions (e.g. }{ }^{90} \mathrm{Sr}-\mathrm{Y} \text { ) with a } \\
\text { large low energy contribution, the difference can be } \\
\text { large. }\end{array}$ & $x$ & $\begin{array}{l}\text { In no case does Bremsstralung ever make a } \\
\text { significant contribution to the dose a } \\
\text { person would receive in any of the accidents } \\
\text { or upset conditions analyzed. For all } \\
\text { practical purposes, the DDE is the same as } \\
\text { the EDE for the exposure considered. }\end{array}$ & \\
\hline
\end{tabular}




\begin{tabular}{|l|l|l|}
\hline \multirow{2}{*}{ REVIEW COMMENT RECORD (RCR) } & $\begin{array}{c}\text { 1. Date Review No. } \\
5 \text { August } 1996\end{array}$ \\
\cline { 2 - 4 } & 3. Project No. & 4. Page \\
\hline
\end{tabular}

\begin{tabular}{|c|c|c|c|c|}
\hline $\begin{array}{l}12 . \\
\text { Ite } \\
\mathrm{m}\end{array}$ & $\begin{array}{l}\text { 13. Comment(s)/Discrepancy(s) (Provide technical justification for the } \\
\text { comment and detailed recommendation of the action required to } \\
\text { correct/ resolve the discrepancy/problem indicated.) }\end{array}$ & $\begin{array}{l}14 . \\
\text { Hold } \\
\text { Point }\end{array}$ & 15. Disposition (Provide justification if NOT accepted.) & $\begin{array}{l}16 . \\
\text { Statu } \\
s\end{array}$ \\
\hline 5 & $\begin{array}{l}\text { The release fractions on page } 3-16 \text { are not } \\
\text { referenced }\end{array}$ & & $\begin{array}{l}\text { The fractions from DOE-STD-1027-92 are } \\
\text { referenced. For the fraction released in } \\
\text { the loss of water accident the statement } \\
\text { "(out a total of } 3,546 \mathrm{~kg} \text { )" is added } \\
\text { following the stated release of } 110 \mathrm{~kg} \text {. }\end{array}$ & \\
\hline 6 & $\begin{array}{l}\text { Page 3-16: What is "TQ"? This is not defined. I } \\
\text { only have Chapter } 3 \text { and perhaps it is defined } \\
\text { elsewhere in the document. }\end{array}$ & & $\begin{array}{l}\text { TQ is "threshold quantity". Statement to } \\
\text { this effect added following equation. }\end{array}$ & \\
\hline 7 & $\begin{array}{l}\text { Footnote } 6 \text { in Table } 3.3 .2 .3-1 \text { is referenced on page } \\
3-20 \text {, but the not appears on page } 3-21 \text {. }\end{array}$ & & $\begin{array}{l}\text { Accepted. This will be corrected during the } \\
\text { overall tech edit of the chapter. }\end{array}$ & \\
\hline 8 & $\begin{array}{l}\text { There is no mention of any switching time between an } \\
\text { electrical failure and the kicking in of the standby } \\
\text { power. Is this instantaneous and, if not, what } \\
\text { effect will the delay have? }\end{array}$ & $X$ & $\begin{array}{l}\text { Accepted. Initially, the analysis in } \\
3.4 .2 .2 .1 \text { contained the actual time delays } \\
\text { and priorities for restoring power. This } \\
\text { detail was removed because it was not } \\
\text { neccessary to arrive at the conclusions and } \\
\text { could potentially be detrimental to facility } \\
\text { operations. However, some feel for the } \\
\text { delay should be conveyed and so the } \\
\text { statement "after a short delay" has been } \\
\text { added prior to "The systems supplied with } \\
\text { power..." }\end{array}$ & \\
\hline 9 & $\begin{array}{l}\text { Page 3-28: Some discussion of the }{ }^{90} \mathrm{Sr}-\mathrm{Y} \\
\text { bremsstrahlung might be in order here. While the } \\
\text { fraction of the beta-particle energy converted to } \\
\text { photons is small }(<.25 \%) \text {, the energy does go up to } \\
2.28 \mathrm{MeV} \text {. }\end{array}$ & $x$ & $\begin{array}{l}\text { Accepted. The statement is added to the } \\
\text { effect that bremsstrahlung radiation is } \\
\text { generated at the facility but that there is } \\
\text { no identified condition where it would play } \\
\text { a significant role in dose rate estimates. }\end{array}$ & \\
\hline 10 & $\begin{array}{l}\text { Page 3-28, paragraph } 4: \text { The phrase concerning the } \\
\text { inactive pools should be another sentence. }\end{array}$ & & Accepted. $\mathrm{Cl}$ ause deleted. & \\
\hline
\end{tabular}




\begin{tabular}{|l|l|l|}
\hline \multirow{2}{*}{ REVIEW COMMENT RECORD (RCR) } & $\begin{array}{c}\text { 1. Date } \\
5 \text { August } 1996\end{array}$ & 2. Review No. \\
\cline { 2 - 4 } & 3. Project No. & 4. Page \\
3 of 5
\end{tabular}

\begin{tabular}{|c|c|c|c|c|}
\hline $\begin{array}{l}12 . \\
\text { Ite } \\
m\end{array}$ & $\begin{array}{l}\text { 13. Comment(s)/Discrepancy(s) (Provide technical justification for the } \\
\text { comment and detailed recommendation of the action required to } \\
\text { correct/ resolve the discrepancy/problem indicated.) }\end{array}$ & $\begin{array}{l}14 . \\
\text { Hold } \\
\text { Point }\end{array}$ & 15. Disposition (Provide justification if NOT accepted.) & $\begin{array}{l}16 . \\
\text { Statu } \\
s\end{array}$ \\
\hline 11 & $\begin{array}{l}\text { Page 3-28, bullet 2: If the capsules are kept in } \\
\text { water, how can water leaking out of a capsule be } \\
\text { detected. I can see, however, how } C s \text { or } S r \text { can be } \\
\text { detected. }\end{array}$ & & $\begin{array}{l}\text { Bullet 2, pg. } 3-28 \text { states "A sump with leak } \\
\text { detection capabilities is provided to } \\
\text { collect any water which may leak from a } \\
\text { liner." This refers to a potential leak from } \\
\text { a liner to the under-1iner sump system which } \\
\text { has water detection capability. This is not } \\
\text { referring to water leaking from a capsule. }\end{array}$ & \\
\hline 12 & $\begin{array}{l}\text { Do the differential pressure monitors on the HEPA } \\
\text { filters alarm on low pressure as well as high } \\
\text { pressure? If not, the loss of a filter, it not } \\
\text { accompanied by contamination may not be detected. } \\
\text { Thus when an accident happens they have NO HEPA } \\
\text { filters. }\end{array}$ & $x$ & $\begin{array}{l}\text { The differential pressure system for the } K-3 \\
\text { HEPA filters is currently set to alarm on a } \\
\text { high dP only (low dP alarm is possible but } \\
\text { with the new filters the dP is so low that } \\
\text { the alarm would be on continuously). } \\
\text { However, there is an annual aerosol } \\
\text { penetration test for each bank of filters. }\end{array}$ & \\
\hline 13 & $\begin{array}{l}\text { Page 3-34: Isn't gasoline a flammable material? I } \\
\text { don't see it discussed, although the event of it's } \\
\text { burning is discussed later in the document and } \\
\text { prevention of gasoline fume buildup is mentioned in } \\
\text { Table } 3.3 .2 .3-5 \text {. }\end{array}$ & $x$ & $\begin{array}{l}\text { Accepted. Gasoline identified in } \\
\text { discussion. }\end{array}$ & \\
\hline 14 & $\begin{array}{l}\text { Page 3-35: Gasoline is also an explosive material. } \\
\text { It } s \text { consequences in these situations may by similar } \\
\text { to or be bounded by other situations, however, I } \\
\text { feel that it should be mentioned. Prevention of } \\
\text { gasol ine fume buildup is mentioned in } \\
\text { Table } 3.3 .2 .3-5 \text {. }\end{array}$ & $x$ & $\begin{array}{l}\text { Gasoline, including fumes, was appropriately } \\
\text { considered in the flammable materials } \\
\text { hazards. The FHA performed by Hughes } \\
\text { Associates did not consider the possibility } \\
\text { of a gasoline fume explosion to be } \\
\text { significant enough to identify or evaluate. }\end{array}$ & \\
\hline
\end{tabular}




\begin{tabular}{|l|l|l|}
\hline \multirow{2}{*}{ REVIEW COMMENT RECORD (RCR) } & $\begin{array}{l}\text { 1. Date Review No. } \\
5 \text { August } 1996\end{array}$ \\
\cline { 2 - 4 } & 3. Project No. & 4. Page \\
\hline
\end{tabular}

\begin{tabular}{|c|c|c|c|c|}
\hline $\begin{array}{l}12 . \\
\text { Ite } \\
m\end{array}$ & $\begin{array}{l}\text { 13. Comment(s)/Discrepancy(s) (Provide technical justification for the } \\
\text { comment and detailed recommendation of the action required to } \\
\text { correct/ resolve the discrepancy/problem indicated.) }\end{array}$ & $\begin{array}{l}14 . \\
\text { Hold } \\
\text { Point }\end{array}$ & 15. Disposition (Provide justification if NOT accepted.) & $\begin{array}{l}16 . \\
\text { Statu } \\
s\end{array}$ \\
\hline 15 & $\begin{array}{l}\text { Page 3-57 to Page 3-59: Page } 303 \text { of Meteorology and } \\
\text { Atomic Energy } 1968 \text { by Slade defines the units of } \times / Q \\
\text { as } \mathrm{m}^{-3} \text { and the units of } \psi / 0 \text { as sec } \mathrm{m}^{-3} \text {. (See me for } \\
\text { other references) Admittedly the usage of these } \\
\text { around here is rather careless, but the precise } \\
\text { usage of these quantities is something that "bugs". } \\
\text { me. }\end{array}$ & & $\begin{array}{l}\text { Lamarsh uses } X / Q \text {. PNNL uses } E / Q \text {. Usage } \\
\text { appears arbitrary with the majority of SAR } \\
\text { usage being } X / Q \text {. Since the decision appears } \\
\text { arbitrary, it would be easier to stick with } \\
x / Q \text { rather than train everyone else. }\end{array}$ & \\
\hline 16 & $\begin{array}{l}\text { Page 3-59: Up unti1 this page, the footnotes and } \\
\text { their references were numbered. Now the reference } \\
\text { is numbered, but these footnotes are not. (See al so } \\
\text { Page } 3-113 \text {, Page } 3-147 \text {, Page } 3-171 \text {, and } 3-182 \text { ) }\end{array}$ & & $\begin{array}{l}\text { Accepted. This will be corrected in the } \\
\text { overall tech edit process. }\end{array}$ & \\
\hline 17 & $\begin{array}{l}\text { Page } 3-69 \text {, first complete paragraph, } 7^{\text {th }} \text { line: "with } \\
\text { a subsequent of the inlet and outlet ducting." } \\
\text { subsequent to what? }\end{array}$ & & $\begin{array}{l}\text { The prior part of the sentence indicates } \\
\text { subsequent to "displacement of the filter } \\
\text { box". The statement now says that the filter } \\
\text { boxes are bypassed due to displacement of } \\
\text { the filter box during seismic-induced ground } \\
\text { motions. }\end{array}$ & \\
\hline 18 & $\begin{array}{l}\text { Page 3-84 and all fire discussions: Are the HEPA } \\
\text { filters fire resistant? And do they have fire } \\
\text { suppressant systems up-stream of them? Has burn } \\
\text { through been considered. This may be irrelevant } \\
\text { since it is often assumed that the HEPA filters are } \\
\text { completely compromised, however it should be } \\
\text { discussed, especially in the mitigated situation. }\end{array}$ & $x$ & $\begin{array}{l}\text { The HEPA filters are the glass-fiber type. } \\
\text { The unmitigated condition assumes they fail } \\
\text { and the mitigated condition assumes they } \\
\text { survive. Survival is based upon the } \\
\text { conclusions of the FHA. In Section } \\
3.4 .2 .3 .1 .1 \text { (hot ce1l fire scenario } \\
\text { development) text has been added to better } \\
\text { summarize the conclusions of the FHA in this } \\
\text { regard. }\end{array}$ & \\
\hline
\end{tabular}




\begin{tabular}{|c|c|c|}
\hline \multirow{2}{*}{ REVIEW COMMENT RECORD (RCR) } & $\begin{array}{l}\text { 1. Date } \\
5 \text { August } 1996\end{array}$ & 2. Review No. \\
\hline & 3. Project No. & 4. Page \\
\hline
\end{tabular}

\begin{tabular}{|c|c|c|c|c|}
\hline $\begin{array}{l}12 . \\
\text { Ite } \\
\mathrm{m}\end{array}$ & $\begin{array}{l}\text { 13. Comment(s)/Discrepancy(s) (Provide technical justification for the } \\
\text { comment and detailed recommendation of the action required to } \\
\text { correct/ resolve the discrepancy/problem indicated.) }\end{array}$ & $\begin{array}{l}14 . \\
\text { Hold } \\
\text { Point }\end{array}$ & 15. Disposition (Provide justification if NOT accepted.) & $\begin{array}{l}16 . \\
\text { Statu } \\
s\end{array}$ \\
\hline 19 & $\begin{array}{l}\text { Page } 3-85 \text { and all fire discussions: Per } \mathrm{Bq} \text { inhaled } \\
\text { strontium has a larger dose delivered to the } \\
\text { standard person than cesium. And in subsequent } \\
\text { accident analyses, the inventory of strontium seems } \\
\text { to be larger than that of cesium. However, mention } \\
\text { should be made that the release factor for cesium in } \\
\text { a fire situation is much higher that in a cold } \\
\text { situation and under certain circumstances this could } \\
\text { tilt the scales. Has this been looked into? If it } \\
\text { has, it should be stated. }\end{array}$ & $x$ & $\begin{array}{l}\text { Accepted. Statements added in the source } \\
\text { term analyses for the fire scenarios that } \\
\text { the choice of release fractions considers } \\
\text { the greater volatility of the cesium } \\
\text { chloride. }\end{array}$ & \\
\hline 20 & $\begin{array}{l}\text { Page 3-102: You use one ARF:RF for both } S r \text { and Cs, } \\
\text { but cesium is very volatile. While the use of the } \\
\text { same RARF (RARF = ARF*RF) is justified in non heated } \\
\text { (cold) situations, it is not justified in a fire } \\
\text { situation. It may not make any difference in the } \\
\text { final results, this should be mentioned in the } \\
\text { discussion. }\end{array}$ & $x$ & Accepted. See comment 19. & \\
\hline 21 & $\begin{array}{l}\text { Page 3-107: Why wouldn't the contamination on the } \\
\text { filter medium be subject to release? }\end{array}$ & $x$ & $\begin{array}{l}\text { If it were assumed that the contamination } \\
\text { were on the HEPA filters, the contamination } \\
\text { could not be postulated to be released in } \\
\text { the unmitigated condition because no forces } \\
\text { could be found to cause significant } \\
\text { dislodgement. However, if the contamination } \\
\text { were not on the filter it would be subject } \\
\text { to the same forces as postulated for the } \\
\text { exhaust duct. }\end{array}$ & \\
\hline 22 & $\begin{array}{l}\text { Page 3-118, first paragraph, last sentence: } \\
\text { "resulting in a much longer time for recovery" I } \\
\text { may be reading this wrong, and it may be what you } \\
\text { want to say, but I feel that what is meant here is } \\
\text { "resulting in a much longer time available for } \\
\text { recovery". }\end{array}$ & & Change made. & \\
\hline
\end{tabular}




\begin{tabular}{|c|l|l|}
\hline \multirow{2}{*}{ REVIEW COMMENT RECORD (RCR) } & $\begin{array}{l}\text { 1. Date Review No. } \\
5 \text { August } 1996\end{array}$ & $\begin{array}{l}\text { 2. Rage } \\
\text { 3. Project No. }\end{array}$ \\
\hline
\end{tabular}

12. 13. Comment(s)/Discrepancy(s) (Provide technical justification for the

Ite comment and detailed recommendation of the action required to

$\mathrm{m}$ correct/ resolve the discrepancy/problem indicated.)

23 Page 3-120: The average $\mathrm{B}$-particle energy for ${ }^{137} \mathrm{Cs}$ is $0.1708 \mathrm{MeV}$ (Kocher) and the average $\gamma$-ray energy for ${ }^{137 \mathrm{~m}} \mathrm{Ba}$ is $0.596 \mathrm{MeV}$. There are a few

characteristic and Auger electrons coming off, too.

24 The assumption that the B-particles on the filter don't contribute to the hydrogen production assumes

that the filters are not wet. The filtering process is largely a surface process and a completely soaked filter would result in some of the B-particle energy being deposited in water.

25 Page 3-133: The ${ }^{90} \mathrm{Sr}-\mathrm{Y}$ decay deposits $1.13 \mathrm{Mev}$ of

$B$-particle energy on the average, compared with

$0.767 \mathrm{Mev}$ of combined B-particle and $\gamma$-ray energy.

Forty sever percent may be thought of as slightly

greater. However, it does not invalidate your conclusions in this section.

26 Page 3-173: I feel that the range "<1 to 6 in/week" is weak. I would suggest "less than 6 in/week".

\begin{tabular}{|c|c|c|}
\hline $\begin{array}{l}14 . \\
\text { Hold } \\
\text { Point }\end{array}$ & 15. Disposition (Provide justification if NOT accepted.) & $\begin{array}{l}16 . \\
\text { Statu } \\
s\end{array}$ \\
\hline$x$ & $\begin{array}{l}\text { For the sake of conservatism and simplicity, } \\
\text { the analysis assumes that }{ }_{137} \mathrm{Cs} \text { decay results } \\
\text { entirely in formation of } 137 \mathrm{mBa} \text { and the } \\
\text { release of } \gamma-\text { rays. Thus, no average } \gamma-\text { ray } \\
\text { energy is used. For the } B-p a r t i c l e \text { energy, } \\
1 / 3 \text { of the peak energy of } 0.552 \mathrm{MeV} / \mathrm{dis} \text { is } \\
\text { used as a conservative approximation to the } \\
\text { decay tables. }\end{array}$ & \\
\hline \multirow[t]{3}{*}{$x$} & $\begin{array}{l}\text { The filters do not become wet in the } \\
\text { accident. The scenario development } \\
\text { indicates that the design of the filter box } \\
\text { and sump is such that the water would be } \\
\text { separated from the filter by a steel wall. }\end{array}$ & \\
\hline & Comment accepted. No change necessary. & \\
\hline & Accepted. Change made. & \\
\hline
\end{tabular}


WHC-SD-WM-DRR-058 Rev. 0

\section{APPENDIX E}

Hanford Environmental Dose Overview Panel

Review Checklist for

Radiological and Nonradiological Release Calculations 
WHC-SD-WM-DRR-058 Rev. 0

This page intentionally left blank.

$E-i j$ 


\section{HEDOP REVIEW CHECKLIST \\ for \\ Radiological and Nonradiological Release Calculations}

Document reviewed (include title or description of calculation, document number, author, and date, as applicable):

Chapter 3 of WHC-SD-WM-ISB-009 Rev 0, Waste Encapsulation and Storage Facility Interim Safety Basis, August 1996

Submitted by: B.E. Hey Date Submitted: $8 / 20 / 96$

Scope of Review: radiological dose methodology

YES NO* N/A

1. [ ] [ ] 1. A detailed technical review and approval of the environmental transport and dose calculation portion of the analysis has been performed and documented.

X [ ] [ ] 2. Detailed technical review(s) and approval(s) of scenario and release determinations have been performed and documented.

[ ] [ ] 3. HEDOP-approved code(s) were used.

[ ] [ ] 4 4. Receptor locations were selected according to HEDOP recommendations.

[ [ ] [ ] 5. All applicable environmental pathways and code options were

included and are appropriate for the calculations.

4 [ ] [ 6. Hanford site data were used.

[ ] [ ] 4 . Model adjustments external to the computer program were justified and performed correctly.

4 [ ] [ ] 8. The analysis is consistent with HEDOP recommendations.

[] [4 9. Supporting notes, calculations, comments, comment resolutions, or other information is attached. (Use the "Page 1 of $X$ " page numbering format and sign and date each added page.)

L] [ ] 10. Approval is granted on behalf of the Hanford Environmental Dose Overview Panel.

* A11 "NO" responses must be explained and use of nonstandard methods justified.

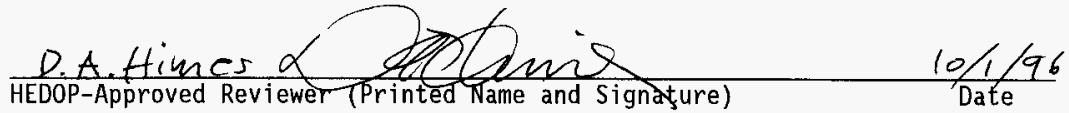

COMMENTS (add additional signed and dated pages if necessary): 
WHC-SD-WM-DRR-058 Rev. 0

This page intentionally left blank. 
WHC-SD-WM-DRR-058 Rev. 0

\author{
APPENDIX $F$ \\ Safety and Environmental Advisory Counci1, \\ Transition Facility Subcouncil \\ Review RCRs
}


WHC-SD-WM-DRR-058 Rev. 0

This page intentionally left blank. 


\begin{tabular}{|l|l|l|l|}
\hline \multirow{2}{*}{ REVIEW COMMENT RECORD (RCR) } & $\begin{array}{l}\text { 1. Date } \\
\text { August 29, 1996 }\end{array}$ & $\begin{array}{l}\text { 2. Review No. } \\
\text { SEAC-96-004 }\end{array}$ \\
\cline { 2 - 3 } & $\begin{array}{lll}\text { 3. Project No. } \\
\text { N/A }\end{array}$ & $\begin{array}{l}4 . \text { Page } \\
1 \text { of } 4\end{array}$ \\
\hline
\end{tabular}

\begin{tabular}{|c|c|c|c|c|}
\hline $\begin{array}{l}\text { 5. Document Number(s)/Title(s) } \\
\text { WHC-SD-WM-ISB-009 }\end{array}$ & $\begin{array}{l}\text { 6. Program/Project/ } \\
\text { Building Number } \\
\text { WESF }\end{array}$ & $\begin{array}{l}\text { 7. Reviewer } \\
\text { D. M. Busche }\end{array}$ & $\begin{array}{l}\text { 8. Orgenization/Group } \\
\text { SEAC Subcouncil }\end{array}$ & $\begin{array}{l}\text { 9. Location/Phone } \\
703 \text { Bui lding/Rm } 225 \\
376-9593\end{array}$ \\
\hline
\end{tabular}

17. Comsnent Subnittal Approval:

Organization Manager (Optional)
10. Agreement with indjcated comment disposition(s)<smiles></smiles>
7 urdaches $9-24-96$ Reviewer/Point of Contact

Organization Manager (Optional) Deviewer/Point of Contact

11. CLOSED

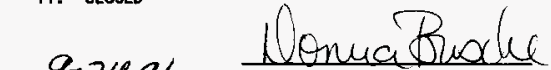
$9-24-96$ Reyiewer/Point of Contact Ser/point of contact

\begin{tabular}{|c|c|c|c|c|}
\hline $\begin{array}{l}12 . \\
\text { I tem }\end{array}$ & $\begin{array}{l}\text { 13. Comment(s)/Discrepancy(s) (Provide technical justification for the } \\
\text { comment and detailed reconmendation of the action required to correct/ } \\
\text { resolve the discrepancy/problem indicated.) }\end{array}$ & $\begin{array}{l}14 . \\
\text { Hold } \\
\text { Point }\end{array}$ & 15. Disposition (Provide justification if nOT accepted.) & $\begin{array}{l}16 . \\
\text { Status }\end{array}$ \\
\hline 1 & $\begin{array}{l}\text { (General) The text of the document uses the term } \\
\text { TECHNICAL SAFETY REQUIREMENT in several places. } \\
\text { Recommend having tech editing search and replace as } \\
\text { appropriate. No response required. }\end{array}$ & & $\begin{array}{l}\text { Technical Safety Requirements will be } \\
\text { changed to be Interim Operational Safety } \\
\text { Requirements (typo). }\end{array}$ & C \\
\hline 2 & $\begin{array}{l}\text { (Section 1.4) Recommend moving to the transmittal } \\
\text { letter. This section will be IRRELEVANT as soon as } \\
\text { the document is approved by DOE and line management } \\
\text { begins to implement. No response required. }\end{array}$ & & $\begin{array}{l}\text { Agree, Section } 1.4 \text { has been deleted from the } \\
\text { BIO. }\end{array}$ & C \\
\hline 3 & $\begin{array}{l}\text { (Table 1-1) B Plant/WESF has ONE emergency plan. } \\
\text { The discussion here and later in the text addressing } \\
\text { impact from adjacent facilities should identify the } \\
\text { tie. In nuclear safety commitment space, the two } \\
\text { facilities are linked by this administrative } \\
\text { commitment. No response required. }\end{array}$ & & $\begin{array}{l}\text { Table 1-1 has been deleted, therefore, this } \\
\text { specific comment is no longer valid. } \\
\text { Currently, WESF has several emergency } \\
\text { procedures and a few are still coupled to } \\
\text { B Plant. Impacts from adjacent B Plant are } \\
\text { identified in Section } 3.4 .2 .2 .2 \text { as is the } \\
\text { common emergency response system. Chapter } \\
6.0 \text { "Safety Related Programs and Controls," } \\
\text { Section } 6.5 \text { discusses WESF emergency } \\
\text { preparedness and includes any B Plant } \\
\text { interfaces, i.e., emergency communication } \\
\text { equipment. }\end{array}$ & C \\
\hline
\end{tabular}




\begin{tabular}{|c|c|c|}
\hline REYIFUI COMMENT RECORD IRCRI & $\begin{array}{l}\text { 1. Date } \\
\text { August 29, } 1996\end{array}$ & $\begin{array}{l}\text { 2. Review No. } \\
\text { SEAC-96-004 }\end{array}$ \\
\hline REVIEV LUIVIVIEIVI RECURD (RCK) & $\begin{array}{r}\text { 3. Project No. } \\
\text { N/A }\end{array}$ & $\begin{array}{l}\text { 4. Page } \\
2 \text { of } 4\end{array}$ \\
\hline
\end{tabular}

\begin{tabular}{|c|c|c|c|c|}
\hline $\begin{array}{l}12 . \\
\text { I tem }\end{array}$ & $\begin{array}{l}\text { 13. Comment(s)/Discrepancy(s) (Provide technical justification for the } \\
\text { corment and detailed recomendation of the action required to correct/ } \\
\text { resolve the discrepancy/problem indicated.) }\end{array}$ & $\begin{array}{l}14 . \\
\text { Hoid } \\
\text { Point }\end{array}$ & 15. Disposition (Provide justification if MOT accepted.) & $\begin{array}{l}16 . \\
\text { Status }\end{array}$ \\
\hline 4 & $\begin{array}{l}\text { (Section } 2.6 .1 .3) \text { Last sentence --- clarify WHAT } \\
\text { criteria that the K-3 ventilation system filter } \\
\text { houses are qualified. }\end{array}$ & $\mathrm{dmb}$ & $\begin{array}{l}\text { Only the pit and duct are seismically } \\
\text { qualified; the filter housing is not. The } \\
\text { following sentence was added to the } \\
\text { description "The K-3 filter housing is not } \\
\text { seismically anchored within the pit." }\end{array}$ & C \\
\hline 5 & $\begin{array}{l}\text { (Section } 3.3 .2 .2) \text { Hazard Classification pg } 3-22 \text {. } \\
\text { Delete discussion on HCl. This is a DOE action in } \\
\text { accordance with the referenced standard. See } \\
\text { recommended red-line markup attached to DSI. }\end{array}$ & $d m b$ & $\begin{array}{l}\text { There is some confusion surrounding the } \\
\text { hazard categorization of the WESF because of } \\
\text { past safety analyses and the distinction } \\
\text { between a "preliminary" and a "final" hazard } \\
\text { category. To alleviate the confusion it was } \\
\text { decided to identify all of the pertinent } \\
\text { information and to reiterate, since much of } \\
\text { the information is new (i.e., presented for } \\
\text { the first time in the BI0), the guidance } \\
\text { from the referenced Standard. The following } \\
\text { sentence has been deleted, "The facility is } \\
\text { designated as Hazard Category 1, if, as DoE- } \\
\text { STD-1027-92 states, "The Hazard Analysis } \\
\text { shows the potential for significant off-site } \\
\text { consequences." }\end{array}$ & C \\
\hline 6 & (Section 3.3.2.3.1) DELETE this section. & $\mathrm{dmb}$ & $\begin{array}{l}\text { WESF is contractually obligated to follow } \\
\text { DOE Order } 5480.23 \text { and its implementing } \\
\text { guidance document, DOE-STD-3009-94. The } \\
\text { Standard indicates that a discussion of } \\
\text { planned operation and safety improvements } \\
\text { must be made. There, lacking any other DOE } \\
\text { guidance to the contrary, a discussion is } \\
\text { presented of future activities which might } \\
\text { play a role in the safety of the facility. } \\
\text { If the postulated activities are canceled or } \\
\text { altered, the SAR (and future updates) will } \\
\text { reflect the new status of the activity or } \\
\text { delete it entirely, as appropriate. }\end{array}$ & C \\
\hline
\end{tabular}




\begin{tabular}{|l|l|l|l|}
\hline \multirow{2}{*}{ REVIEW COMMENT RECORD (RCR) } & $\begin{array}{l}\text { 1. Date } \\
\text { August 29, 1996 }\end{array}$ & $\begin{array}{c}\text { 2. Review Mo. } \\
\text { SEAC-96-004 }\end{array}$ \\
\cline { 2 - 3 } & $\begin{array}{l}3 . \text { Project Mo. } \\
\text { N/A }\end{array}$ & $\begin{array}{l}4 . \text { Page } \\
3\end{array}$ \\
\hline
\end{tabular}

\begin{tabular}{|c|c|c|c|c|}
\hline $\begin{array}{l}12 . \\
\text { I tem }\end{array}$ & $\begin{array}{l}\text { 13. Comment(s)/Discrepancy(s) (Provide technical justification for the } \\
\text { comment and detailed recommendation of the action required to correct/ } \\
\text { resolve the discrepancy/problem indicated.) }\end{array}$ & $\begin{array}{l}\text { 14. } \\
\text { Hoid } \\
\text { Point } \\
\end{array}$ & 15. Disposition (Provide justification if Nor accepted.) & $\begin{array}{l}16 . \\
\text { Status }\end{array}$ \\
\hline 7 & $\begin{array}{l}\text { (Section } 3 \text { general) Strongly recommend that all } \\
\text { discussion of beyond design basis be deleted. }\end{array}$ & & $\begin{array}{l}\text { DOE-STD-3009-94 clearly indicates the need } \\
\text { to discuss beyond design basis events. No } \\
\text { deviation from the Standard has been sought. }\end{array}$ & C \\
\hline 8 & $\begin{array}{l}\text { (Tables } 3-13 \text { and } 3-14) \text { Building wake factor was } \\
\text { applied to the } X / Q \text { for the onsite receptor. The } \\
\text { identified reference indicates the adjustment factor } \\
\text { is valid for LoNG durations. Onsite durations are } \\
\text { typically for acute situations. Provide appropriate } \\
\text { reference for adjustment factor or revise. }\end{array}$ & $\mathrm{dmb}$ & $\begin{array}{l}\text { The text associated with the tables } \\
\text { indicates that building wake is used and } \\
\text { that for extended releases building wake AND } \\
\text { plume meander are both appropriate. } \\
\text { Building wake itself is always appropriate } \\
\text { provided that the basic facility structure } \\
\text { is assumed to survive the postulated } \\
\text { accident conditions. }\end{array}$ & C \\
\hline 9 & $\begin{array}{l}\text { (Section } 3.4 .1 .3 \text { ) This section needs additional } \\
\text { clarification to distinguish between the risk } \\
\text { acceptance guidelines and the SC/SSC criteria. The } \\
\text { are NOT one in the same and have different purposes. }\end{array}$ & $\mathrm{dmb}$ & $\begin{array}{l}\text { The following points have been added to the } \\
\text { subject discussion in Section } 3.4 .1 \text {, } \\
\text { Methodology: For safety classification the } \\
\text { EGs used are from } 4-46 \text {, Chapter } 9 \text { and } \\
\text { pertain to the designation of equipment (and } \\
\text { associated IOSRs) only. The EGs used for } \\
\text { risk acceptance and designation of IOSRs not } \\
\text { associated with hardware are taken from } \\
\text { WHC-CM-4-46, Chapter 7. Although having } \\
\text { different sources and uses, the EGs are } \\
\text { numerically the same. }\end{array}$ & C \\
\hline 10 & (Section 4.0) No significant comments. & & No response required. & C \\
\hline
\end{tabular}




\begin{tabular}{|c|l|l|l|}
\hline \multirow{2}{*}{ REVIEW COMMENT RECORD (RCR) } & $\begin{array}{l}\text { 1. Date } \\
\text { August 29, 1996 }\end{array}$ & $\begin{array}{l}\text { 2. Review No. } \\
\text { SEAC-96-004 }\end{array}$ \\
\cline { 2 - 3 } & $\begin{array}{l}3 . \\
\text { Project No. } \\
\text { N/A }\end{array}$ & $\begin{array}{l}4 . \text { Page } \\
4 \text { of } 4\end{array}$ \\
\hline
\end{tabular}

\begin{tabular}{|c|c|c|c|c|}
\hline $\begin{array}{l}12 . \\
\text { I tem }\end{array}$ & $\begin{array}{l}\text { 13. Comment(s)/oiscrepancy(s) (Provide technical justification for the } \\
\text { comment and detailed recomnendation of the action required to correct/ } \\
\text { resolve the discrepancy/problem indicated.) }\end{array}$ & $\begin{array}{l}\text { 14. } \\
\text { Hold } \\
\text { Point }\end{array}$ & 15. Disposition (Provide justification if NOT accepted.) & $\begin{array}{l}16 . \\
\text { status }\end{array}$ \\
\hline 11 & $\begin{array}{l}\text { (Section 5.0) Only cursory review. Need to see the } \\
\text { IOSR document. Initially concerns are the apparent } \\
\text { selection of ACs to : } \\
\text { - address waste acceptance criteria at solid waste } \\
\text { facilities based on ENVIRONMENTAL regulations } \\
\text { - mandate the USQ process }\end{array}$ & & $\begin{array}{l}\text { Chapter } 5.0 \text {, Section } 5.7 .2 \text {, "Facilities } \\
\text { Affected By the WESF Safety Basis," will be } \\
\text { deleted since acceptance of waste or } \\
\text { radioactive material from WESF at other } \\
\text { facilities is a nuclear safety issue at the } \\
\text { other facilities, not at WESF. It should be } \\
\text { noted that the acceptance of waste at Sol id } \\
\text { Waste facilitties is an IOSR level control } \\
\text { for nuclear safety reasons in addition to } \\
\text { environmental reasons. } \\
\text { Chapter } 5.0 \text {, Table 5-1 (Hot Cell Fire) and } \\
\text { Table } 5-2 \text { (Chapter } 6 \text {, Safety Related } \\
\text { Programs and Controls): Reference to the } \\
\text { USQ process will be deleted so that it is } \\
\text { clear that the USQ process is not receiving } \\
\text { TSR coverage because it is not required. } \\
\text { Additionally, in the TSR document, Section } \\
5.8 \text {.1 will delete reference to the USQ } \\
\text { process and will be reworded to state: "A } \\
\text { program shall be established, implemented, } \\
\text { and maintained to ensure that the initial } \\
\text { conditions assumed in the accident analyses } \\
\text { will not be exceeded without additional } \\
\text { analyses." }\end{array}$ & C \\
\hline
\end{tabular}




\begin{tabular}{|c|c|c|c|c|c|}
\hline \multicolumn{6}{|c|}{ DISTRIBUTION SHEET } \\
\hline To & \multirow{2}{*}{\multicolumn{3}{|c|}{$\begin{array}{l}\text { From } \\
\text { L. I. Covey, BWHC }\end{array}$}} & \multicolumn{2}{|l|}{ Page 1 of 1} \\
\hline Distribution & & & & \multicolumn{2}{|c|}{ Date $10 / 15 / 96$} \\
\hline \multicolumn{4}{|l|}{ Project Title/Work Order } & \multicolumn{2}{|c|}{ EDT No. 616276} \\
\hline \multicolumn{4}{|c|}{$\begin{array}{l}\text { Waste Encapsulation and Storage Facility Basis for Interim } \\
\text { Operation and Interim Operational Safety Requirements WHC } \\
\text { Functional Review Report/KW4C5 }\end{array}$} & \multicolumn{2}{|c|}{ ECN No. $\quad N / A$} \\
\hline Name & MSIN & $\begin{array}{l}\text { Text } \\
\text { With All } \\
\text { Attach. }\end{array}$ & Text Only & $\begin{array}{l}\text { Attach./ } \\
\text { Appendix } \\
\text { Only }\end{array}$ & $\begin{array}{l}\text { EDT/ECN } \\
\text { Only }\end{array}$ \\
\hline $\begin{array}{l}\text { Covey, L. I. } \\
\text { Jennings-Mills, K. A. } \\
\text { Rau, A. B. (2 each) } \\
\text { Central Files (Original + copy) }\end{array}$ & $\begin{array}{l}S 6-51 \\
S 6-51 \\
A 2-25 \\
A 3-88\end{array}$ & $\begin{array}{l}x \\
x \\
x \\
x\end{array}$ & & & \\
\hline
\end{tabular}

